\title{
WestVirginiaUniversity
}

THE RESEARCH REPOSITORY @ WVU

Graduate Theses, Dissertations, and Problem Reports

2002

\section{Forced labor and humanitarian ideology in Kenya, 1911-1925}

Opolot James Okia

West Virginia University

Follow this and additional works at: https://researchrepository.wvu.edu/etd

\section{Recommended Citation}

Okia, Opolot James, "Forced labor and humanitarian ideology in Kenya, 1911--1925" (2002). Graduate Theses, Dissertations, and Problem Reports. 2427.

https://researchrepository.wvu.edu/etd/2427

This Dissertation is protected by copyright and/or related rights. It has been brought to you by the The Research Repository @ WVU with permission from the rights-holder(s). You are free to use this Dissertation in any way that is permitted by the copyright and related rights legislation that applies to your use. For other uses you must obtain permission from the rights-holder(s) directly, unless additional rights are indicated by a Creative Commons license in the record and/ or on the work itself. This Dissertation has been accepted for inclusion in WVU Graduate Theses, Dissertations, and Problem Reports collection by an authorized administrator of The Research Repository @ WVU.

For more information, please contact researchrepository@mail.wvu.edu. 


\title{
Forced Labor and Humanitarian Ideology in Kenya, 1911-1925
}

\author{
Opolot Okia
}

\author{
Dissertation submitted to the: \\ Eberly College of Arts and Sciences \\ at West Virginia University \\ in partial fulfilment of the requirements \\ for the degree of \\ Doctor of Philosophy \\ in \\ History
}
Robert M. Maxon, Ph.D., Chair
Steve Zdatny, Ph.D.
Amos J. Beyan, Ph.D.
Rodger Yeager, Ph.D.
Katherine Bankole, Ph.D.
Department of History
Morgantown, West Virginia
2002

Keywords: Colonial Kenya, Intellectual History, Power and Ideology, Post Colonial Studies, Imperial History

Copyright 2002 Opolot Okia 


\author{
ABSTRACT \\ Forced Labor and Humanitarian Ideology in Kenya, 1911-1925 \\ Opolot Okia
}

This dissertation research examines forced labor in colonial Kenya from 1911 to 1925 and the critique of this institution from various humanitarian organizations in Britain and subsequent changes in colonial policy regarding forced labor. The theoretical ideas of contradiction and power provide the backdrop for this study and help to illuminate the relationships between forced labor, ideology and control.

The British administrators in Kenya used forced labor as a means of accumulation for the European settlers but also for the state itself. However, forced labor for European settlers impinged upon the ideals of trusteeship. Moreover, the justifications for some forms of forced labor rested upon an amorphous idea of African communal duties that was often false. This dissertation examines the contradictions of this policy.

Humanitarians criticized certain aspects of forced labor in Kenya. Certain elements of the coercive labor regime, like forced labor for private purposes and forced labor for state purposes, were described by the humanitarian lobby in Great Britain as new forms of slavery. The colonial administration in Kenya responded by extirpating forced labor for private purposes eventually curtailing forced labor for state purposes. Significantly, though, humanitarian criticism did not address "communal" forced labor for state purposes because it was deemed a continuation of traditional duties.

Consequently, the humanitarian critique of forced labor, as opposed to mitigating colonial power, instead helped to solidify colonial control in Kenya by reemphasizing the trust principle. Humanitarian criticism of forced labor in Kenya created a moral atmosphere that allowed the administration to denounce some objectionable forced labor practices, like forced labor for private purposes, while reinforcing communal labor. This strengthened the ethical power of the colonial state as a munificent apparatus working for the benefit of African progress. 


\section{PREFACE}

The idea for this dissertation came together during a seminar on East African history. I was originally drawn to the activities of the Anti Slavery and Aborigines Protection Society regarding the issue forced labor in colonial Kenya in 1914. As a vestige of the anti slavery movement of the late $18^{\text {th }}$ early $19^{\text {th }}$ century in England, their activities against colonial policy relating to forced labor intrigued me as an embodiment of their traditional anti slavery role. Even before the forced labor controversies of the early twentieth century, humanitarian groups like the British and Foreign Anti Slavery Society had been protesting against British policy pertaining to the East African slave trade and slavery in Britain's East African Protectorate since the late nineteenth century. The issue then of anti slavery and free labor was at the heart of humanitarian concern with forced labor under the British flag and subsequently honed my initial research questions.

However, as I waded through the archives of the various humanitarian groups and the colonial office records, I reached a point where the documents met. They were conveying similar information and, on the surface, leading me no further. But, there was a conspicuous silence or for that matter agreement on one problem. The question of communal forced labor was a lacunae in both the archives. In rereading the texts, the agreement on communal labor highlighted that it was a mild almost essential form of forced labor, purely an extension of traditional duties.

This finding led me to question the previous assumptions laid forth by historians of imperial relations between Kenya and the metropole and the humanitarian lobby concerning the forced 
labor issue and in general the whole question of the progressive nature of colonial rule in Kenya. Older colonial historiography of Kenya emphasized the progressive nature of colonial rule and the ameliorative impact of the humanitarian lobby. Later scholarship contradicted this older viewpoint of the humanitarian lobby as a powerful interest group strong enough to influence colonial policy. With a recognition of communal forced labor, this dissertation, ironically, returns to the older position but interpreted in a different way.

Relying mainly upon humanitarian records and Colonial Office records, we posit that humanitarian initiative was not as essential in directly influencing the Colonial Office regarding forced labor issue. However, it was instrumental in creating a moral climate that influenced the course that the $\mathrm{CO}$ took regarding forced labor. Furthermore, the silence on communal labor in both the $\mathrm{CO}$ and humanitarian archives indicates that the impact of humanitarian initiative coupled with the response from the $\mathrm{CO}$ resulted in a normalization of forced labor under the rubric of community. The colonial state, which previous historians had described as progressive because it responded to humanitarian outcries over abuses, was in reality exploiting Africans even more through communal forced labor. In response to the outcry over forced labor, the state would proscribe and disavow certain forms of forced labor but would retain communal forced labor justified in the interests of the African community.

As in any work of "art," the dissertation is a constituted process that reflects the myriad inputs of more than the author. First of all, I give credit to my dissertation advisor, Professor Robert Maxon. His kindness and patience have been instrumental in allowing my the space to grow as a scholar and complete this project since the many years ago when I first arrived on the doorstep of the Department of History. His attention to detail, expertise and advice were very 
important in helping me avoid pitfalls along the way. The members of my committee have equally been important in honing the scope of this dissertation. Professor Robert Yeager's African politics courses helped me in conceptualizing the importance of the state in using forced labor. Dr. Amos Beyan's courses on the trans-Atlantic slave trade fashioned my interest in bonded labor in all its forms. Dr. Steven Zdatny's course on European social history introduced me to some key theoretical concepts in social history. I would also like to extend a special thank you to Dr. Katherine Bankole for agreeing to join my committee at the latter stage.

Research for this manuscript was conducted at the School of Oriental and African Studies in London, University of Birmingham Library in Birmingham, Rhodes House Library in Oxford and Syracuse University Library. Consequently, I would like to thank the Department of Social Justice at West Virginia University for receiving a doctoral fellowship during my tenure at West Virginia University and for funding my research trips to England and Syracuse. In particular, I would like to thank the present director of Social Justice, Jennifer McIntosh and the previous director, Dr. Nithi Sivanneri, for supporting me. A dissertation fellowship from Ohio University was also very helpful in allowing me to do further research and to begin writing. Consequently, I would like to thank the Dean's Office at Ohio University and Dr. Stephen Howard, the head of the Department of African Studies.

A project of this magnitude is nothing without the loving support of family. I would like to dedicate this dissertation to my parents. I especially thank my father, Nathan Okia, for reading through the manuscript, but also for providing much needed understanding of what it takes to complete the dissertation process. I especially dedicate this dissertation to my mother, Martha Okia, who had to surrender her life before her son matriculated. My siblings, Aminat Okia, 
Zelda Okia, and Kassaja Okia have also provided timely emotional support during the process. I am also extremely grateful to Susan Oryang for providing a warm and friendly place to stay while I was in London.

To my wife, Simeon Kresge, I am extremely grateful for her patience during this process. Her enduring support has been a bedrock for me. My son, Oluka Okia, has also provided support in his own way by reminding me every day through his youthful exuberance not to forget that it is only life. 


\section{TABLE OF CONTENTS}

1. Forced Labor in Colonial Kenya and the Humanitarian Critique ................Page -1-

2. Promethean Fire: Trusteeship and Free Labor $\ldots \ldots \ldots \ldots \ldots \ldots \ldots \ldots \ldots$. Page -26-

3. Early Humanitarian Protests Against Slavery and The Slave Trade in East Africa ... Page -54-

4. Slavery in the EAP: Humanitarian Protest. .................... Page -79-

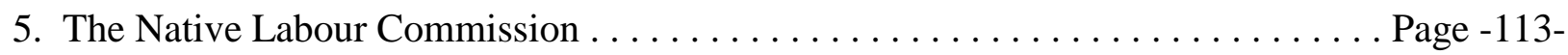

6. The Northey Crises: A Symptomatic Reading . . . . . . . . . . . . . . . Page - 160-

7. Further Labor Issues and the Normalization of Force $\ldots \ldots \ldots \ldots \ldots \ldots \ldots$ Page -235-

8. Conclusion: Furthering Communal Labor: Forced Labor as an Abstraction . . . . . . Page -280- 


\section{Chapter 1}

\section{Forced Labor in Colonial Kenya and the Humanitarian Critique}

\section{Introduction:}

This dissertation is about forced labor in early colonial Kenya and the critique of this institution from certain humanitarian groups in the United Kingdom between 1911 and 1925. The questions posed here reflect a study guided by the theoretical concepts of contradiction, power and ideology. Forced labor, trusteeship and colonial rule formed the elements of a combinatory structure in colonial Kenya which will serve as the foundation for this analysis.

The recourse to forced labor by the colonial state represented one of the myriad contradictions of colonial rule in Kenya. Humanitarian censures of the abuses of forced labor and the response from the metropolitan and colonial state were supposed to mitigate the power of the colonial rule in Kenya. However, this dissertation will examine the ways in which the discourse over forced labor actually helped to intensify colonial rule in Kenya by creating a moral atmosphere of progressive certainty around colonial labor policy. Humanitarian criticisms of forced labor and the response from the colonial state narrowed the definition of acceptable labor practices. This excluded forced labor for private purposes but, more significantly, condoned forced government labor for so called "communal" purposes. This increased the stature of the colonial state as an entity which was amenable to the concerns of its constituencies in Kenya. So, on the one hand, European settlers could be aided by cheap labor, but the state would step in to ensure the at African labor was not exploited.

In 1920 forced labor in colonial Kenya became a subject of public controversy in England. 
A labor circular ${ }^{1}$ issued by the governor of the East Africa Protectorate ${ }^{2}$, Sir Edward Northey, ignited the debate. This infamous labor circular of 1919 explicitly stated that "All government officials in charge of native areas must exercise every possible lawful influence to induce ablebodied male natives to go into the labour field." ${ }^{3}$

Criticism of the labor circular was swift but incisive. From the missionary sector in the East Africa Protectorate the two Anglican bishops of East Africa and J. W. Arthur of the Church of Scotland issued a statement criticizing the circular. ${ }^{4}$ In this criticism, which became known as the "Bishops Memorandum," the Bishops and J. W. Arthur criticized government involvement in the recruitment of forced labor for private purposes, but, significantly, they did not extend this censure to the principle of compulsion itself. Their dubious statements only inflamed the issue by admitting that some form of compulsion was necessary. ${ }^{5}$ For the bishops, the abuses associated with labor recruitment could be attributed to colonial chiefs and head men who could not distinguish between commands and hints emanating from the colonial authorities. ${ }^{6}$

Representing the humanitarian lobby, the Anti-Slavery and Aborigines Protection Society(ASAPS) and the Conference of Missionary Societies, vehemently criticized the

${ }^{1}$ Labour Circular No. 1, 23 October 1919 written over the name of the Chief Native Commissioner, John Ainsworth, by the governor of Kenya.

${ }^{2}$ The name was changed to Kenya colony in 1920 .

${ }^{3}$ Labour Circular No. 1, 23 October 1919.

${ }^{4}$ Anthony Clayton and Donald Savage, Government and Labour in Kenya, 1895-1963 (London: Frank Cass, 1974), 113.

${ }^{5}$ The "Bishops Memorandum" was thoroughly criticized by many humanitarians and was responsible for initially publicizing the issue of forced labor in colonial Kenya.

${ }^{6} \mathrm{H}$. Maynard Smith, Frank Bishop of Zanibar (New York and Toronto: The Macmilan Company, 1926), 248. 
circulars. $^{7}$ In a communique in June 1920 with Lord Milner, the Secretary of State for the

Colonies, the ASAPS issued a strong statement to the CO indicating that "encouragement" of

African labor for European plantations was not only tantamount to coercion, but this coercion

was simply slavery by another name. ${ }^{8}$

According to the ASAPS, the problem with the labor circular issued by Governor Northey

was that it contradicted an earlier statement in 1914 by the Secretary of State for the Colonies,

Lewis Harcourt, that "encouragement" of African labor by the state for private purposes was

equal to forced labor and that was, simply, slavery by another name. ${ }^{9}$ Harcourt's statement that

forced labor was tantamount to slavery had been an important coup for humanitarian

organizations like the ASAPS which had been consistently petitioning the British government to

${ }^{7}$ Kevin Patrick Grant, "A Civilized Savagery: British Humanitarian Politics and European Imperialism in Africa 1884-1920," (Ph.D. diss., University of California Berkeley, 1997), 29. The humanitarian lobby consisted of religious and social organizations such as the British Foreign and Anti-Slavery Society, the Aborigines Protection Society and the Church Missionary Society which consistently petitioned the British government to affect changes or reforms in colonial policy in the late $19^{\text {th }}$ and early $20^{\text {th }}$ century. The outlines of the humanitarian lobby were formed through a number of controversial events such as the Congo Reform Movement, the Chinese slavery controversy in South Africa and the forced labor issue in Africa in general.

8“"Labor in British East Africa: Is it Synonymous with Slavery?" Memorial to Lord Milner, 17 June 1920, Anti-Slavery and Aborigines Protection Society.

${ }^{9}$ Minute Harcourt, 15 June 1914, CO 533/148. Harcourt's statement resulted from humanitarian criticism of the Native Labour Commission report of 1912. The Native Labour Commission was convened in 1912-1913 to inquire into the labor problems in colonial Kenya. Specifically, it was commissioned to address the problems European settlers experienced in acquiring African labor. In its findings, the Commission stated that district officers in Kenya should be given specific instructions regarding "encouragement" of African labor for maximum turnout. This statement angered many humanitarian groups such as the ASAPS. The ASAPS petitioned Harcourt and he eventually acquiesced to their position, as mentioned earlier.

Page -3- 
end all forms of "slavery" in Kenya since the assumption of colonial control. ${ }^{10}$

Harcourt's agreement with the ASAPS also became a bane for the Colonial Office. For, in future controversies over forced labor, like the Northey circulars, humanitarian organizations would return to Harcourt's statement as a sacred point of reference. Harcourt's pronouncement on forced labor, besides conceding the humanitarian position that forced labor for private purposes was tantamount to slavery and, therefore, was morally wrong, also represented the ideal position of trusteeship. ${ }^{11}$

The 1919-20 protest thus emphasized trusteeship and moral force. This was made clear when humanitarian pressure upon the Colonial Office forced a parliamentary debate in the House of Lords on 14 July 1920. This resulted in a diplomatic restatement of the official position on the labor circulars by the Secretary of State. A few months later, a deputation organized by the secretary of the International Missionary Council in Great Britain and Ireland, J. H. Oldham met Lord Milner and implored the Secretary of State to convene a royal commission of inquiry to look into the labor problems in Kenya. ${ }^{12}$

Prior to the Lords debate, on 1 July 1920, Northey had issued a revised circular which supposedly curbed the powers of the colonial chiefs. This did not satisfy the humanitarians, however. In response to this continued dissatisfaction with the labor circulars, Lord Milner

${ }^{10}$ The ASAPS had been petitioning the British government to end slavery on the coast of Kenya since the 1880's and the East African Slave trade since the 1830's. This activity extended to other forms of "slavery" as defined by the ASAPS, such as forced labor for private purposes, when the Colonial Office assumed control of Kenya in 1905.

${ }^{11}$ Marjorie Dilley, British Policy in Kenya Colony (New York: Barnes and Noble, 1966), 134-135. This meant that the British were in Kenya to help the Africans develop, without exploitation, until they were deemed ready for self rule at some point in the future. During the interim period, the British had a sacred "trust" to usher the Africans towards "civilization."

${ }^{12}$ The deputation included such people as Randall Davidson, the Archbishop of Canterbury, and the Marquesse of Salisbury.

$$
\text { Page -4- }
$$


issued a despatch to the governor on 22 July 1920. Although not completely disavowing forced labor, the despatch stated that the Colonial Office rejected compulsory labor for private purposes but favored encouragement of labor in the form of advice. ${ }^{13}$ In addition, the CO also supported compulsory labor for government purposes for work of a public nature. This included the building of bridges, railways and roads. According to Milner's despatch, the $\mathrm{CO}$ also favored communal labor which included coercion of women and children on labor projects. The Secretary of State eventually resigned in 1921 but his despatch did not end the controversy. ${ }^{14}$

The new Secretary of State, Winston Churchill, was more sympathetic to the post war ideals enshrined in the League of Nations. ${ }^{15}$ Churchill clarified the Colonial Office position on coerced labor. In a despatch in September of 1921 to the administration in Kenya, Churchill upheld the principle of forced labor for government purposes but with certain limitations. ${ }^{16}$ Except for porterage, forced labor for government purposes could only be used for essential activities. Furthermore, the colonial government in Kenya would have to seek the CO's permission before using compulsory labor for government purposes. ${ }^{17}$ Conversely, the colonial state could only "encourage" African labor for private purposes through "facilitation" but not actual engagement in the procurement process of labor recruitment. ${ }^{18}$ This new direction in colonial policy did not

\section{${ }^{13}$ Clayton and Savage, Government and Labor in Kenya, 115.}

${ }^{14}$ Milner's resignation had nothing to do with the forced labor controversy in colonial Kenya.

${ }^{15}$ Clayton and Savage, Government and Labor, 117. The specific ideal I am alluding to is trusteeship.

${ }^{16}$ This later became a seminal policy paper, Parliamentary Command Paper 1509.

${ }^{17}$ Clayton and Savage, Government and Labor, 117.

${ }^{18}$ In theory, this meant that the state in Kenya was to provide information for prospective employers as opposed to actually procuring the labor for them. 
affect unpaid forced labor for traditional or communal purposes, however. ${ }^{19}$

Following another labor controversy associated with an extension of the Uganda railway, the Secretary of State for the Colonies, L. S. Amery, issued another despatch on 6 February 1925 to the Governor of Kenya, at the time Sir Robert Coryndon, which further clarified the position of the CO concerning forced labor by the administration. ${ }^{20}$ The new despatch upheld the principles of Churchill's earlier despatch and added that compulsory labor for government purposes could only be used if the Africans understood the social utility of their compulsion to work. Amery also put a cap on the number of Africans who could be compelled to work, per request by the governor, at four thousand.

Although the degree to which the state would be able to ascertain the "social utility" of a project from African informants was debatable, Amery's despatch, esssentially, put closure on the issue of forced labor. The controversy surrounding the Northey circulars and the labor circulars that preceded and followed it brought to light the philosophical conundrum of African development in a settler colony. For both the humanitarian lobby and the $\mathrm{CO}$, the fundamental question of African development was a question of the polarities of integration versus separation. Should Africans be left to develop along their own paths within their own cultural institutions, their own "community," or should they be assimilated into European culture and allowed to develop in that way?

\section{${ }^{19}$ Robert Maxon, Struggle for Kenya: The Loss and Reassertion of Imperial}

Initiative, 1912-1923 (London and Toronto: Associated University Presses, 1993), 197. This traditional unpaid labor was sanctioned under the 1912 Native Authority Ordinance and allowed a colonial chief or headman to call up labor for up to 24 days a year for duties which were considered part of the traditional duties a member of a community would have to render in the interests of the community such as upkeep of roads and clearing waterway.

${ }^{20}$ This despatch became Parliamentary Command Paper 2464 of 1925. 
Influenced by ethnographic studies and ideas of cultural pluralism, some organizations in the humanitarian lobby, like the ASAPS, emphasized land ownership and property rights for the Africans as a means of development. ${ }^{21}$ Forced labor contradicted this ideal for it pulled Africans into closer contact with European civilization in a negative way. However, communal labor, with its roots in "tribal" cohesion was less of an apparent contradiction.

Missionary groups counterbalanced this vision of African development by emphasizing acculturation of Africans with European civilization as the best means of progress. ${ }^{22}$ Forced labor, also contradicted this ideal for it represented a denouement of the paternalism inferred in acculturative development.

The $\mathrm{CO}$ and the colonial state, influenced by officials in the field, were also torn between the two paths of African development. On the one hand, administrators, like the first Chief Native Commissioner John Ainsworth, favored segregation of African production within reserves. This viewpoint emphasized "tribe" and community within Kenya and also favored African development over European agriculture as a more practical way to gain financial independence for the colony. Contrasting this vision of African development, the $\mathrm{CO}$ wavered over support for European agriculture. According to Bruce Berman, the state in Kenya was both a reflection of the institutions that encompassed the contradictions of the political economy as well as a force that shaped these institutions. ${ }^{23}$ As an institution, the state ensured its legitimacy by appearing to be an impersonal arbitrator of the conflicts and contradictions within the political economy of Kenya. Forced labor for private purposes weakened the colonial state by challenging its

\footnotetext{
${ }^{21}$ Grant, “A Civilized Savagery,” 29.

${ }^{22}$ Ibid.

${ }^{23}$ Bruce Berman, Control and Crises in Colonial Kenya (Athens: Ohio University,
} 1991), 9 
legitimacy as an impartial, institutional arbiter of the various constituencies within Kenya.

However, support for communal forced labor was an affirmation of "community" and, therefore, strengthened the power of the colonial state as an institutional structure that worked for the interests of Africans.

This research project examines the discourse surrounding these and other issues which marked the forced labor crisis in colonial Kenya and the subsequent impact of the humanitarian lobby upon colonial policy. It is our contention that far from ameliorating forced labor in colonial Kenya, humanitarian pressure had the effect of sanctioning other forms of forced labor which were deemed less objectionable. We do not contend, however, that humanitarian opposition to forced labor directly led to changes in colonial policy. Instead, we assert that humanitarian pressure helped to create a climate of moral certainty which made the shift, by the $\mathrm{CO}$ and the colonial state, to other forms of labor conscription more acceptable. This dissertation will try to examine the hidden interstices in the discourse surrounding forced labor and provide a "symptomatic" 24 reading of the humanitarian rhetoric and colonial labor policy. Utilizing the conceptual framework of "contradiction" employed by Bruce Berman and John Lonsdale, we examine the inherent contradictions of colonial policy regarding forced labor as well as the latent contradictions of the humanitarian critique of forced labor in Kenya. ${ }^{25}$

${ }^{24}$ Louis Althusser and Etienne Balibar, Reading Capital (New York: Pantheon Books, 1970), 28. For Althusser, a symptomatic reading divulges the undivulged event in the text. Basically, the question or questions which were not posed by the discourse over forced labor but which lay in the backdrop conditioning the debate.

${ }^{25}$ John Lonsdale and Bruce Berman, "Coping With Contradictions: The Development of the Colonial State in Kenya 1895-1914," in John Lonsdale and Bruce Berman, Unhappy Valley: Conflict in Kenya and Africa, Book One: State and Class (Athens: Ohio University Press, 1992), 77-100. John Lonsdale and Bruce Berman have elaborated upon this theme of contradiction in their work which deals the semi-autonomous state in Kenya. As Frederick Cooper has mentioned, the strength of the concept of contradiction as it applies to an analysis of 


\section{The Concept of Contradiction}

As Berman and Lonsdale have written, the colonial state in Kenya embodied many contradictions as it tried to shepherd the articulation of capitalism with pre capitalist social formations. ${ }^{26}$ In its attempt to maintain "relative autonomy" the state mediated two opposing modes of production (settler and peasant) within Kenya. ${ }^{27}$

The state actually straddled two levels of articulation, ${ }^{28}$ between the metropole and the colony and, within the colony, between settler production and peasant production. ${ }^{29}$ The state did not act mainly in the interests of metropolitan capital nor did it act solely on behalf of the European

the colonial state in Kenya is that this approach emphasizes the the ebb and flow of colonial attempts to continually redifne the colonial mission in the face of episodic problems. Frederick Cooper and Anne Stoler, Tensions of Empire: Colonial Cultures in a Bourgeois World (Berkeley: University of California Press, 1997), 20.

${ }^{26}$ Paul Hindess and Barry Hirst Pre-Capitalist Modes of Production (London: Routledge and Kegan Paul, 1975), 65. They were pre-capitalist social formations because power and status within society were accrued according to lineage or kinship ties as opposed to economic determinants. A mode of production is the product of the relations of production, forces of production and political and ideological relations. For Stichter the pre dominant mode of production in pre-colonial Africa is the so called lineage mode of production. However, the problem with this categorization is that it does not provide adequate illumination of the impact of long distance trade and increasing social differentiation not according to kinship ties but economic determinants. Sharon Stichter, Migrant Labor in Kenya: Capitalism and African Response, 1895-1975 (Harlow Essex: Longman, 1982), 2.

${ }^{27}$ Lonsdale and Berman, "The Crises of Accumulation, Coercion and the Colonial State," 103-104.

${ }^{28}$ Articulation describes the process where pre-capitalist modes of production are penetrated by capital. This relationship is described as articulation because initially the precapitalist forms are in a sense co-opted and utilized by capitalist development. This becomes a mode of production of itself. At this point capital cannot survive without these pre-capitalist modes of production. The culmination of this articulation does not presuppose the extinction of pre-capitalis modes of production, however. According to Sharon Stichter, articulation refers to the adaptation of capital with pre capitalist forms where the pre-capitalist mode of production preserved and recast as an appendage of capital. Stichter, Migrant Labour, 27-8.

${ }^{29}$ Lonsdale and Berman, "The Crises of Accumulation," 104. 
settlers. ${ }^{30}$ It had to maneuver between autonomy and dependency in regards to its constituencies.

As a result, the autonomy of the colonial state was continually contested on many levels by differing groups, hence the contradictions of colonial rule.

Within the metropole, two main entities influenced the colonial state in Kenya. The Colonial Office sought fiscal responsibility and a secondary adherence to the ideals of trusteeship. Humanitarian groups, on the other hand, pushed the colonial state and the $\mathrm{CO}$ to adhere to its "civilizing mission" in Kenya. ${ }^{31}$

Within the colony, European settlers bent on making Kenya, like South Africa, a "White Man's Country," ${ }^{32}$ destabilized the tenuous equilibrium of the colonial state. From the other side, indigenous political and social reaction and the accumulative interests of local peasant production sometimes placed demands upon the colonial state as well. Ultimately, the colonial state protected the interests of supplanted capitalist relations in Kenya. However, when the state compromised its autonomy in favor of the European settlers, dissent came from both the metropole and indigenous sources.

The colonial state in Kenya acted in favor of European settlers, who were economically weak

${ }^{30}$ However, since the state ultimately supported the principle of trusteeship, its adherence to African rights, for the most part, took a back seat to either settler interests or metropole interests.

${ }^{31}$ Grant, "A Civilized Savagery," 29. This "civilizing mission" related also to the concept of trusteeship as a justification for colonialism. The European colonial mission was to shepherd the Africans to higher levels of civilization. This involved, on one hand, a reliance upon Christian reform and acculturation, which, of course, had no room for perceived African cultural atavisms such as female circumcision. On the other hand, the "civilizing mission" in Africa also contained a more pluralistic vision of African development, due to the impact of ethnographic studies, which proclaimed African land rights and the right of ownership to the produce and labor of their own bodies. It was more the influence of this latter concept of trusteeship which moved humanitarian groups to protest against forced labor in colonial Kenya.

${ }^{32}$ I borrow the term from Elspeth Huxley's White Man's Country: Lord Delamere and the Making of Kenya (London: Chatto and Windus, 1935).

$$
\text { Page -10- }
$$


and undercapitalized. This damaged peasant production and the ideals of trusteeship ${ }^{33}$, and hence weakened the normalizing state. However, the states was also economically weak, itself, and utilized some forms of forced labor as subsidy. This contradiction pushed the state to utilize more coercion and force within the colonial economy which further compromised its relative autonomy. ${ }^{34}$ Forced labor was a reflection of these contradictions of the colonial state in Kenya as it attempted to corral all of the varying and diverse constituencies. Likewise, the humanitarian critique of forced labor and its surrounding discourse was the ideological extension of these contradictions of colonial rule. These ambiguities and contradictions surfaced in the aforementioned labor controversy of 1918-1919 and in the earlier labor controversy of 1912$1914^{35}$ and embodied the problems of colonial rule in Africa.

Humanitarian pressure against forced labor in colonial Kenya was part of the moral construction of a new colonialism which was tied in with a defense of capitalism in Europe but, also, reflected the contradictions of colonial rule in Africa. ${ }^{36}$

The emancipatory discourse of free labor had been the apogee of an Enlightenment belief in progress which universalized the ideals of freedom and individuality. ${ }^{37}$ Forced labor, because it

\footnotetext{
${ }^{33}$ It damaged the ideals of trusteeship because the British, under the rubric of trusteeship, were in Kenya to help the Africans develop.

${ }^{34}$ Lonsdale and Berman, "Crises of Accumulation," 118-119.

${ }^{35}$ As noted earlier, the controversy produced the statement by the Secretary of State, Lewis Harcourt, that the CO concurred with the ASAPS that forced labor for private purposes was tantamount to slavery.

${ }^{36}$ David Brion Davis, Slavery and Human Progress (New York and Oxford: Oxford University Press, 1984), 365.

${ }^{37}$ Alice Conklin, "Colonialism and Human Rights, A Contradiction in Terms? The Case of France and West Africa, 1895-1914," American Historical Review 103(2) (1998) 422; James Walvin, Questioning Slavery (London and New York: Routledge, 1996), 162; Gyan Prakash, "Colonialism, Capitalism and the Discourse of Freedom," in Shahid Amin and Marcel Van de
} 
was likened to pre capitalist forms of labor organization such as slavery, was the antonym of progress; therefore, it had to be excluded. Since colonization rested upon the idea of Africans accruing the benefits of capitalism, and therefore progress, through wage labor, forced labor for private purposes contradicted the rhetoric concerning the beneficial effects of wage labor associated with capitalist progress. ${ }^{38}$

Humanitarian agitation against forced labor for private purposes and the states amelioration of this form of forced labor also had the effect ${ }^{39}$ of sanctioning forced labor for "communal" and state purposes. This reinforced the normative power of the colonial state, as a state built upon institutions, as viewed from the metropole, while strengthening its power to rule in Kenya through force. As mentioned earlier, communal labor also represented the limits of capital as it articulated with pre capitalist forms in Kenya Colony. ${ }^{40}$ It was the embodiment of the economic

\section{Linde, eds., Peripheral Labor Studies in the History of Partial Proletarianization}

(Cambridge: Press Syndicate of the University of Cambridge, 1997), 10; Cooper and Stoler, eds., Tensions of Empire: Colonial Culture in a Bourgeoisie World, 1.

${ }^{38}$ Grant, "Uncivilized Savagery," 29. Some humanitarian groups, particularly the ASAPS, saw land ownership, free labor and respect for contractual principles as integral components of the mission civilatrice. Free labor would quell revolution and foster Western style development.

${ }^{39}$ I am not inferring that humanitarian pressure directly lead to a change in CO policy. Instead, humanitarian pressure had the effect of creating a moral atmosphere.

${ }^{40}$ There is a great body of work on modes of production in Africa which explains that, contrary to Europe, capitalism in Africa was not able to revolutionize or overcome the precapitalist mode of production. Instead it "articulated" with the pre-capitalist form absorbing some characteristics of the pre-capitalist formation while expunging others. Geoffrey Kay, Development and Underdevelopment: A Marxist Analysis (London: Macmillan, 1975); Robin Law, "In Search of A Marxist Perspective on Pre-Colonial Tropical Africa," Journal of African History 19(3)(1978); Barry Hindess and Paul Hirst, Pre-Capitalist Modes of Production (London: Routledge and Kegan Paul, 1975); Bruce Berman and John Lonsdale, "The Development of the Labour Control System in Kenya, 1919-1929," Canadian Journal of African Studies (1)14 (1980): 37-54; Aiden Forster Carter, "The Modes of Production Debate," New Left Review 107 (1978): 47-73. 
weakness of the colonial state much like coerced labor for private purposes represented the economic weakness of the European settlers. Consequently, the state justified communal labor as an atavism of pre colonial labor obligations but recast the association. It was now an artifact of "community" aiding the state in its civilizing mission through the inculcation of a healthy work ethic.

Forced labor for private purposes became equated with slavery which was "morally" wrong. Slavery was associated with pre capitalist social formations; ${ }^{41}$ therefore, it was excluded. Forced labor for communal purposes, although nominally associated with pre capitalist forms, was coopted and recast as an appendage of reforming capitalism ${ }^{42}$ with the overriding moral sanction of benevolence residing squarely with the trusteeship aims defined by the British. So, while it seemed that the forced labor regime in colonial Kenya was being ameliorated, it was actually being intensified as the focus or justification for it shifted to customary law under the guidance of "native authority." 43

${ }^{41}$ As evidenced from the work of scholars such as Eugene Genovese, Roll Jordan Roll: The World the Slaves Made (New York: Pantheon Books, 1974) and Stanley Engleman and Robert Fogle, Time on the Cross: The Economics of American Negro Slavery (Boston: Little, Brown, 1974) slavery could also be an integral component of modern industrial capitalism. Slavery in the American South is an example.

${ }^{42}$ Stichter, Migrant Labour, 37. Stichter states that forced labor in the service of peripheral capitalism resembled pre-capitalist labour which societies would normally give to a conquering nation, the so called tributary labor. The 1912 Native Authority Ordinance sanctioned traditional unpaid labor.

${ }^{43}$ With the exception of Paul Zeleza and R. M. A. van Zwanenberg this point has not been adequately illuminated such scholars like Clayton and Savage, Government and Labor in Kenya; Sharon Stichter, Migrant Labor in Kenya: Capitalism and African Response; Dilley, British Policy in Kenya Colony; Raymond Buell, The Native Problem in Africa (New York: MacMillan Company, 1928).; Gaving Kitching, Class and Economic Change in Kenya (New Haven: Yale University Press, 1980). Zeleza, however, in his chapter "Labor Coercion and Migration," in Abebe Zageye and Shubi Shero, eds., Forced Labor and Migration (New York: Hans Zell Publishers, 1989) sees reduction in the abuses of forced labor as a reflection of the 
However, the CO's interpretation of African customary labor obligations was problematic and open to question. Churchill's despatch assumed communal labor to be an extension of indigenous labor obligations. But, as Robert Maxon has stated, the Colonial Office's understanding of traditional unpaid labor, "was based upon a completely fallacious view of the traditional history of Kenya's people." ${ }^{44}$ Communal labor was manipulated by the colonial administration as an atavistic justification for forced labor that frequently went beyond what could be construed as "customary duties" like the upkeep of bridges, railways and major road systems. $^{45}$

This manipulation of customary law was ubiquitous among colonial powers as they grappled with pre capitalist modes of production. For instance, as Sally Falk Moore points out among the Chagga in modern day Tanzania, the Germans re-framed the traditional method of age grade classification as a means of calling up corveé labor. ${ }^{46}$

Ironically, the humanitarian criticisms of the Northey Circulars, thrust the blame on the headmen whom, they asserted, were not able to distinguish between a hint and a command in carrying out orders concerning "encouragement" of African labor. ${ }^{47}$ But, headmen were the

weaknesses of forced labor itself. Consequently, the colonial state came to disavow it. R. M. A. van Zwanenberg, Colonial Capitalism and Labor In Kenya (Nairobi: East African Literature Bureau, 1975) sees the recourse to communal labor by the colonial state as a way of not raising eyebrows in the metropole since the use of communal labor did not require approval by the Secretary of State for the Colonies.

${ }^{44}$ Maxon, Struggle for Kenya, 199.

${ }^{45}$ Lord Olivier, White Capital Coloured Labour (London: Hogarth Press, 1929), 241242.

${ }^{46}$ Sally Falk Moore, Social Facts and Fabrication: "Customary" Law on Kilimanjaro, 1880-1980 (Cambridge: Cambrige University Press, 1986), 96.

${ }^{47}$ This was one of the main critiques of the Northey Circulars contained in a memorandum signed by the Bishops of Uganda and Mombasa known as the "Bishops Memorandum." 
vanguard of this "vulgarization of power" 48 in the reserves. The power of the headmen and colonial chiefs in calling out labor was located on the perimeter of colonial control. The state needed the chiefs. The ambiguity of the headmen's "orders" in culling out labor represented the precarious balancing act between the raw manipulation of power and the utilization of power through institutions by the administration in Kenya. It was a reflection of the limits of its power which was "exercised rather than possessed."

The controversy over the Northey labor circular was significant because it was microcosm of the limitations of colonial rule and the hubris of ideology. Forced labor, as a reflection of the problems of utilizing African labor in a settler colony, was a much larger indictment of progress inherent in the civilizing mission.

\section{Literature Review: Humanitarian Discourse and Forced Labor}

The impact of the humanitarian discourse upon colonial labor policy, in Kenya has been debatable. ${ }^{50}$ Previous studies have not looked critically at humanitarian discourse and the issue of forced labor within the framework of the contradictions of colonial rule. ${ }^{51}$

${ }^{48}$ John Lonsdale, “ The Conquest State, 1895-1904,” in William Ochieng, ed., A Modern History of Kenya (Nairobi and London: Evans Brothers Limited, 1989), 26. This is John Lonsdale's description of the capillary nature of colonial power as it trickled down from the top.

${ }^{49}$ Alan Sheridan, trans., Michel Foucault Discipline and Punish (New York: Vintage Books, 1979), 26. I borrow this definition from Michel Foucault. Power is described in this way to illustrate the overall effect of power and its manifested strategies. This is useful for it takes us away from description of power which posits it rigidly in one locus.

${ }^{50}$ The impact of the humanitarian lobby upon colonial labor policy following the crisis over the Northey Circulars has been overrated to some degree. However, my emphasis in this particular instance is to examine the impact of the humanitarian lobby in creating an atmosphere of moral sanction; that forced labor for private purposes was wrong.

${ }^{51}$ Dilley, British Policy in Kenya; John W. Cell, ed., By Kenya Possessed: The Correspondence of Norman Leys and J. H. Oldham 1918-1926 ( Chicago: University of Page -15- 
Raymond Buell's 1928 work, Native Problem in Africa is an early example. Buell regarded administrative policy after the Northey crisis as following ". . . a policy of complete neutrality in regards to the recruiting of labor for private purposes." 52 This perspective not only neglected official acceptance of forced labor for communal purposes and government purposes but also Churchill's official statement that the colonial government would indeed be partial as a "facilitator" of African labor for private purposes.

Marjorie Dilley’s 1937 study of British policy regarding trusteeship offers a chapter on the labor controversy in Kenya in 1919. The chapter "Labour Supply" examined the problems of labor supply in colonial Kenya, and, also, delved into the controversy surrounding the Northey Circulars of 1919. Dilley observed that the Northey Circulars simply gave an official stamp to a practice (District Commissioners recruiting for private employers) which had already been customary for some time. ${ }^{53}$ The circulars were issued to regularize the process of recruitment which up to that point had been uneven. Some District Commissioners recruited for private employers while others refrained from this practice. Dilley acknowledges that state recruitment of labor for private purposes was, therefore, a shock only to the humanitarians.

However, instead of exploring the symbolism of humanitarian shock with forced labor for private purposes, Dilley treats the labor controversy simply as an assault upon trusteeship. ${ }^{54}$ Dilley does not examine the ways in which this humanitarian shock further reinforced other forms

Chicago Press, 1976); Clayton and Savage, Government and Labour in Kenya 1895-1963; Lord Olivier, White Capital and Colored Labor; van Zwanenberg, Colonial Capitalism and Labor in Kenya; Raymond Buell, The Native Problem in Africa.

${ }^{52}$ Buell, The Native Problem in Africa, 336.

${ }^{53}$ Dilley, British Policy in Kenya, 225.

${ }^{54}$ Ibid., 227. 
of forced labor such as communal labor. Moreover, due to a lack of access to primary source materials, that would have not been available at the time, Dilley does not analyze the policy implications that resulted from the labor crises regarding forced labor.

Wilhelmina Klosterboer's 1960 work Involuntary Labor Since the Abolition of Slavery examines the 1918-1919 labor crisis in Kenya. For Klosterboer, the labor problem in Kenya was not just about coercion but, the fact that, “. . . the natives showed little inclination to work for Europeans . . ",55 Accordingly, with this culturally biased assertion, Klosterboer uncritically sees Churchill's despatch as putting an end to forced labor. ${ }^{56}$

The classic study of labor in Kenya, on the other hand. is Anthony Clayton and Donald Savage's work Government and Labor in Kenya, 1895-1963. Published in 1974, this work provides an excellent overview of labor policy during the colonial period in Kenya. Clayton and Savage do an excellent job of discussing the development of the labor system in Kenya and its attachment to force. Concerning the labor crises of 1919, Clayton and Savage give credit to the humanitarian lobby for facilitating a change in colonial labor policy but do not examine the contradictions of humanitarian pressure and colonial rule. In addition, as we shall see, the CO looked first to its own administrators for guidance and not humanitarians before moving on policy issues regarding forced labor in Kenya.

Clayton and Savage do not satisfactorily elucidate the connection between the demise of forced labor for private and state purposes and the continuance of communal labor for "traditional" purposes. Clayton and Savage follow the official justification of the administration 
in Kenya and construe communal labor as an attempt to strengthen the power of the chiefs. ${ }^{57}$ This leads them to the erroneous conclusion following the Northey circulars, that communal labor was "the milder form of compulsory labor . .."58 Communal forced labor was just as harsh as forced labor for state purposes and forced labor for private purposes. As Clayton and Savage note, themselves, communal labor was a system wrought with abuses. Women and children were frequently employed away from home and on occasion women were raped while on assignment.

Colonial Capitalism and Labour in Kenya 1919-1939 published in 1975 by R. M. A. van Zwanenberg, on the other hand, is a more specific study of migrant labor in Kenya under colonialism. Van Zwanenberg's book analyzes the methods employed to bring laborers out to market. He discusses the forced labor controversy in 1919 in two chapters of his book.

For van Zwanenberg, the problems with the Northey circulars related to the economic imperatives of the settlers and the ideological constraints of the administration and the humanitarian lobby. ${ }^{59}$ Van Zwanenberg was one of the first scholars to describe the impact of the humanitarian lobby as creating a ". . . a mood rather than a whole change of emphasis . . "60 He did not see humanitarian agitation against forced labor as a strident criticism of colonialism, itself, but, rather, as a condemnation of the misapplication of trust principles by the colonial state in Kenya. ${ }^{61}$ Van Zwanenberg credits humanitarian pressure for creating a moral atmosphere. However, he fails to make the connection between humanitarian pressure against forced labor and

\footnotetext{
${ }^{57}$ Clayton and Savage, Government and Labor in Kenya, 139.

${ }^{58}$ Ibid.

${ }^{59}$ van Zwanenberg, Colonial Capitalism and Labour in Kenya, 1919-1939, 128.

${ }^{60}$ Ibid., 132.

${ }^{61}$ Ibid.
} 
heightened institutional power of colonial rule. Consequently, van Zwanenberg comes to the conclusion that humanitarian pressure was a failure because it failed to change the hearts and minds of the administration in Kenya. ${ }^{62}$ According to van Zwanenberg, humanitarian agitation simply drove the issue of forced labor underground. Officials were quick to avoid publicity over this issue in Kenya. Consequently, they used forced labor in other sanctioned ways, such as communal labor. This misses the point and sheds light upon one of the weaknesses of van Zwanenberg's approach.

Van Zawnenberg's analysis examines the $\mathrm{CO}$ and the humanitarian lobby as separate entities instead of examining the ways in which the "separate" ideology of humanitarian pressure formed a link with the trusteeship ideals of the $\mathrm{CO}$ in regards to Kenya. In essence, he does not leave space for a conceptual analysis that encompasses the "relative autonomy" of the colonial state. Humanitarian agitation entrenched the acceptance of permissible forms of forced labor. By creating a moral atmosphere of right and wrong, it helped to define acceptable forms of forced labor versus non-acceptable forms.

In her work Migrant Labour in Kenya, Sharon Stichter, on the other hand, while noting the demise of coerced labor under the Native Authority Amendent Oridinance ${ }^{63}$ from the mid 1920's onward, fails to mention the continued use of coerced communal labor. ${ }^{64}$ Zeleza estimates that in

${ }^{62}$ Ibid., 164

${ }^{63}$ The 1912 Native Authority Ordinance was the legal foundation for state coercion of labor for state purposes. It allowed paid compulsion of Africans for 60 days a year for work of a public nature such as building bridges, roads and porterage. In addition, Africans could also be called out for 24 days a year of unpaid labor which was deemed in the interests of the community.

\footnotetext{
${ }^{64}$ Stichter, Migrant Labour, 40.
} 
the 1920 's the state called out as many as 15, 000 Africans per year. ${ }^{65}$ This casts a different light on the purported demise of force labor by the colonial state.

John Cell's 1976 work, By Kenya Possessed: The Correspondence of Norman Leys and J. H. Oldham, describes the labor crisis ignited by the Northey circulars in glowing terms as a victory for the humanitarian lobby. He states that "the forced labour campaign was a classic study in the mobilisation of public opinion. And it succeeded." ${ }^{66}$

As Robert Maxon points out this apparent victory of the humanitarian lobby, in causing a change in colonial labor policy, was, in fact, preempted more by the advice of John Ainsworth, Kenya's first Chief Native Commissioner. ${ }^{67}$

Robert Maxon's 1993 work Struggle for Kenya: The Loss and Reassertion of Imperial initiative, 1912-1923, is intrinsically a very detailed study of the "process" of the colonial state in Kenya as it grappled with the problems of autonomy relating to the $\mathrm{CO}$, the humanitarian lobby, interests of metropolitan capital, colonial officials in Britain, British MPs and elements within Kenya. Struggle for Kenya analyzes the process of CO control over Kenya by going beyond the conceptual framework of "contradiction" and looking at the actual factors and constituencies involved in this assessment of colonial rule. To his credit, Maxon is one of the first to give the impact of the humanitarian lobby a more critical revision. In contrast to Cell, Maxon is one of

${ }^{65}$ Paul Zeleza, "Dependent Capitalism and the Making of the Kenyan Working Class During the Colonial Period,” (Ph.D. diss., Dalhousie University, 1982), 113.

Oldham, 41.

${ }^{66}$ Cell, By Kenya Possessed: The Correspondence of Norman Leys and J. H.

${ }^{67}$ Robert Maxon, “The Years of Revolutionary Advance, 1920-1929,” in William Ochieng ed., A Modern History of Kenya, 1895-1980 (Nairobi and London: Evans Brothers Limited, 1989), 78. 
the first scholars to see the impact of the humanitarian lobby upon colonial policy as overblown. ${ }^{68}$ In regards to the Northey labor circular fiasco, Maxon sees the impact of humanitarian lobby as less important in influencing the $\mathrm{CO}$ than the statements from administrative officials like John Ainsworth. ${ }^{69}$ This study builds upon Struggle for Kenya to discuss the role that humanitarian ideology played as a discourse imbedded in the political economy of Kenya , the response from the state and the continuance of communal forced labor.

Beyond the specific confines of labor and colonial policy in Kenya, other scholars have looked at the wider impact of humanitarians upon colonial policy in general. Two articles by Kenneth Dike Nworah and Diane Wylie propose a "moral suasionist" argument in regards to the impact of the humanitarian lobby upon colonial policy. Nworah's article, "The Aborigines Protection Society, 1889-1909: A Pressure Group in Colonial Policy" examines the role of the Aborigines Protection Society as moral watch dog of the British colonial empire in the late $19^{\text {th }}$ century. ${ }^{70}$ His article describes the historical continuity of humanitarian agitation from the late $19^{\text {th }}$ century to the early $20^{\text {th }}$ century but does not examine the ways in which humanitarian discourse helped to add moral weight to colonialism and hence control.

Diana Wylie's 1977 article “Confrontation over Kenya: The Colonial Office and its Critics 1918-1940" is an excellent study of some of the constituencies which comprised the humanitarian lobby. ${ }^{71}$ For Wylie, the humanitarian lobby was able to create a body of pro-

\section{${ }^{68}$ Robert Maxon, Struggle for Kenya: The Loss and Reassertion of Imperial}

Initiative, 1912-1923 (London and Toronto: Associated University Presses, 1993), 27.

${ }^{69}$ Ibid., 195-197.

${ }^{70}$ Kenneth Nworah, "The Aborigines Protection Society, 1889-1909: A Pressure Group in Colonial Policy," Canadian Journal of African Studies 5(1) (1971): 79-93.

${ }^{71}$ Diane Wylie, "Confrontation over Kenya: The Colonial Office and Its Critics 19181940," Journal of African History, 18(3) (1977): 427-447. She discusses mainly Norman Leys 
African opinion which helped to exert political pressure on the Colonial Office and hold back the advances of European settler demands against the Africans in Kenya. This, however, does not shed light upon the ways in which humanitarian agitation was bounded by economic concerns for the Africans while leaving political determinants aside such as the right of Africans to rule their own country. Wylie's analysis also suffers from a rigid juxtaposition of the humanitarian lobby against the Colonial Office without, significantly, exploring factors which made their conflict more apparent than real.

On a wider level, Kevin Patrick Grant examines the relationship between the humanitarian lobby and the matriculation of anti-slavery discourse. ${ }^{72}$ His work follows the main controversies of the late $19^{\text {th }}$ and early $20^{\text {th }}$ centuries which involved British humanitarian protest against human rights abuses within the colonial dominions. Although Grant's dissertation is quite helpful in outlining the broader field of humanitarian discourse, his thesis that humanitarian agitation against forms of slavery in the $19^{\text {th }}$ century was in fact the development of a new emphasis upon human rights falls victim to the extroverted nature of his inquiry. Consequently, he does not rigorously examine the ways in which this new stress upon human rights strengthened imperialism.

\section{The Texts}

The manuscript is significant for it is a seminal examination of the policy issue of forced labor in Kenya and the impact of the humanitarian lobby through a rereading of the texts. Through a

and William MacGregor Ross.

\footnotetext{
${ }^{72}$ Kevin Patrick Grant, “A Civilised Savagery.”
} 
rereading of the texts, this study delves into the relationship between the humanitarian lobby, forced labor, trusteeship and power. This study demarcates a new path.

This research for this work is based upon archival materials in London and Oxford and Syracuse University. The Colonial Office Records, Kenya National Archives and the papers of the Anti-Slavery and Aborigines Protection, Frederick Lugard Papers, the Owen Papers and the Joint Africa Archives of the international Missionary Council and Conference of British Missionary Societies have been consulted. Periodicals are often a valuable source of primary source material. The periodicals that have been consulted are the Manchester Guardian, East African Standard, Anti-Slavery Reporter and Aborigines Friend, Contemporary Review, Times, The New Statesman and The Leader.

This study is sectioned into eight chapters. Chapter Two starts with the theme of wage labor and examines the development of British and Foreign Anti Slavery Society and the Aborigines Protection Society against the backdrop of free wage ideology. Both Societies developed with a strong "pro native" axis that evinced concerns for the treatment of aborigines by proselytizing against slavery and the slave trade. Chapters Three and Four continue on this theme with a look at the activities of the BFASS, slavery and the slave trade in East Africa. Chapter Five transitions with this emphasis on bonded labor with a brief description of the political economy of colonial Kenya and the requisite labor problems. The chapter also analyzes some of the earlier labor crises associated with forced labor in 1912 and during World War One. Chapter Six examines the controversy of the so called "Northey Crises" and delves into the issues of forced labor, trusteeship and the response from the CO. Chapter Seven looks at the aftermath of the crises, and the further continuation of communal forced labor. 


\section{Conclusion}

This study is the conjugal apparatus of three themes: forced labor, trusteeship and contradiction. Humanitarian criticisms of forced labor ultimately rested upon a concern that the utilization of forced labor weakened the trust principle in Kenya. Subsequent changes in colonial labor policy by the $\mathrm{CO}$ were also a response to this weakening of the legitimacy of the colonial regime. The response from the $\mathrm{CO}$ to the forced labor issues in 1920 strengthened the foundations of trusteeship, and by inference the ideal of colonial control, by excising some objectionable labor practices while continuing others. This meant the exclusion of forced labor for private purposes but the continuation of communal labor. Despite the apparent victory of the humanitarian lobby in the Northey crisis, Churchill's despatch, also represented the beginning of a reassertion of policy initiative in Kenya by the Colonial Office. ${ }^{73}$

As mentioned earlier, communal labor was based on a social or cultural justification. However, the administration in Kenya used the surplus capital accrued from communal labor to bolster the lagging economic power of the colonial state. This acceptance of communal labor squared with a preservationist image of trusteeship in Africa which did not look favorably upon change or modernity. ${ }^{74}$ Rapped tightly like the proverbial Masai in his blankets, the African was to be protected from the more caustic advances of capitalism, such as forced labor for private purposes, while being allowed to modernize under his own institutions like forced labor for traditional or communal purposes. But, modernization was supposed to improve the African peasant through laissez faire capitalism.

\footnotetext{
${ }^{73}$ This theme of reassertion of colonial control in Kenya is highlighted in Maxon, Struggle for Kenya.
}

${ }^{74}$ Maxon, Struggle for Kenya, 20. 
This paradoxical image of African development reflected a contradictory vision of philanthropic idealism in Africa and presaged the logical crisis of the Second Scramble in Africa following World War II. The idea of trusteeship was supposed to develop Africa, but the reality of colonialism retarded African growth essentially preserving the "man in the blanket" as a relic to be examined and understood. 
Chapter 2

\section{Promethean Fire: Trusteeship and Free Labor}

The ASAPS critique of forced labor in colonial Kenya had its theoretical origins in the birth and early development of both the Aborigines protection Society and the British and Foreign Anti Slavery Society. In geographic areas where British colonial contact rendered the indigenous inhabitants vulnerable to "civilization," humanitarian organizations like the BFASS and the APS were strident in their defense of aboriginal peoples. At their respective inceptions, both the BFASS and APS evinced concerns for "native" peoples that were driven by a desire to adhere to both the ethos of trusteeship and the concomitant benefits of free labor. This chapter juxtaposes this humanitarian concern of the BFASS and the APS against the backdrop of free labor ideology and trusteeship.

\section{The British and Foreign Anti-Slavery Society}

With the official end of slavery in British territories in 1833, British humanitarian attention turned to the problematic of former slaves in the British West Indies and the aboriginal inhabitants of British dependencies. What was to be done to protect their interests?

The emancipation act of 1833 had been the crowning glory of humanitarian activity and represented the nadir of the movement. Largely the work of Sir Thomas Fowell Buxton, the decree did not actually free slaves but established an apprenticeship period of twelve years for the former West Indies slaves. Although the decree freed children under age six automatically, slaves had to remain with their masters and were still liable for corporal punishment. A second decree in 1838 eventually freed the slaves forthwith. However, the tardy emancipation coupled with a concomitant decree stipulating protective duties for British colonial sugar was an 
indication of the serious problematic of free labor confronting the British. British sugar production, based upon recently "free" labor, was, simply, not able to compete with slave grown sugar, initially.

In the wake of the emancipation act, the "burden" of "native" protection still fell on the shoulders of the humanitarian lobby. The problematic of slavery was now embodied in the issue of what to do with their labor power in a burgeoning capitalist system. According to the ethos of trusteeship, colonial powers had a "sacred trust" to ameliorate and uplift the condition of former slaves and aborigines under imperial tutelage. For the aborigine, this meant experiencing the benefits of free labor without exploitation. For humanitarian organizations like the BFASS and the APS the virtues of free labor were an assumption. Their victory in 1833 was vindication of the efficacy of free labor over slave labor. Consequently, it only remained for them to shore up the victory through ritualized protests against slavery in all its forms. The organizations recognized that the "burdens" of native protection, free labor and trusteeship, were contested ideals that had to be won. The ritualized protests, in the form of memorials and speeches, harkened back to the methods used during the fight against the trans-Atlantic slave trade that had ultimately culminated in the decree ending the trade, on the British side, in 1807.

The end of the eighteenth century also witnessed the revival of evangelical Christianity. Consequently, many religious organizations like the Wesleyan Missionary Society, the London Missionary Society and the Church Missionary Society became concerned about the exploitation of aboriginal peoples. The Aborigines Protection and British and Foreign Anti-Slavery Societies developed out of this social milieu.

The British and Foreign Anti-Slavery Society had its beginnings in 1823. In that year William Wilberforce (1759-1833) and Sir Thomas Fowell Buxton (1786-1845) formed a 
"Committee on Slavery" to discuss the slave trade and slavery in general in British territorial possessions. ${ }^{1}$ The committee began to publish a journal, The Anti-Slavery Reporter, and eventually changed its name to "The Society for the Amelioration and Gradual Abolition of Slavery." ${ }^{2}$ Following the decree abolishing slavery in 1833, this committee ${ }^{3}$ met in Exeter Hall in London on 17 and 18 April 1839 and passed certain resolutions which became the basis for the newly organized "British and Foreign Anti-Slavery Society." Its stated focus was to continue to work for

... the universal extinction of Slavery and the Slave Trade and the Protection of the Rights and Interests of the Enfranchised population in the British possessions, and all persons captured as slaves. ${ }^{4}$

The newly formed BFASS consisted of a Central Office in London, a secretary and a committee. ${ }^{5}$ The secretary was the most important executive position, but the committee held the power to formulate and implement policies. With its main office in London, the BFASS maintained an advantageous metropolitan base which offered easy access to Parliament and the

${ }^{1}$ Guide to Papers of the British and Foreign Anti-Slavery and Aborigines Protection Society (Oxford: Rhodes House Library, 1956), 1.

${ }^{2}$ Ibid. The Anti Slavery Reporter was founded in 1825; its first editor was Zachary Macaulay. It was published twice a month.

${ }^{3}$ The most notable members of the committee consisted of T. F. Buxton, Samuel Gurney and Reverend John Young. Wilberforce died in 1833. Joseph Sturge was the leader and driving force behind the formation of the BFAS at this time. Howard Temperley, British AntiSlavery 1832-1870 (Columbia: University of South Carolina Press, 1972), 68.

${ }^{4}$ From the constitution of the British and Foreign Anti-Slavery Society, 1839; Section II in Kingsley Kenneth Dike Nworah, "Humanitarian Pressure Groups and British Attitudes Towards West Africa," (Ph.D. diss., University of London, 1966), 113.

${ }^{5}$ Temperley, British AntiSlavery, 67. 
national press in England. ${ }^{6}$ A strong network of auxiliary societies strengthened the society's provincial contacts. ${ }^{7}$ To inform the public and petition the home government, the BFASS published pamphlets and distributed memorials on certain topics.

The BFASS was a direct outgrowth of the anti slavery movement. Some of its founding members, like Joseph Sturge, Thomas Clarkson and Thomas Fowell Buxton, had been prominent in the anti slavery movement. Out of the thirty original members of the Society, only five had no prior experience in the anti slavery movement. ${ }^{8}$ The predominance of Quakers, Baptists and Methodists in the leadership of the organization was also reflection of its anti slavery roots. ${ }^{9}$ Between 1839 and 1870 almost half of the committee of the BFASS were members of the Society of Friends. ${ }^{10}$

The socioeconomic status of the members of the BFASS was also a reflection of the middle class composition of the society. ${ }^{11}$ Joseph Sturge had been the son of a farmer and later became a wealthy merchant. Samuel Gurney and T. F. Buxton were financiers and came from banking families.

The cooperative strategies developed during the campaign against the trans Atlantic slave trade would prove useful in the fledgling society's new business of "native" protection. In its

${ }^{6}$ Ibid., 66.

${ }^{7}$ For example, between 1839 and 1868 the BFASS had over 100 auxiliary societies. Ibid., 88.

${ }^{8}$ Out of the of the thirty original members, twelve had belonged to the Antislavery Committee, five to the Agency and Universal Abolition Committee and twenty to the Central Negro Emancipation Committee. Temperley, British AntiSlavery, 68.

${ }^{9}$ Temperley, British Antislavery, 68.

${ }^{10}$ Ibid.

${ }^{11}$ Ibid., 69. 
efforts to combat slavery and the slave trade on the perimeters of the British Empire, the BFASS convened conferences and was active in many issues that affected the treatment of indigenous peoples. For instance, in 1840 the BFASS convened an international anti slavery convention and in 1867 held a similar conference in Paris. The 1840 convention on slavery was convened to examine areas of slavery which the British had neglected, like slavery and the slave trade in certain Muslim countries. ${ }^{12}$ It was held over a two-week period beginning on 12 June 1840 . The BFASS sent questionnaires to the attendees before the conference which addressed different aspects of slavery in their regions. Delegates came from all over the world including prominent members of the anti slavery movement. ${ }^{13}$

The themes of the conference mainly dealt with slavery, the slave trade and emancipation; however, one aspect of the conference examined the issue of free labor. ${ }^{14}$ A Committee on Free Labour, headed by John Sturge, was formed "to collect and arrange facts on the advantages of free labour over slave labour."15 One of the reports delivered by the Committee on Free Labour cited Adam Smith in support of the viewpoint that free labor was more efficient than slave labor. ${ }^{16}$ Ultimately, the free labor component of the final resolutions of the conference reemphasized "the superior cheapness" of free labor and called for an end to the use of slave labor. At the culmination of the convention, on 23 June 1840, the attendants passed resolutions

${ }^{12}$ Ibid., 86.

${ }^{13}$ A feeble Thomas Clarkson made a token appearance. He would die on 26 September 1846. Anti-Slavery Reporter, July 1, 1840.

${ }^{14}$ British and Foreign Ant-Slavery Society, Proceedings of the General Anti-Slavery Convention (London: Thomas Ward and Company, Hamilton Adams and Company, 1841), iv-v.

\footnotetext{
${ }^{15}$ Ibid., 105.

${ }^{16}$ Ibid., 335.
} 
which re-emphasized their "moral, religious and pacific" opposition to slavery and the slave trade. $^{17}$

The slave trade convention in 1867 addressed the problem of slavery and the slave trade in a wide range of geographic regions including the use of slaves by the Boers in South Africa and the ending of the slave trade to Cuba. ${ }^{18}$ However, the 1867 Convention was significant, also, because it focused attention upon the East African slave trade. Due to the Society's contacts with the explorer David Livingstone, it became more aware of the East African slave trade and would begin to publish many of Livingstone's letters describing the East African slave trade in the Anti Slavery Reporter. In 1873 BFASS efforts vicariously resulted in Sir Bartle Frere's mission to Zanzibar to negotiate an anti slavery treaty. ${ }^{19}$ In 1875 it actually sent a deputation to Zanzibar to learn more about the machination of slavery there.

BFASS agitation against slavery and the slave trade also extended to so-called aboriginal rights and to areas where the nomenclature of slavery was more nebulous and harder to define. In the West Indies, the BFASS protested against the use of "coolie labor" by British planters. ${ }^{20}$

${ }^{17}$ Anti-Slavery Reporter, June 15, 1842. This reference to pacific means was one of the differences between the APS and BFAS. The APS condoned the use of force in combating slavery and the slave trade.

${ }^{18}$ Ibid., September 16, 1867, Boer "slavery" was in actuality the oppressive system of apprenticeship or imboeking which the Boers used to acquire African labor.

${ }^{19}$ R. W. Beachey, The East African Slave Trade, (London: Rex Collings, 1976), 223. Charles Gilpin, an MP and member of the BFASS, obtained the appointment of a Select Committee in 1871 to address the East African Slave trade. The Committee's findings resulted in Frere's mission.

${ }^{20}$ Following the abolition of slavery, British planters began importing indentured laborers from Asia. For instance, as early as early as 1834 Mauritian planters began importing laborers from India. By 1838 there were more than 25,000 Indian laborers working on the island. The laborers were usually contracted for five years. The system led to abuses which were deemed analogous to slavery by the humanitarian lobby. Temperley, British AntiSlavery, 124. 
The BFASS also lobbied against the importation of Polynesian laborers into Peru where they faced abuse. In the case of Peru, the Peruvian authorities agreed to end the traffic in 1864.

However, the main focus of the BFASS always remained slavery and the slave trade. To this end, the fledgling organization (BFASS) also sought to promote the end of slavery through the circulation of information and evidence to slave-holding nations so as

To recommend the use of free grown produce as far as practicable in preference to slave grown and to promote the adoption of fiscal regulation in favour of free labour. $^{21}$

Free labor was the crux of this humanitarian concern for aboriginal peoples. The BFASS statement on free labor reflected the Society's belief in the virtuous opposition of free labor against slave labor that progress in human civilization had apparently made self evident. ${ }^{22}$ Slavery was seen as an archaic form of labor organization that had been bounded and made non appropriate for civilized Europeans through the efforts of humanitarianism and the will of God. ${ }^{23}$ An early statement from the Anti-Slavery Reporter is illustrative:

The Formation of the British and Foreign Anti-Slavery Society constitutes an era in the history of human benevolence. . . . it identifies the two things, Slavery and the Slave-trade . . . equally to be abhorred and jointly to be exterminated. ${ }^{24}$

${ }^{21}$ Aborigines Protection Society, "Slavery and The Slave Trade Throughout the World," Extracts from the Papers of the Proceedings of the Aborigines Protection Society, May 1839, Library of Congress.

${ }^{22}$ On the creation of free labor ideology, see, David Brion Davis, Slavery and Human Progress (Ithaca: Cornell University Press, 1984), 352-365.

${ }^{23}$ I am alluding to scholarship which portrayed the ending of the trans-Atlantic slave trade as a purely humanitarian effort. For example, Reginald Coupland, The British Anti-Slavery Movement (London: Frank Cass,1964) and Roger Anstey, The Atlantic Slave Trade and British Abolition, 1760-1810 (Atlantic Highlands, Humanities Press, 1975)

${ }^{24}$ Anti-Slavery Reporter, January 15, 1840. 
Slavery was a horror, but it, also, was seen as a less efficient form of labor. In a paper delivered to the Anti-Slavery conference of 1840, Joseph Sturge echoed the sentiments of many in the organization when he stated that, "the superiority of free over slave labor, is in fact now so generally known. .." there was no need to prove it. ${ }^{25}$ Borrowing from Adam Smith, ${ }^{26}$ Sturge added that slave labor was less productive than free labor because the slave never worked as hard as free man and the costs of the slaves upkeep was borne by the master.

Although this confidence in free labor would be later tested during the free sugar controversy, Sturge's argument also failed to take into account one significant factor. The slave was possessed completely as a commodity, while only the labor power of the "free" laborer was possessed as a commodity. ${ }^{27}$ Specifically, in the case of the British Caribbean, this meant that planters could buy slaves and use them until they expired then, simply, replenish the stock. This would tend to drive down the costs of "wear and tear."

As the avatar of native protection, the BFASS would carry this aversion to slave labor with it in its efforts against African slavery. This would serve European powers in establishing the moral and ideological hegemony over Africa as a prelude to imperialism. ${ }^{28}$ Although capitalism had profited from unfree labor on slave plantations in the Americas, as new forms of labor organization developed, slave labor came to be defined as the opposite of free labor.

${ }^{25}$ Ibid., July 29, 1840. In the controversy over free sugar, Sturge would be disproved.

${ }^{26}$ Sturge quoted from Adam Smith's treatise, An Inquiry into the Nature and Causes of the Wealth of Nations: A Concordance, emphasizing Smith's so called "wear and tear" argument that the wear and tear of the slave was appropriated by the master.

${ }^{27}$ Robert Miles, Capitalism and Unfree Labor: Anomaly or Necessity (London and New York: Tavistock Publications, 1987), 27.

${ }^{28}$ Davis, Slavery and Human Progress, 365. 
Humanitarian opposition to slavery was part of this universalization of free labor. ${ }^{29}$

However, as Frederick Cooper has noted, the opposition of free versus slave labor was not always so fixed and, in fact, was a social construction that was historically defined. ${ }^{30}$

Historically, in the West, boundaries between free and unfree labor were not always so seemingly fixed and opposed. For example, Robert Steinfeld has noted that, in $17^{\text {th }}$ century England, the prevalent form of consensual manual labor was unfree labor. ${ }^{31}$ As mentioned previously, even with the closing of the Atlantic slave trade in 1807, British planters still were able to use non free labor in the form of indentured labor. What this indicates is that, as in the debate over free sugar, the efficacy of free labor was not self evident and had to be contested. The right of definition had to be won through ritualized protests against slavery in all its forms.

As mentioned previously, the BFASS stance on free labor would prove troublesome for the organization. During the 1840 's and 1850 's the Society was split over the issue of "free sugar." In 1841 the British government announced its decision to lower tariffs on sugar imports from foreign countries. This meant that slave grown sugar from Cuba and Brazil would flood the British market. ${ }^{32}$ However, it also meant that sugar prices for working class Englishmen would

${ }^{29}$ Gyan Prakash, "Colonialism, Capitalism and the Discourse of Freedom," in Shahid Amin and Marcel Van de Linde, eds., Peripheral Labor Studies in the History of Partial Proletarianization (Cambridge: Press Syndicate of the University of Cambridge, 1997), 10.

${ }^{30}$ Frederick Cooper, "Conditions Analogous to Slavery," in Frederick Cooper, Thomas Holt and Rebecca Scott, eds., Beyond Slavery: Explorations of Race, Labor, and Citizenship in Postemancipation Societies (Chapel Hill: The University of North Carolina Press, 2000), 9.

${ }^{31}$ Robert J. Steinfeld, The Invention of Free Labor: The Employment Relation in English and American Law and Culture, 1350-1870 (Chapel Hill, University of North Carolina Press, 1991), 4. See also, Thomas Holt, The Problem of Freedom: Race, Labor and Politics in Jamaica and Britain, 1832-1938 (Baltimore: Johns Hopkins University Press, 1992).

${ }^{32}$ For example, in 1815 Cuba produced 42,000 tonnes of sugar. This represented one half of the total output of sugar from the British colony of Jamaica. By 1840, however, Cuba was now producing $60 \%$ more sugar than all of the British West Indies colonies combined. 
decline. ${ }^{33}$ Cuban and Brazilian sugar was cheaper and of higher quality than sugar grown in British colonies, even though, it was slave-grown produce.

The Central Committee of the BFASS campaigned vociferously against the lower tariffs. In a memorial to he British government in 1841, it argued that if the duties on foreign sugar were decreased, the British government would be giving an impetus to ". . the nefarious traffic in human beings ...."34 Both Cuba and Brazil still imported slaves. Consequently, the BFASS felt that an open market for slave grown sugars from Brazil or Cuba in Britain would give impetus to the slave trade from Africa since the increased demand for cheaper sugar would necessitate increased production and, hence, increased importation of slaves. ${ }^{35}$ By consuming slave grown sugar, the BFASS also felt that the British would be accomplices to aiding slavery and the slave trade and would also, ironically, besmirch their own accomplishments against the slave trade. As the London Committee of the BFASS stated:

The question then arises, shall this great country which has relieved itself from the guilt of continuing the slave trade, which has emancipated millions of slaves in its distant dependencies, so legislate now, as to stultify its own glorious acts. . . ${ }^{36}$

In addition, as mentioned previously, the BFASS felt that the uncompetitive nature of British sugar production in the Caribbean was caused by inefficiency on the part of the planters and not

Temperley, British AntiSlavery, 138.

${ }^{33}$ Concerning the importance of sugar as a national taste in Britain see James Walvin, Making the Black Atlantic: Britain and the African Diaspora (London and New York: Cassell, 2000), Ralph Austen, "Private Tooth Decay as Public Economic Virtue: The Slave-Sugar Triangle, Consumerism and European Industrialization," Social Science History, 14 1 (1990): 95-115.

${ }^{34}$ Temperley, British AntiSlavery, 141; The Anti-Slavery Reporter, April 7, 1841.

${ }^{35}$ Anti-Slavery Reporter, July 1, 1846, 101.

${ }^{36}$ Ibid., 102. 
free labor itself. ${ }^{37}$ So, if free sugar production in the Caribbean was made more competitive, there would be no need for slave grown sugar.

Although the Central Committee saw its battle against slave grown sugar as an altruistic struggle for "the great principles of universal justice and benevolence," it could not persuade a number of its auxiliary societies with this high minded language. ${ }^{38}$ For many of the auxiliary committees of the BFASS, the important point was not the moral issue of the proliferation of slavery and the slave trade, but the economic issue of cheap sugar for working class Englishmen. They accused the London committee of caring more about slaves than British workers, who would benefit from the cheaper prices and resultant tooth decay. C. P. Villiers, ${ }^{39}$ one of the leading proponents of free sugar in the House of Commons, summed up the critique of the BFASS when he stated that they “. . . had at last persuaded themselves that a black man was better than a white one."40 The critics of the BFASS also pointed out that the organization arbitrarily protested against slave- grown sugar while other slave-grown products like cotton were ignored. ${ }^{41}$ Slave grown cotton was significant in providing part of the so called "primitive

\footnotetext{
${ }^{37}$ Ibid., July 29, 1840.
}

${ }^{38}$ Ibid., April 7, 1841. Many of the auxiliaries which rebelled against the leadership of the Central Committee on the sugar issue were located in previous anti slavery strongholds like Manchester, Liverpool and Birmingham. Ibid., 151.

${ }^{39}$ Villiers was also a member of the BFASS and had attended the 1840 Anti-Slavery convention.

${ }^{40}$ Temperley, British AntiSlavery, 149.

${ }^{41}$ For example, in 1847 the British government refused to import slave grown sugar from Zanzibar, but it accepted slave grown cloves. Abdul Sheriff, Slave, Spices and Ivory in Zanzibar (Athens: Ohio University Press, 1987), 69. BFASS protests against slave grown cotton were more muted. BFASS memorials against slave grown sugar, although deploring the use of slave grown products, merely called for a nebulous appeal to switch to free grown cotton, like cotton produced in India. Anti-Slavery Reporter, January 1, June 1, 1846.

$$
\text { Page -36- }
$$


accumulation," necessary for the take off of industrialization in England. ${ }^{42}$ The illusory condemnation of slave grown sugar masked the real connection between capitalism and unfree labor.

Although the duties on foreign sugars were eventually repealed in 1851, the free sugar debate caused a split in the organization. At the annual meeting of the BFAS in 1844, the society reversed its stance and voted for free trade "produce of piracy and felony." ${ }^{, 43}$ This was later reversed at a subsequent meeting, but the effect was felt. In 1851 there were twenty-six free trade auxiliaries of the BFASS in Britain.

Between 1834 and 1838 British West Indies' sugar production fell by $10 \%$ while the price of sugar in Britain rose $40 \% .^{44}$ British sugar production eventually recuperated after the liberalization of sugar prices, but, as Seymour Drescher has commented, this revitalization of the British sugar industry also coincided with the expansion of so called "coolie" indentured labor from parts of Asia. ${ }^{45}$ Ultimately, the resurgence of British sugar was due more to reliance upon unfree labor. The "burden" that organizations like the BFASS felt in regards to aboriginal welfare was in actuality the burden of how best to assimilate their labor into a capitalist system as "free" laborers. This confidence in the superiority of "free" labor, despite its weaknesses in the British West Indies, ${ }^{46}$ would, also, become one of the prominent traits of the ASAPS in its

${ }^{42}$ Miles, Capitalism and Unfree Labor, 46.

${ }^{43}$ The Anti-Slavery Reporter, August 1, 1846, 122.

${ }^{44}$ Seymour Drescher, From Slavery to Freedom: Comparative Studies in the Rise and Fall of Atlantic Slavery (Washington Square: New York University Press, 1999), 420.

${ }^{45}$ Ibid., 424.

${ }^{46}$ The BFASS Central Committee could take comfort that free labor was more efficient than slave labor except, as in the British West Indies, where there was mismanagement, as it stated in a memorial to one of the recalcitrant auxiliary societies. Temperley, British 
campaigns against slavery and other forms of bonded labor in the twentieth century.

The founding of the BFASS had been a propitious moment for the anti slavery movement, for it came at a time when the anti slavery sentiment in Great Britain was on a downswing. ${ }^{47}$ The single object of the BFASS had been ". . . the universal abolition of slavery and the slave trade, by moral, religious and other pacific means. .."48 In this regard, it differed slightly with another humanitarian organization, the Aborigines Protection Society, founded about the same time. The APS would focus more upon aboriginal welfare as opposed to slavery, but the diffident results of their efforts would be similar. Both organizations would carry the banners of free labor and trusteeship in their pursuit of aboriginal protection.

\section{The Aborigines Protection Society}

The Aborigines Protection Society formed out of a Select Committee of the House of Commons organized by Dr. Thomas Hodgkin (1798-1866) and Thomas Fowell Buxton (1786-1845) on 14

July 1835. The stated aim of this committee was,

... to consider what measures ought to be adopted with regard to the native inhabitants of countries where British settlements are made, and to the neighboring tribes, in order to secure to them the due observance of justice and the protection of their rights, to promote the spread of civilization among them, and to lead them to the peaceful and voluntary reception of the Christian religion. ${ }^{49}$

AntiSlavery, 148. However, as Seymour Drescher has proven the slave production of sugar in the West Indies was highly effecient. See Seymour Drescher, Econocide: British Slavery in the Era of Abolition (Pittsburgh: University of Pittsburgh Press, 1977).

${ }^{47}$ Anti-Slavery Reporter, January 151840.

${ }^{48}$ Ibid., May 19, 1841.

${ }^{49}$ H. R. Fox Bourne, The Aborigines Protection Society: Chapters in Its History (London: P. S. King and Son, 1899), 3. 
The Select Committee also sought to address the injuries suffered by aboriginal peoples as a result of European economic contact. ${ }^{50}$

Buxton's involvement with the new Society also meshed with his so called "New Africa" policy which involved using commerce and Christianity to end the slavery in Africa. ${ }^{51}$

Practically, Buxton proposed using a treaty system with African leaders and establishing British settlements in Africa for the purposes of commerce and cultivation of the land. The fruition of his grand vision was a failed expedition up the Niger river in 1841 , ostensibly to promote “civilization" and gather scientific information.

A deep veneration of William Penn, the Quaker also influenced Hodgkin's concern for aboriginal peoples. ${ }^{52}$ However, the immediate event which led to the formulation of the Committee, according to John Harris, ${ }^{53}$ was the so-called sixth "Kaffir War" in 1834-5 on the eastern frontier of Britain's Cape Colony in Southern Africa. ${ }^{54}$ The "Sixth War" represented the climax of an epic land struggle between the Boers and the Xhosa over Xhosa grazing land Zuurveld on the frontier of the Eastern Cape Colony. ${ }^{55}$ The events of this war included the

\section{${ }^{50}$ Aborigines Protection Society, Report of the Parliamentary Select Committee on} Aboriginal Tribes, (London: William Ball and Company, 1837), vii.

${ }^{51}$ John Gallagher, "Fowell Buxton and the New African Policy," Cambridge Historical Journal 10 (1950), 45.

${ }^{52}$ Nworah, "Humanitarian Pressure Groups", 114.

${ }^{53}$ Harris became the organizing secretary of the ASAPS in 1909 but had been deeply involved in humanitarian issues like the Congo Reform Association.

${ }^{54}$ John Harris, A Century of Emancipation (Port Washington and London: Kennikat Press, 1971), 75.; George W. Stocking, "What's in a Name? The Origins of the Royal Anthropological Institute," Man 6 (Sept 1971): 369.

${ }^{55}$ J.D. Omer-Cooper, History of Southern Africa (London: St. James Curry Publishers, 1994), 69-70. 
killing of approximately four thousand Xhosa and the annexation of their land. This, according

to H. R. Fox Bourne the last president of the APS before its merger, convinced Buxton ${ }^{56}$ to adjourn a Select Committee in the House of Commons to address the rights of aborigines within British and foreign territories in $1835 .{ }^{57}$

The Committee met in three sessions between 1835 and 1837 and heard evidence from South Africa, Canada, British Guiana, Australia, New Zealand and the Pacific Island possessions of Great Britain. ${ }^{58}$ The committee interviewed forty-five witnesses encompassing more than one thousand pages of testimony. The majority of the witnesses were either missionaries or military personnel. However, the committee, also, interviewed two Africans from South Africa and a Native American. Much of the evidence alluded to " ... the injustice and cruelty with which the Aborigines have hitherto been treated . . f from their intercourse with European nations ..."59 For instance, in Newfoundland a Captain Buchan testified that the numbers of the Micmac Indians in the Great Lake region had declined to the point of extinction due to the encroachment of European civilization. ${ }^{60}$ A Native American chief of the Chippeway lamented that:

${ }^{56} \mathrm{H}$. R. Fox Bourne states that Buxton convened the committee due to the prodding of Dr. Thomas Hodgkin. And it is Hodgkin whom he euphemistically titles the "the father and founder of the Aborigines Protection Society." Fox Bourne, The Aborigines Protection Society, 3.

${ }^{57}$ Buxton was also an MP in the House of Commons. His party affiliation was nominally Whig. Harris, A Century of Emancipation, 20.

${ }^{58}$ Members of the Committee included T. F. Buxton, William Gladstone, Sir Rufane Donkin (former governor of Cape Colony), Mr. Charles Lushington (younger brother of Steven Lushington had served in Bengal for the East India Company), Sir George Grey, Joseph Pease (Quaker member of parliament), Edward Baines, Andrew Johnston, and Charles Hindley. William Gladstone was added as a replacement. He would later become Prime Minister of Great Britain and helped to write the first draft of the report. APS, Report of the Select Committee on Aboriginal Tribes, xii.

\footnotetext{
${ }^{59}$ APS, Report of The Parliamentary Select Committee on Aboriginal Tribes, v. ${ }^{60}$ Ibid., 5.
} 
We were once very numerous, and owned Upper Canada, and lived by hunting and fishing; but the white men, who come to trade with us, taught our fathers to drink fire waters, which has made our people poor and sick, and killed many tribes, till we have become very small. ${ }^{61}$

In South Africa the evidence described the ill treatment of Africans by Boers. ${ }^{62}$ The report even included a recommendation by the governor of the Cape Colony, Sir Benjamin D'Urban, that "a complete and effectual reformation of our system of proceeding with the native tribes ... has become absolutely necessary."

The Committee presented its report to Parliament in June 1837 and submitted nine recommendations for the humane governance of non-European peoples. ${ }^{64}$ These recommendations would become the basis for a charter of aboriginal rights for the Aborigines Protection Society in $1840 .{ }^{65}$ The APS was formed in 1838. Standish Motte, drafted the society's charter on 26 July 1840 . The charter was intended to provide the legislative framework for the protection of aboriginal rights against both political and economic encroachment by British

${ }^{61}$ Ibid.

${ }^{62}$ The formulation of the Select committee also coincided with the expansion by the Boers into Xhosa land on the frontier of Cape Colony.

${ }^{63}$ Fox-Bourne, The Aborigines Protection Society, 5

${ }^{64}$ H. C. Swaisland, "The Aborigines Protection Society in British Southern and Western Africa," (Ph.D. diss., Oxford University, 1968), 11. Some of these recommendations were to place protection of natives under the executive not colonial legislatures; contracts for service were to be limited while no vagrancy laws or other regulations were to limit the ability of aborigines from selling their labor at the best price; no sale of alcohol; no sale of crown lands("native lands") to British subjects; no acquisition of new territories without the sanction of the home government; religious instruction of indigenous people. The recommendations declared it "inexpedient" to enter into frequent treaties between local governments and ethnic groups. Lastly, the report stated that missionaries, "those gratuitous and invaluable agents" should be protected and assisted. Nworah, "British Humanitarian Groups," 115-117. Groups," 117.

${ }^{65}$ The report was published by the APS. Nworah, "British Humanitarian Pressure Page -41- 
colonial subjects. ${ }^{66}$ Motte's charter contained certain general principles of legislation which mirrored the themes of the earlier Select Committee on Aboriginal rights but also went beyond the scope of the Committee to some degree.

The new APS charter called for the appointment of committees to investigate problems, make political and commercial treaties and to, also, undertake anthropological studies of aboriginal peoples. ${ }^{67}$ In addition, the charter called for the protection of rights of property, and administration of justice for the "native." "Instruction and amelioration" of aboriginal peoples through moral and physical means was also one of the tenants of the charter. ${ }^{68}$ Moral instruction meant religious emersion in the fundamentals of Christianity while physical "betterment" entailed the building of schools for agricultural and mechanical instruction.

The economic and anthropological leanings of the new society could be easily discerned from the charter but the driving force for the society would always be to:

Render it the paramount duty of the people and government truly, justly and humanely to fulfill the great trust in them reposed ... that in grasping the commerce of the earth ... we do not demoralize ruin and exterminate those who by birthright are nature's lords of the soil . . .." 69

The upstart APS sought to promote aboriginal rights through extensive correspondence, the publication of documents and papers, interviews and the presentation of petitions to the crown and the legislature. The APS also held "public conversation meetings" to explain the principles of the organization to the public and to summon evidence from people who had first hand

\footnotetext{
${ }^{66}$ Standish Motte, Outline of a System of Legislation for Securing Protection to the inhabitants of all countries colonized by Great Britain, (London: J. Murray, 1840), 3.

${ }^{67}$ Ibid., 12.

${ }^{68}$ Ibid., 27

${ }^{69}$ Ibid., 6
} 
experience with indigenous peoples in various parts of Britain's colonies. ${ }^{70}$ These "native" "experts" included travelers, missionaries, retired officials and other people who had first hand experience in foreign and exotic places like Africa, New Zealand, the Americas and the Pacific islands. In 1844 the APS began to publish their own journal, The Aborigines Friend or Colonial Intelligencer, to educate people about the activities of the organization ${ }^{71}$

Most of the original members of the organization came from the middle class and were Quakers. ${ }^{72}$ Although the Society was not officially associated with any political party, many of its members were Liberal. ${ }^{73}$ The APS and the BFASS had members and correspondents all over the world. For example, in the United States of America Charles Sumner and Arthur Tappan were honorary members of the APS. ${ }^{74}$ In Germany and France, respectively, Baron von Humboldt and Alexis De Tocqueville were also honorary members of the APS. ${ }^{75}$ Until their amalgamation in 1909, both the Aborigines Protection Society and the British and Foreign AntiSlavery Society frequently overlapped in terms of membership and the issues they addressed.

The respective financial weaknesses of both organizations, reinforced by overlapping memberships and a plethora of deaths, led to unification on 24 June 1909. For example, 1906

\footnotetext{
${ }^{70}$ Aborigines Protection Society, $3^{\text {rd }}$ Annual Report, (London: William Ball and Company, 1840), 141.

${ }^{71}$ After the amalgamation of the BFASS and ASP the journal became the Anti Slavery Reporter and Aborigines Friend.

${ }^{72}$ Swaisland,'The Aborigines Protection Society," 18.

${ }^{73}$ Ibid., 21.

${ }^{74}$ Aborigines Protection Society, $2^{\text {nd }}$ Annual Report, (London: P. White and Son, 1839). Charles Pickney Sumner was the father of the famous anti-slavery senator, Charles Sumner. Tappan was another famous abolitionist. He worked with William Lloyd Garrison on the Liberator and also helped to found the New York City Anti-Slavery Society.

${ }^{75}$ Ibid.
} 
Annual Report of the BFASS stated that revenues from donations and legacies, which made up a large part of the Societies income, had declined to the point that they were not enough to meet the normal operating expenditure of the organization. ${ }^{76}$ Most of the then members of both the APS and BFASS were born around $1840 .{ }^{77}$ By the early $20^{\text {th }}$ century, due to the vagaries of human life, they were beginning to die off.

With the amalgamation, Sir Thomas Fowel Buxton ${ }^{78}$ (1837-1915) became the first president of the newly formed ASAPS. His nephew Travers Buxton became the Society's first Corresponding Secretary with Sir John Hobbis Harris ${ }^{79}$ (1874-1940) serving as the Organizing Secretary.

Both organizations followed in the tradition of the anti slavery movement in Great Britain and used petitions to influence the home government. Consequently, as Kingsley Nworah has stated, these organizations became "watch dogs for aboriginal rights" within British colonies and

\footnotetext{
${ }^{76}$ Nworah, "British Humanitarian Pressure Groups," 198.

${ }^{77}$ Ibid.
}

${ }^{78}$ This Sir Thomas Fowell Buxton was the grandson of the more famous abolitionist Sir Thomas Fowell Buxton. The younger Buxton's father was Sir Edward North Buxton. The younger Buxton had also been president of the British and Foreign Anti Slavery Society in 1899 and governor of South Australia from 1895-1898. Nworah, "British Humanitarian Pressure" Groups, note 1, 200.

${ }^{79}$ Sir John Harris had previously served as a missionary in the Congo and had traveled to West Africa, Rhodesia and South Africa. In the Congo he worked for the Regions Beyond Missionary Union and the Congo Balolo Mission. Harris also worked as secretary for the Congo Reform Association. Harris brought a wealth of administrative experience to the ASAPS as Organizing Secretary. For instance, in 1910 Harris reorganized the ASAPS creating a parliamentary sub committee which would focus more of the Society's energies on parliament through the creation of a committee of MP's. With this reorganization Harris became Parliamentary Secretary while Travers Buxton became corresponding Secretary. Until his death in 1940, Harris would be the single most important individual in the ASAPS. Rachel Whitehead, "The Aborigines Protection Society and the Safeguarding of African Interests in Rhodesia," (Ph.D. diss., Oxford University, 1975),note 1, 88.; Nworah, "Humanitarian Pressure Groups," 214. 
foreign territories.$^{80}$ However, this humanitarian concern for aboriginal peoples was more of a call to reform or, more appropriately, a call to conform to the ideals of trusteeship. It was meant "to assist in protecting the defenseless; and promoting the advancement of uncivilized tribes . . " $\$ 11$ The humanitarian critique of the BFASS and ASP did not question colonialism essentially.

Instead, it offered a criticism from within. For, as stated in the second annual report of the APS: . . . the committee instead of opposing colonization only desired to see the system on which it is now extensively carried on, so improved as to render the spread of British colonies beneficial, and not ruinous, to the aborigines. ${ }^{82}$

Trusteeship was the clarion call of aboriginal rights. The Select Committee report of 1837 implicitly stated that Britain had a moral responsibility for the welfare of its aboriginal wards. The doctrine of trusteeship, which was first articulated by Edmund Burke in 1783, stated that political and economic relationships with non Western peoples involved a certain moral responsibility on the part of the colonizing power. ${ }^{83}$ This "burden" of "moral responsibility" would later be carried by the APS in it's defense of Native Americans in North America, Khoisan in South Africa, Maori in New Zealand and other aboriginal peoples. Following the creation of the ASAPS in 1909, the ideal of trusteeship would also be paramount in the Society's criticisms of forced labor in the East Africa Protectorate. The issue of forced labor in colonial Kenya would re-emphasize the Society's historic support of trusteeship and its proselytizing efforts in favor of trusteeship and free labor.

In their quest for aboriginal rights both the APS and the BFASS embodied certain traits

\footnotetext{
${ }^{80}$ Nworah, "Humanitarian Pressure Groups,” 127.

${ }^{81}$ This was one of the mottos of the APS.

${ }^{82}$ Aborigines Protection Society, $2^{\text {nd }}$ Annual Report, 21

${ }^{83}$ Whitehead, "Safeguarding of African Interests," 4.
} 
which delineated their brand of humanitarianism. ${ }^{84}$ Both organizations emphasized free labor as a means of developing aboriginal peoples. Their denouncement of "slavery in all its forms" was more of an argument for the benefits of free labor and capitalism in general. ${ }^{85}$ As mentioned previously, it represented part of the process of the "naturalization" of free labor contingent with the abolition of slavery in $1833 .{ }^{86}$ One of the impacts of the abolition movement which spawned both the APS and the BFASS was the development of slavery and freedom as two mutually exclusive forms of labor. ${ }^{87}$ However, as Drescher has stated, "For most of human history the expression 'free labor' was an oxymoron." ${ }^{\prime 8}$ But, the free labor that the BFASS and APS spoke of seemingly meant the ability to buy and sell one's labor power on the market as a commodity.

In fact, one of the founding members of the BFASS, John Sturge, wrote a pamphlet as early as 1827 which advanced the benefits of free labor over slave labor. ${ }^{89}$ Sturge even postulated that eventually free labor in the United States would lead to the end of plantation slavery. The APS commitment to free labor was also evident. In 1840 the APS passed a resolution which stated:

That wherein the principle of free trade is acted on and the products of free and slave labour thereby brought into full and fair competition, the former must inevitably triumph over the latter, and the destruction of slavery and the slave

${ }^{84}$ The BFASS, APS and, later, the ASAPS differed slightly with more religious humanitarian organizations, as mentioned in the introduction.

${ }^{85}$ Cooper, Plantation Slavery, 26.

${ }^{86}$ Prakash, "Discourse of Freedom," 10.

${ }^{87}$ Drescher, From Slavery to Freedom, 428. See also Robert J. Steinfeld, The Invention of Free Labor: The Employment Relation in English American Law and culture, 1350-1870 (Chapel Hill: University of North Carolina Press, 1991); David Brion Davis, The Problem of Slavery in the Age of Revolution, 1770-1823 (Ithaca: Cornell University Press, 1975).

${ }^{88}$ Drescher, From Slavery to Freedom, 401.

${ }^{896}$ "Free Trade and Free Labour, the Surest Means of Abolishing the Slave Trade and Slavery,” Aborigines Protection Society $3^{\text {rd }}$ Annual Report, 141.

Page -46- 
trade following as a necessary consequence..$^{90}$

APS support for free labor also mirrored support for aborigines owning their own lands and maintaining a right to their own produce. For example, Henry Richard Fox-Bourne ${ }^{91}$ stated in an August 1900 paper delivered to the International Congress on Colonial Sociology in Paris:

a right to the land of which they are the prior occupants and to its use in ways approved by them, or at any rate to so much thereof as may be requisite for their sustenance and prosperity under conditions not less favorable to them than those which they enjoyed when they were still its sole owners. ${ }^{92}$

Peasant agriculture was also supported as a means of ending the East African slave trade. For example, at public meeting held on 31 May 1895 on the topic of the African slave trade and British responsibility, the APS member J. M. Tucson articulated the society's position beautifully:

in order to improve Africa and to destroy completely the foreign slave trade it is indispensably necessary to teach the population to cultivate her soil in order to obtain those valuable articles of tropical production which are and ever must continue to be required by the natives of temperate zones where similar production cannot be raised.. . . By these means legitimate commerce will be extended and rendered permanently advantageous and renumerative. ${ }^{93}$

However, the right of aborigines to work their own land was contingent upon good guidance from Europeans. This strategy of instruction and agriculture, or the "bible and plough," had been one of the fundamental virtues extolled by Sir Thomas Fowell Buxton in his famous work The

${ }^{90} \mathrm{Ibid}$.

${ }^{91}$ H. R. Fox Bourne was Secretary of the APS from 1889-1909.

${ }^{92}$ Quoted in Nworah, "Humanitarian Pressure Groups," 185.

93“"General Remarks on Africa,” 31 May 1895, BFASS/APS, Box G1/A, "Africa, General," Rhodes House Library, Oxford. 
African Slave Trade and its Remedy ${ }^{94}$ APS support for peasant commodity production also

revealed a fear that aborigines would not make better use of their land. ${ }^{95}$ Symbolically, this belief in the virtues of peasant commodity producers would also surface much later in a scathing critique of Kenya Colony's economic policy by the merchant capitalist Sir Humphrey Legget. Legget criticized the administration in Kenya for penalizing African commodity production in favor of European production. ${ }^{96}$

A second characteristic, associated mainly with the APS, was a fascination with ethnographic studies of so called "vanishing cultures." The APS was founded with a philanthropic mission to protect non Europeans in colonial territories from extinction. It also was built upon a base of scientific study of different cultures which reinforced the philanthropic aims of the society. ${ }^{97}$

Some of it early members, like Thomas Roscoe, Simon Wilkin and, later, Robert Young, were trained philologists. ${ }^{98}$ Dr. Thomas Hodgkin, the founder of the APS, was a demonstrator of morbid anatomy at Guy's Hospital in London. ${ }^{99}$ Hodgkin, through the APS, had also been

${ }^{94}$ Thomas Fowell Buxton, The African Slave Trade and its Remedy (London: John Murray, 1840), 482-83.

${ }^{95}$ H. R. Fox Bourne, The Claims of Uncivilized Races: A Paper Submitted to the International Congress on Colonial Sociology, Held in Paris in August, 1900, (London: Aborigines Protection Society, 1900), 9.

${ }^{96}$ Maxon, Struggle For Kenya, 235-36.

${ }^{97}$ Interestingly enough, one of the mottos of the APS was "Ab Uno Sanguine" or of one blood.

${ }^{98}$ Ronald Rainger, "Philanthropy and Science in the 1830's: British and Foreign Aborigines Protection Society," Man 15 (4) (Dec 1980): 714, note 5. Also, William Allen, one of the founding members of the BFASS, had been a Fellow of the Royal Society and a lecturer in Chemistry at Guy's Hospital. Temperley, British AntiSlavery, 69.

${ }^{99}$ Rainger, "Philanthropy and Science," 703. 
instrumental in forming the Société Ethnologique de Paris in $1839 .{ }^{100}$ His interest in protecting aborigines reinforced a scientific interest in preserving cultural relics. For instance, in 1835 he delivered a paper to the Philological Society which discussed the importance of preserving nonEuropean languages. ${ }^{101}$ In his paper, Hodgkin felt that many non European languages were losing speakers due to the encroachment of European civilization and language.

Hodgkin's interest in linguistics and ethnology was influenced by the work of James Cowles Pritchard, one of the leading ethnologists of the day. ${ }^{102}$ Pritchard used a historical approach to ethnography and linguistics to examine the genesis of different "races."103 This historical approach buttressed his belief in the inevitability of the extinction of certain ethnic groups. He, actually, delivered a paper to the APS entitled "On the Extinction of Some Varieties of the Human Race."104

APS' interest in the preservation of alien cultures resulted in the appointment of a "Committee of the British Association for the Advancement of Science" in 1839. ${ }^{105}$ One of the aims of the committee was to give questionnaires to travelers concerning the ethnographic characteristics of aboriginal cultures they would encounter. The questionnaires asked the respondents to fill out information concerning physical characteristics, such as the thickness of the skulls, language, family life, domestic animals, government and laws, geographic statistics,

${ }^{100}$ Ibid, 711-12.

${ }^{101}$ Ibid.

${ }^{102}$ Ibid., 703.

${ }^{103}$ Ibid. Pritchard believed in monogenesis.

${ }^{104}$ Aborigines Protection Society, "Queries Respecting the Human Race," $3^{\text {rd }}$ Annual Report, (London: White and Son, 1840).

${ }^{105}$ Ibid. 
social relations, religions and superstitions. ${ }^{106}$

This ethnological interest in non-European cultures fortified the philanthropic mission of the APS. On the one hand, the APS wanted to protect aboriginal peoples from extinction. As a manifestation of the need to protect, the APS embodied a desire to preserve the scientific knowledge of these cultures. The preservation of scientific knowledge of alien cultures also fell in line with the APS belief in the right of Africans

to the maintenance of the social, religious, political, and other institutions they have established among themselves, subject only to such changes as they may voluntarily agree to under the guidance of the more civilized visitors and residents whom they have intelligently admitted to partnership or supremacy in the occupation or use of their country. ${ }^{107}$

However, this respect for aboriginal cultural institutions was at odds with the dominant world view of many missionary groups. For many religious groups, active in the colonizing experience, certain facets of indigenous cultures, like female circumcision in Africa, or polygamy were atavistic and against the teachings of Christianity. In contrast the APS felt that “... even savages have a right to their own institutions, however, degraded, if they are not injurious to outsiders ... , 108

APS respect for aboriginal cultural institutions also belied a certain contempt for aboriginals who had become assimilated into Western culture. A remark from the Aborigines Friend describing Westernized Africans in 1896 is illuminating:

there is too much imitation of English manners and customs amongst them, too much desire, by showy dressing and stylish deportment, to adopt what may be

\footnotetext{
${ }^{106}$ Ibid.

${ }^{107}$ Fox Bourne, "The Claims of Uncivilised Races," 6.

${ }^{108}$ Ibid., 11.
} 
only the veneer of civilization, not the thing itself. ${ }^{109}$

This attitude toward Westernized Africans was congruent with the APS stance on colonialism itself, and also reflected the Social Darwinist thinking of the time period. Colonialism was meant to, only, improve aboriginal people. This implied improvement in perpetuity. Aborigines were not supposed to become truly civilized or westernized, just merely ameliorated to reinforce and justify the superiority of European civilization and the "civilizing mission." On this topic, the remarks of H. R. Fox Bourne are illustrative:

The transition from barbarism to civilization must perforce be slow, and attended by frequent failures, which should serve as lessons for future guidance; and, when the utmost has been done, it must not be expected that the highest civilization of the blacks will be in all respects equal to, still less identical with, the highest civilization of the whites ... ${ }^{110}$

Westernized aborigines contradicted this vision just like the negative effects of capitalist labor practices on tribal societies contradicted the ideal of trusteeship.

The desire to preserve and protect also belied a certain conception of aboriginal peoples. The stated mission of the APS was "to assist in protecting the defenseless, and promoting the advancement of uncivilized tribes." 111 The APS viewed aborigines as victims who were unable to help themselves. ${ }^{112}$ "Where white men, or men of other color but endowed with as much physical vigor, can live and thrive, . . . a stern law of nature appears to render inevitable the

${ }^{109}$ Quoted in Nworah, "Humanitarian Pressure Groups," 188.

${ }^{110}$ Fox-Bourne, “The Claims of Uncivilised Races," 12

${ }^{111}$ Quoted from the "Report of the Parliamentary Select committee on Aboriginal tribes."

${ }^{112}$ Whitehead, "The Aborigines Protection Society and the Safeguarding of African Interests," 13. 
ultimate disappearance of the earlier and weaker occupants of the country." "113 This construction of the aborigine in British and foreign dependencies was a reflection of the paternalism inherent in the civilizing mission of the APS. Few of the members of the APS, or the later ASAPS, had actually had any contact with the aborigines they were supposed to be protecting. This not only reflected the physical gulf which impeded contact, but also reflected the conceptual gulf which reinforced the paternalistic concern for the aborigine from afar.

As humanitarian pressure groups, both the APS and BFASs were involved in numerous controversies $^{114}$ in their role as protectors of "native rights" throughout the British empire. The role of protectors of aboriginal rights reflected their position in regards to trusteeship. Again, the succinct comments of H. R. Fox-Bourne are revealing:

White men are, or should be, in the position of guardians, or of elder or more fortunate brothers, to the blacks with whom, by their own choice and primarily for their own benefit, they are in contact. Whenever and wherever such contact is brought about, uncivilised races, by reason of their lack of civilisation, are in need of, and ought to have, the zealous protection and discreet control of those more civilized than they are. ${ }^{115}$

Historically, the APS concentrated mainly on the problems of imperialism while the BFASS focused more specifically on slavery and the slave trade. However, Free labor, and trusteeship were the fundamental issues which defined aboriginal protection for both the BFASS and the

\footnotetext{
${ }^{113}$ Fox-Bourne, "The Claims of Uncivilised Races," 7.
}

${ }^{114}$ The numerous controversies or test cases for colonial trusteeship involved the antiliquor campaign in West Africa in 1887; the Chinese "slavery" issue in South Africa, 1902-1910; slavery in Portuguese West Africa, 1902-1910 and the Congo campaign against the abuses of King Leopold's rule, 1884-1903. Although Nworah counts the Gold Coast Emancipation Ordinance of 1874 as one of the 'victories' of the APS, in particular, the victories of the APS and the humanitarian lobby upon colonial policy can not be measured in terms of direct impact but instead should be measured in terms of creating a moral atmosphere.

${ }^{115}$ Fox-Bourne, “The Claims of Uncivilised Races," 12. 
APS and marked the boundaries where their interests met. The confluence of their interests would also surface in the later forced labor controversy and was important in this regard. The society's methods of influencing the British crown through petitions and conferences would be adopted in the later controversies of forced labor. The later lack of virulent criticism of communal labor, as a cultural relic of merry old Africa, by the ASAPS, was a reflection of the traditional ethnographic interest and desire to protect Africans from modernization by ensuring access to agricultural plots. The amorphous justification for communal labor was shrouded in work and tribe which lay at the kernel of the societies interests in Africa

The impact of both the APS and BFASS upon British colonial policy cannot be measured simplistically in terms of "victories." For in truth as H. C. Swaisland has stated in reference to the APS, "They never turned the Colonial Office from pursuit of British interests."116 A more fundamental factor in assessing the BFASS and APS is the object ${ }^{117}$ of their discourse. Specifically, as we take this up at the end of chapter seven, what role did humanitarian discourse play in the institutional machination of state power in colonial Kenya? It is within this scope that we track the "conscience" of British colonial policy as it wrestled with slavery and the slave trade in East Africa.

${ }^{116}$ H. C. Swaisland, "The Aborigines Protection Society, 1837-1909," Slavery and Abolition 21 (2), (August 2000), 276.

${ }^{117}$ By the object I mean the role that the discourse played in the formulation of European hegemony. Free labor and trusteeship represented the real machination of this humanitarian discourse as European powers grappled with African labor problems. I borrow this understanding of "object" from Louis Althusser and Etienne Balibar, Reading Capital, 47. 


\section{Chapter 3}

\section{Early Humanitarian Protests Against Slavery and The Slave Trade in East Africa}

The rhetorical protests of humanitarian groups against "slavery" in Kenya, in all its forms, had its origins even before the forced labor controversy of 1919. Spurred on by lurid tales of the East African slave trade, ${ }^{1}$ humanitarian organizations like the British and Foreign Anti Slavery Society had been pushing the British government to end the slave trade in East Africa since the mid nineteenth century. The imposition of colonial rule emboldened these organizations to continue petitioning the British government to end slavery on the coast of Kenya.

\section{The East African Slave Trade}

The East African Slave trade evolved around the Indian Ocean basin. Slaves were taken from mainland East Africa and sold in markets in the Middle East and during the nineteenth century on plantations on the East African coast. Unlike the trans-Atlantic slave trade, the East African slave trade to Asia concentrated mostly on women and young boys until it was transformed in the $19^{\text {th }}$ century with the development of the plantation systems on the islands of Zanzibar, Pemba and French islands in the Indian ocean.

${ }^{1}$ The most famous report of slavery in East Africa was from the missionary David Livingstone's travels in the Upper Zambezi and Interlacustrine areas in 1866-73. This became a book Narrative of an Expedition to the Zambesi (New York: Harper and Brothers Publishers, 1866). Livingston traveled widely in Africa and believed that Christianity and commerce would be the only solution to the slave trade in East Africa. His publications were serialized in British tabloids and became very popular with his lurid tales of slavery in East Africa.

$$
\text { Page -54- }
$$


Slave traffic before the $19^{\text {th }}$ century was sporadic and small in volume. ${ }^{2}$ In the $19^{\text {th }}$ century the volume of slave traffic began to rise due to the demand for slaves on plantations on Zanzibar, Pemba, Reunion, Mauritius and Madagascar. The $19^{\text {th }}$ century East African slave trade can actually be delineated into two parts, the southern slave trade and the northern slave trade. In terms of East Africa, humanitarian organizations, like the BFASS, were most concerned about the Northern or Muslim slave trade.

The southern slave trade of East Africa centered around the Portuguese colony of Mozambique. ${ }^{3}$ It fed markets for slaves on the sugar plantations in Brazil, Cuba and the French Islands ${ }^{4}$ in the Indian ocean. Slaves were captured in the hinterland of Mozambique and shipped to entrepots like Quelimane on the Mozambique coast. It is estimated that between 1815 and 1830 , ten thousand slaves were shipped annually to Brazil and another seven thousand annually to French possessions in the Indian ocean. ${ }^{5}$

Capitalist demand influenced French acquisition of slaves, and it eventually began to sap the northern slave trade. By 1770 , three-thousand slaves were traded annually by the French, and they began to encroach on Omani territory to acquire more slaves. In 1776 a French slave trader named Morice signed a treaty with the Sultan of Kilwa to supply 1000 slaves a year. ${ }^{6}$ Following

\footnotetext{
${ }^{2}$ Joseph, Harris, The African Presence in Asia: Consequences of the East African Slave Trade (Evanston: Northwestern University Press, 1971), 5.

${ }^{3}$ Beachey, The Slave Trade of Eastern Africa, 13.

${ }^{4}$ The French islands were Bourbon (Reunion) and Ile de France (Mauritius). The Islands were occupied by the French East India company in 1664 and 1715 respectively. After the Napoleonic wars, Mauritius was transferred to the British in 1814, but Reunion was returned to the French. Ibid., 25

${ }^{5}$ Beachey, The Slave Trade of Eastern Africa, 13.

${ }^{6}$ Nominally, this infringed upon the hegemony of Oman over Kilwa. However, Oman was too powerful as a trading power to be cast aside. 
the Napoleonic period, the French trade declined until a revival in the mid $19^{\text {th }}$ century.

Not surprisingly, there was humanitarian protest against the Southern slave trade. Following the Napoleonic wars, the British assumed control of the French island of Mauritius. With control came blistering attacks from the BFAS criticizing the institution of slavery on Mauritius. ${ }^{7}$

After the "official" close of the British sector of the trans-Atlantic slave trade in 1807 coupled with the end of the Napoleonic era in 1815 , the southern slave trade was bolstered by the French engagé or free labor system. The "free labor" system originated out of an 1842 convention between the Sultan of Oman, Seyyid Said, and the French. Under the convention, the French were permitted to recruit laborers in the Sultan's domains. ${ }^{8}$ But the system of "free emigration" was not so free. During Livingstone's travels, he encountered a group of "free emigres" that were "chained and in large canoes" bound eventually for the island of Réunion. ${ }^{9}$ Free laborers were bought on the main land coast of Mozambique by the French. The slaves were then nominally "freed" and shipped to French possessions like the Comoros or Réunion Island to engage in five year labor contracts. Once their term of labor expired, free laborers were seldom repatriated to their home country. ${ }^{10}$

The northern, or Islamic slave trade, historically fed markets in the Middle East. In the Middle East slaves were shipped to markets on the Arabian peninsula and in the Persian Gulf region. Slaves performed a variety of functions. In southern Iran they worked mainly as farm

\footnotetext{
${ }^{7}$ Beachey, The Slave Trade of Eastern Africa, 30.

${ }^{8}$ Ibid., 32.

${ }^{9}$ Livingstone, Narrative of an Expedition, 429.

${ }^{10}$ Nwulia, Britain and Slavery in East Africa, 32.
}

$$
\text { Page -56- }
$$


laborers. ${ }^{11}$ In other parts of the Persian Gulf region slaves were used as soldiers, concubines, pearl divers and domestic servants.

This northern slave trade to the Persian Gulf peaked in the $18^{\text {th }}$ century and then transformed in the $19^{\text {th }}$ century as it began to supply the labor demands of the clove industry on Zanzibar and Pemba islands off of the coast of East Africa. Humanitarian organizations labeled the slave trade during this era as the "Arab or Muslim" slave trade and attacked it vehemently. European visitors who visited the Zanzibari slave markets popularized this aspect of the Northern slave trade.

The trade in slaves to the Middle East paled in comparison to the amount retained locally in East Africa due to the transformation of the slave sector. ${ }^{12}$ With the exception of the $8^{\text {th }}$ and $9^{\text {th }}$ centuries, Asian demand for East African slaves always remained low owing to the native abundance of cheap labor in Asia. Ralph Austen approximates that between 1830 and 1866 Persian gulf imports of slaves averaged about 3,700-3,100 per annum. ${ }^{13}$ Contrastingly, Austen shows that during the 1860's and 1870's coastal retention of slaves on the East African coast was about 8,855 per year. ${ }^{14}$ In the $19^{\text {th }}$ century the volume of trade to the Middle East was often less than the volume of trade within East Africa. However, slave dhows traveling to the Persian gulf often carried more slaves on average than dhows trading solely in East Africa. These figures

\footnotetext{
${ }^{11}$ Thomas Ricks, "Slaves and Slave Traders in the Persian Gulf," in William Gervase Clarence-Smith, ed., The Economic of the Indian Ocean Slave Trade in the $19^{\text {th }}$ Century (London: Frank Cass, 1989), 65.

${ }^{12}$ Ralph Austen, "The $19^{\text {th }}$ Century Islamic Slave Trade from East Africa (Swahili and Red Sea Coasts): A Tentative Census," in Gervase Clarence-Smith, The Economics, 22.

${ }^{13}$ Ibid., 29. Abdul Sheriff estimates 3000 slave annually from East Africa to the Persian Gulf. Abdul Sheriff, Slaves, Spices and Ivory (Athens: Ohio University Press, 1987), 40.

${ }^{14}$ Austen, “The $19^{\text {th }}$ Century Islamic Slave Trade," 28. The Northern coastal areas of retention were Pemba, Mrima/Pangani, Mombasa, Malindi, Lamu, and Benadir/Somalia. This retention represented slaves shipped from Kilwa or Zanzibar that were exported north and retained as opposed to being ultimately shipped to the Persian Gulf.
}

$$
\text { Page -57- }
$$


contrast with the often inflated exportation figures that anti slavery groups purported for the East African slave trade. For example, one guestimate from the Anti Slavery Reporter listed the export figure as 63,000 slave per year. ${ }^{15}$ Other estimates went as high as 500,000 slaves exported a year.

In addition to the numbers, the details of the East African slave trade were often published by humanitarian organizations. For instance, the Anti-Slavery Reporter frequently printed first hand accounts of slavery in East Africa from European travelers or missionaries. ${ }^{16}$ In addition, the BFASS journal frequently excerpted letters from eye witness or written accounts of slavery and the slave trade in East Africa.

First person accounts gave an intimate portrait of certain heinous aspects of the slave trade. For instance, the sight of captured slaves produced this remark from an officer in the anti slavery naval patrol:

We saw several poor sickly skeletons lying on the deck, evidently dying and much disfigured ... the others were all covered with craw-craw and itch, and were scratching large sores all over them and howling like maniacs for water. ${ }^{17}$

Some of the more famous exposés of the slave trade flowed from the pen of the missionary David Livingstone. The narratives of his expeditions became best sellers with graphic depictions of the ravages of the East African slave trade.

${ }^{15}$ Anti-Slavery Reporter, October 15 1867, 231.

${ }^{16}$ For example, Horace Waller, a missionary and also Lay Superintendent of the Universties Mission to Central Africa, frequently gave accounts of slavery and the slave trade from his experiences traveling with David Livingstone. He would eventually edit Livingstone's Last Journals. Anti-Slavery Reporter, March 30, 1872.

${ }^{17}$ Lieutenant Frederick Barnard, Three Years Cruise in the Mozambique Channel (1848; Reprint, London: Dawson's of Pall Mall, 1969), 42. 
Livingstone's second journey into Africa (1858-1864) covered the upper Zambesi river and the Lake Nyasa (Malawi) area. Livingstone's party included his brother Charles Livingstone and Sir John Kirk who would later become Britain's Consul-General for Zanzibar. The expedition left England on 10 March 1858 and landed on the East African coast in May. Although the stated purpose of the expedition was of a geographical nature, one of Livingstone's ulterior purposes was to extend the virtues of commerce and Christianity in "Darkest Africa." Livingstone dedicated the account of his journey, Narrative of an Expedition to the Zambesi, to Lord Palmerston in hopes that his policy of suppressing slave trade on the West African coast would be applied to East Africa. ${ }^{18}$

It was the East African slave trade that preoccupied Livingstone. His narrative account was meant to expose the horrors of the slave trade and also advance the argument for commerce and Christianity as means of ending the traffic in human cargo in Africa. Livingstone stated, "the result of our observation of the actual working of the slave trade at its source is, that it must prove an insurmountable barrier to all moral and commercial progress." ${ }^{19}$ Specifically, Livingstone advocated that the British develop the cotton industry and buy ivory from the Africans. ${ }^{20} \mathrm{He}$ deduced that this would offer Africans in the interior a monetary alternative to slaving. Livingstone felt that the British could only control the slave trade on the coast by cutting off the trade from the interior. ${ }^{21}$

Besides retarding commercial progress, Livingstone also felt that the slave trade negatively

\footnotetext{
${ }^{18}$ Livingstone, Narrative of an Expedition, 7.

${ }^{19}$ Ibid., 623.

${ }^{20}$ Ibid., 141.

${ }^{21}$ Ibid.
} 
impacted the moral development of both slavers and slaved. Livingstone stated that “. . the degradation of the slave must not only demoralize the master, but probably the master is the loser of the two."22 This not only reflected a fear of moral degeneration but, in the same vein, advocated moral regeneration through outrage inspired by accounts of the atrocities of the slave trade. Moral outrage implied moral superiority. Livingstone's graphic descriptions of the slave trade were meant to produce outrage and calls for action. For example, in the Lake Malawi region Livingstone described the destruction associated with slave raiding.

Those taken out of the country are but a very small section of the sufferers. We never realized the atrocious nature of the traffic until we saw it at the fountainhead. There truly 'Satan has his Seat.' Besides those actually captured thousands are killed and die of their wounds and famine, driven from their villages by the internecine war waged for slaves with their own clansmen and neighbors, slain by the lust of gain, which is stimulated be it remembered always, by the slave purchasers of Cuba and elsewhere. ${ }^{23}$

Livingstone's description of a slave caravan was poignant. Besides, the fact that, many in the caravan were children:

two of the women had been shot the day before for attempting to untie the thongs. One woman had her infants brains knocked out because she could not carry her load and it; and a man was dispatched with an axe because he had broken down with fatigue. ${ }^{24}$

As mentioned earlier, Livingstone's accounts of the slave trade were serialized in the tabloids and created a sensation. Many humanitarian organizations were moved to agitate for the end of the slave trade, as a result. The Anti-Slavery Reporter published many excerpts from his letters concerning the East African slave trade and even published a moving obituary commemorating

\footnotetext{
${ }^{22}$ Ibid., 624.

${ }^{23}$ Ibid., 412-413.

${ }^{24}$ Ibid., 378.
} 
his efforts against the East African slave trade. ${ }^{25}$ Livingstone's moving depictions of the slave trade, would a provide source for sporadic protest against the East African slave trade for the BFASS. However, the ambivalent attitude of the British government towards anti-slavery initiative in East Africa also played a factor in arousing humanitarian outrage.

\section{Abolition and the East African Slave Trade}

Through its informal influence in Zanzibar, Great Britain had been gradually limiting the Muslim slave trade in the Indian Ocean since the 1820 's. ${ }^{26}$ To this end, agreements such as the Moresby Treaty in 1822 and the Hamerton Treaty in 1845 were imposed

upon Zanzibar to gradually limit the trade in human cargo.

The Moresby treaty was named after Captain Fairfax Moresby, the British negotiator for the treaty. It stipulated that the Sultan of Zanzibar's subjects were not to engage in slave trading east of a line drawn from the Cape of Delgado, on the border of present day Mozambique and Tanzania, to a point just East of Karachi in present day Pakistan. ${ }^{27}$ The treaty also allowed British warships the right to seize the dhows of Seyyid Said's ${ }^{28}$ subjects engaged in slave trading. ${ }^{29}$ A British consular agent would also reside at Zanzibar or on the coast of the East African mainland to observe and report infractions of the treaty. ${ }^{30}$

${ }^{25}$ Anti-Slavery Reporter, April 1, 1874.

${ }^{26}$ Nwulia, Britain and Slavery in East Africa, 160.

${ }^{27}$ Moses Nwulia, "The Role of Missionaries in the Emancipation of Slaves in Zanzibar," Journal of Negro History 602 (Apr. 1975): 270.

${ }^{28}$ Seyyid Said was the Sultan of Oman and Zanzibar.

${ }^{29}$ Nwulia, "The Role of Missionaries," 270.

${ }^{30}$ Ibid. 
The Moresby treaty gave Arabs a free hand to trade in slaves west of the line and did not affect the slave trade between Oman and other Muslim nations. It was meant to affect trade with Christian nations. Despite the ethereal goals of the treaty, it was not strictly enforced during the 1820 's and 1830's. ${ }^{31}$ Said claimed suzerainty in his East African domains but exercised little actual political control. He was more accustomed to maintaining economic domination. Consequently, with ephemeral checks on their activities, the slave traders continued transporting slaves to Oman, Madagascar and to French and British possessions in the Indian Ocean. The British, for their part, conveniently overlooked French slave raiding in Said's territories. ${ }^{32}$

As a result of this state of affairs, the Moresby treaty was amended in 1839 . The amended treaty shifted the slave trading boundary more to the west, formally excluding British "protected" states on the Indian subcontinent. ${ }^{33}$ The updated treaty also prohibited the enslavement of Somalis since they were thought to be Caucasoid. ${ }^{34}$

Geopolitics also drove British anti slavery efforts. By 1845, the British were fearful of French incursions on the East African mainland. As a result, the Hamerton treaty ${ }^{35}$ was signed. The new treaty limited slave trading to the interior of East Africa and Said's possessions on the coast.

Like the Moresby treaty, the Hamerton treaty also was ineffectual. First of all, the initial

\footnotetext{
${ }^{31}$ Ibid., 271.

${ }^{32}$ Ibid.

${ }^{33}$ Ibid., 272.

${ }^{34}$ Ibid.

${ }^{35}$ It, actually, went into effect on 1 Jan 1847. It was named after Captain Atkins Hammerton. He served on Zanzibar as Britain's consul until his death on 5 July 1857.
} 
treaty had no clause for adjudication of captured slave vessels. ${ }^{36}$ Although this was rectified on 15 September 1848, between 1845 and 1848 the British had to simply release captured slave ships. This gave the impression that the treaty had no teeth. Another problem with the treaty was that its jurisdiction of search and seizure, by British warships, did not extend to the coast between Kilwa and Cape Delgado. ${ }^{37}$ This gave slave traders a buffer zone to trade with impunity. Although the Sultan passed decrees limiting the slave trade, he could not enforce them. ${ }^{38}$ Many Arab dhows sailed under different flags, such as that of the French, to avoid capture. ${ }^{39}$ The vaunted anti slavery patrol of the Royal Navy in East Africa never had more than six ships, with three active, at all times, to patrol the vast 6,000 square miles of the African litoral. ${ }^{40}$

Moses Nwulia states that, except for the time period 1849-1851, the British did not make a concerted effort to limit the East African slave trade. ${ }^{41}$ After 1862, however, the British refocused on the East African slave trade. In 1869 Lord Clarendon, the Foreign Secretary, appointed a committee to look into the East African slave trade and recommend measures for its suppression. ${ }^{42}$ The Clarendon Committee submitted its findings on 25 January 1870 and made a number of recommendations for the suppression of the trade. ${ }^{43}$. In its report, the Committee

\footnotetext{
${ }^{36}$ Beachey, The Slave Trade of Eastern Africa, 53.

${ }^{37}$ Ibid., 54.

${ }^{38}$ Ibid., 58.

${ }^{39}$ Ibid., 78.
}

${ }^{40}$ Ibid.,71. Initially patrol was left up to the Cape of Good Hope station and the Indian Navy Headquarters at Bombay.

${ }^{41}$ Nwulia, "The Role of Missionaries,” 273.

${ }^{42}$ Beachey, The Slave Trade of Eastern Africa, 99.

${ }^{43}$ Ibid., 
found that the slave trade was mostly confined to the Sultan of Zanzibar's territory. To

effectively weaken the slave trade, the Committee called for better and more reliable interpreters, better strategic positioning of ships and the use of lighter, smaller ships on the shore. ${ }^{44}$

Significantly, the Committee did not call for an end to the slave trade. It felt that the termination of the trade would wreck Zanzibar economically. ${ }^{45}$ Instead, the committee advocated using Dar es Salaam as an entrepot to control and gradually limit the slave trade.

In the wake of the Clarendon Committee report, a Select Committee was appointed on 6 July 1870 to further delve into the East African slave trade. ${ }^{46}$ The Committee sat from July 1870 till August 1871 under the chairmanship of Russell Gurney. It heard evidence from many witnesses concerning the East African slave trade. Most of the witnesses were officials in the Foreign Office or former consuls for Zanzibar. ${ }^{47}$

The Committee findings ${ }^{48}$ were similar to those in the Clarendon report, however, its

$$
\begin{aligned}
& { }^{44} \text { Ibid. These recommendations hit at the heart of the problems of the British anti slavery } \\
& \text { naval patrol. } \\
& { }^{45} \text { These same arguments would be used by the Foreign Office and Colonial Office in } \\
& \text { dealing with the problem of slavery on mainland Kenya following the assumption of British rule. } \\
& { }^{46} \text { Beachey, The East African Slave Trade, } 101 .
\end{aligned}
$$
Rigby actually proposed that the British take over Zanzibar as a way of stopping the slave trade. They also heard evidence from the former governor of Bombay Bartle Frere. Frere made such an impression on the Committee that he was eventually appointed to secure the 1873 treaty with Zanzibar ending the slave trade by sea. David Livingstone, also cast his shadow on the proceedings for the Select Committee used as evidence information garnered from his despatches of 1871 to Lord Clarendon.

${ }^{48}$ Ibid. The Select Committee discovered that many slaves were passed off as domestic servants or part of the crew when dhows were boarded by the anti slavery patrol. Without reliable interpreters the naval patrol would have difficulty discerning the difference. The Committee also found that there were problems with jurisdiction. Naval patrols could not scuttle dhows until they were adjudicated in an admiralty court which might be some distance away.

$$
\text { Page -64- }
$$


recommendations differed. The Select Committee proposed five recommendations to stop the slave trade:

- It proposed the appointment of an assistant political agent to assist the Consul at Zanzibar in matters pertaining to the slave trade.

- It called for a new slave trade treaty with Zanzibar.

- Increased regularization of naval patrols, the use of strategic naval squadron steam launches from inshore duty and also the dissemination of better information to officers in the naval squadron.

- The establishment of regular steamship communication between Zanzibar and the Seychelles to offset the French.

- The inclusion of France, USA, Portugal, Persia and Germany in suppressing the slave trade. ${ }^{49}$

The call for a new slave trade treaty with Zanzibar resulted in Sir Bartle Frere' ${ }^{50}$ mission to Zanzibar on 21 November 1872. On 5 June 1873, after much negotiation and intimidation, Sultan Seyyid Bargash of Zanzibar ${ }^{51}$ passed a decree ending the slave trade by sea. ${ }^{52}$ The text of his proclamation stated that:

To all our subjects who may see this, and also to others, may God save you. Now that we have prohibited the transport of raw slaves by sea in all out harbors and have closed the markets which are for the sale of slaves throughout all our

${ }^{49}$ Beachey, The East African Slave Trade, 103.

${ }^{50}$ Frere was closely allied with the BFASS and had given several talks on the subject of slavery and the slave trade for the organization.

${ }^{51}$ Seyyid Said died in 1856. One of his sons, Seyyid Majid, then ruled until 1870 when Bargash assumed control.

${ }^{52}$ The 1873 decree made it illegal to export slaves from the coast of the mainland to Said,s possessions. Ibid. 
dominions. Whosoever, therefore, shall ship a raw slave after this date will render himself liable to punishment and this he will bring upon himself. Be this known. ${ }^{53}$

Despite the tough wording, the treaty was weak. Slave traffic merely diverted to land routes. One contemporary witness noted that after the decree in 1873 the slave traffic merely moved along the coast from Pangani in the interior to Kilwa and from there to Tanga. At Tanga the slave traders shipped the slaves to the island of Pemba. ${ }^{54}$ The vast East African coastline coupled with a dirth of British cruisers, ensured that the British only intercepted roughly 3 percent of the traffic. ${ }^{55}$

To many anti-slavery advocates, the British approach to enforcing anti slave-trade measures appeared to be diffident. This evoked a frustrated remark from chaplain J. R. Farler, a missionary of the Magilla Mission on the East African coast and future Slavery Commissioner for Pemba: "The whole thing is a farce as now carried on, we bully the sultan but do precious little to help him now." 56 Bargash eventually issued a proclamation on 18 April 1876 declaring the slave trade by land illegal. However, since he had no power to enforce the proclamation, the effect was nugatory. And, as Joseph Chamberlain would note much later in a confidential

${ }^{53}$ Quoted in Beachey, East African Slave Trade, 113.

${ }^{54}$ J. R. Farler to Bishop Sture, Head of The Magila Mission, 13 March 1877, Box G2/A, Papers of the British and Foreign Anti-Slavery Society and Aborigines Protection Society, Rhodes House Library, Oxford.

${ }^{55}$ J. R. Farler to Aborigines Protection Society, 15 Jan 1877, Box G2/A, Papers of the British and Foreign Anti-Slavery Society and Aborigines Protection Society, Rhodes House Library, Oxford. Colonel Rigby, Hamerton's successor as British consul for Zanzibar (18581861), submitted even more dismal figures. He approximated that only 1 percent of slaves taken north from Said's domains in East Africa were actually captured by cruisers.

${ }^{56}$ J. R. Farler to Aborigines Protection Society, 15 January 1877, Box G2/A, Papers of the British and Foreign Anti-Slavery Society and Aborigines Protection Society, Rhodes House Library, Oxford. 
memorandum, Sultan Bargash's edict abolishing slavery was, essentially, not meant to have emancipation intent. ${ }^{57}$

The gradualist process that began in 1822 with the signing of the Moresby treaty finally culminated in formal decrees prohibiting the sale, exchange and purchase of slaves on 1 August $1890 .{ }^{58}$ However, the illegal trade in slaves continued to $1899 .{ }^{59}$ In addition, the decree of 1890 was not enforced until 1896; it was also kept secret.

Although it could be argued, in regards to anti-slavery initiative, that Great Britain was " the main instrument in the hands of providence." ${ }^{60}$ Its approach to ending the East African slave trade reflected a deeper commitment to political and economic factors. The British were more concerned about the economic impact that an abrupt cessation of the East African slave trade would have upon Zanzibar. This, in turn, would affect Zanzibar's diplomatic role. ${ }^{61}$ In essence, the British used Zanzibar's tenuous autonomy to offset French influence in the Indian ocean on the cheap.

\section{The BFASS and the East African Slave Trade}

${ }^{57}$ Joseph M. Chamberlain, Confidential, 12 September 1895, CAB /37/40/45.

${ }^{58}$ The conclusion of the Anglo German Act of July 1890 made Zanzibar a protectorate of Great Britain. This effectively ended Zanzibar's autonomy and forced the Sultan to sign the decree. The decree of 1890 also emancipated slaves whose masters had died but left no heirs; slaves who married British subjects and slaves owned by former slaves. Nwulia, "The Role of Missionaries," 279.

${ }^{59}$ Nwulia estimates that the export of slaves did not actually end until 1899. Ibid., 274.

${ }^{60}$ Lord Palmerston to Bombay Government, 6 December 1846, quoted in R. W. Beachey, The Slave Trade of Eastern Africa: A Collection of Documents (New York: Harper, 1976), 19.

\footnotetext{
${ }^{61}$ Nwulia, Britain and Slavery in East Africa, 42.
} 
This winding pace of diplomatic abolition frustrated many humanitarian groups like the BFASS. As mentioned previously, petitioning governments through memorials and publications in the press was one of the main tactics of the BFASS. The Society sent numerous memorials concerning slavery and the slave trade to various foreign potentates and to the assorted Foreign Secretaries of the British government. Indeed, the memorials not only revealed the Society's fervent abolitionism but, on occasion, the contradictory imperial face of anti slavery ideology in Africa.

In 1875, when Sultan Bargash of Zanzibar made a trip to London, a deputation from the British Foreign and Anti-Slavery Society met him and petitioned him to end slavery on the mainland of his dominions. ${ }^{62}$ The Society echoed a similar call to action in an earlier memorial to the Emperor of Germany on 17 September $1872 .{ }^{63}$ In this memorial, the British Foreign and Anti-Slavery Society lamented the loss of two hundred thousand lives, annually, to Arab slavers and implored the emperor to extend legitimate trade in Germany's East Africa territories. ${ }^{64}$

In a memorial to the Khedive of Egypt, Ismail Pasha, in 1873, the BFASS implored him to end slavery in his domains, in particular the newly conquered Sudan, and decried his past ephemeral attempts to end the trade. A follow up memorial, printed in the Anti-Slavery

62،"Slavery in the British Protectorates of Zanzibar" in Slavery in British Protectorates: Memorials of the British and Foreign Anti-Slavery Society and other Documents Connected with Slavery and the Slave Trade in the Sultanate of Zanzibar(London: British and Foreign Anti-Slavery Society, 1897).

63،"Territorial Section, 20 ${ }^{\text {th }}$ Century: British East Africa," Box G2/A, Papers of the British and Foreign Anti-Slavery Society and Aborigines Protection Society, Rhodes House Library, Oxford.

${ }^{64}$ This was predicated upon the Society's assertion that since German trade in East Africa was extensive it would be easier to extend the so called "legitimate trade" in other staples to offset the demand for human labor. 
Reporter, applauded Sir Samuel Baker, Governor General of Equatoria Province of Egypt, for attempting to quell slave raiding in the lower Nile Valley region. ${ }^{65}$ Much later in 1890, after Great Britain had assumed control of Egyptian affairs, Joseph Chamberlain would wax eloquent about ". . the Augean stables which England had to reclaim. .." in Egypt. ${ }^{66}$ However, these attempts to quell slave raiding threatened the autonomy of certain kingdoms in the region. ${ }^{67}$ At the conclusion of the Anglo-German Agreement of 1890, which, in effect, made Zanzibar a protectorate of Great Britain, the BFASS lauded the British government in a memorial to Marquis of Salisbury:

The Anti-Slavery Society regards the assumption of an English Protectorate over Zanzibar and Pemba as a step of the highest importance in obtaining the suppression of the maritime Slave traffic, and the extirpation of Slavery itself, for which England has so long striven. ${ }^{68}$

For the BFASS commerce and free labor underpinned any strategies for ending the East African slave trade. A memorial to the members of Parliament, "Supplanting of the Slave Trade By Legitimate Commerce," echoed these themes. In the memorial the BFASS assumed that the spread of legitimate commerce would bring "civilization" and lead to a decline of the slave trade. As evidence, they cited the case of Zanzibar, which, according to the BFASS, had nearly doubled

${ }^{65}$ Anti-Slavery Reporter, October 1, 1873.

${ }^{66}$ Ibid., March and April, 1890, 66.

${ }^{67}$ For example, Baker's attempts to stop slave raiding enfringed on the sovereignty of the kingdom of Bunyoro-Kitara. Under its famous leader Mukama (king) Kabarega, Bunyoro was able to resist, but his capital was burned by James "Chinese" Gordon. Baker was part of a coterie of Europeans employed by the Khedive of Egypt in his efforts to modernize. Robert Maxon, East Africa: An Introductory History (Morgantown: West Virginia University Press, 1994), 128.; M. S. M. Kiwanuka, History of Buganda: From the Foundation of the Kingdom to 1900 (New York: Africana Publishing Corporation, 1972), 160.

${ }^{68}$ Anti-Slavery Reporter, July and August, 1890, 145. 
its trade after the abolition of the slave trade there. ${ }^{69}$ On an ancillary note, ironically, after the imposition of British rule in the East Africa Protectorate, the state and the settlers would make an opposite argument concerning the benefits of free labor: since "the African is essentially a child" he would not respond to higher wages. ${ }^{70}$ The benefits of wage labor would then have to be imposed. This implied that an element of force, emanating from the state, was necessary to make the Africans work, and, seemingly, contradicted the ideal of free labor.

The BFASS also proposed practical applications of the efficacy of free labor and commerce. As early as September 7, 1838, T. F. Buxton wrote a letter to his friend Lord Gleneld in the British Cabinet proposing that the British assume control of the island of Mombasa and turn it into "commercial settlement." crude idea" by Palmerston, the Foreign Secretary. ${ }^{72}$ However, the idea did not die.

A commercial settlement also underpinned ideas of creating a so called "Liberia on the East Coast" of Africa as a way of checking the slave trade and proctoring British influence, vicariously. ${ }^{73}$ In March 1877, Gerald Waller of East African Expeditions delivered a letter to T. F. Buxton which contained an interesting draft of certain business concessions to be proposed to the Sultan of Zanzibar for the eventual suppression of the slave trade. ${ }^{74}$ The draft concession

\footnotetext{
${ }^{69}$ Ibid.
}

${ }^{70}$ Sir Charles Eliot to Marquis of Landsdowne, July 1903, in Great Britain, Report on Slavery and Free Labour in the British East Africa Protectorate, cmd. 1631 (July 1903).

${ }^{71}$ Nwulia, "The Role of Missionaries in the Emancipation of Slaves in Zanzibar," 269.

${ }^{72}$ Ibid. Palmerston was Henry John Temple, $3^{\text {rd }}$ viscount.

${ }^{73}$ J.P. Farler to Bishop Sturge, 15 January 1877, Box G2/A, Papers of the British and Foreign Anti-Slavery Society, Rhodes House Library, Oxford.

${ }^{74}$ Gerald Waller to Thomas Fowell Buxton, 8 March 1877, Box G2/B, Papers of the British and Foreign Anti-Slavery Society, Rhodes House Library, Oxford.

$$
\text { Page -70- }
$$


called for the occupation of the Lake Victoria and Nyanza regions in the Sultan's name to check the spread of the Egyptian government. When Buxton visited Zanzibar, he forwarded the plan to the Sultan through the British Consul at Zanzibar, Sir John Kirk, but nothing came of it.

On the international level, humanitarian initiative against the slave trade was also effervescent. As mentioned previously, in 1867 the BFASS convened an international anti slavery convention in Paris. The convention was significant for it focused attention on the East African slave trade. At the convention Horace Waller, who had accompanied Livingstone in East Africa, "produced a profound sensation" with his eye witness accounts of the East African slave trade. $^{75}$

At the Berlin West Africa Conference of $1884-1885$, the BFASS raised the question of the slave trade in East Africa in a memorial to Bismarck. ${ }^{76}$ It also urged the British Foreign Secretary, Lord Granville, to ensure that safeguards against the slave trade were written into the Berlin Act and tried hopelessly to get him to put the topic of engagé labor on the agenda of the conference. $^{77}$

In terms of humanitarian issues, the liquor traffic was of more concern at the Berlin Conference than the slave trade. ${ }^{78}$ However, the signatory powers made an amorphous commitment to end the slave trade and slavery within their respective territories in Central

${ }^{75}$ Anti-Slavery Reporter, September 16, 1867, 205.

${ }^{76}$ Beachey, The Slave Trade of Eastern Africa, 220.

${ }^{77}$ Suzanne Miers, Britain and the Ending of the Slave Trade (New York: Africana Publishing Company, 1975), 171, 173.

${ }^{78}$ The liquor trade in Africa was seen by many humanitarian organizations like the APS as an impediment to the spread of civilization in Africa. This belief was a reflection of ethnocentric notions that Africans were more prone to drunkenness than Europeans, and that many of the problems in Africa were caused by the consumption of alcohol. Miers, Britain and the Ending of the Slave Trade, 174. 
Africa. The General Act of the conference specifically outlawed the maritime slave trade according to the impotent dictates of international law. ${ }^{79}$ Article Nine obligated the signatories to prevent their territories in the conventional basin of the Congo from being used as markets for slave trading. However, since these measures lacked any enforcement structure their net effect was limited. Ironically, as L. H. Gann has mentioned, the implicit effect of the Article 9 was to ultimately advance European colonial expansion by basically declaring war against the Swahili in the region who dominated the slave trade in the Congo basin. ${ }^{80}$

The Brussels conference of 1889-1890 was more humanitarian in nature than the Berlin Conference because it introduced "native welfare" as an international responsibility. ${ }^{81}$ The conference was nominally convened to protect Africans from the evils of the liquor, arms and slave trade. The Brussels conference was more significant for BFASS since it had an indirect part in its organization. ${ }^{82}$ Consequently, it campaigned to place the slave trade of East Africa as the number one topic on the agenda for the conference. A deputation from the BFASS at the conference supplied a large map which detailed the slave trade routes of the interior of East Africa. In addition, the deputation of the BFAS displayed a slave yoke for the members of the conference.

\section{${ }^{79}$ Miers, Britain and the Ending of the Slave Trade, 172.}

${ }^{80}$ L. H. Gann, "The Berlin Conference and the Humanitarian Conscience," in Stig Förster, Wolfgang Mommsen, and Ronald Robinson, eds., Bismarck, Europe and Africa: The Berlin Conference 1884-1885 (London: Oxford University Press, 1988), 325.

${ }^{81}$ Suzanne Miers and Martin Klein, eds., Slavery and Colonial Rule in Africa (London: Frank Cass, 1999), 19.

${ }^{82}$ Sydney Buxton an MP and spokesman for the BFASS in the House of Commons brought forward a motion on 26 March 1889 calling for an anti slavery conference. The motion was unanimously accepted. 
In a memorial to the Marquis of Salisbury ${ }^{83}$, the Foreign Secretary, the BFASS stated that since, "the liquor traffic is in no way connected with the Slave-trade on the East Coast of Africa," suppression of the slave trade should be the number one agenda. ${ }^{84}$ On 13 February 1890 in the House of Commons, Sydney Buxton repeated the BFASS opinion to the Under Secretary of State for Foreign Affairs, J. Ferguson, emphasizing that “. . .the question of the liquor trade is one affecting the West Coast of Africa ... whereas the question of the Slave-trade is one affecting the East Coast." ${ }^{\prime 55}$ The BFASS had a latent fear that if an issue like the liquor traffic was addressed first, it would become, as during the Berlin Conference, mired in arguments over trade rights in Africa.

In addition, the Society felt that the second agenda should address the legal status of slavery in the dominions of the Sultan of Zanzibar. ${ }^{86}$ In another memorial to the Secretary of State for Foreign Affairs on 25 March 1890 the BFASS lamented that the previous anti slavery decrees involving Zanzibar had been so called "dead letters. ${ }^{\circ 7}$ Consequently, the BFASS hoped that ". . . pressure will be brought to bear upon the Zanzibari authorities ...” to effect proclamations against the slave trade. BFASS hopes were soon realized when Great Britain assumed a protectorate over Zanzibar in on 1 July 1890.

The aggressive tone of the Society's memorial was based upon an erroneous belief that the Sultan of Zanzibar would be represented at the Conference. A reply from the Foreign Office on

\footnotetext{
${ }^{83}$ Robert Cecil, $3^{\text {rd }}$ Marquis.
}

${ }^{84}$ Anti-Slavery Reporter, January and February, 1890, 8.

${ }^{85}$ Great Britain, Parliamentary Debates, 3d ser., Vol. 341 (1890), col. 209.

${ }^{86}$ Miers and Kline, Slavery and Colonial Rule, 19.

${ }^{87}$ Anti-Slavery Reporter, March and April, 1890, 53. 
14 April 1890, assured the Society that “. . . the Sultan of Zanzibar is represented at the conference at Brussels and will, presumably, be a party to its decisions, involves a new departure." 88 The "new departure" would actually become joint British and Germany representation of Zanzibar's interests at the conference. ${ }^{89}$

The articles of the General Act of the Brussels conference dealt with many aspects of the East African slave trade. These aspects included: anti-slavery measures in points of origin, caravan routes of slaves, repression of maritime slave trade, regulations concerning the use of flags, protection of liberated slaves, the stopping of suspected slave vessels and so forth.

Despite the emancipatory ideals of the conference, the resolutions that were passed maintained a political countenance. ${ }^{90}$ Effective transformation of an area for the purposes of stopping the slave trade, covered under article one, meant occupation and the establishment of an administrative apparatus. In effect, anti-slavery meant the establishment of colonial administrations in the interior of Africa. ${ }^{91}$

The maritime clause in the general act of the conference, that permitted mutual search of ships, only applied to the Red Sea, Persian Gulf and parts of India. In addition, it only applied to "small vessels."92 Although article sixty four established bureaus in Brussels and Zanzibar for shepherding information about the slave trade, the lack of enforcement structure crippled the Act

${ }^{88}$ Ibid., 54.

${ }^{89}$ Sir John Kirk, British Consul for Zanzibar, Represented the British side while Dr. von Arendt, a former Consul-General in Zanzibar, served as the German intermediary. Miers, Britain and the Ending of The Slave Trade, 232.

${ }^{90}$ Miers and Klein, Slavery and Colonial Rule, 19.

${ }^{91}$ Suzanne Miers, "Slavery and the Slave Trade as International Issues, 1890-1939" Slavery and Abolition 19(2) August 1998, 19.

${ }^{92}$ Ibid. 
and created a major loophole. ${ }^{93}$ Only through publicity and protest could the slave trade be limited, for the Brussels act did not bind the signatories to suppress the slave trade. ${ }^{94}$ None of the European countries that signed the document were willing to go that far. This, seemingly, left the job of enforcement up to humanitarian organizations like the BFASS.

As Suzanne Miers Oliver has noted, between 1892 and 1914, many European countries took steps to end slave raiding in their territories. ${ }^{95}$ However, they did not take up the mantle of ending slavery itself which continued in some regions of Africa under colonial rule well into the twentieth century. This negligence was purposeful. Slave raiding destabilized colonial rule and provided a facile justification for domination while, the institution of slavery in some instances fortified colonial rule.

Following the Brussels Conference, Cardinal Lavigerie, founder of the "White Fathers"96 missionary association, convened an anti-Slavery conference in Paris on 22 September 1890. The White Fathers had established missions around the Lake Victoria region in East Africa and were active against the East African slave trade. The delegates to the conference came from various anti slavery organizations around Europe. Charles Allen represented the BFASS. The Paris Conference was convened after the Brussels Conference to ride the momentum of anti

\footnotetext{
${ }^{93}$ After the Brussels Act, British slave trade papers, which formerly had been published as parliamentary papers, were sent to the maritime bureaus. The BFASS made use of the information housed at the Zanzibar bureau.

${ }^{94}$ Miers, "Slavery and the Slave Trade," 19.

${ }^{95}$ Ibid., 21. This theme of the ending of slavery in Africa is dealt with in depth by Suzanne Miers and Richard Roberts, eds., The End of Slavery in Africa (Madison: University of Wisconsin Press, 1988).

${ }^{96}$ They were also known as the Society of the Missionaries of Our Lady of African Missions. Lavigerie founded the White Fathers in 1868-69 at Algiers, ostensibly to establish missions in East and Central Africa. Kiwanuka, History of Buganda, 170.
} 
slavery ideology.

The resolutions passed at the conference were intended to assist the various signatories of the Brussels conference in their efforts against slavery and the slave trade in their respective territories. The tone of the resolutions was intended to reinforce the anti slavery theme of the conference. However, the proposals also brought about some differences with the BFASS.

Originally, the proposal for the first resolution called for anti slavery work in Africa to be compartmentalized according to the national origin of the specific anti slavery national committee. ${ }^{97}$ This drew the criticism of the BFAS which objected to this implied limitation of their anti slavery activities. ${ }^{98}$ The resolution was eventually made more vague so as to be interpreted individually.

The original proposal for the third resolution contained militaristic content. It called for the "formation of bodies of volunteers" to be offered to each national committee. This proposal mirrored an earlier idea of Cardinal Lavigerie's which called for the formation of Christian volunteers to go to the western shores of Lake Tanganyika and fight the slave trade. ${ }^{99}$ The BFASS was a pacifist organization and objected to all measures which entailed military force. The final resolution was changed to reflect that "the congress relies, above all upon pacific measures." 100

The original proposal for resolution 6 called for an examination of the issue of free labor with regards to protecting "the interests of the European Colonists, and to the freedom of the

\footnotetext{
${ }^{97}$ The whole text of the resolutions was printed in the Anti Slavery Reporter. AntiSlavery Reporter, September and October, 1890, 216.
}

${ }^{98}$ Ibid., 213.

${ }^{99}$ Miers, Britain and the Ending of The Slave Trade, 206.

${ }^{100}$ Anti-Slavery Reporter, September and October, 1890, 217. 
blacks."101 The final resolution was reworded to focus more upon the abuses associated with free labor, and it called for more safeguards for black free labor in the market place.

Notwithstanding the "clerical character" of the conference, the BFASS was in full accord with most of the aims of the Paris anti slavery congress. The timing of the Paris conference gave many anti slavery and "native" welfare organizations a boost. This boost was more than just ideological and moral gain. The BFASS literally profited from Lavigerie's anti slavery cause. ${ }^{102}$

Before the 1890s there was trail of protest against the East African slave trade. However, during the 1890s humanitarian protest against the East African slave trade dramatically increased, and it is during this time period that the BFASS became most active against trade in slaves.

British attacks upon the Arab slave trade were more political than humanitarian. Similarly BFASS critiques of British policy regarding the East African slave trade reflected a deeper ideological current. The East African slave trade was an abhorrence which produced humanitarian outrage against the traffic. In its critiques of slavery in East Africa, the BFASS was following the anti slavery tradition of the $18^{\text {th }}$ century. For organizations like the BFASS, slavery had been bounded historically, first in 1807 and later in 1833. It had been excised and was no longer an acceptable form of labor organization. Its appearance in the late $19^{\text {th }}$ century in East Africa was an anathema to the humanitarian lobby. Of course, this phenomenon of slavery in East Africa could be attributed to kleptocratic African chiefs or to, as Horace Waller stated, the

${ }^{101}$ Ibid., 218.

${ }^{102}$ The BFASS received 50,000 francs from Cardinal Lavigerie. BFASS, A Summary of the Work of the British and Foreign Anti Slavery Society (London: BFASS, 1900), 63.

Page -77- 
"yellow man" in Africa. ${ }^{103}$ For the BFASS, however, British association with the East African slave trade represented a step back.

The foundation of the organization was built upon an opposition to slavery and the slave trade, but also it was built upon a proposition of the benefits of free labor. The efficiency of free labor over slave labor was an assumption of the Society that was continuously disproved in East Africa. As such, free labor had to be won and was the undercurrent of BFASS advocacy of anti slavery in East Africa.

${ }^{103}$ Horace Waller in a speech to the Ministers of Religion in Liverpool on October 18, 1894 discussing The role of Great Britain and slavery and the slave trade in Africa. Anti-Slavery Reporter, September and October, 1894, 270. 


\section{Chapter 4}

\section{Slavery in the EAP: Humanitarian Protest}

Before the 1890s there was trail of protest against the East African slave trade from humanitarian organizations like the BFASS. However, during the 1890s humanitarian protest against the East African slave trade dramatically increased, and it is during this time period that the BFASS became most active against trade in slaves and slavery. Utilizing some of the same techniques from previous slavery controversies the BFASS petitioned the British government, wrote officials, and organized conferences in their efforts to change policy on slavery and the slave trade.

With the assumption of formal British influence in East Africa after 1890, first under the Imperial British East Africa Company (IBEAC) and later the Foreign Office, British involvement with slavery in East Africa juxtaposed against the ideals of its anti-slavery initiatives became more contradictory, but apparent. Historically, Britain had used Zanzibar as a proctor for political and diplomatic influence in the Indian Ocean since the Moresby treaty in 1822 . In essence, the British used anti slavery ideology, through Zanzibar, as a cheaper way of promoting political and diplomatic influence in East Africa and the Indian Ocean basin. However, when Germany entered the diplomatic arena in East Africa during the 1880's, this byzantine pace of diplomacy came to a halt and signaled the end of Britain's "informal empire" on the East African coast and the beginning of dejure colonialism in East Africa. ${ }^{1}$ Between 1880 and 1895 Britain and Germany divided up East Africa into Spheres of influence.

In November 1884 Karl Peters, founder of the imperialist German Society for Colonization,

${ }^{1}$ Nwulia, Britain and Slavery in East Africa, 160.

Page -79- 
landed in Zanzibar and proceeded to the hinterland of the East African coast where he obtained several dubious treaties of "protection" from various "chiefs." Although Peters imperialist initiative was done without the encouragement of the German government, his efforts, none the less, were used as the justification for an eventual German protectorate in East Africa. In 1886 Germany and Britain signed an agreement splitting up East Africa into spheres of influence. ${ }^{2}$ The agreement defined the territorial extent of Zanzibar including Zanzibar proper and the islands of Pemba, Mafia and Lamu. It also gave the Sultan of Zanzibar control of a ten mile deep coastal strip of land between the Tana river and the Ruvuma river in modern day Kenya and Tanzania respectively. The mainland behind the coastal strip was divided up also. Great Britain received the territory roughly comprising modern Kenya while Germany received the territory essentially constituting modern Tanzania. A later treaty on 1 July 1890 extended British influence to include modern Uganda and, significantly, declared Zanzibar a British Protectorate. ${ }^{3}$ Initially, both Great Britain and Germany manifested their political influence through chartered companies. The IBEAC was responsible for administration of British territories while the Society for German Colonization played a similar role for the Germans. Although the Sultan of Zanzibar nominally controlled the ten mile deep strip of territory on the coast, it was leased to both the IBEAC and the Germans. Slavery existed in both the islands of the Sultan's domains and on the mainland. Consequently, the IBEAC inherited the problem of slavery in East Africa and then transferred to the British government in 1895.

When the IBEAC assumed its charter in East Africa, slavery and the slave trade were

${ }^{2}$ G. H. Mungeam, British Rule in Kenya, 1895-1912 (Oxford, Clarendon Press, 1966), 1.

${ }^{3}$ Ibid.; Maxon, East Africa, 134. This treaty was called the Heligoland treaty since the Germans received Heligoland Island in the North Sea in exchange. A protectorate was later declared over Buganda in 1894 and basically extended to the rest of modern Uganda in 1896.

$$
\text { Page -80- }
$$


entrenched in the society. Many of the Arab rulers on the coast, like the Mazrui governors on the mainland, owned many slaves and were heavily involved in trading slaves themselves. Despite this fact, as Fred Morton has noted, the IBEAC was never committed to ending slavery in its coastal territories. ${ }^{4}$ Instead, the company focused on a strategy of gradual amelioration of slavery. The need for labor in East Africa was too great and the company had a vested interest maintaining a stable labor force.

Initially, when the IBEAC took control, it made a symbolic gesture by releasing 1421 fugitive slaves of the Church Missionary Society (CMS) station at Rabai on the coast. ${ }^{5}$ Fugitive slaves and maroon societies had been a problem on the coast. ${ }^{6}$ British Missionary societies exacerbated the political situation by taking in runaway slaves. ${ }^{7}$ This irked slave holders. For example, as early as 1876 and 1879, Arab and Giriama slave holders had actually taken measures to attack mission stations that were holding runaway slaves.

Although the IBEAC initially released the Rabai slaves, most of whom were hired by the company, its policy, thereafter, was to return all runaways and fugitive slaves. The reason for this policy was found in the company's relationship with the ruling Arab political structure. The

\footnotetext{
${ }^{4}$ Fred Morton, Children of Ham: Freed Slaves and Fugitive Slaves on the Kenya Coast, 1873 to 1907 (Boulder: Westview Press, 1990), 137.
}

${ }^{5}$ Ibid.

${ }^{6}$ On this subject, besides Morton also see Abdul Sheriff, Slaves, Spices and Ivory in Zanzibar; Frederick Cooper, From Slaves to Squatters: Plantation Labor and Agriculture in Zanzibar and Coastal Kenya (New Haven: Yale University Press, 1980; Cynthia Brantley, The Giriama and Colonial Resistance in Kenya, 1800-1920 (Berkeley: University of California Press, 1981); C. S. Nichols, The Swahili Coast: Politics, Diplomacy and Trade on the East African Litoral (London: George Allen and Unwin, 1971).

${ }^{7}$ Nwulia, Britian and Slavery in East Africa, 170. Ironically, missionary activities regarding fugitive slaves were in keeping with the Brussels Act which allowed European powers the right to keep fugitive slaves.

$$
\text { Page -81- }
$$


brief IBEAC rule in East Africa was tenuous and fraught with financial difficulties. The company needed the support of the ruling Arabs on the coast, who were also the main slave holders and slave dealers. Most of the Arab liwalis or governors were allies of the Company; however, two powerful Mazrui rulers, Mbarak bin Rashid of Gasi and Salim bin Khamis of Takuanga on the coast were problematic for the company. ${ }^{8}$ Consequently, the company could not maintain policies which weakened slavery on the mainland, and it could not enforce them, anyway, against such powerful recalcitrant chiefs . Only in Mombasa did the company make a concerted effort to apply the anti slavery decree of 1890 which forbid the sale of slaves. ${ }^{9}$ The IBEAC actually attempted to assuage Mbarak by putting him on the company payroll. ${ }^{10}$

Acquiring labor, was another issue that influenced the company's slavery policy. In East Africa, porters were the main means of transport. As a result, there was a constant demand for porters that could not be met by wage employment. Although numerous upcountry porters worked for wages, many porters were actually slaves. The company needed a stable labor force as much as the local Arabs. So, in this instance, anti slavery policies went against the interests of both the company and the Arabs. The IBEAC itself was quite active in hiring slave porters and, actually, had a contract with Salim bin Khamis of Takaunga on the East African coast for the supply of slave porters. ${ }^{11}$

The IBEAC thus had an interest in maintaining slavery at a slow pace of diminution. On 15

${ }^{8}$ Morton, Children of Ham, 146. The simmering problem of the Mazrui discontent against both the British and the Busaidis would finally come to the surface in the 1895 AngloMazrui war after the British assumed a formal protectorate over East Africa.

${ }^{9}$ Morton, Children of Ham, 138.

${ }^{10}$ Ibid., 120. Mbarak was paid 1,940 rupees per month.

${ }^{11}$ Ibid. 132. 
May 1890 one MP, Sir George Campbell, asked, the Under Secretary of State whether the IBEAC had actually abolished slavery in the territories under its influence. ${ }^{12}$ Sir John Ferguson, the Under Secretary was forced to admit that "it is understood that the proclamation does not affect the status of slavery as now existent." ${ }^{13}$ Contrary to the rhetoric of humanitarian organizations like the BFASS, wage labor was not proving more efficient than slave labor. The company resigned itself to the "problem" of slavery under a British flag.

As reflected in the IBEAC actions, aside from the effects of anti slavery ideology, for most of the $19^{\text {th }}$ century British attitudes toward the Arab slave trade in East Africa were ambivalent. ${ }^{14}$ In 1893 due, in part, to the ineffectual control of the IBEAC, the British government sent Sir Gerald Portal, the consul-general for Zanzibar, to Uganda as a prelude to formal British control of the area. ${ }^{15}$ During his journey Portal employed slaves as porters. The IBEAC regularly used Zanzibari porters, most of whom were slaves, on their caravan routes, also. ${ }^{16}$ In East Africa, porters were frequently employed for expeditions and caravans. On many occasions, the porters were slaves that hired out their labor for the duration of the caravan with the stipulation that half of their wages would go to their masters. The slave was usually payed half of his wages at the start of the journey, which went directly to the master. Whether slave or free, the life of a porter was extremely harsh as many porters had to carry loads in excess of eighty pounds in addition to

${ }^{12}$ Great Britain, Parliamentary Debates, Commons, 3dser., Vol.344 (1890), col. 939.

${ }^{13}$ Ibid.

${ }^{14}$ Nwulia, Britain and Slavery in East Africa, 41.

${ }^{15}$ Portal's mission resulted in an Agreement between the British and the lame duck Kabaka Mwanga of the kingdom of Buganda. As a result, the British declared a protectorate over Buganda in July 1894.

${ }^{16}$ Beachey, The Slave Trade of Eastern Africa, 221. 
their own personal food and water. In H. M. Stanley's relief expedition for Emin Pasha, the MP, and member of the BFASS, Joseph Pease stated, for example, that 450 of Stanley's porters perished during the journey. ${ }^{17}$

The BFASS criticized British officials for using slaves. On 6 May 1890 Pease again questioned the Under Secretary of State for Foreign Affairs, Sir John Ferguson, concerning the use of slave porters by H.M. Stanley's expedition to relieve Emin Pasha. ${ }^{18}$ According to Pease, slave porters hired by Stanley's expedition were immediately returned to their owners upon completion of the expedition. The porters wages were then garnished by their owners. The reply from the Foreign Office, on this occasion, was that the slaves "voluntarily went back." 19 The BFASS followed up with a formal letter to Salisbury bringing attention to the use of slave porters by the Stanley expedition and by Harry Johnston, the British Commissioner for the Nyasaland Protectorate. ${ }^{20}$ The BFASS criticized British official for using slave porters on the grounds that it led to an augmentation of slavery and the slave trade, but they also criticized it for another reason. The hypocrisy of British officials using slave porters according to the BFASS might "create confusion in the minds of the great Slave-trading chiefs." $"$ The matter was not decided by these protests, however.

\footnotetext{
${ }^{17}$ Joseph Pease, How we Countenance Slavery (London: British and Foreign AntiSlavery Society, 1895), 5

${ }^{18}$ Great Britain, Parliamentary Debates, Commons, 3d ser., Vol.44 (1890), col. 255. H.M. Stanley, the famous explorer had been commissioned by the Anglo-Belgian Katanga Company to provide relief to Emin Pasha, the European Governor of Equatoria province of Egypt, who had been cutoff due to the Mahdist revolt in Sudan.

${ }^{19}$ Ibid., 256.

${ }^{20}$ Anti-Slavery Reporter, July and August 1891, 160.

${ }^{21}$ Ibid.
} 
On 1 June, Pease questioned the Under Secretary of State for Foreign Affairs again about Harry Johnston's use of slave porters. This time the Under Secretary replied that :

There is no regulation against the engagement of Slaves as porters, provided that contracts are made direct with them, nor would it seem desirable to deprive Slaves of the advantage of free labour under European leaders. ${ }^{22}$

The reply from the BFASS was predictable. It pointed out that even though slaves were introduced to the advantages of free labor, the transaction still amounted to recognition of slavery. ${ }^{23}$ In addition, the Society made an even more salient point. British officials were forbidden from using slaves by governmental precedent. The Society pointed out that on 8 May 1841 Viscount Palmerston of the Foreign Office issued a circular to British officials in slave holding countries stating that it would be "unfitting" of any officer of the British Crown to hold interests in slave property. ${ }^{24}$

The BFASS was more forgiving of the IBEAC use of slaves porters, though. As Joseph Alfred Pease mentioned, "I wish to say that I believe that Company have pursued the best policy with regard to slavery that an enterprising company could pursue in Africa." ${ }^{25}$ The reason for this good feeling towards the IBEAC was perhaps revealed by Horace Waller in a paper entitled "White Ivory and Black." Referring to the IBEAC and slavery, Waller stated that, " . . the East Africa chartered Company is doing everything in its power to pit freedom against slavery. Sir Fowell Buxton's connection with its efforts is alone a guarantee in this direction." 26 The BFASS

${ }^{22}$ Anti-Slavery Reporter, July and August 1891, 168.

${ }^{23}$ Ibid., 161.

${ }^{24}$ Ibid.

${ }^{25}$ Ibid., May and June, 1890, 134.

${ }^{26} \mathrm{He}$ sat on the Board of Directors. Ibid., 87. 
also criticized missionary groups for using slave labor. An article entitled "Do British

Missionaries Encourage Slavery in Madagascar" criticized missionaries for the Church of England in Madagascar for using slave labor. ${ }^{27}$

The difficulties of transport reflected in the use of slave porters also brought to light the contradictory manifestations of free versus slave labor. The BFASS had been preaching since 1840 that free labor was more efficient than slave labor when put in competition. As stated in the Anti-Slavery Reporter, "Free labour and Slave labour have never worked well together, and the experience of those countries which employed slave labour has been that after Slavery was abolished production increased." ${ }^{28}$ Slave porters contradicted this axiom. To combat the use of slave porters and the slave trade, generally, in the interior of East Africa, the BFASS threw its support behind the construction of the Uganda Railway from Mombasa on the east coast of Africa to the interior of the East Africa Protectorate. Significantly, Joseph Pease argued, that the “. . .nation which first makes the railway will receive the commercial and political supremacy in Equatorial Africa." 29

BFASS support of the Uganda railway was in line with their support of British colonization of Uganda. In 1893 the Foreign Office sent Sir Gerald Portal to Buganda to report on the political situation in that kingdom in light of IBEAC's meddling in its political affairs. When he returned, Portal presented his report to parliament in March 1894. His report became the basis for the assumption of a protectorate over Uganda. Portal's report also pushed the issue of slavery in East Africa to the forefront by way of Uganda. In a despatch to the Earl of Rosebery, Foreign

\footnotetext{
${ }^{27}$ Anti-Slavery Reporter, February 1883, 35. This article drew a lot of fire from church and missionary organizations.

${ }^{28}$ Ibid., January and May, 1895, 4-5.

${ }^{29}$ Pease, How We Countenance Slavery, 7.
} 
Secretary, on 1 November 1893, Portal called for the transfer of Buganda to the sphere of influence of Zanzibar as one of the ways of checking slave raiding and slave trading that was going on in the area. ${ }^{30}$ Many humanitarian organizations, like the BFASS, called for Britain to assume a protectorate over Uganda as a way of stamping out slave trading and raiding. The BFASS felt that colonization of Uganda would stop the slave trade in the interior of East Africa. As the MP Joseph Pease stated in a House of Commons supply debate, .. . if Great Britain declined to remain in Uganda a great opportunity would be afforded to the Arab slave raiders to pursue their horrible operations unrestrained in the center of Africa and to make Slave-raids in the district between Uganda and the Coast. ${ }^{31}$

On 1 June 1894, in both houses of parliament, a debate on slavery erupted around the issue of British control of Uganda. The basic question was should Britain assume a protectorate over Uganda or leave "the country to fall back into barbarism." ${ }^{, 32}$ Joseph Pease, speaking on behalf of the BFASS, advocated British control over Uganda as a way of retarding the East African slave trade. ${ }^{33}$ Ironically, despite his calls for the assumption of British control in Uganda, Pease did not favor immediate abolition of slavery in that territory. ${ }^{34}$ In contrast to Zanzibar, Pease maintained that domestic slavery was more prevalent in Uganda. According to Pease, domestic slavery required only the abolition of legal status as opposed to outright emancipation of slaves. ${ }^{35}$ Pease

${ }^{30}$ Sir Gerald Portal to Earl of Rosebery, 1 November 1893. Printed in Anti-Slavery Reporter, March and April, 1894, 75.

${ }^{31}$ Great Britain, Parliamentary Debates, Commons, $4{ }^{\text {th }}$ ser., vol.25 (1894), col. 234.

${ }^{32}$ Ibid.

${ }^{33}$ Ibid.

${ }^{34}$ Ibid.

${ }^{35}$ Ibid., 235. 
argued that outright emancipation would lead to economic hardship due to the sudden withdrawal of labor. Abolition of the legal status of slavery, however, would be a much more subtle and gradual liberation of labor. Pease's stance at this point would contrast with his later position on slavery in Zanzibar. The multifaceted humanitarian initiative against slavery in Uganda was a microcosm of the contradictions of humanitarian protests against bonded labor that would later be apparent in the forced labor problems of the colonial period in Kenya.

In early 1895 , due to lagging economic fortunes and mismanagement, the British government bought out the charter of the IBEAC for 250,000 pounds and also bought out the Sultan of Zanzibar's interests on the ten mile strip of the East African coast. The East Africa Protectorate was born. With the declaration of the East Africa Protectorate (EAP) on 1 July 1895 came the requisite question of slavery on the coast of Kenya. ${ }^{36}$ Slavery still existed in Zanzibar and on the ten-mile strip of coastal Kenya. Under Sir Arthur Hardinge, the first Commissioner of the EAP and Zanzibar, the administration employed a gradualist approach to ending slavery. ${ }^{37}$

\section{Slavery in the EAP and British Policy}

With the assumption of the East Africa Protectorate (EAP) in 1895, the British government readily accepted the reality of slavery in the EAP. Despite the 1890 decree that ended the exchange and sale of slaves, slaves were openly bought and sold. An agreement of 1889 which

${ }^{36}$ The creation of the East Africa Protectorate on 1 July 1895 over the area between Mombasa and the Rift Valley was a result of an agreement between Germany and Great Britain over spheres of influence in East Africa.

${ }^{37}$ Beachey, The Slave Trade of Eastern Africa, 242-243; Suzanne Miers and Martin Klein, Eds. Slavery and Colonial Rule in Africa , 20. Sir Arthur Hardinge, due to his prior colonial experience in the Middle East, believed that Islamic slavery was a milder variant of bonded labor. In addition, he felt that the hurried eclipse of slavery on the east coast of Kenya would lead to social disruption.

$$
\text { Page -88- }
$$


set free slave children born after 1 January 1890 was also flouted. The British government's policy regarding slavery in the EAP would follow the precedent set by the IBEAC and espouse a slow and gradual abrogation of slavery. This meandering approach to ending slavery in the EAP elicited a wave of humanitarian criticism that similarly followed tradition.

The first commissioner of the EAP and Zanzibar, Sir Arthur Hardinge (1895-1900), advocated a policy of gradual abolition of slavery. Hardinge based his position upon several factors. First of all, there was a social factor. Hardinge came from a patrician background and had served in earlier diplomatic posts in the Middle East and Turkey.$^{38}$ His background in Southwest Asia imbued him with the idea that Asian or Arab slavery was a mild variant of bonded labor. For Hardinge, then, slavery in East Africa was not as cruel as slavery in the West because it had not developed according to the dictates of unbridled capitalism. ${ }^{39}$ According to Hardinge, slaves in the clove plantations were not worked that hard, and domestic slaves, since they were considered part of the family lineage, were treated better. As Hardinge stated in an 1899 letter to Lord Salisbury, the Secretary of State for Foreign Affairs, "In many respects the state of the African slave is better or rather easier to him than the state in which many free born

\section{${ }^{38}$ Beachey, The Slave Trade of East Africa, 242.}

${ }^{39}$ Ibid., 243. On the impact of industrial capitalism upon the development of slavery in the West see also: Robert Brent Toplin, Freedom and Prejudice: The Legacy of Slavery in the United States and Brazil. (Westport and London: Greenwood Press, 1981); Stanley Elkins, Slavery: a Problem in American_Institutional and Intellectual Life, (Chicago and London: The University of Chicago Press, 1968); Herbert Klein, Slavery in the Americas: A Comparative Study of Virginia and Cuba (Chicago: The University of Chicago Press, 1967); C. N. Degler, "Slavery in Brazil and the United States: A Comparison," American Historical Review LXXV(1970): 1004-28; Eugene Genovese, "The Treatment of Slaves in Different Countries: Problems in the Application of the Comparative Method." in Laura Foner and Eugene Genovese, Slavery in the New World (Englewood Cliffs, Prentice Hall, 1969), 203-5.

$$
\text { Page -89- }
$$


natives find themselves." ${ }^{40}$

For Hardinge, then, immediate abolition would be troublesome for the slave holding society in East Africa. If immediately released, most of the slaves would be disinclined to work, due to their natural sloth, leading to labor problems. Immediate abolition would also leave many slaves destitute. Without a paternal figure to care for them, many slaves would fall into dire poverty and vice. Hardinge's views on East African slavery represented the evolving official position and resulted in a gradual pace of abolition.

\section{Humanitarian Outcry Over Slavery in the EAP}

The gradualist approach to ending slavery in the EAP evoked protest from many humanitarian groups like the BFASS and resulted in a flood of memorials to the Foreign Office. The FO responded, in kind, apropos Sir Arthur Hardinge. Hardinge responded to the criticism of his policy through a brilliant exposition of pro slavery arguments.

Due to the Society's contacts with sympathizers like Sir John Kirk, the former consul to Zanzibar (1866-1873), the BFASS was aware of the continuing machination of slavery and the slave trade in Zanzibar and its dominions in direct violation of the various treaties that had been passed to limit the slave trade. ${ }^{41}$ Even before the EAP came under British influence in 1895 the Society had been petitioning the British government to end the legal status of slavery since

${ }^{40}$ Hardinge to Salisbury, February 17, 1899, "Slavery in Africa Printed Papers," Box G 118/A, Papers of the British and Foreign Anti-Slavery Society and Aborigines Protection Society, Rhodes House Library, Oxford.

${ }^{41}$ Kirk to Fowell Buxton, 18 April 1873, Box G/7, Papers of the British and Foreign AntiSlavery Society and Aborigines Protection Society, Rhodes House Library, Oxford.

$$
\text { Page -90- }
$$


$1886 .{ }^{42}$ In 1888 Sir Euan Smith, a British Agent on Zanzibar, wrote to the Society admitting that

I may tell you confidentially that in my opinion, the time has arrived when a great push should be made by the English people to bring about the abolition of slavery within the islands of Zanzibar and Pemba. . . I do, indeed, threfore trust that your Society will leave no stone unturned in having this question earnestly and vigorously impressed upon the English public and on H. M.'s government. ${ }^{43}$

In 1893 the BFASS sent a memorial to the Earl of Rosebery, the Secretary of State for Foreign Affairs. ${ }^{44}$ The memorial questioned Rosebery about the responsibilities Britain was prepared to take regarding slave trading from the mainland of East Africa to Zanzibar, in light of the recent declared protectorate over Zanzibar. ${ }^{45}$ The BFASS indicated that Great Britain's association with slavery in the EAP was a stigma, considering her past actions against slavery in India, the Gold Coast and Cyprus. Consequently, the Society called upon Rosebery to end the legal status of slavery in Zanzibar.

In the memorial, the Society further pointed out that in 1884 Sir John Kirk had written a report to the Earl of Granville calling for the abolition of the legal status of slavery. The BFASS also alluded to a previous memorial to the Marquis of Salisbury, where he had promised the Society that he would seize every opportunity to persuade the Sultan of Zanzibar to adopt a policy "in the interests of humanity and civilization." 46

${ }^{42}$ Anti-Slavery Reporter, June and August, 1895, 119. The BFASS had petitioned the Foreign Office about ending the legal status of slavery in 1888 and again in March 1889.

${ }^{43}$ Euan Smith to Secretary of British and Foreign Anti Slavery Society, 17 December 1888, Box G3, BFA/SAPS, Rhodes House Library, Oxford.

${ }^{44}$ Anti Slavery Reporter, June and August, 1895, 118-119.

${ }^{45}$ Ibid.

${ }^{46}$ Ibid. 
Rosebery responded to the Society in August 1893 indicating that the matter would be examined further. He also instructed Rennel Rodd, Consul-General in Zanzibar (1892-1894), to examine the Society's position and furnish his opinion. ${ }^{47}$ In response, Rodd produced a report on slavery in Zanzibar that echoed many of the pro slavery themes that Hardinge later advanced.

In his report, Rodd advanced three arguments that dealt with the geopolitics, practicality and benefits of abolition of slavery in Zanzibar. In terms of geopolitics, Rodd asserted that an abrupt end to slavery in the British sphere of influence would lead to an imbalance of power. Disaffected Arabs would simply migrate to German East Africa depopulating the Sultan's territory. ${ }^{48}$ Rodd called for a gradual abrogation of slavery. Besides the geopolitical factors, he also argued that an abrupt cessation of slavery would spell economic disaster for clove plantations, that were heavily dependent upon slave labor. This would in turn cause economic ruin for the Arab planters. Rodd also added a social factor. He questioned the supposed benefits of freedom that an abrupt abrogation of slavery would bestow upon African slaves. According to Rodd, Arab slavery on the clove plantations was a mild form of slavery. ${ }^{49}$ Many rural slaves were satisfied with their condition, and a quick end to slavery would leave many of them in poverty.

In response to Rodd's report, the BFASS published an earlier memorandum on slavery in Zanzibar by the Consul-General to Zanzibar Colonel C. S. Smith in the Anti-Slavery

\footnotetext{
${ }^{47}$ Rosebury to Rodd, 14 August 1894, printed in Anti-Slavery Reporter, June and August, 1895.

${ }^{48}$ Nwulia, Britain and Slavery, 179.

${ }^{49}$ Ibid., 180.
} 
Reporter. ${ }^{50}$ Smith was a lone dissenter against gradual abolition of slavery among the British officials in Zanzibar and his report contradicted many of the points made by Rodd. ${ }^{51}$

In his report Smith pointed out the embarrassingly obvious fact. Most of the slaves in Zanzibar were held illegally anyway. This was because many slaves in Zanzibar had been transported to the island after the 1873 decree that supposedly ended the slave trade by sea. To this group of illegal immigrants, Smith added the number of slaves born of slave parents after 1890 and slaves held by persons who had been freed by British authority. Smith calculated that only 5 to 10 percent of slaves were legal. The rest were entitled to freedom.

As a solution, Smith called for the immediate abolition of the legal status of slavery in Zanzibar and its island domains according to the abolition model used in India in 1843. Smith argued that this method of "permissive freedom" would lead to less political instability. Of note, Smith did not call for similar measures on the mainland. He deemed it "very doubtful wisdom" to introduce such measures on the mainland until British influence was more fully entrenched. ${ }^{52}$ Smith called for compensation to the owners who maintained slaves legally as a politically astute move that would negate later political problems. ${ }^{53}$

Smith summed up his report by emphasizing two factors: free labor and the willingness of the Africans to work. According to the Consul-General, his experience had shown that most "natives" both free and slave were willing to work and would seek wage employment after being

${ }^{50}$ Anti-Slavery Reporter, June and August 1895, 121-126.

${ }^{51}$ Smith originally wrote the memorandum in January 1894.

${ }^{52}$ Anti-Slavery Reporter, June and August, 1895, 123. This was a tactical compromise which exposed the political intent in British abolition. Slavery on the mainland coast of the Sultan's domains would be a problem for the EAP.

${ }^{53}$ When the issue of compensation came up after the abrogation of the legal status of slavery in Zanzibar in 1897 humanitarian organizations were completely against it. 
manumitted. Quoting from Sir John Kirk, Smith reemphasized that free labor and slavery could never mix. He closed by stating that "It will be seen, therefore, that abolition of the status of slavery would bring the benefit of a natural immigration of free labour from the coast. .."54

During the time that Rodd's report was delivered, there was a change in prime ministers in Britain as Lord Rosebury came to power replacing William E. Gladstone. The new Liberal Foreign Secretary, Lord Kimberley, received the report and asked the Commissioner of the EAP and Zanzibar, Hardinge, in May of 1894 to "recommend any further measures which may seem to you feasible for facilitating the total abolition of slavery without injustice to the Mahommedan owners." $" 55$ Kimberley followed up with another letter in November 1894 to Hardinge that asked him to consider whether some fresh steps ought to be taken in regards to the speedy extinction of slavery in the Zanzibar. Kimberley, however, made it clear, though that:

the general policy followed by this country has been to use all legitimate means . . . for complete and prompt suppression of Slavery and the Slave-trade, but in countries such as Zanzibar, where the institution of domestic Slavery has grown up with and forms part of the social life of the inhabitants, to resort only to such measures for its abolition as being gradual in their operation, may effect the change without unnecessary disturbance. ${ }^{56}$

Hardinge responded to Lord Kimberley in two despatches on 26 February and 13 March 1895; however, during the interim the issue of slavery came up in parliament.

In the House of Commons, Joseph Pease, parliamentary spokesman for the BFASS, carried on the attack. On 7 February 1895, Pease raised the issue of slavery in Zanzibar. Pease queried the Under Secretary of State for Foreign Affairs, Edward Grey, about the steps the government

${ }^{54}$ Anti-Slavery Reporter, June August, 1895, 125.

${ }^{55}$ Nwulia, Britain and Slavery, 181.

${ }^{56}$ Earl of Kimberley to Hardinge, 27 November 1894 printed in Anti-Slavery Reporter, June and August, 1895. 
had taken to abolish slavery in Zanzibar and Pemba. ${ }^{57}$ Grey, alluding to the Kimberley's despatch to Hardinge, replied the FO was still waiting for further information. ${ }^{58}$

During the interim, the BFASS enlisted the aid of several religious organizations to take action against slavery and the slave trade in Zanzibar. ${ }^{59}$ On 1 March, Pease presented a petition from the Society of Friends, the Congressional Union and fifteen other organizations calling for the abolition of slavery in Zanzibar. The petition emphasized that the stigma of slavery in Zanzibar sullied Great Britain's anti slavery record. It stated that "since it has been the glory and the boast of Great Britain that slavery cannot exist in British territory" slavery in Zanzibar must be abolished. ${ }^{60}$ Pease raised the petition in hopes that the House would pass a motion demanding the abolition of slavery in British protected territories. Although he failed on this account, he was treated to a rousing cheer from his colleagues. ${ }^{61}$

On 8 March 1895 Pease raised the issue of the abolition of slavery in Zanzibar in the House of Commons. On that date, the House voted on a supplementary measure to decide whether five hundred pounds should be allocated for extra services in connection with the suppression of the East African slave trade. As a symbolic protest, Pease moved for a reduction in the amount by one hundred pounds. He argued that the amount of money being voted upon was so paltry it

${ }^{57}$ Great Britain, Parliamentary Debates, Commons, $4^{\text {th }}$ ser., vol. 40 (1895), col. 196. Pease would also later become Vice-president of the society.

${ }^{58}$ Ibid.

${ }^{59}$ The main group was the Society of Friends, but the BFASS also enlisted aid from the Baptists and the Wesleyans.

${ }^{60}$ Anti-Slavery Reporter, January and May 1895, 19.

${ }^{61}$ Ibid., 18. 
would not accomplish its task, the suppression of the slave trade. ${ }^{62}$

Informed by Sir John Kirk, Pease stated that the amount of slaves imported into Zanzibar and Pemba had actually been increasing for the last ten years. He argued that the British government was not even fully aware of the extent of slavery in Zanzibar and Pemba and consequently could not hope to take adequate measures through such a niggardly sum of money. Pease, instead, proposed that the only effective means of suppressing the East African slave trade was to end the demand for slaves on the islands by emancipating them or abolishing the legal status of slavery. ${ }^{63}$

Along these lines, Pease also called for the building of the Uganda railway as a means of extirpating the demand for slaves. Pease, along with the BFASS, felt that a railway would decrease the need for porters. This, in turn, would take away one of the "demands" for slave labor since many porters were also slaves.

The Under-Secretary replied simply that the FO was waiting for more information. Other Members of Parliament raised pertinent questions which assailed the British policy of slavery in the EAP. Charles Dilke erroneously stated that if the protectorate was under the control of the CO slavery would be put to an end quickly. ${ }^{64}$ Joseph Chamberlain followed Pease's lead and called for the abolition of slavery "at the fountainhead." However, he also pointed out the ambivalence of slavery under the British flag in Zanzibar. ${ }^{65}$

As stated earlier, Hardinge replied to the humanitarian criticism in two despatches to

${ }^{62}$ Great Britain, Parliamentary Debates, Commons, $4^{\text {th }}$ Ser., vol. 31 (1895), col. 664.

${ }^{63}$ Ibid., 672.

${ }^{64}$ Ibid., 667.

${ }^{65}$ Ibid., 674-75. 
Kimberly that advanced Rodd's earlier pro slavery arguments. Hardinge advised against quick abolition of slavery based upon economic and social factors. In terms of the social aspects, Hardinge felt that a quick abolition of slavery would leave many Africans without benefactors which would encourage idleness and other vices. ${ }^{66}$ Along these lines, Hardinge argued that many concubines would be forced into prostitution if forced into the market place. In a tactical move, Hardinge hinted that Arab slavery was more mild due to the palliative effects of Islam. ${ }^{67}$

Hardinge's economic argument reemphasized Rodd's theme that abrupt abolition of slavery would lead to economic impoverishment of the planter class and their Indian creditors. He also added that application of India Act in Zanzibar would lead to additional costs. Hardinge skillfully deflected the call for immediate abolition of the legal status of slavery, however, the controversy would not die peacefully. The FO's pro slavery arguments aroused the consternation of humanitarians. The publication of a report on slavery and the slave trade in Zanzibar by BFASS representative Donald Mackenzie contradicted several of the FO's assumptions and further raised the ire of the humanitarian lobby.

The BFASS had commissioned Donald Mackenzie to serve as a Special Commissioner to enquire into the state of slavery and the slave trade in Zanzibar. Mackenzie arrived in Zanzibar on 2 March and proceeded to visit Pemba, Dar es Salaam, Mombasa and Lamu. His stay lasted one month. Following his visit, Mackenzie traveled to Aden where he wrote up his report. The forty page report was presented to the Central Committee of the BFASS and published in May $1895 .^{68}$ The report was published by the BFASS and sent to over one hundred organs of the

${ }^{66}$ Nwulia, Britain and Slavery, 182.

${ }^{67}$ Anti-Slavery Reporter, June and August 1895, 128.

${ }^{68}$ Donald Mackenzie to Charles Allen, May 1895, "Report on Slavery and the Slave Trade in Zanzibar, Pemba and the Mainland," Box G3, BFASS/APS, Rhodes House Library, Oxford. 
press. Mackenzie's descriptions of slavery in Zanzibar cast doubt upon several official depictions of slavery in Zanzibar purported by the FO and called for the abolition of slavery in Zanzibar.

In his report Mackenzie cast a dubious light on the official depiction of Arab slavery as mild. He traveled through Zanzibar and Pemba and observed slavery on the plantations firsthand. At Chaki Chaki on Pemba, Mackenzie came upon a prison that housed both male and female runaway slaves. He surmised that since the slaves were all in chains perhaps slavery in Zanzibar was not so mild. As he stated:

All the others I found were wearing those ponderous chains and fetters because they had attempted to run away from their cruel masters and gain their freedom--a very eloquent commentary on the happiness of the Slaves. ${ }^{69}$

In Pemba Mackenzie met a widow plantation owner who had set all of her husbands slaves free upon his death. She informed him that all of the freed slaves were now prospering on their own. For Mackenzie, this indicated that "the blacks are not so lazy as some people try to make out."

Mackenzie noted in his report that the slave population in Zanzibar and Pemba did not reproduce itself. As a result, slaves were still being imported into the islands at prodigious rates. He estimated that 6,000 slaves per year were imported into Zanzibar and Pemba from the mainland of East Africa. In contradiction to the Report of the Select Committee on the East African Slave Trade of 1871, Mackenzie also estimated that 11,000 slaves were imported from mainland East Africa to Arabia. ${ }^{71}$

\footnotetext{
${ }^{69}$ Mackenzie's report printed in Anti-Slavery Reporter, June and August 1895, 73.

${ }^{70}$ Ibid., 79.

${ }^{71}$ Ibid., 90-91. The Select Committee estimated that upwards of 20,000 slave were imported into Arabia from East Africa. 
In summation, Mackenzie called for the immediate abolition of slavery. Harkening back to Adam Smith's free labor argument, Mackenzie based his assertion upon the benefits of free labor. He argued that, if freed, slaves would easily transition into free laborers due to the increased wants occasioned by a free market. Mackenzie stated:

If the slaves were free they would receive their pay in full, work more willingly and better for their employers, and, the blacks being vain and fond of dress, their freedom would, in my opinion improve the trade in manufactured goods. ${ }^{72}$

Positive feedback of the report further pushed the issue of slavery in the EAP to the forefront. The Liverpool Daily Post on 14 August 1895 compared passages of Mackenzie's report to famous American abolitionist tract Uncle Tom's Cabin. ${ }^{73}$ The Church Missionary Society Bishop for East Africa, Alfred Tucker, also wrote in support of abolition. ${ }^{74}$ In a letter to The Times of London on 2 July 1895 Tucker supported Mackenzie's call for abolition believing that it would lead to increased production as opposed to economic dislocation for the Arab and slave population. ${ }^{75}$ And, in a move that would characterize Tucker's controversial support of African rights, he also advocated compensation for the owners. As we will see later, most humanitarian organizations, like the BFASS, did not support compensation for the Arab masters in East Africa. $^{76}$

${ }^{72}$ Anti-Slavery Reporter, June and August 1895, 94.

${ }^{73}$ Ibid., 101.

${ }^{74}$ Tucker was an ardent critic of the British policy regarding Africans in East Africa. He was also a corresponding member of the BFASS. Though he spent most of his time in Uganda, he was also a defender of the rights of slaves and freed slaves on the coast. He would also be prominent in labor controversies in the early twentieth century in the EAP.

${ }^{75}$ Printed in Anti-Slavery Reporter, June and August, 1895, 104.

76، Address From the London Anti-Slavery Committee," 4 April 1899, Box G/113, BFASS/APS, Rhodes House Library, Oxford. 
Following Mackenzie's report, the BFASS sent a long memorial to the Marquis of Salisbury, the Secretary of State for Foreign Affairs, on 2 August $1895 .^{77}$ In the memorial the Society reiterated its previous attempts to persuade the FO to abolition of slavery in Zanzibar. In light of Mackenzie's report, the memorial, again, called for the immediate abolition of slavery in Zanzibar.

In the House of Commons, on 16 August 1895 , the MP's Thomas Bayley and Joseph Pease raised the issue of abolition in Zanzibar. ${ }^{78}$ Pease asked the Under Secretary for Foreign Affairs, George Curzon, what steps were being taken to abolish slavery in Zanzibar and the legal status of slavery in the rest of the British African protectorates. Bayley, on the other hand, asked Curzon what measures were being taken to abolish slavery in Zanzibar in light of Mackenzie's report. Curzon deftly replied that the FO was familiar with Mackenzie's report and that it would be impractical to end slavery in all British African protectorates. ${ }^{79}$ He added vaguely, however, that measures were being taken to end slave raiding and ameliorate abuses under slavery.

On 21 August the abolition of slavery in Zanzibar came up again in the Committee of Supply of the House of Commons. The debate arose on a vote for 40,000 pounds to complete the costs necessary to defray the salaries and expenses for the Foreign Office in the EAP. A motion was debated whether to reduce the amount by 1,000 pounds due to the FO's lack of effectiveness in dealing with slavery in Zanzibar. Sir Charles Dilke led the attack when he asked the Under-

\footnotetext{
${ }^{77}$ Anti-Slavery Reporter, June and August, 1895, 105-108. The Liberal government under the Earl of Rosebery had given way to the Conservative government of the Marquis of Salisbury, who was both Foreign Secretary and Prime Minister, in June 1895.

${ }^{78}$ Great Britain, Parliamentary Debates, Commons, $4{ }^{\text {th }}$ Ser., vol. 36 (1895), col. $152-53$.

${ }^{79}$ Ibid., 497.
} 
Secretary of State, Curzon, why the FO had done nothing concerning slavery in Zanzibar. ${ }^{80}$

Curzon reiterated his response from the $16^{\text {th }}$ of August that the FO was still in consultation with Hardinge and that they were doing something against slave raiding. In addition, he called for patience since the present Conservative government had only been in power three weeks. ${ }^{81}$

Despite the calls for patience, on 14 October 1895, the BFASS covened a public meeting, ostensibly to fete Mackenzie on his return from Zanzibar, but, also, to consider the question of slavery in Zanzibar and Pemba under British rule. The meeting was attended by many notable humanitarians including, H. R. Fox-Bourne of the Aborigines Protection Society and Horace Waller and was chaired by the, then, president of the BFASS, the MP Arthur Pease.

Pease opened the session with the scandalous assertion that upwards of 500,000 Africans were sacrificed to the East African slave trade every year. ${ }^{82}$ This was followed by a long speech form Donald Mackenzie criticizing British anti-slavery policy in East Africa, pointing out that the anti-slavery treaties of 1873 and 1890 were in essence dead letters. Mackenzie also undermined the pro slavery arguments of the FO by stating that free labor would work if the African slaves were emancipated. Mackenzie pointed out that there were already Arab free laborers in Zanzibar. The meeting ended with the passage of resolutions calling for ending the legal status of slavery on Zanzibar and Pemba. ${ }^{83}$

${ }^{80}$ Ibid., 498.

${ }^{81}$ By way of footnote, in this particular debate Henry Morton Stanley, in a maiden speech as MP for Lambeth North, spoke out against the building of the Uganda railway by blasting the BFASS and other "fanatics" who would drive the government into rash action as he put it. The BFASS supported the railway as a means of suppressing the need for porters and hence slave labor. Ibid., 505.

${ }^{82}$ Anti-Slavery Reporter, September and November 1895, 149.

${ }^{83}$ Ibid., 161. 
On 27 March 1896 Pease brought up the issue of slavery in Zanzibar during a civil service vote. On this occasion, he called for the reduction of the allotment by two hundred pounds on the grounds that the British government was not pursuing a satisfactory anti-slavery policy in East Africa. ${ }^{84}$ Curzon, relying upon Hardinge, replied that ending the East African slavery abruptly would flout a religious war. ${ }^{85}$

On 14 November 1896, a deputation from the Society of Friends and the BFASS called upon the Under Secretary of State for Foreign Affairs, Curzon, to urge the government to abolish slavery immediately on Zanzibar and Pemba. ${ }^{86}$ At this point, Curzon put off the deputation by stating that the FO was waiting for more information from Hardinge, the FO's Consul General for Zanzibar. Curzon also re-emphasized the common pro-slavery arguments of the Foreign Office. According to the Under Secretary, slavery was generally recognized in Islamic societies, Zanzibar being no exception. In addition, Curzion was concerned about the effect of releasing "a large exodus of slaves from the plantations." 87 Besides the problem of vagrancy, immediate abolition would also lead to impoverishment for the Arab slave owners.

Undeterred, the BFASS followed with more memorials. On December 1896 a letter to the Under Secretary of State for Foreign Affairs implored the British government to end slavery immediately and stated:

That any measure short of the immediate abolition of the legal

${ }^{84}$ Great Britain, Parliamentary Debates, Commons, $4^{\text {th }}$ ser. Vol. 39 (1896), col. 311.

${ }^{85}$ Ibid., 315.

${ }^{86}$ British and Foreign Anti-Slavery Society, Slavery in British Protectorates: Memorials of the British and Foreign Anti-Slavery Society and other Documents Connected with Slavery and the Slave Trade in the Sultanate of Zanzibar (London: British and Foreign Anti-Slavery Society, 1897), 14.

\footnotetext{
${ }^{87}$ Ibid., 17.
} 
status of slavery in the entire Sultanate of Zanzibar, will meet with the strenuous opposition of the British and Foreign AntiSlavery Society. ${ }^{88}$

Eventually, on 10 February 1897 the Marquess of Salisbury wrote Hardinge with instructions concerning the negation of the legal status of slavery on Zanzibar and Pemba. ${ }^{89}$ Hardinge was to make recommendations to the Sultan of Zanzibar that would facilitate the abrogation of the legal status of slavery. Despite the abolitionist tone, Salisbury's instructions were communicated with certain stipulations that would shadow the eventual decree.

For example, Salisbury indicated to Hardinge that the decree should not tamper with Arab "family rights." Consequently, the abrogation of the legal status would not apply to concubines. Salisbury was also concerned about the attenuation of the labor market caused by the release of so many slaves. Specifically, he was worried that the newly released slaves would not work. Although he disavowed any form of apprenticeship, he did recommend that Hardinge increase the numbers of police as a deterrence against vagrancy and to, also, institute a hut and poll tax. Salisbury also suggested the adoption of measures that would stop runaway slaves from leaving the islands, so that their labor power would still be available for disposal. Regarding compensation for slave holders, Salisbury instructed Hardinge that compensation would be allowed to slave holders who could prove legal ownership based upon the 1890 anti slavery decree forbidding the exchange and sale of slaves.

Salisbury's instructions to Hardinge resulted in a proclamation, on 6 April 1897, by the Sultan of Zanzibar, Hamoud bin Mahomed bin Said. The decree ended the legal status of

${ }^{88}$ British and Foreign Anti-Slavery Society Memorial 18 December 1896.

${ }^{89}$ Great Britain, Instructions to Mr. Hardinge Respecting the Abolition of the Legal status of Slavery in the Islands of Zanzibar and Pemba, Cmd. 8394, (April 1897), 372.

Page -103- 
slavery. This meant that courts of law under the Sultan's domains would not recognize, by law, alleged rights over body, service or property of any person over another based upon slavery. In practice this meant the non recognition of the legal status of slavery while leaving the actual institution intact. Slaves, who wished to do so, could leave their masters but were not informed of their rights.

The loss of legal slave status did not apply to concubines. Article V of the decree defined concubine slaves as part of the harem in the same sense as wives. They could not redeem their freedom unless they proved cruelty on the part of the master. In addition, the non recognition of the legal status of slavery was also not applicable to the mainland possessions of the Sultan's domains. Slaves could redeem their freedom, but under Article IV there were stipulations attached to freedom. Before being granted freedom, slaves had to prove they had a place to work. Furthermore, after emancipation they were liable for the hut and poll tax.

This method of abolition followed the pattern which had been successfully applied in India in 1843. ${ }^{90}$ In India the abolition law simply denied legal status to domestic servitude. Even though it was erroneous to suggest that, as the BFASS stated, the act put "upwards of a million persons . . .upon the same footing as free men," slaves could now not be claimed in a court of legal jurisdiction..$^{91}$

Foreign Office reports as to the efficacy of the act reflected the true nature of its intent, however. According to Hardinge, 3,757 slaves were freed as a result of the proclamation in

${ }^{90}$ Mr. H. W. De Sausmarez to Foreign Office, 25 December 1895, CAB 37/40/66.; Suzanne Miers, "Slavery and the Slave Trade as International Issues, 1890-1939" Slavery and Abolition 19 (2) (August 1998): 19.

${ }^{91}$ Anti-Slavery Reporter, September and October, 1890, 247. 
1899. ${ }^{92}$ The official reason for the slow pace of emancipation was attributed to a lack of desire for freedom on the part of the slaves. The Slavery Commissioner for Zanzibar, Sir Lloyd Mathews, stated, in reference to the slaves, that "they all know that they can be free whenever they choose to be so, but the greater number of them fail to see that freedom would bring them any particular advantage."93 Mathews added that slavery in Zanzibar was mild and the quality of life for the slaves was better than free born Africans. Freedom would not bestow any privileges since the slave would lose material advantage of his masters care.

The Slavery Commissioner for Pemba, J. P. Farler, attributed the sluggish pace of emancipations to coincidence with the growing seasons. Farler stated that there were fewer emancipations during the growing season, but the pace of emancipation picked up after the end of the growing season. With emancipation, Farler also complained that there was an increased problem of vagrancy. The Slavery Commissioner lamented that the "ordinary African does not like to work."94 Freedom, then, was more of a curse than a blessing for the slaves. Farler admitted that, to stem the tide of vagrancy on Pemba, he regularly enforced article 6 of the decree that required slaves to prove they had a means of supporting themselves before being granted freedom. Slaves applying for freedom were required to prove that they had a contract for employment with a private individual. If they did not have this, a contract for employment was arranged with a government owned plantation. This arrangement brought criticism from the Society of Friends Mission on Pemba, and the practice was eventually discontinued. However, to fill the void, Farler stated that the police became more active in arresting vagrants.

\footnotetext{
${ }^{92}$ Great Britain, Correspondence Respecting Slavery and the Slave Trade in East Africa and the Islands of Zanzibar and Pemba, Cmd. 593, (May 1901), 2.

${ }^{93}$ Ibid., 4.

${ }^{94}$ Ibid., 9.
} 
The binding stipulations of the 1897 decree that, in essence, compromised the emancipation of the African slaves elicited heated criticism from many other humanitarian groups and individuals. On 12 April 1897 Bishop Alfred Tucker wrote in The Times that the proposals in the decree "practically bind the women in closer and more cruel fetters." 95 He also criticized the measures in the decree that hindered the movements of runaway slaves and found it problematic that the decree did not apply to the mainland territories of the Sultan. On 14 April 1897 Donald Mackenzie also wrote to The Times denouncing the decree for allowing harem slavery. Mackenzie also condemned the anti slavery decree for granting compensation to Arab slave holders. $^{96}$

Following this early vociferation against the decree, the BFASS followed suit. On 12 May Chas Allen, the Secretary of the BFASS, wrote to The Times as well. In his letter, Allen also criticized compensation as morally bereft since most of the slaves were taken in raids or kidnaped. In addition, he pointed out that the negation of the legal status of slavery was a hollow concept since it did not apply to the inmates of the harem, women. ${ }^{97}$

The BFASS was informed of the actual workings and problems of the decree through its contact with Theodore Burt of the Society of Friends Industrial Mission on Pemba. Burt and Henry Newman setup the mission in January 1897 to train and educate emancipated slaves in Pemba. Burt was also a corresponding member of the BFASS.

In Burt's letters to the BFASS, he pointed out that the emancipation was slowed down by the

${ }^{95}$ Anti-Slavery Reporter, April and June 1897, 90.

${ }^{96}$ Ibid.

${ }^{97}$ Ibid., 98. 
process of adjudication..$^{98}$ In Pemba, slaves had to go to trial on that island then again on Zanzibar if they wished to claim freedom. Burt found that slaves were not informed of their rights and local officials interpreted the decree in their own way. For example, on Pemba, Burt found several female slaves who had been imprisoned as runaways. On questioning the local liwali or governor, he was told that, "women don't know that they can be free." ${ }^{.99}$ Burt brought up the matter with slavery commissioner, Farler, who subsequently released a number of the slaves, but curiously added that Muslim law governed Pemba in regard to slavery.

Many of the leading journals in England also criticized the decree. For example, The Manchester Guardian on 13 May found fault with the decree for allowing concubine slavery and giving the slave holders compensation. The paper went on to call Hardinge an upholder of slavery and point out the contradiction of Salisbury's earlier call to end the slave trade as a justification for building the Uganda railway and his present acceptance of defacto slavery.

On 21 May the BFASS along with the Society of Friends convened a conference in tandem with members of parliament supportive of the organizations. The purpose of the meeting was to bring forth information concerning the question of slavery in Zanzibar and Pemba in light of the recent decree abolishing the legal status of slavery. The conference was chaired by the MP John Kennaway and included the MPs C. W. Dilke, Arthur and Joseph Pease and J. W. Wilson and also, Bishop Tucker and Donald Mackenzie.

Tucker informed the gathering of some of the main weaknesses of the decree. He stated that slave owners were given permission to search mission stations for runaway slaves and given the assistance of askaris or African police in hunting them. For Tucker, it made more sense to

\footnotetext{
${ }^{98}$ Ibid., November and December 1897, 244-245.

${ }^{99}$ Ibid., August and October, 1897, 183.
} 
abolish slavery on the mainland possessions of the East African coast, where the machinery of administration was entirely British, than to abolish it only on Zanzibar and Pemba. Tucker also considered the decree to have worsened the condition of women by allowing harem slavery. At the close of the meeting, Dilke suggested that he and John Kennaway should cooperate in drafting a question to be put to the government concerning the decree. Joseph Pease also indicated that he had already given notice of an amendment on the Foreign Office estimates that would be tied to the question of slavery in Zanzibar and Pemba. ${ }^{100}$

Following the meeting, the BFASS sent two minutes to Salisbury, passed by the organization on 4 June and 23 June, criticizing the decree. The minutes stated that the 1897 decree was inconsistent with the ideals of complete abolition and it protested against the provisions of the decree that granted compensation and sanctioned harem slavery. ${ }^{101}$

On 21 May, protest against the decree moved to parliament. True to his word, Sir Charles Dilke asked the Under Secretary for Foreign Affairs whether the present arrangements concerning slavery and fugitive slaves would continue on Zanzibar. ${ }^{102}$ Curzon answered that since slaves could gain freedom by leaving the ten mile strip of the Sultan's mainland territory, the provisions regarding fugitive slaves on Zanzibar and Pemba would remain. ${ }^{103}$

Kennaway followed up Dilke's question by asking Curzon whether the provisions regarding runaway slaves contradicted the Brussels Act that obligated signatory powers to give certificates

\footnotetext{
${ }^{100}$ Anti-Slavery Reporter, April and June, 1897, 107.

${ }^{101}$ Ibid., 114-115.

${ }^{102}$ Great Britain, Parliamentary Debates, Commons, $4^{\text {th }}$ ser., vol.49 (1897), col. 1025. ${ }^{103}$ Ibid.
} 
of freedom to slaves entering their territories. ${ }^{104}$ Curzon replied that Kennaway's interpretation of the Brussels Act was incorrect. The allocation of certificates of freedom was not binding and it only applied to slaves freed under conditions defined by the Brussels Act alone. ${ }^{105}$

From this point on, the $\mathrm{FO}$ was subjected to a continual barrage of questions in parliament concerning the fugitive slave question on the ten mile strip of the Sultan's territories on the mainland. On 28 May, in the House of Commons, for example, Dilke asked Curzon whether British subjects were required to surrender fugitive slaves within the ten mile strip. ${ }^{106}$ Curzon replied that it was up to the discretion of the British Administrator and added that the abolition of the legal status of slavery was confined to the insular domains of the Sultan not the mainland. ${ }^{107}$

Utilizing an earlier tactic, on a vote to complete the expenses for the British embassies and missions abroad on 24 June, J. Pease called for a reduction in the sum as a protest against fugitive slave problem on the mainland possessions of the Sultan of Zanzibar. ${ }^{108}$ The measure did not carry.

On 28 June Dilke carried on the attack by questioning the legality of the returning fugitive slaves to their masters. Dilke went on to produce a memorandum from the British superintendent of police at Mombasa asking a British missionary, E. G. Smith, to aid in returning a runaway slave from Lamu. ${ }^{109}$ Dilke then condemned British anti slavery policy in East Africa. Curzon

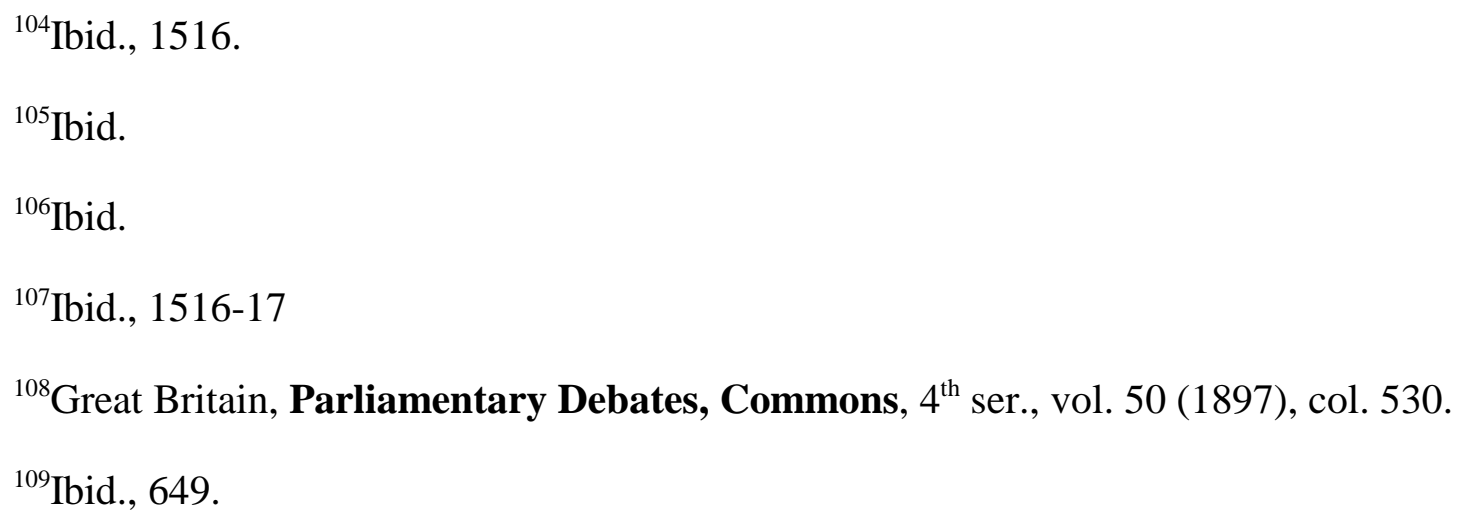


replied that the documents related to a policy on the mainland that had ceased to exist since December 1896. ${ }^{110}$

On 6 December 1897 a deputation from the BFASS met with Salisbury to deliver a memorial and discuss slavery in Zanzibar in light of the decree in $1897 .{ }^{111}$ The main points of criticism from the society were the provision in the decree sanctioning concubine slavery, compensation to slave holders and the delegation of powers of adjudication of the emancipation process to Zanzibari courts. The Society called for complete and absolute abolition and withdrawal of the concubine clause.

The problematic decree cast its shadow in other ways. The fugitive slave problem on the East African coast was a reflection of the contradictions of the 1897 decree ending the legal status of slavery. The British government did not wish to further alienate Arab slave holders on the coast. However, British missionaries on the coast were actively engaged in abetting fugitive slaves. So, the British government acquiesced and aided in efforts to return fugitive slaves. On 19 February 1889 Colonel Euan-Smith had formally issued a warning to British missionaries not to harbor runaway slaves. $^{112}$

The controversy over East African slavery would continue though numerous debates in parliament and memorials to the Foreign Office. On 19 July 1901, Dilke, with the support of J. Pease, actually moved for a reduction in the salary of Britain's Consul-General in East Africa by 100 pounds as a form of protest against the continuance of slavery on the Zanzibar and Pemba

${ }^{110}$ Ibid.

${ }^{111}$ Anti-Slavery Reporter, November and December 1896, 251-53.

${ }^{112}$ Anti-Slavery Reporter, April and June 1897, 129. 
and the mainland of East Africa within the ten mile strip. ${ }^{113}$

Eventually the institution of slavery was formally abolished on 6 July 1909. As Moses Nwulia has stated, the major reasons for British ${ }^{114}$ tardiness regarding the formal abolition of slavery were due economic and political concerns. ${ }^{115}$ The FO felt that the immediate end of slavery would lead to impoverishment for many Arab slave owners ${ }^{116}$ and would cause political instability in an area where British control was not firmly entrenched. The British government feared the prospect of impoverished "Mohammedan" former slave holders switching allegiance to the Germans in neighboring German East Africa. ${ }^{117}$ Political and economic factors also buttressed a cultural belief in the temperate vicissitudes of East African slavery. As late as 1905 a Sub-Commissioner in the EAP familiar with coastal slavery would state that, "slavery in East Africa is merely a term and people at home appear to be under a delusion as to the actual condition of things relative to slavery in these parts."

Contradictory anti-slavery idology of the humanitarian lobby paralleled ambivalent British policy regarding slavery. On the one hand, it extolled the virtues of free labor against slavery while calling for colonialism. This was evident in the Society's attacks on East African slavery and slavery in the EAP. But, this quixotic quest against slave labor proved contradictory

${ }^{113}$ Great Britain, Parliamentary Debates, $4^{\text {th }}$ ser., vol. 97 (1901), col. 1028.

${ }^{114}$ The Foreign Office administered the East Africa Protectorate until 1905 when the Colonial Office assumed control.

${ }^{115}$ Nwulia, Britain and Slavery in East Africa, 179.

${ }^{116}$ This position was echoed by J. W. Barth, who would later chair the 1912-13 Native Labour Commission, in a memorandum on the subject. J. W. Barth to Stewart, 27 June 1905, CO $533 / 1$.

${ }^{117}$ G. N. Curzon Confidential, 29 December 1896, CAB/37/43/58.

${ }^{118}$ MacDougal to Stewart, 26 May 1905, CO 533/1. 
when faced with the actual use of slave labor as porters in caravans. Much like earlier BFASS arguments that extolled the inefficiency of slave labor in sugar production, the moral criticisms of British use of slave porters simply were not utilitarian. The counter argument, free labor, would also be evident in the issue of forced labor during the 1912 Native Labour Commission as we shall discuss in chapter five. However, the importance of this anti-slavery initiative during this time period reflects a continuity of techniques. The newly amalgamated Anti Slavery Society and Aborigines Protection Society would continue with the tactics of applying pressure in parliament and upon the various organs of the British colonial state and writing petitions in its criticisms of bonded labor in the dawn of the twentieth century. Humanitarian of criticism forced labor for private purposes, the extension of the debate over slavery, would serve as the moralizing ideology of progressive colonialism as the controversy over bonded labor in Kenya matriculated. 


\section{Chapter 5}

\section{"Making the Lazy Nigger Work:"1 The 1912 Native Labour Commission and Forced Labor in the EAP During WWI}

The labor problem in East Africa continued into the $20^{\text {th }}$ century. The techniques of humanitarian agitation against bonded labor in East Africa endured over the issue of forced labor.

Humanitarian groups like the ASAPS were drawn to the issue of government recruitment of forced labor for private individuals. For the ASAPS, forced labor for private purposes was the reification of pro slavery ideology. This issue would flare up as the result of a labor commission report in the EAP in 1912. However, the problem of bonded labor in East Africa, or more specifically British reliance upon forced labor, was a reflection of the deeper structural relationship between African labor and the colonial state. Subsequently, it would be a recurring theme of colonial rule during this time period.

\section{European Settlers and the Problem of African Labor}

In 1906 and 1908 two pledges from the CO ensured the exclusivity of the central highland area in Kenya for European settlers. The so called "Elgin Pledge," named after the Secretary of State for the colonies, the Earl of Elgin, reserved the so called, "White Highlands," for European settlement. Despite the pledge, the under capitalized settlers required even more state intervention as they struggled with the problem of African labor. ${ }^{2}$

${ }^{1}$ From title of article by J. H. Harris of the ASAPS discussing the 1912 Native Labour Commission. J. H. Harris, "Making the Lazy Nigger Work," Contemporary Review (June 1914). Harris borrowed the title from the testimony of one of the witnesses to the Native Labour Commission.

${ }^{2}$ For further study, consult: M. P. K. Sorenson, Origins of European Settlement in Kenya, (Nairobi: Oxford University Press, 1968); Errol Trzebinski, The Kenya Pioneers 
Sir Charles Elliot, the EAP's second Commissioner (1901-1904) after Hardinge encouraged European settlement during his tenure. ${ }^{3}$ With the extension of the Uganda railway to Kisumu on Lake Victoria, European settlement was encouraged as a way of paying of the debt of construction, plus making the railway economically feasible. By 1905 there were 500 to 600 European settlers in Kenya which eventually increased to 2000 by $1907 .{ }^{4}$ Most settled on the Uasin Gishu Plateau, Central Highlands and the Rift Valley. Some of the early settlers came from Britain; however, there was, also, a large contingent that came from South Africa in 1903. Although a few settlers were large wealthy land owners like Lord Delamere (Hugh Cholmondeley) and Ewart Grogan, most were small scale mixed farmers.

Due to their meager financial means, the settlers demanded that the state intervene to help them prosper in this new environment. As the famed voice of the European settlers, Elspeth Huxley, enunciated so clearly, "The government had a certain obligation to the European farmer. They had deliberately invited him into the country to sink his capital and make his home there... They had, therefore, an obligation to help him obtain native workers." ${ }^{5}$ Settler demands were justified by racist beliefs in the innate laziness of Africans. Africans were thought to be lazy and only by making them work hard would the virtuous benefits of civilization and a strong work

(London and New York: W. W. Norton and Company, 1986); Elspeth Huxley, White Man's Country: Lord Delamere and the Making of Kenya (London: Chatto and Windus, 1948); Brian Du Toit, The Boers in East Africa (Westport and London: Bergin and Garvey, 1998); Philip Mbithi and Carolyn Barnes, The Spontaneous Settlement Problem (Nairobi: East African Literature Bureau, 1975); Bruce Berman, Control and Crisis in Colonial Kenya: The Dialectic of Domination (Athens: Ohio University Press, 1990); G. H. Mungeam, British Rule in Kenya (Oxford: Clarendon Press, 1966).

${ }^{3}$ Sorenson, Origins Of European Settlement, 36.

${ }^{4}$ Anthony Clayton and Donald Savage, Government and Labour in Kenya, 1895-1963 (London: Frank Cass, 1974), 21.

${ }^{5}$ Huxley, White Man's Country, 215. 
ethic be bestowed upon the children of Ham. As Avery Johnson, a European settler, stated, the "male native lives, in most cases in a state of idleness, while their women do all of the heavy work of the field and household besides rearing of the family for him. ${ }^{6}$ The aforementioned Ewart Grogan boldly stated that the "African native . . . is fundamentally inferior in mental development and ethical possibility ... to the white man."7 Grogan proposed compulsory labor as the only good system for regulation of Africans.

To promote their interests, settlers formed the Convention of Associations in 1910 to better lobby for special rights before the $\mathrm{CO}$ and the state. The Convention was actually an amalgamation of several colonist associations. Ewart Grogan was the first president. In its early years, the governor and official members of attended the sessions of the Convention, and it was able to exert a degree of influence on government.

Settler demands translated into structural efforts on the part of the state to push Africans into the wage economy. The 1902 Crown Lands Ordinance legislated the alienation of land for Europeans. $^{8}$ Europeans could lease land from the crown for up to 99 years and could buy up to 1000 acres of land for homestead farming. All African land became crown land and was slated to become reserves. Between 1906 and 1912 the state demarcated reserves for Africans that also hemmed them in as a potential source of labor. In addition to the demarcation of the reserves, the state also moved to institute measures that ultimately pushed African labor within the reserves towards wage employment. By 1902 the state had implemented a hut tax, which was a tax on African dwellings. The payment was two rupees. Besides the indirect coercion into the

6“"East African Natives,” East African Standard, 24 Dec 1920.

${ }^{7}$ Quoted in Berman, Control and Crises in Colonial Kenya, 21.

${ }^{8}$ Sorenson, The Origins of European Settlement, 63.

Page -115- 
labor market, the tax was also a visible sign of cooption. ${ }^{9}$ Africans were now tax paying subjects of the crown.

In 1906 the Administration passed the Masters and Servants Ordinance designed to regularize and discipline the African labor force that squatted on European farms. Based upon legislation originally used in Transvaal, the ordinance stipulated that employers hire laborers on an annual contract and allow them to cultivate land on their estates free of charge. In return, Africans had to work for at least 3 months or longer at a wage agreed to by both parties. ${ }^{10}$ The labor contract bound Africans to work. A penal clause in the ordinance penalized Africans with fines or jail terms for breach of contract. These measures were meant to directly affect African labor outside the reserves.

\section{Accumulation and Government Forced Labor}

There has been a lot written on modes of production in Africa. ${ }^{11}$ The mode of production is

${ }^{9}$ Berman, Control and Crises in Colonial Kenya, 53.

${ }^{10}$ Ibid., 150.

${ }^{11}$ Geoffrey Kay, Development and Underdevelopment: A Marxist Analysis (London: Macmillan, 1975); Robin Law, "In Search of A Marxist Perspective on Pre-Colonial Tropical Africa," Journal of African History 19 (3)1978; Barry Hindess and Paul Hirst, Pre-Capitalist Modes of Production (London: Routledge and Kegan Paul, 1975); Bruce Berman and John Lonsdale, "The Development of the Labour Control System in Kenya, 1919-1929," Canadian Journal of African Studies 14(1), 1980, 37-54; Aiden Forster Carter, "The Modes of Production Debate," New Left Review 107, 1978: 47-73; H. Bernstein and J. Depelchin, "The Object of African History," History in Africa 5, 1978, 1-19; 6 1979, 17-43; Etienne Balibar and Louis Althusser, Reading Capital (New York: Pantheon Books, 1970); Harold Wolpe, ed., The Articulation of Modes of Production (London: Routledge and Keegan Paul LTD., 1980); Wim van Binsbergen and Peter Geschiere, eds., Old Modes of production and Capitalist Penetration (London: Routledge and Keegan Paul LTD., 1985). Emmanuel Terray, Marxism and Primitive Societies (New York and London: Monthly Review Press, 1972); Frank Ellis, Peasant Economics (New York: Cambridge University Press, 1988); Claude Meillassoux, Anthropology of Slavery (Chicago: University of Chicago Press, 1991). Also look at the entire

$$
\text { Page -116- }
$$


usually understood as an abstract concept encompassing empiricist data that describes a society in terms of its economic base, juridico-political structure and ideological base for a specific epoch. ${ }^{12}$ The term is abstract in the sense that it is a theoretical concept that describes concrete functions of a society, generally, economic, political and ideological, that are necessary for the existence of social relations or the dominant way labor is organized in a specific time period. ${ }^{13}$ The mode of production then is socially defined and is a combination of the relations of production or class structure, determined by access to resources, and the forces of production (technology, raw material, etc. ). The mode of production is historically existent and varies according to different material conditions and requisite class relations. Varying modes of production differ according to the way they appropriate surplus or the production above current needs for simple reproduction for a particular society. ${ }^{14}$ Surplus does not necessarily have to be realized in purely economic terms but could also be extracted socially. Depending upon the particular mode of production different structures whether ideological, political or economic, will be more dominant. For instance, under the capitalist mode of production economic structures are more dominant even though ideological and or political structures still play a role in the formulation of social relations. Surplus produced by a class of workers is appropriated by another class who own the means of production necessary for reproduction and reinvested back into production to constantly revolutionize or expand output. ${ }^{15}$ Under pre capitalist, communalist

issue of the Canadian Journal of African Studies 19 (1) 1985 which was devoted to addressing issue on the "tired" debate over modes of production.

\footnotetext{
${ }^{12}$ Terray, Marxism and Primitive Societies, 97-98.

${ }^{13}$ Bernstein and Depelchin, "The Object of African History," 5.

${ }^{14}$ Frank Ellis, Peasant Economics: Farm Households and Agrarian Development, 48.

${ }^{15}$ Ibid., 48-49.
} 
modes of production ideological structures will be more dominant even though political factors or economic factors will still play a more subordinate role in the reproduction of social relations. The amount of surplus is small and will be redistributed communally. There may be more than one mode of production within a social formation or society at large, and variations in modes of production are determined by the appropriation of surplus labor or labor beyond what is necessary for the worker to reproduce himself. ${ }^{16}$ For example, in pre capitalist, communalist modes of production surplus is distributed collectively. Contrastingly, under the capitalist mode of production surplus is redistributed according to class.

The efficacy of the concept of mode of production developed out of the Althusserian Marxist tradition during the early 1970s. One of Althusser's contributions was to show that humanistic readings of Marx's work, represented by Marxists like Herbert Marcuse and Jean Paul Sartre, stressed the Hegelian or subjective aspects of Marxism in their reading of Capital which reduced this "science" to a philosophy. ${ }^{17}$ Basically, a humanistic reading of Marxism stressed human consciousness or agency over material factors. For Althusser, this led to a reading of Marx's early works that overly emphasized the dialectic, alienation or consciousness. Althuser's program, then, was to reread the text, Das Kapital, and essentially emphasize or reorient Marxist studies towards the science of Marxism posited in modes of production.

According to Althusser, Marx's own "scientific" method of analysis of political economy was in fact not so much the embodiment of materialism but theoretical abstraction. ${ }^{18}$ This would affect the historicism inherent in the conceptualization of modes of production. Althusser states:

\footnotetext{
${ }^{16}$ Hindess and Hirst, Pre Capitalist Modes of Production, 25.

${ }^{17}$ Robert, Bocock, Hegemony (London and New York: Tavistock Publications, 1986), 14

${ }^{18}$ Althusser and Balibar, Reading Capital, 50-51.

Page -118-
} 
"this goes to show that there is nothing incomprehensible in the paradoxical fact that Marx treated his original method of analysis as a method that already existed even in the instant when he invented it."19 According to Althusser, Marx's analysis of political economy was taken to be the real object or "raw material" of this political economy when in fact it was a theoretical construction of the object of knowledge, the political economy. ${ }^{20}$ In essence, historical materialism was the "scientific" aspect while Marx's historicism or the dialectic, essentially the trajectory of successive modes of production, was the theoretical construct. The major contribution of Marx's analysis of political economy was to show that classical economists like David Ricardo and Adam Smith conceived political economy as an eternal fixed, ahistorical abstraction of the economic categories of capitalism. ${ }^{21}$ Marxism, the theoretical construct, merely added a historicist element to this description of capitalism. Marxist theory was an attempt to describe the relationship between the social totality as a whole and its constituent elements or modes of production in a hierarchical manner.

For Althusser, this historicist element in Marx's analysis could be traced to epistemological assumptions in the theory. According to Althusser, knowledge is a theoretical process involving the interaction of thought and "raw material," the object of knowledge, which itself is determined by the interaction. ${ }^{22}$ Consequently, Althusser states, knowledge must be conceived as a product or theoretical construct since it cannot be disassociated from a reading of the text. ${ }^{23}$ However,

\footnotetext{
${ }^{19}$ Ibid, 51

${ }^{20}$ Ibid., 51, 55.

${ }^{21}$ Ibid., 91.

${ }^{22}$ Ibid., 43.

${ }^{23}$ Ibid., 7.
} 
this conception of knowledge differed with traditional Marxist interpretations which construed knowledge as the embodiment of material factors. To meet this challenge, Althusser points out that the validity of theoretical constructs contain their own inherent methods of self validation. Althusser states that "theoretical practice is indeed its own criterion, and contains in itself definite protocols with which to validate the quality of its product ..."24 Essentially, Althusser contended that theoretical concepts cannot be readily grasped by simple observation. Instead, "empirical" observations will be of phenomena or dependent upon the senses that are produced by the underlying "real" theoretical concepts. In relation to modes of production, human knowledge is the product of successive modes of production. It reproduces its own validity first in the form of an ideology and then a science. For Althusser, then, Marxism, in particular the abstract conception of time, was the ideological conception of practice to yet be proven by the science of historical materialism. ${ }^{25}$ Relating to modes of production, according to Althusser, the problem with Marxist analysis was its linear description of the unfolding development of modes of production within a social formation. ${ }^{26}$ Althusser counters, however, that each mode of production has its own temporality as reflected in its relative autonomy from the whole. He argues that the concept of history, itself, is an epistemological construction. Accordingly, the development of modes of production is multi linear and does not progress according to a set pattern. In other words, as stated earlier, there can be more than one mode of production within a social formation and with articulation between different modes of production it was given that one would give way to the other. They could articulate and both change but remain or one could

${ }^{24}$ Ibid., 59.

${ }^{25}$ Ibid., 60. According to Althusser, Marx like Hegel periodized his description of political economy but never questioned the very conceptual validity of time itself.

${ }^{26}$ Althusser, and Balibar, Reading Capital, 322.

Page -120- 
give way to the other. But, it was not a given that primitive communalism is followed by feudalism and then capitalism. And, as Robin Law has stated, Althusser emphasized the contradictions that arise out of the relations production as the force that drives the process of change from one mode of production to another. ${ }^{27}$

In the field of African studies, modes of production enjoyed popularity during the 1970s to mid 1980s as a way of attempting to explain why, in contrast to Europe, capitalism in Africa was not able to revolutionize or overcome social formations encompassing pre capitalist modes of production, in essence, the peasantry. The concept of "articulation" or the process of interaction between pre capitalist modes of production and capitalism became the conceptual marker for interpreting the inability of capitalism to overcome the peasantry in Africa. For instance, G. Kay looks at the penetration of merchant capital into Africa as instrumental in blocking the path to the development of capitalism in Africa. ${ }^{28}$ Goran Hyden examined the role of "uncaptured" peasantry affecting the process of capitalist development. ${ }^{29}$ The efficacy of articulation spawned a plethora of studies which sought to illuminate, further, these various pre capitalist modes of production in Africa. The word speak of modes of productions came to include such conceptual monikers as slave mode of production, lineage mode of production in its lexicon. ${ }^{30}$

Despite its heyday in the early 1980s, modes of production eventually fell victim to the vitality of its own proliferation. Descriptive terms such as lineage mode of production, slave

\footnotetext{
${ }^{27}$ Robin Law, "For Marx, But With Reservations About Althusser: A Comment on Bernstein and Depelchin," History in Africa 8, 1981, 248.

${ }^{28}$ Kay, Development and Underdevelopment, 95.

${ }^{29}$ Göran Hyden, Beyond Ujamaa in Tanzania: Underdevelopment and the Uncaptured Peasantry (Berkeley: University of California Press, 1980).

${ }^{30}$ On the "slave mode of production" see Claude Meillassoux, Anthropology of Slavery, Paul Lovejoy, Transformations in Slavery (Cambridge: Cambridge University Press, 1990).
} 
mode of production and the Asiatic mode of production were applied dogmatically but did not always fit the empirical reality. For instance, in some conceptualizations of the lineage mode of production elders appropriated surplus from the youth through labor or initiation fees; however, some scholars saw this same appropriation as redistribution through bride wealth. ${ }^{31}$ Reduced to its vulgar form, it is no longer in vogue in African studies as an effective conceptual framework. As Berman has written, one of the problems with modes of production was its "abstract emptiness." 32 The abstract terminology of modes of production was used liberally to describe empirical categories of the labor process as modes of production. This resulted in many instances in the proliferation of various abstract conceptualizations of modes of production superimposed upon forms of production. ${ }^{33}$ As Frank Ellis points out "peasant household production is never a mode of production in itself, it is always located in a larger society where a particular dominant mode prevails." ${ }^{34}$ Consequently, in the case of the peasantry, Ellis states that social reproduction would still correspond to the dominant mode of production in the society at large even if the peasant has a limited ability to reproduce themselves independently of that dominant mode.

Berman also points out that modes of production, with its structuralist origins, does not give space for human agency and is teleological. Consequently, it does not adequately describe the role of the state in the process of articulation. Structuralism, according to Berman, does not

${ }^{31}$ Gavin Kitching, "Suggestions for a Fresh Start on an Exhausted Debate," Canadian Journal of African Studies 19 (1) 1985, 117.

${ }^{32}$ Berman and Lonsdale, "The Concept of Articulation and the Political Economy of Colonialism," in Berman and Lonsdale, Unhappy Valley, 130.

${ }^{33}$ Ibid.

${ }^{34}$ Ellis, Peasant Economics, 49. 
explain why the state takes different forms in different epochs and geographical regions. ${ }^{35}$

Moreover, as we will soon discuss, the structuralism of modes of production does not adequately illuminate the "relative autonomy" of the state that is grounded in the contradictions of political economy of its rule. ${ }^{36}$ The traditional Marxist view of the state defines it as an instrument of class rule which merely ensures the reproduction of institutional apparatuses necessary for the protection of private property rights. ${ }^{37}$

Berman is accurate in his criticisms of modes of production. However, despite these obvious weaknesses, it is still useful, simply, as a heuristic tool. ${ }^{38}$ In terms of colonial Kenya the concept of articulation is useful in illuminating the contradictions of the political economy of colonial rule. But, instead of taking a grandiose approach that attempts to understand the imposition of metropolitan capital upon pre colonial modes of production in Kenya, we can ask more simple questions. What role does settler poverty play in the desire for African labor? How does this settler desire for African labor affect the overall legitimacy of the colonial state? And, lastly, how does the poverty of the colonial state, itself, affect the desire for African labor? These are questions that go beyond the simple opposition of the extension of capitalism and pre capitalist modes of production. Modes of production is no longer valid as a dogmatic ideological framework upon which to rest our meta theories. However, it is useful in terms of the questions that it raises.

\footnotetext{
${ }^{35}$ Berman, Control and Crises in Colonial Kenya, 13.

${ }^{36}$ Ibid., 14.

${ }^{37}$ Ellis, Peasant Economics, 55.

${ }^{38}$ Gervase Clarence-Smith, "Thou Shalt Not Articulate Modes of Production," Canadian Journal of African Studies 19 (1) 1985, 19.
} 
Much has been written of coerced labor under colonial rule in Kenya. ${ }^{39}$ European settlers lacked adequate capital to disassociate pre-capitalist forms of labor organization without state intervention. Settlers offered low wages as incentives for Africans to experience the benefits of wage labor. Many Africans, however, still had access to land and went into the labor market only if they were poor or for specific reasons which determined the extent of their engagement. Most had limited need for the amenities that wages could buy in a market economy. As a result, the colonial state had to enter the market and force Africans to labor through laws and penal sanctions. This was a process of so called "articulation" or linkage, between metropolitan capital and pre capitalist social formations in Kenya. Some facets of pre colonial modes of production were absorbed while others were expunged.

In this role, the colonial state in Kenya acted as an instrument of primitive accumulation for the settlers but, also, for the state, itself. ${ }^{40}$ The state extracted surplus from the African peasants through appropriation of land, livestock, taxation, forced labor and unequal transporting and

\footnotetext{
${ }^{39}$ Anthony Clayton and Donald Savage, Government and labor in Kenya(London: Frank Cass, 1974); R. M. A. van Zwanenberg, Colonial Capitalism and Labor In Kenya(Nairobi: East African Literature Bureau, 1975); Sharon Stichter, Migrant Labor in Kenya: Capitalism and African Response (London: Longman, 1982); Marjorie Dilley, British Policy in Kenya Colony(New York: Barnes and Noble, 1966).; Raymond Buell, The Native Problem in Africa(New York: MacMillan Company, 1928).; Gaving Kitching, Class and Economic Change in Kenya(New Haven: Yale University Press, 1980).; Robert Tignor, The Colonial Transformation of Kenya: The Kamba, Kikuyu and Maasai(Princeton: Princeton University Press, 1976).; J. Forbes Munro, Colonial Rule and The Kamba: Social Change in the Kenya Highlands 1889-1939(Oxford: Clarendon Press, 1975).; Bruce Berman and John Lonsdale, "Crises of Accumulation, Coercion and the Colonial State: The development of the Labour Control System in Kenya, 1919-1929 Canadian Journal of African Studies 18(3) 1984; Robert Maxon, Struggle For Kenya (London and Toronto: Associated University Press, 1993); Bruce Berman, Control and Crisis in Colonial Kenya (Athens: Ohio university Press, 1990).

${ }^{40}$ Paul Zeleza. "Dependent Capitalism and the Making of the Kenyan Working Class During Colonialism,” (PhD. Dissertation, Dalhousie University, 1982), 66. I borrow the concept primitive accumulation to only refer to the similar violent methods of accumulation of capital during the pre industrial phase British commercial expansion.
} 
marketing of produce. In the process, the peasant household subsidized the extraction of surplus. In the case of forced labor, women and children were used, in part, on certain types of labor projects allowing men the opportunity to support the state through wage employment. However, in the process of articulation, artifacts of the pre-capitalist modes of production, were not destroyed, but recast in new ways as an apanage of the emergent colonial economy. The construction and appropriation of "communal labor" by the colonial administration represented one such element of this process. Reliance upon communal labor represented the limits of capitalist articulation with pre capitalist forms in Kenya Colony. In essence, it was a reflection of the poverty of the colonial state.

Communal labor also represented an aspect of the "politics of ligitimation." ${ }^{41}$ The colonial state in Kenya was in one sense a reflection of the institutions and practices that defined the political economy of Kenya but to some extent it also shaped them. ${ }^{42}$ The state as arbiter of opposing modes of production sustained legitimacy to the extent through which it appeared to be enmeshed in these seemingly passive, impersonal institutions and discourse. As evidenced from our discussion of the BFASS, slavery was no longer acceptable as a form of labor organization. Consequently, when the state in Kenya responded to the issue of forced labor it did so against the backdrop of slavery as, institutionally, morally wrong.

The poverty of Europeans in Kenya but also the poverty of the colonial state were inducements for the coercion of African labor. The justification was that forced labor taught Africans habits of industry or was simply a continuation of traditional duties. Consequently, government forced labor for so called communal purposes, although, nominally, associated with

\footnotetext{
${ }^{41}$ Berman, Control and Crises in Colonial Kenya, 54.

${ }^{42}$ Ibid., 9.
} 
pre colonial African labor requirements, was co-opted and recast as an appendage of reforming capitalism ${ }^{43}$ with the overriding moral sanction of benevolence residing squarely with the trusteeship aims defined by British colonial rule. In essence, however, communal labor was a reflection of the manipulation of customary law that justified the appropriation of African surplus for the state. Africans called up for communal labor were not paid wages.

The colonial state in Kenya institutionalized government forced labor through laws and prevalent paternalistic thinking. The ideological justification determined that Africans were lazy and would not respond to higher wages because they did not have wants. ${ }^{44}$ Hence, it would be better to reinforce lower wages with forms of coercion to turn Africans labor out into the market and engender their capitalist work ethic.

Laws institutionalized the structural development of coercion. The Village Headmen Ordinance of 1902 gave headmen the powers to turn out labor for the upkeep of any public road adjacent to headman's village. The Roads in Native Reserves Ordinance of 1910 mandated that men could be turned out for work on roads for a period of up to six days per quarter. ${ }^{45}$ The Native Authority Ordinance of $1912^{46}$ allowed colonial chiefs to call out forced labor for so

${ }^{43}$ Stichter, Migrant Labour, 37. Stichter states that forced labor in the service of peripheral capitalism resembled pre-capitalist labour which societies would normally give to a conquering nation, the so called tributary labor.

${ }^{44}$ Berman, and Lonsdale, "Crisis of Accumulation, Coercion and the Colonial State: The Development of the Labor Control System, 1919-1929" in Lonsdale and Berman, Unhappy Valley, 106.

${ }^{45}$ Clayton and Savage, Government and Labour in Kenya, 42.

${ }^{46}$ van Zwanenberg, Colonial Capitalism and Labor in Kenya, 113-115. The amendment to the Masters and Servants Ordinance in 1919 introduced a labor inspectorate stop the abuses of labor supply and regularize the use of force. The amendment to the Native Authority Ordinance in 1920 provided that any man could be coopted for up to sixty days in any one year for three out of the twelve months in a year. 
called "communal" purposes. Under Section 8(h) of the ordinance able bodied men could be called out for six days a quarter or 24 days a year "to work in the making or maintaining of any water course or other work constructed or to be constructed or maintained for the benefit of the "community." These "other works" could include projects like building minor irrigation schemes, light dams and bridges that were deemed part of the traditional obligations of an ethnic group. ${ }^{47}$ This labor was unpaid but theoretically was supposed to be in the interests of the community. This was forced labor for state purposes. The Registration of Natives Ordinance of 1915, which legislated the kipande system of labor identification as a means of control, helped to formalize labor control.

The ulterior purpose of communal labor was borne out by the statements of the Chief Native Commissioner, John Ainsworth in 1918. On the topic of communal labor, the CNC stated that: ...Chiefs and Native Authorities can demand that their people undertake such works as roads, irrigation, etc., in so far as such works are for the good of the whole community ... and in this procedure lay our hope that the young man will prefer to leave their reserves for work outside, one reason being that such work in the reserves is not paid for. ${ }^{48}$

Besides the macro level exploitation of African labor, there were internal contradictions with the working of the forced labor ordinances in Kenya. During a sitting of the 1912 Native Labor Commission, one colonial chief, Ndeda of Kavirondo, admitted that, "if a man had no property or 'shamba' in the Reserve and did no work he would be sent out by force." ${ }^{\prime 9}$ Wealthy peasants or relatives of the chief or headmen could get out of the labor requirement. Forced labor, as an $533 / 273$.

${ }^{47}$ Ibid.,

48“"Memorandum RE A Meeting On The Labour Question," 18 September 1918, CO

${ }^{49}$ East Africa Protectorate, The East Africa Protectorate, Report and Evidence of the Native Labour Commission, 1912-1913, (Nairobi: Government Printer, 1913), 158.

Page -127- 
institution, mainly effected poor households for another reason. More wealthy peasants could simply expand production to meet the needs of taxation and fines while traditional authorities, colonial chiefs and the new salaried elite, mission educated African administrative workers, were normally exempt. ${ }^{50}$ Some ethnic groups, like the Kamba, became so successful in expanding production that they began to employ their own workers. ${ }^{51}$ For example, during the 1912-1913 Native Labour Commission hearings, G. H. Osborne, a District Commissioner for Machakos, estimated that there were roughly one thousand Kikuyu working for the Kamba. He added that, "undoubtedly, the Kikuyu found this more attractive than working for Europeans." 52

Despite these coercive measures, African peasants were able to remain a dynamic force and were not simply compliant actors. Forced labor developed in an environment of uneven capitalist penetration in Kenya. ${ }^{53}$ As a result, it was unreliable, to some extent, due to the colonial state's ultimate reliance upon African production and also African chiefs. This destabilized the equilibrium of the relatively autonomous state in Kenya. Compulsion that resembled artifices of slavery went against the ideals of trusteeship and endangered the legitimacy of the colonial state. This brought protest from the humanitarian lobby and from within Kenya from lower level administrative officials.

Nevertheless, labor supply was crucial to the development of the settler economy and the

${ }^{50}$ van Zwanenberg, Colonial Capitalism and Labor in Kenya, 113-115.

${ }^{51}$ Forbes Munro, Colonial Rule and the Kamba, 83, 85.

${ }^{52}$ Native Labour Commission, 1912-1913, 80.

${ }^{53}$ Paul Zeleza, "Labor Coercion and Migration in Early Colonial Kenya," in Zageye Abebe and Shero Shubi, eds., Forced Labor and Migration(New York: Hans Zell Publishers, 1989), 162-63 
colonial state. Reliance upon forced labor was a reflection of the financial weaknesses of both the European settlers and the colonial state. The perception of labor shortage was one of the crucial factors that precipitated the periodic labor crises between 1909 and 1939. However, in some respects, these shortages were influenced more by inadequate transport or communication than actual lack of man power. ${ }^{54}$ As Roger van Zwannenberg has mentioned, the outcry against forced labor from humanitarians was not an outcry against the colonial economic system which demanded coercion. ${ }^{55}$ Instead, it was more of a condemnation of the symptoms of the political economy in colonial Kenya with an eye towards the preservation of the trust principle. As such, it served as a justification for the continuance colonial rule.

\section{Background To The Labor Controversy of 1912-1913}

Whereas British supremacy was not as entrenched in East Africa as the rhetoric of colonial rule, this was not the case with the belief in the ameliorative certainty of British trusteeship on the home front. The role of the British in East Africa, as stewards of the African populace towards higher levels civilization, was widely accepted. The only questions that remained pertained to the custodial nature of this control. In 1913, following the report of the Native Labour Commission, another storm of protest erupted that brought this question of trusteeship into focus.

In 1912 the simultaneous arrival of more European farmers coupled with the development of various government projects like the Thika extension of the Uganda railway, the construction of a

\footnotetext{
${ }^{54}$ Gavin Kitching, Class and Economic Change in Kenya: The Making of an African Petit Bourgeoisie 1905- 1970 (New Haven: Yale University Press, 1980), 247.

${ }^{55}$ van Zwanenberg, Colonial Capitalism and Labor, 128-129.

Page -129-
} 
piped water delivery system in Mombasa and the building of the Mombasa harbor works all served to create the appearance of a labor shortage. ${ }^{56}$

Up to this time period, the government had assisted the private sector in procuring labor, but the assistance had not been systematic nor legally consistent. The question of the government's role in recruiting labor and the larger issue of trusteeship regarding the African populations exploded and a labor commission was created to delve into the matter.

Even before the 1912 Native Labour Commission, labor incidents frequently exposed the contradictory relationship between European planter interests, the $\mathrm{CO}$ and the colonial state concerning labor. In 1907 two Africans were publicly flogged by Captain Ewart Grogan, then president of the Colonists Association. The event led to the formulation of the so called "Labor Rules" concerning European employers and African workers set out by the newly minted Native Affairs Department under A.C. Hollis. The incident also caused some controversy in parliament. Winston Churchill was parliamentary Under Secretary for the CO, at the time, and had just visited Kenya where he had seen some labor abuses first hand. Consequently, Churchill gave full support to the "Labor Rules" by the Native Affairs Department defining the extent to which government would assist in recruiting labor for private individuals.

The "Labor Rules" were more concerned with the conditions of labor under contract. They stipulated the employer's requirements regarding labor, such as providing accommodation, blankets, medical care and so forth. The text of the Labor Rules complete with the opinion of Winston Churchill and another general memorandum on labor by Hollis plus a circular memorandum instructing chiefs not to compel labor were sent to the $\mathrm{CO}$ for approval. Although

\footnotetext{
${ }^{56}$ Clayton and Savage, Government and Labour in Kenya, 55.
} 
Elgin, the $\mathrm{S}$ of $\mathrm{S}$, approved of the documents, it is interesting to note that at this point both Hollis and Churchill as, Undersecretary, accepted government recruitment of labor for good employers. $^{57}$

Despite the "Labour Rules" the state was ultimately concerned with supporting settler capital. For example, On 23 March 1908 a group of settlers led by Lord Delamere marched on the governor's house to demand solutions to the labor problem. The marchers demanded, among other things, a repeal of the Labor Rules, a reorganization of the Native Affairs Department with a head more favorable to the settlers viewpoint and more government help in acquiring labor. The governor, Sir James Hayes Sadler, responded to the settlers demands the following day. He stated that "encouragement" was the government's official policy but a circular would be issued on this matter. Sadler also stated that government departments would conform to the Labour Rules. The governor added that although he was sympathetic with the rise in wages, he could not fix a legal maximum but would try to check positive wage pressure. Sadler also suspended Delamere and one of his cohorts from the Legislative Council and sent the CO another memorandum from Hollis concerning the labor situation. Following this mini crisis, however, the administration assuaged the settlers by instituting a poll tax in 1908 . This was a tax on unmarried young men who did not pay hut tax and was designed to push them into wage labor for payment of the tax.

Hollis's memorandum had detailed some of the worst abuses of forced labor and African labor, in general. According to Hollis, he was first drawn to study African working conditions when he discovered a number of dead Kikuyu laborers on a road leading from an Asian

\footnotetext{
${ }^{57}$ Ibid., 34.
} 
contractor's camp at Londiani. Subsequent investigations led Hollis to more abuses. In one case, workers were detained for fourteen days for refusing to labor for an unpopular employer.$^{58}$ Hollis attributed the labor shortage to bad management, noting that employers with good reputations were still able to obtain labor. To remedy the abuses of compulsion, Hollis issued a circular disallowing coercion by government departments.

Hollis' memorandum caused a stir in the CO. It coincided with the British led campaign against the Belgian abuses in the Congo. Hollis' memorandum, therefore was a potential source of embarrassment. The CO sat on the issue for a while. During the interim, Sadler reemphasized in another circular that government policy was to aid in recruiting labor. At this point, the CO finally responded in August 1908. In the despatch the S of S, now Lord Crewe, instructed the governor that it was not the policy of the government to recruit African labor. As much as this seemed to be a definitive stance on government recruitment for private individuals, this direction in policy was subsequently weakened by the Village Headmen Ordinance and another circular from Sadler that both encouraged the chiefs to turn out labor. The ambiguity of policy would surface later in other incidents ultimately presaging the 1919 Northey Crisis. Sadler's immediate successors as governor, Sir Percy Girouard and H.C. Belfield, actually reverted back to the practice of government "encouragement" of labor for private individuals and instructed chiefs to assist in labor recruitment. Shadowing the Native Labour Commission, several planter interests would also present their complaints about the labor situation in Africa. Many of their complaints reflected the core issues or concerns that planters expressed during the Native Labour Commission.

\footnotetext{
${ }^{58}$ Ibid., 37.
} 
On 23 February 1909, for example, a deputation of fibre companies in the EAP met the Governor of the EAP, Sir James Sadler to ask for the importation of indentured Indian labor to meet their labor demands. ${ }^{59}$ Sadler eagerly cabled the S of S on 25 February requesting 1200 Indian men and their families for three year indentures. ${ }^{60}$ The $\mathrm{CO}$, fearing that indentured labor would bring up questions of slavery in parliament, denied his request. ${ }^{61}$

Labor demands did not abate. Following the demands of the defacto European settler legislative body, the Convention of Associations, ${ }^{62}$ the administration appointed a commission of inquiry on 13 August 1912 to look into the labor problems. It convened initially on 19 September 1912. However, while the Native Labour Commission was still meeting, business interests in the EAP petitioned the $\mathrm{CO}$ to redress the labor situation.

In November 1912 a letter from British East Africa Fibre and Industrial Company complained to the Secretary of State for the Colonies about the shortage of labor. ${ }^{63}$ On 16 December 1912, a deputation of notable coast and highland planting interests in the EAP met with the Secretary of State for the Colonies, Lewis Harcourt, to discuss labor supply problems in Kenya. ${ }^{64}$ The deputation consisted of E. H. M. Leggett representing the British East Africa Corporation, A.J. B. Wavill representing the Nyali Sisal Plantations, Lawrence Phillips of the

\footnotetext{
${ }^{59}$ The companies were the Deutch English Company, the Afro-American trading and Navigation company, British East Africa Fibre and Cullinan's Factory.

${ }^{60}$ Sadler to Secretary of State for the Colonies, Telegraph, 25 February 1909, CO 533/58.

${ }^{61}$ Secretary of State for the Colonies to Sadler, 12 April 1909, CO 533/58.

${ }^{62}$ The official legislative body was the Legislative Council.

${ }^{63}$ C. C. Caunt to Lewis Harcourt, 5 November, 1912, CO 533/113.

${ }^{64}$ Minutes of Proceedings at a Deputation to the Secretary of State for the Colonies on the East African Labour Question, 16 December, 1912, CO 533/113. 
London Chamber of Commerce, Colonel Owen Thomas of the East African Estates, the MP, C. H. Guest, Lord Cranworth and E. Powys Cobb. The purpose of their visit was to discuss how to better obtain labor in the protectorate for the plantations, how to deliver it more efficiently to the plantations and whether a system of registration of African laborers should be introduced. Around these three themes the delegates touched upon taxation, wages, standardized contracts and government recruitment of labor.

The deputation felt that the government needed to systemize labor recruitment by establishing a recruiting agency for African labor and an Employers Labour Federation that would administer the labor when recruited. In terms of taxation, the deputation called for an additional collective tax on African tribes according to the economic prosperity of the collective. This was basically a way to penalize more prosperous ethnic groups into wage labor.

Harcourt made it clear to the deputation, however, that "government recruitment of labor ... has always been refused as a policy by my predecessors and I have continued that policy." ${ }^{65} \mathrm{He}$ went on to indicate that government recruitment of labor was seen by the Africans as forced labor since they felt compelled not to refuse an overture from a government official.

Concerning the deputation's collective tax proposal to induce Africans to work, Harcourt countered that increased taxation would also increase poverty. He, instead, proffered that the wants of the Africans should be increased as a better method of driving them to market. The importance of this meeting was that it showed that the CO, under the administration of Harcourt, was definitely opposed to legislation that hinted of forced labor for private profit. The demands of the deputation were also symptomatic and emblematic of the feelings of many European

\footnotetext{
${ }^{65}$ Ibid.
} 
planters regarding African labor. This would come up clearly during the hearings of the Native Labour Commission.

\section{The 1912-13 Native Labour Commission}

Due to settler outcry from organizations like the Convention of Associations, the acting governor Charles Bowering appointed a Native Labour Commission in 1912. The Native Labour Commission published its field of investigation on 1 October $1912 .{ }^{66}$ As mentioned previously, the original mandate of the commission was to delve into the labor problems in colonial Kenya. Specifically, it was commissioned to address some of the difficulties European settlers experienced in acquiring labor. ${ }^{67}$ The scope of the Labour commission was also intended to examine the reasons for the shortage of labor, African wages, the desirability of indentured labor, taxation and squatter farming.

The field of inquiry of the Native Labour Commission report was relatively all inclusive and delved into many topics such as recruitment, wages, taxation and employer treatment of workers. The initial composition of the Labour Commission included two officials of the administration, three settlers and two missionaries but no Asian or African representatives. ${ }^{68}$ The original Native Labour Commission was chaired by Judge Jacob. W. Barth and included a District Commissioner, F. G. Hamilton, G. Williams, a European farmer and chairman of the Convention

\footnotetext{
${ }^{66}$ The terms of reference were to enquire into the reasons for the shortage of African labor utilizing evidence from both employer and employee; examine the effect of the Administration upon the labor question and to look into wages and other subjects which affected labor.

${ }^{67}$ Clayton, and Savage, Government and Labour in Kenya, 55-64.

${ }^{68}$ W. McGregor Ross, Kenya From Within: A Short Political History (London: Frank Cass, 1968), 98. 
of Associations, B. G. Williams, a Nairobi solicitor, G. Brandsma, a Roman Catholic priest of the Mill Hill Mission, and J. W. Arthur of the Church of Scotland's Kikuyu mission. Later C. C. Bowring, the governor's Chief Secretary and H. Wessels, a farmer and land agent, plus Lord Delamere, a prominent farmer, were added to the Commission. The Commission published its itinerary and called for evidence.

One of the remarkable features of the Commission was the breadth of its evidence. Of the 284 witnesses who were called, 205 were European with 64 Africans and 15 Asians. Some notable witnesses were J. D. Ainsworth, Dr. Norman Leys, W. McGregor Ross, A.C. Hollis, G. A. Northcote and M. Beech, all, at the time, employees of the colonial state.

Many of the Africans complained about the abusive powers of the headmen and colonial chiefs in turning out labor. For example, one African witness, Ochola Omolo of Kavirondo, stated that people went to work only because the chiefs forced them to go at the government's bidding. However, he added that he, himself, went out to work on his own initiative. ${ }^{69}$ When African labor was needed, the ususal harbinger of this information was the askari or African policeman. The askari was not an idle threat of compulsion. Another African witness, Mwangi wa Waide, added that Africans were beaten by chiefs if they refused the order to work. In addition, Mwangi stated that chiefs regularly recruited labor for Europeans. ${ }^{70}$ One theme was consistent and clear in many of the depositions given by Africans.

If the chief received an order to send men out, he sent his own 'askari' to get them from different kraals until the number required was obtained, and when they got the order to come out they never refused. 'How could I refuse if I get an order from my chief?' The chief only gave the order if the government or a European

\footnotetext{
${ }^{69}$ Native Labour Commission Report, 129-130.
}

\footnotetext{
${ }^{70}$ Ibid, 120.
} 
required him to do so, and no one else..$^{71}$

Most of the administrative chiefs who gave depositions stated that they did not force labor out of the reserves, but merely "encouraged" those who needed to work to go out and labor. In addition, as one chief, Nederebo wa Kichui, mentioned, most laborers went out voluntarily anyway. According to the chiefs, the laborers that left the reserves were never the wealthy and were compelled to work by a desire to improve their economic standing to either pay a dowry or tax.

However, some chiefs admitted that they used force to obtain labor. Chief Shivachi of North Maragoli stated that although he did indeed use force on occasion the "force" was simply the threat of "paternal curse."72 Another "Native Authority," Chief Keri of Nyakech was more forthcoming. He simple admitted that force was necessary for the chiefs to maintain their authority. Several chiefs stated that they did not force labor at all but merely encouraged "people to go out and work for money to pay their taxes and generally to increase their wealth."73

Employers, on the other hand, complained most about the need to regularize labor recruitment, institute a pass system and decrease wage levels. Lord Delamere was arguably the most prominent settler in the EAP at the time due to his large scale land holdings and his high political visibility. Delamere argued that African labor problems were due, mainly, to, the fact that, Africans still maintained access to the land. Subsequently, they had no need of wages. In this direction, he denounced the Provincial Commissioner of Nyanza, John Ainsworth, for

\footnotetext{
${ }^{71}$ Ibid., 121.

${ }^{72}$ Ibid., 269.

${ }^{73}$ Ibid., 271.
} 
encouraging African production which he felt retarded their progress towards wage labor. Besides impeding African labor for European planters, Delamere felt that the development of wealthy African peasants had other unforseen consequences. According to Delamere, one ethnic group, the Kamba, had profited so well under Ainsworth's encouragement of produce for export that, "they were now to be found drunk from one end of the country to other." ${ }^{\text {,4 }}$ To make labor procurement more efficient, Delamere proposed a system of identification in the form of a badge. This would be worn by Africans indicating if they had paid their taxes.

J. E. Jones a representative for the Coast Planters Association echoed concerns for the coastal planters by emphasizing that labor recruitment had to be standardized. Jones went so far as to call for government recruitment of labor to make the process systematic. Jones also called for higher taxation and a pass system.

The statements of many of the planters reflected the haphazard nature of labor recruitment and the labor problem in Kenya. Mr. H. Scott of Limuru complained that DCs did not inform chiefs that it was their duty to cull labor out of the reserves. W. H. Caine, also of Limuru, complained in his deposition to the commission that on the one occasion he asked for labor, the local DC did not help him at all. He felt that chiefs were quite willing to recruit labor if they knew the order was a clear and unequivocal directive from the government. Caine proposed regularization of recruitment through the formation of a Native Affairs Department.

On the other hand, W. Bowker, a rancher in the Kedong Valley, did not have any labor problems at all. ${ }^{75}$ By allowing Africans to squat on his land, he was able to acquire a confident

${ }^{74}$ Ibid., 91.

${ }^{75}$ Bowker was also involved in a 1906 public flogging of two Africans by Captain Ewart Grogan, President of the Colonists Association at the time. Clayton and Savage, Government 
supply of labor. However, he stated that he was aware of labor problems in other districts, and he proposed government instituted forced labor for all Africans as a solution. An ostrich rancher, A.C. Hill of Machakos, stated, however, that he experienced difficulty in acquiring labor and was forced to rely primarily on the squatters on his land. He too proposed the formation of a labor bureau to solve the problems of recruitment. H. Tarlton, a cattle and ostrich rancher of Kiambu, had labor problems as well. But, for Tarlton, colonial chiefs caused the labor recruitment problems by intimidating African laborers going out of the reserves with threats of extortion. Tarlton thought that the administrative officers were quite helpful in recruiting labor.

Tarlton proposed increasing taxation and the creation of a labor bureau as solutions to the labor problem. Prophetically, he also proposed instituting unpaid forced labor on public works projects in the reserves as a means of driving Africans to wage employment for Europeans. As he stated, "provided that the natives were not paid for doing such work it would lead to their coming out of the reserves and working for wages in preference., ${ }^{, 6}$ T.A. Wood, a labor agent out of Nairobi, echoed this same theme. Wood stated that Africans should be put to work building public roads and public works generally in the reserves without pay. He considered that this would have the effect of pushing Africans to work for Europeans at "reasonable wages."

Missionary officials likewise displayed a range of attitudes towards the labor problem in the EAP. For example, the Reverend Father Bernhard, the Superior of the St. Austins Roman Catholic Church, admitted that his mission operated on the principle of encouraging Africans to work for Europeans. In Bernhard's opinion, much of the labor shortage could be attributed to the

and Labor, 33.

\section{${ }^{76}$ EAP, Native Labour Commission Report, 19.}

Page -139- 
chiefs who did not show enough favor towards Europeans. Indeed, according to Bernhard, the chiefs had too much power and "after all were only savages and were not competent to be allowed any authority."77 To stimulate labor out of the reserves, he called for increased taxation in the form of a wife tax and for government to issue definite instructions stating that chiefs should encourage Africans to seek wage employment. Bernhard also called for mandatory clothing of Africans as a way of inculcating market desires. As he stated, "it was little less than a disgrace that practically naked savages should be allowed in town; they should be made to wear cloths, in order to buy which they would be induced to work, and would incidentally assist us.",78 He also did not think that Africans would respond to higher wages by coming out of the reserves to work. Father Bernhard ended his testimony stating that a system of unpaid forced labor on development projects would also help to augment the supply of labor moving out of the reserves.

Contrasting this view point, Reverend C. F. Johnson of Machakos felt that decreasing the size of the reserves and increasing taxation would only cause further pauperization in the reserves by impacting the poor and the landless more heavily. His statements were reinforced by the evidence form A. Barlow of the Scottish Mission in Nyeri district. Barlow worried that increased taxation and other measures designed to cull Africans out of the reserves were based upon a fallacious viewpoint that African males were lazy and needed to be pushed to work. Barlow argued that African males were indeed very busy clearing ground for new gardens and generally doing work associated with male labor. Increasing the strains upon laborers to work for

\footnotetext{
${ }^{77}$ Ibid., 79 .

${ }^{78}$ Ibid.
} 
Europeans would only serve to weaken the African family. ${ }^{79}$ Barlow also worried about the negative effects of "civilization" upon the African workers outside the reserves without the rejuvenating influences of missionary endeavor.

Administrative officials, likewise, displayed varied attitudes towards the perceived labor crisis. John Ainsworth, the Provincial Commissioner for Nyanza, stated that he did not believe there was a labor shortage in Nyanza. ${ }^{80}$ Although he was absolutely in favor of Africans working, Ainsworth stated that he emphasized African production in the reserves. Ainsworth added that his administrative officers were instructed not to recruit African labor. In contrast to many witnesses, Ainsworth did feel that increased wages would push more Africans towards wage employment out of the reserves. In addition, he was against a pass system and any reduction of the reserves.

Contrasting Ainsworth, G. Northcote, District Commissioner of Nyeri, stated that "it was justifiable for the superior race to force the inferior to work for it, on the ground that benefits would accrue to the latter." ${ }^{\prime 1}$ He attributed the labor shortage to the increasing wealth of different African ethnic groups and a lack of strong inducement to work. As a prescription, Northcote advocated a pass system coupled with increased taxation and a diminution of the reserves.

Several government officials attributed the dearth of labor to maltreatment of African workers by European employers. Between June to September 1912, Norman Leys, a medical

\footnotetext{
${ }^{79}$ Ibid., 227.

${ }^{80}$ Ibid., 129.

${ }^{81}$ Ibid.,51.
} 
doctor, examined two thousand African men at Fort Hall brought to him by recruiters for work. From these men, Leys discovered that many did not want to work due to poor working conditions. These included unreasonable working hours, floggings, bad food and water plus unfair deductions from their wages for offences like poor work habits. The ones who did not wish to work constantly pestered Leys do give them a poor medical evaluation, so they could get out of the labor assignment.

Leys found that there was also coercion of labor. If laborers did not wish to turn out for work, the chief or headman would simply seize a goat. Leys made it clear, though, that headmen were simply responding to the pressure to turn out labor emanating from the administrative officials. As he stated, "when headmen are summoned to Bomas and lectured, as they frequently are-it is the avowed government policy-on their duty of supplying labour for both Government and private employers." 82 Leys went on to state that "encouragement" of African labor in actuality meant compulsion. He concluded his statement by reemphasizing that improved working conditions would stimulate African labor.

Many of the government witnesses were in accord that cutting down the size of the reserves and raising taxation would only increase poverty. According to A. C. Hollis, it was mainly the old, the young and the poor who were forced out to labor. So measures designed to increase labor outflow would adversely impact this group.

The question of wage incentives to labor supply occasioned an illuminating testimony from W. McGregor Ross, the director of the Public Works Department. The Public Works Department or PWD was at the root of the labor problem since it competed with the European

\footnotetext{
${ }^{82}$ Ibid., IX.
} 
settlers for man power. From Ross' own figures, he stated that the PWD used on average about forty thousand workers per year. ${ }^{83}$ Ross noted that the PWD experienced labor problems when the work required conflicted with harvest time because Africans would not want to work when their own fields needed to be tended. Consequently, he came to the conclusion that Africans would not respond to higher wages in periods of labor shortage because the hard choice for them was between eating or working.

The final resolutions of the Native Labour Commission ranged upon a wide number of topics. These included recommendations for a further demarcation of reserves, the appointment of a Chief Native Commissioner and the delimitation of squatter farming. ${ }^{84}$ With respect to forced labor, the Commission stated that the Roads in Native Reserve Ordinance of 1910 and the Native Authority Ordinance of 1912 both had negative effects upon African labor. The Commission found that the forced labor turned out under these ordinances created a disdain for labor among the Africans. Consequently, the Commission recommended paid labor at the market rate for work on public roads. Regarding porterage, the Commission hoped that with the construction of more roads the need for porterage would decline. It also called for the substitution of wheeled and pack animal transport for African porters.

In terms of recruiting, the Commission called for the abolition of the professional recruiter as source of many labor abuses. In addition, the Commission called for constitution of government labor camps where potential employers could obtain labor. The Commission concluded that some of the reasons for the shortage of labor resulted from vague and general instructions from

\footnotetext{
${ }^{83}$ Ibid., 28.

${ }^{84}$ Ibid., 333-335.
} 
administration in regards to recruitment of African Labor and the wealth of African tribes like the Kamba. For instance, the commission found extreme variation in the commands of district officers when it came to recruiting African labor. ${ }^{85}$ Some admitted that they assessed their chiefs according to the amount of labor they turned out for wage employment. While others only allowed voluntary labor into wage employment. Consequently, one of the main findings of the Commission, which aroused the ire of the humanitarians, was the Commission's acceptance that, "definite instructions to be issued by Government to District Officers to encourage Natives out to work." 86

The finished report was well received by the Convention of Associations. Although the report had been completed in August 1913, the CO did not receive a copy of the report from Sir Henry Belfield, the governor of Kenya, until March 1914. The Commission's findings were given a stamp of approval by Belfield, who added that he personally approved of "encouragement" of African labor. As he commented to the CO concerning the report, "It is of the utmost importance that all officers entrusted with duties of native administration should impress upon the people the desire of the government that their young men should go out to work." ${ }^{, 87}$ This contradicted Harcourt's own despatch in December 1912 and was sure to cause agitation. The CO, waited two months to respond to the findings of the Native Labour Commission and Belfield's statements. ${ }^{88}$ The response from Harcourt reiterated his earlier

${ }^{85}$ Clayton and Savage, Government and Labour, 58.

${ }^{86}$ Native Labour Commission Report, 335.

${ }^{87}$ Maxon, Struggle for Kenya, 69.

${ }^{88}$ Ibid., 68. 
despatch and added that using administrative officials to impress African labor could lead to dangerous consequences. ${ }^{89}$ Despite the language, the tardy response allowed the initiative to shift to the humanitarian lobby.

The use of "encouragement" by the colonial state to stimulate African turn out alarmed the humanitarian lobby. For, as Norman Leys, who would become a prominent member of the humanitarian establishment, pointed out, "encouragement" was simply a thin veil for compulsory labor. $^{90}$ When the ASAPS learned of Belfield's statement, it petitioned the Secretary of State, Lewis Harcourt, through a lengthy letter on 11 June 1914. In the letter the ASAPS appealed to Harcourt for a definitive declaration that "encouragement" of African Labor for private purposes "is a form of slavery that will not therefore be tolerated." 91 The ASAPS argued that any form of recruitment was bound to lead to compulsion. Harcourt, in a letter to the society on the 9 July, concurred with this position, after some initial consternation, ${ }^{92}$ and in a subsequent letter on 17 July 1914 allowed his opinion to be published in the news papers by the ASAPS. ${ }^{93}$

Harcourt's statement that forced labor was tantamount to slavery had been an important coup for humanitarian organizations like the ASAPS which had been consistently petitioning the CO to end all forms of "slavery" in Kenya since the assumption of colonial control. ${ }^{94}$

${ }^{89}$ Ibid., 70.

${ }^{90}$ Ross, Kenya From Within, 99.

${ }^{91}$ Buxton to Harcourt, 11 June 1914, CO 533/148.

${ }^{92}$ Minute by Harcourt, 15 June 1914, CO 533/1148.

${ }^{93}$ Butler to J. H. Harris, 17 July 1914, Box G 132, File: "Labour and Land,” BFASS/APS, Rhodes House Library.

${ }^{94}$ As shown in chapter four, the ASAPS had been petitioning the British government to end slavery on the coast of Kenya since the 1880's. This activity extended to other forms of 
Harcourt's agreement with the ASAPS that forced labor was tantamount to slavery would become an important victory for the organization and a bane for the $\mathrm{CO}$ in the future. For, in future controversies over forced labor, the ASAPS would return to Harcourt's festering statement in the colonial body, trusteeship, as a sacred point of reference. Harcourt's pronouncement on forced labor, besides acquiescing in the ASAPS's point, also represented the ideal position of trusteeship.

The forced labor issue came up subsequently in parliament as a result of the Native Labour Commission. Beginning in April 1914, several MPs, most notably, J. Wedgwood and T. E. Harvey, began to pepper Harcourt concerning different aspects of the Native Labour Commission report. ${ }^{95}$ This continued on 16 June 1914 when Sir John Jardine asked the S of S, Harcourt under which conditions compulsory labor for public works could be demanded in the EAP. ${ }^{96}$ Gulland, the Lord Treasurer, replied that labor could be commissioned for duties under the Native Authority ordinance for up to 6 days a quarter.

The labor questions on the EAP came up again during a debate in parliament on 28 July 1914. On that day, T. E. Harvey, a Liberal MP, asked Harcourt about assurances concerning the size of the reserves, taxation and compulsion. He was concerned that the Native Labour Commission report indicated that Europeans wished to turn Africans into warrens for their

"slavery" as defined by the ASAPS such as forced labor for private purposes when the Colonial Office assumed control of Kenya in 1905.

${ }^{95}$ For example, Edmund Harvey asked Harcourt on 10 February whether he would publish a White Paper on the Commission. On 20 April, Sir William Byles asked Harcourt whether he was aware of certain allegations of mistreatment of African labor contained in the deposition of one of the witnesses. On 8 May Wedgwood asked Harcourt about forced education and slavery. CO 533/146.

${ }^{96}$ Great Britain, Parliamentary Debates, Commons, $5^{\text {th }}$ ser., vol. 63 (1914), col. 1797. Page -146- 
farms. ${ }^{97}$ In addition, W. Joynson Hicks, following consultation with the ASAPS, asked Harcourt whether he was in agreement that forced labor was tantamount to slavery. ${ }^{98}$ Harcourt's reply was more muted as he toned down some of the recommendations of Commission's report. ${ }^{99}$ Concerning encouragement, Harcourt basically reiterated Crewe's statement of 1908, when he stated that "Our officers in the East Africa Protectorate, though it is their proper duty to provide information as to where employment may be available, do nothing which savors of or suggests in the matter of recruitment."100 He did state, ambiguously, however, that it was sometimes difficult to discriminate between advice, persuasion and compulsion in these matters.

Governor Belfield presented an edited summary of Harcourt's views before the Convention of Associations meeting in July. He attached his own statements imploring administrative officials to encourage African labor to the end of Harcourt's statement. Significantly, Belfield did not publish Harcourt's despatch as Sadler had done before with Crewe's statement. In regards to “encouragement” Belfield's summation of Harcourt's views omitted the concise and clear disavowal of government recruitment of labor that was evident in Harcourt's despatch. For example, Harcourt's original despatch stated that,

Our officers ... though it is their proper duty to afford information as to where employment may be available, do nothing which savours of or suggests government compulsion in the matter of recruitment. ${ }^{101}$

${ }^{97}$ Great Britain, Parliamentary Debates, Commons, $5^{\text {th }}$ ser., vol. 65 (1914), col.1154.

${ }^{98}$ Ibid., 1177.

${ }^{99}$ Ibid., 1191.

${ }^{100}$ Ibid.

${ }^{101}$ Clayton and Savage, Government and Labour, 62. 
Belfield's summation, on the other hand, stated that

Definite instructions have been issued by His Excellency to provincial and District Officers to the effect that they are to lose no opportunity of explaining to the natives the advantages of going out to work and are to refrain from making any observations which may leave the people under the impression that government is not anxious that they should do so. ${ }^{102}$

The Convention of Associations viewed Harcourt's despatch with consternation. The stage was set for a possible conflict with the CO, but the outbreak of WWI forestalled it.

\section{World War I}

During World War I there were extensive problems surrounding the issue of bonded labor. Chattel slavery actually became an issue again. The war took the protectorate by surprise. Within the military, there was a high demand for African labor to serve as carriers. The conscription and use of African carrier troops led to extensive abuses. As a result, the ASAPS, through their parliamentary allies, took up the their historic mantle in criticism of bonded labor in East Africa. The episode of conscription during the war was also significant for it set a trend for the use of forced labor, despite the official disapproval from Harcourt and Crewe, that would continue after the war and set the stage for the labor crisis in 1919-1920.

With the start of the war in 1914, military authorities organized African labor into military carrier corps under the leadership of O. F. Watkins as commander. Initially, recruitment into the Carrier Corps was voluntary. Although "volunteering" sometimes involved trickery. ${ }^{103}$

${ }^{102}$ Ibid., 64.

${ }^{103}$ One report from the Kisii district of Nyanza province stated that on one occasion Africans were recruited for Carrier Corps by calling them out to cut grass and then enrolling them into the Carrier Corps. Donald Savage and J. Forbes Munro, "Carrier Corps Recruitment in 
However, by early 1915 , the state switched to coercion when the demand for recruits proved greater than the amount forthcoming despite the offering of higher wages. ${ }^{104}$ Initially, the state used the Native Authority Ordinance and martial law to impress carriers. This led to abuses as Africans were sometimes simply rounded up by chiefs and headmen and sent into service. ${ }^{105}$ Africans convicted of petty crimes and even contractual employees who might be suddenly accused of "loafing" were also pressed into service. ${ }^{106}$ The need for carriers kept increasing. By 1915, the military needed approximately 3000 African carriers per month. As a result, the Native Followers Recruitment Ordinance was enacted in September 1915. The ordinance gave district commissioners the power to instruct chiefs and headmen to supply recruits for carrier service under threat of penalty. This ordinance put a lot of pressure on chiefs and headmen to procure labor. Failure to carry out orders to procure labor was punishable with a fine of 600 rupees or 6 month imprisonment.

In addition, as a result of African recruitment, settlers increased their traditional demands for better flow of labor supply from the reserves. As an aspect of this, communal forced labor within the reserves increased markedly. For example, in August 1915 in Seyidie Province, local African labor was exempted from Carrier Corps duty so as to man local transport to Mombasa. ${ }^{107}$ In 1915, due to settler demands, the administration passed one of the resolutions of the 1912 Native Labour Commission, the Registration of Natives Ordinance. This established a pass system of

British East Africa, 1914-1918,” Journal of African History 7 (2) (1966): 317. ${ }^{104}$ Clayton and Savage, Government and Labour, 82 . ${ }^{105}$ Ibid.

${ }^{106}$ Ibid.

${ }^{107}$ Savage and Munro, "Carrier Corps Recruitment," 323. 
registration for Africans that was designed to gain more control over the work force. The pass system was not implemented, however, until 1919.

Settler demands did not stop there. They also pressed for a reduction of carrier wages to be more commensurate with the lower wages offered to African farm workers. ${ }^{108}$ Although initially paid a much higher wage of 10 to 15 rupees per month with rations, the average wage of African carriers was eventually reduced to 5 to 6 rupees with rations. However, the range of pay varied depending on the duties of the carrier. ${ }^{109}$ With the passage of the Native Followers Recruitment Ordinance, settlers clamored for the ordinance to be used for recruitment of labor on private farms. ${ }^{110}$ The effect was to create an impression among Africans that they should remain in employment period. As Donald Savage and J. Forbes Munro state, " the favourite, and perhaps most effective, way for the young men to avoid the carrier corps was for them to take up employment with European settlers." ${ }^{111}$ Recruitment into the Carrier Corps was essentially state recruitment of labor for private purposes. One planter lamented that he could get African labor when recruiters for the Carrier Corps were in the vicinity, but Africans alighted as soon as the menace of internment passed. ${ }^{112}$ The average length of employment subsequently increased from 4 months to 8 to 12 months. The irony was that despite African willingness to engage in work on settler farms as a way of getting out of Carrier Corps duty, settler still were not able to

${ }^{108}$ Ibid., 321 .

${ }^{109}$ Geoffrey Hodges, The Carrier Corps: Military Labor in the East African Campaign, 1914-1918 (New York: Greenwood Press, 1986), 77.

${ }^{110}$ Savage and Munro, "Carrier Corps Recruitment," 322.

${ }^{111}$ Ibid., 329 .

${ }^{112}$ Hodges, The Carrier Corps, 95.

$$
\text { Page -150- }
$$


meet the wage demands. This was an indication, again, of the weakness of settler capital.

Carrier duty was extremely difficult and rife with abuses. Work was arduous and varied from railway and road construction, carrying loads to serving as servants, stretcher bearers, signal porters and machine gun and bomb carriers. ${ }^{113}$ Their food rations were often unsatisfactory and below the soldier's rations that British troops received. Rations of maize or beans to African carriers unaccustomed to the diet, coupled with poor food preparation, caused diarrhoea and dysentery. Many of the carriers came from areas were grain consumption was not common. The sudden switch to grain could lead to internal complications particularly if it was gritty or undercooked. This problem of rations was compounded by another factor. Africans received poor rations in comparison to Europeans because it was though that the food befit their status. In one case in April 1917, at the Nairobi Carrier Depot, Africans were purposefully given inferior beef by the veterinary officer because it was felt they could consume it without problems. ${ }^{114}$

Medical conditions were equally appalling. Dysentery, pneumonia and fevers killed men in droves. Dysentery, alone was responsible for 50 percent of the deaths by African Carrier Corps personnel. ${ }^{115}$ Pneumonia killed from 12 to 20 percent of carriers. ${ }^{116}$ Some ethnic groups, like the Nandi, experienced diseases with which they previously had no contact. ${ }^{117}$ The medical situation was exacerbated by inadequate care. There were not enough doctors and beds to care for all of

${ }^{113}$ Geoffrey Hodges, "Military Labour in East Africa and its Impact Upon Kenya," in Melvin Page, Africa and the First World War (New York: St. Martin's Press, 1987), 140.

${ }^{114}$ Hodges, The Carrier Corps, 128.

${ }^{115}$ Hodges, "Military Labour in East Africa," 143.

${ }^{116}$ Hodges, The Carrier Corps, 130.

${ }^{117}$ Clayton and Savage, Government and Labour, 85. 
the casualties.

In March 1917 the former PC of Nyanza province, John Ainsworth, was made Military Commissioner of Labour. ${ }^{118}$ With his appointment, the recruitment of African carriers increased dramatically. This also led to abuses as now DCs simply enforced recruitment by armed raids. Africans reacted with massive desertions and even rebellion. In 1914, the most serious the involved the Giriama, on the hinterland of the coast. ${ }^{119}$ As cynthia Brantley points out, it was not merely the war but earlier British efforts to force the Giriama into the labor market that were the root causes of the rebellion. ${ }^{120}$ Eventually, by August 1917, compulsory recruitment of African carriers stopped. By 1919, 73,057 men were demobilized. With the end of recruitment, reports of abuses began to filter back to London. During the war, the ASAPS had remained patriotically silent on the home front preferring, instead, to close ranks while Britain grappled with Germany. As Travers Buxton stated in a letter to the S of S Walter Long enquiring about Carrier Corps recruitment, "it is not our intention on this occasion to challenge the ethics of compulsion." ${ }^{121}$ As befitting the Society's historic role as a voice of protest against slavery in all its forms, it would be the issue of slavery that would initially draw them again into criticism of colonial labor practices in East Africa. Eventual ASAPS criticisms of Carrier Corps abuses were a reflection of their interest in bonded labor and a reflection of the problematic of free wage

${ }^{118}$ Ibid., 86.

${ }^{119}$ Savage and Munro, "Carrier Corps Recruitment," 310.

${ }^{120}$ Cynthia Brantley, The Giriama and Colonial Resistance in Kenya, 1800-1920 (Los Angeles and Berkeley: University of California Press, 1981), 100-112.

${ }^{121}$ Travers Buxton to Walter Long, 19 October 1917, Box G/132, BFASS/APS, Rhodes House Library, Oxford. 
ideology.

In August 1918 the ASAPS became involved in the issue of slavery in German East Africa. ${ }^{122}$ On 19 August Travers Buxton, the Parliamentary Secretary of the BFASPS, wrote to the colonial Secretary of State asking the CO to proclaim the end of the legal status of slavery in German East Africa and to ascertain the exact number of slaves. ${ }^{123}$ The letter was signed by a number of organizations including the National Free Church Council, Christ Church and the Weslyan Methodist Conference. According to Buxton, there were approximately 185,000 slaves in German East Africa. ${ }^{124}$ Alluding to Great Britain's moral status as a progressive colonial power, Buxton added that ending the status of slavery "would enhance still further her moral prestige among the peoples of Africa and indeed among the native races of the world." 125 Buxton then referenced a statement by Lord Cromer that condemned domestic slavery.

On 27 August, G. Grindle of the CO responded to Buxton's letter. He informed Buxton that the actual figures for slaves in German East Africa at the start of the war were approximately 70,000 to 80,000 , but 4,120 had since been freed. ${ }^{126}$ Grindle added that slave raiding and slave

\footnotetext{
${ }^{122}$ Travers Buxton to Walter Long, 19 August 1918, Box G/132, BFASS/APS, Rhodes House Library, Oxford.

${ }^{123}$ Ibid.

${ }^{124}$ Buxton got these figures from a FO Consular Report, 1912-13, on Trade, Commerce
} and the Economic Position of German East Africa in May 1915. The reports stated that the total number of household slaves in German East Africa was approximately 185,000. It stated the cost of liberating the slaves would amount to 400,000 pounds and would be of little benefit to the slaves anyway. "British Consular Report, 1912-13 on Trade, Commerce and Economic Position of German East Africa, Box G/132, BFASS/APS, Rhodes House Library, Oxford.

${ }^{125}$ T Buxton to W. Long, 19 August 1918, Box G/132, BFASS/APS, Rhodes House Library, Oxford.

${ }^{126}$ G. Grindle to T. Buxton, 27 August 1918, Box G/132, BFASS/APS, Rhodes House Library, Oxford. 
owning was fast becoming a thing of the past. ${ }^{127}$ On 6 September Travers Buxton of the ASAPS wrote to the Under Secretary of State disputing the slave number reports from the CO. ${ }^{128}$ Buxton thought the numbers were closer to 185,000 based upon a published report from the German government on 14 March 1914. ${ }^{129}$ The ASAPS continued with the push for freedom and before the war ended had enlisted the support of several Peers and MPs. ${ }^{130}$

Conscripted labor, mostly for the Carrier Corps, became an even bigger issue. By 1917 the ASAPS had been receiving reports of mistreatment of Africans in the Carrier Corps pertaining to flogging, malnourishment and improper medical care. ${ }^{131}$ P. A. Molteno, an MP with close ties to the ASAPS, took up the mantle of this debate. On 10 July 1917, Molteno asked the Under Secretary of State for War, I. Macpherson, whether the system of recruitment of carriers was voluntary and whether the rations and medical care were adequate. ${ }^{132} \mathrm{He}$ also asked whether the casualty figure of 10,000 per month for the Carrier Corps was accurate. Macpherson erred and replied that there was no ordinance governing compulsion in recruitment of carriers but it was due to the war effort. He added, however, that "the procedure adopted has resulted in minimum

${ }^{127}$ Ibid.

${ }^{128}$ Travers Buxton to Under Secretary of State, 6 September 1918, Box G/132, BFASS/APS, Rhodes House Library, Oxford.

${ }^{129}$ Ibid.

${ }^{130}$ ASAPS to Lord Kinnaird, 31 July 1918, Box G/133, BFASS/APS, Rhodes House Library, Oxford.

${ }^{131}$ Emma Wardlow Best to Buxton, 30 Nov 1917, Box G/132, BFASS/APS, Rhodes House Library, Oxford.

${ }^{132}$ Great Britain, Parliamentary Debates, Commons, $5^{\text {th }}$ ser., vol.95 (1917), col. 1720. 
of friction and hardship." ${ }^{133}$ Macpherson stated that rations were adequate. Africans received 1.25 pounds of flour, one pound of rice, for rice eaters, .25 pounds of beans, 112 pound of meat and $112 \mathrm{oz}$ of salt. ${ }^{134}$ On 13 July under further questioning from Molteno, Macpherson admitted his error and stated that there was an ordinance governing the recruitment of African carriers. ${ }^{135}$

On 19 July 1917 the jousting continued. Molteno asked Macpherson why the number of sickness casualties, 10,000 to 15,000 , were so high. ${ }^{136}$ Macpherson responded that it was due to malaria, pneumonia, Cerebro Spinal Meningitis and dysentery. At this juncture, Molteno suggested that perhaps the high rate of sickness for carriers was due to a deficiency in caloric intake. He pointed out that Macpherson's figures for African rations amounted to only 2,989.75 calories per day (2,557 for rice eaters). ${ }^{137}$ In comparison, British troops received 4,334 calories per day that was increased to 4,644 if the troops were in the trenches. Macpherson replied that there were other factors that increased the caloric intake of the African carriers to a standard of 3,639 and 3,201 for rice eaters. ${ }^{138}$

On 26 July, H. Dalziel asked the Macpherson for an assurance that the medical supplies for the sick and wounded in East Africa were adequate. ${ }^{139}$ Macpherson again overreached himself when he replied that, "we know of no shortage of equipment or drugs and can fully meet all

\footnotetext{
${ }^{133}$ Ibid.

${ }^{134}$ Ibid., 1721.

${ }^{135}$ Ibid., 2284.

${ }^{136}$ Great Britain, Parliamentary Debates, Commons, $5^{\text {th }}$ ser., V. 96 (1917), col. 591.

${ }^{137}$ Ibid.

${ }^{138}$ Ibid.

${ }^{139}$ Ibid., 1449.
} 
demands." ${ }^{140}$ On 2 August Molteno asked Macpherson if the rations, he listed on 10 July actually reach the African carriers. ${ }^{141}$ He also wanted to know what additional factors increased their caloric intake. Macpherson replied that the extra rations were 2 ounces of potatoes, plantains or bananas, 2 ounces of Jaggery or goor and 2 ounces of sim sim oil or ghee. In addition, he stated that medical authorities recommended 4 ounces of fresh vegetables every day, an increase in the rice ration to $11 / 4$ pounds. ${ }^{142}$ In addition to the inquiries in parliament, the ASAPS tried to directly petition organs of the British government concerning the Carrier Corps issue, but this proved even less successful.

In August, Harris of the ASAPS wrote to the former S of S, Harcourt asking him for help in inquiring about the high casualty rate for African carriers. According to Harris' figures the casualty rate was 15,000 per month. ${ }^{143}$ Harcourt instructed Harris to get in touch with the governor of Kenya, H. Belfield. Accordingly, Harris wrote Bellfield, who had returned to Britain by this point, on 7 August inquiring about the casualty figures. ${ }^{144}$ Apparently, Belfield contradicted the figures, even though Macpherson had agreed with them, by stating that the high casualties probably only related to a contingent from South Africa. ${ }^{145}$

${ }^{140}$ Ibid.

${ }^{141}$ Ibid., 2292.

${ }^{142}$ Ibid.

${ }^{143}$ J. Harris to L. Harcourt, 3 August 1917, Box G/133, BFASS/APS, Rhodes House Library, Oxford.

${ }^{144}$ J. Harris to H. Belfield, 7 August 1917, Box/G133, BFASS/APS, Rhodes House Library, Oxford.

${ }^{145}$ J. Harris to E. Morel, 12 August 1917, Box/G133, BFASS/APS, Rhodes House Library, Oxford. 
The ASAPS next tried to arrange a meeting between with the War Office and the CO but were rebuffed on both counts. ${ }^{146}$ Consequently, on 24 September 1917 the ASAPS wrote to the Secretary of State, W. Long questioning him about the high death and sickness rate. The society pleaded that "we beg to appeal to the Colonial Office as trustee for the welfare of the native races in British dependencies, to secure a full civil inquiry into the conditions and treatment of these native labour corps." ${ }^{147}$ In October, the ASAPS sent a memorial to the S of S. In the memorial the Society made it clear that even though they were not challenging the ethics of compulsion, they were concerned about the high African death rates of 65 to 80 per 1000 a month and wondered whether the existing system of food supply was adequate. ${ }^{148}$

On 29 May 1918, during a debate in Parliament, the MP H. Molteno asked Ian Macpherson why there was such a high death rate for Africans in the Carrier Corp despite the fact that they were not engaged in the actual fighting. ${ }^{149}$ Molteno went on to disclose that the Africans were dying at a rate of 20 per day with most of these deaths coming from dysentery and pneumonia. ${ }^{150}$ Since the causes of death were all related to treatment, Molteno wondered, rhetorically, if these deaths could be prevented by providing better medical care, clothing and blankets.

${ }^{146}$ Buxton to Molteno, 6 September 1917, Box G/133, BFASS/APS, Rhodes House Library, Oxford.

${ }^{147}$ Buxton to Long, 24 September 1914, Box G/133, BFASS/APS, Rhodes House Library, Oxford. Oxford.

${ }^{148}$ Buxton to Long, 19 October 1917, Box G/133, BFSAS/APS, Rhodes House library,

${ }^{149}$ Great Britain, Parliamentary Debates (Commons) $5^{\text {th }}$ ser., vol. 106 (1918), col. 795. ${ }^{150}$ Ibid. 
Macpherson stated that the British Carrier Corps in East Africa was averaging 118 deaths per week. ${ }^{151} 27 \%$ died due to pneumonia, $19 \%$ due to dysentery, $9 \%$ due to Cerebro Spinal Meningitis and $7 \%$ on account of Malaria. Although he could not account for the high death rate for African carriers, he added, however, that everything was adequate in regards to care.

The abuses associated with Carrier Corp recruitment and service in the Carrier Corp, brought condemnation from humanitarians. The episode of forced recruitment was important in another way. The forced recruitment of African labor during the war demonstrated that coercion could be effective and set a precedent for settler demands for African labor upon the colonial state following the war. ${ }^{152}$

The labor controversies and the subsequent Native Labour Commission reflected the ambiguous nature of colonial policy regarding government recruitment of African labor. There was also a larger question reflected in the poverty of the colonial state and the settlers, whether the state was to harness and develop African labor as a profitable venture for industrial capital. The colonial state response was amorphous to some degree and it did not comply with the monolithic, static picture of capitalist intent that a dogmatic reading of modes of production would give us. Under Crewe and under Harcourt the $\mathrm{CO}$ made it clear that it did not approve of government recruitment of labor for private individuals. However, this did not translate into uniform administrative policy in the EAP due to the vagaries of colonial rule. The "man on the spot" or the colonial official was in charge and, as we saw with Belfield, sometimes his decisions became the colonial policy for that area. This trend would continue after the war and would play

\footnotetext{
${ }^{151}$ Ibid., 796.

${ }^{152}$ Maxon, Struggle for Kenya, 146.
}

Page -158- 
a factor in the 1919-20 labor controversy. WWI delayed the brewing controversy over forced labor but also began some trends that would again carry over into the Northey Crises. The massive conscription of African men for the Carrier Corps coupled with abuses set a disturbing trend of compulsion of African labor that would continue after the war. As always, the ASAPS carried on its historic campaign against bonded labor utilizing the same techniques of moral suasion. After the Native Labour Commission, the ASAPS would soon find themselves again in a familiar role promoting free labor through their denunciation of forced labor as slavery in colonial Kenya in 1920. 
Chapter 6

\section{The Northey Labour Crises: A Symptomatic Reading}

\section{Preamble to A Crises:}

The out break of war precluded the development of a fissure in colonial labor policy . However, the problematic of African labor arose immediately after the war in 1918-1919 and culminated with the release of a labor circular from Governor Northey. The circular was released due to a shortage of labor occasioned by the war. Forced labor recruitment during the war, an out break of disease and famine following the war produced a dearth in African labor recruits. Although proved contentious, in issuing it, Northey was actually following a earlier precedent set by himself and other administration officials before him.

For example, historically, there were extreme variations in labor recruitment at the district level . During WWI the state recruited labor outright. At Fort. Hall district, local District Commissioner Lawford allowed recruitment for private employers, through the chiefs and headmen, in 1917 and 1918. However, the DC that replaced him, L.T. Field Jones, stopped this practice when he took over the following year. ${ }^{1}$

The litany of various administrative circulars regarding African labor recruitment also reflected the ambiguity on the ground. For example, as early as 1907 , the administration had been pressed into action on the labor issue and African recruitment. The state issued a circular on 8 July in response to labor recruitment abuses. After the circular was issued, abuses came up

\section{${ }^{1}$ Robert Tignor, The Colonial Transformation of Kenya: The Kamba, Kikuyu and} Maasai (Princeton: Princeton University Press, 1976), 165.; Memorandum by John Ainsworth on Native Labour Circular, CO 533/233.

$$
\text { Page -160- }
$$


involving forcible recruitment by African chiefs. As a consequence, the administration issued another circular on 15 March 1909 that expressly forbade chiefs and headmen from using force while recruiting labor. But, the circular also emphasized that it was the duty of the colonial chiefs to induce their men to work but by legitimate means.

Another circular on 17 March 1913 more clearly displayed this ambivalence of administrative policy. In the wake of the Native Labour Commission, governor Belfield issued a circular addressing the difficulties of obtaining labor for government purposes. Although the circular stated that the governor was adverse to pressure being placed upon Africans to labor, it also declared that "in such cases it would be justifiable to inform the chiefs of the requirements of government and warn them that they must be met."

Following Belfield's official support of "encouragement," reflected in the Native Labour Commission report, a government issued a circular on 16 March 1914 that reaffirmed Belfield's stance by stating that it was the desire of the government to see able bodied young men go out into the labor field. The circular actually stated that Africans should supply a much larger and more regular labor force. Belfield stated that, "it cannot be too widely known that it is the declared policy of the government to give the fullest encouragement to settlers and natives alike to arrange for the introduction and maintenance on farms of a supply of labour sufficient to meet the varying requirements of different proprietors."

Following WWI, colonial policy regarding forced labor continued on this vacillating path. On 18 September 1918 the Chief Native Commissioner, John Ainsworth, held a meeting at

2“Labour for Government Requirements,” Circular No. 32, 17 March 1913, CO 533/233.

${ }^{3}$ Quoted in Elspeth Huxley, White Man's Country: Lord Delamere and The Making of Kenya, (London: Macmillan and Company Limited, 1935), 61-62. 
Kisumu involving the chiefs of Kisumu, North and South Kavirondo, their headmen, the PC and DC of Kavirondo, representatives of the British East Africa Corporation and British East Africa Sisal and Industrial Company, the Magadi Company, the East African Standard, a missionary, Archdeacon W. Owen, and several other Europeans. The purpose of the meeting was to address labor recruitment problems that had resulted from an earlier baraza or meeting Ainsworth convened on 4 June inquiring into recruiting abuses committed by chiefs. ${ }^{4}$ According to Ainsworth, the June $4^{\text {th }}$ meeting was necessitated by evidence that chiefs had been using force to recruit labor for the British East Africa and Industrial Company. Consequently, at the meeting, Ainsworth informed the chiefs that they could not use force to recruit labor. He added a caveat to his instructions, however, by stating that the “. . government was most anxious that their yong men should go out to work. .." and that they should continue to follow their pre-war instructions to prevent idleness in the reserves by insisting that able bodied men maintain employment. ${ }^{5}$ Ainsworth was clear that employment meant that African men should "go out into the labour fields and earn money."

Perhaps reflective of his ambiguous instructions, Ainsworth held another meeting on 18 September to address reports that European recruiters were informing African chiefs that it was their duty to recruit labor for them. Ainsworth also felt the chiefs were confused by their war time instructions which guided them to recruit labor for employers. As a result, Ainsworth's instructions at the 18 September meeting were carefully worded. Regarding chiefs recruiting for $533 / 273$.

4"Memorandum Regarding a Meeting on the Labour Question," 18 September 1918, CO ${ }^{5}$ Ibid.

${ }^{6}$ Ibid. 
private employers, he stated that:

there is no intention to suggest that the chiefs should be allowed to use physical force ... recruitment of labour forms no part of a chief's duty except in so far as he should be ordered to procure men for urgent government requirements. In my view it would be impossible to allow chiefs to recruit labour for private persons. ${ }^{7}$

However, Ainsworth added that, "at the same time, it must be understood that all Native Authorities were and are under the most definite instructions to do every thing possible to induce their able bodied males to go out into the labour fields."

A scant ten months before Northey promulgated his labor circular, another circular was issued on 13 January 1919 to all Provincial Commissioners and Heads of Departments concerning the recruitment of African labor. This circular was passed after Acting Governor Bowring's repeated attempts to enact forced labor legislation were rebuffed by the $\mathrm{CO} .{ }^{9}$ The new circular cancelled all previous circulars dealing with labor recruitment for government departments and then seriously proscribed the ability of administrative officials to garner labor through the chiefs. The circular stated that provincial and district authorities could not issue letters of introduction to the chiefs for prospective employers and could only act as information houses for labor recruitment.

The vociferous outcry from provincial and district officials produced an amending circular, "Native Labour for Government Requirements," on 24 February signed by the Chief Native Commissioner, John Ainsworth. The new circular stated that labor could be obtained if

${ }^{7}$ Ibid.

${ }^{8}$ Ibid.

${ }^{9}$ Maxon, Struggle for Kenya, 146-47.

Page -163- 
administrative officials held plenty of barazas with colonial chiefs. In these meetings, the chiefs were to be informed that it is the duty of the African population to supply labor for the government. The circular also subjoined that the chiefs "should be reminded that unless and until the labour supply becomes more automatic, there will always exist the necessity of worrying them on the subject." ${ }^{10}$ With reference to government recruitment of labor for state purposes, the circular concluded that,

under any circumstances the efficient conduct of the local administration is a matter that the local natives must assist in and officers as far as necessary, will be justified in using reasonable pressure as before in this connection. ${ }^{11}$

It is against this background that Northey issued his infamous circular on 23 October 1919. Northey, himself, had a common preconceived notion that Africans were prone to idleness and drink and needed compulsion to work. ${ }^{12}$ Upon assuming office, he had actually allowed district and provincial commissioners to temporarily recruit labor for government purposes. ${ }^{13} \mathrm{He}$ did not ask the $\mathrm{CO}$ for permission, at the time, but simply informed them of his actions. He also did not publish his decision. Colonial Office officials chose not to take action. As a result, Lord Milner, the Secretary of State for the Colonies, was not informed of Northey's actions until later and then conveniently overlooked Northey's actions. If the issue came up in parliament Milner could easily deflect criticism. Northey's mistake, in regard to the infamous labor circulars, was

\footnotetext{
10“Native Labour for Government Requirements," Circular No. 4/1, CO 533/233.

${ }^{11}$ Ibid.

${ }^{12}$ Interview with Sir Edward Northey, 23 April 1920, BFASS/APS, Box G 141, "Correspondence about Forced Labor, Land, Cotton and Trusteeship," Rhodes House Library.

${ }^{13}$ Robert Maxon, John Ainsworth and the Making of Kenya (Washington: University
} Press of America, 1980), 362.

$$
\text { Page -164- }
$$


his decision to publish them in the Government Gazette and later and to not inform the CO of his actions. ${ }^{14}$ Northey's circular was also published in the East African Standard on 1 November 1919 in the form of an open letter to well wishers who had acknowledged his recent injury in a polo game. By this point, Northey was convalescing in Europe and the publication of the circulars in the newspaper was a way of conveying a message to the European settlers that the government was on their side and working to encourage slovenly Africans into wage labor. ${ }^{15}$

As mentioned previously, the circular issued on 23 October 1919 entitled "Native Labour Required for non-Native Farms and Other Undertakings" called for the government to induce men into the labor field. It summoned administrative "officers who are in charge of what is termed labour supplying districts ... induce an augmentation of the supply of labour for the various farms and plantations in the protectorate." In addition to "encouraging" African men to go out into the labor field, the circular also affirmed that, "where farms are situated in the vicinity of a native area, women and children should be encouraged to go out for such labour as they can perform." As a recognition of the capillary nature of colonial rule, the circular also stipulated that "native chiefs and elders" should assist in procuring labor and that District Commissioners should keep a record of chiefs that were not compliant in turning out labor. District Commissioners were to hold barazas or meetings to inform the "native" authorities about labor requirements for specific localities, the nature of the work and the rates of pay. The circular also called for recruitment of labor from neighboring Tanganyika. ${ }^{16}$

\footnotetext{
${ }^{14}$ Ibid, 370.

${ }^{15}$ Maxon, Struggle For Kenya, 150.

${ }^{16}$ Labour Circular No. 1, 23 October 1919
} 
Following the release of the circular, supportive criticism came from the missionary sector in the EAP. The two Anglican bishops of East Africa, John Willis of Uganda and R. S. Heywood of Mombasa, and J. W. Arthur of the Church of Scotland issued a memorandum criticizing the circular on 8 November 1918. ${ }^{17}$ Their statement was published in the East African Standard, after consultation with the Chief Native Commissioner John Ainsworth. In their memorandum the Bishops criticized Northey's circular on three fronts. First of all, according to the Bishop's, the circular implied the compulsion of African labor through the ambiguous wording of "encouragement." They added that compulsion was merely slavery and "to the native mind a hint and an order on the part of the government indistinguishable." ${ }^{18}$ For the bishops, then, encouraging African labor was tantamount to compulsion since native chiefs would never understand the subtleties of a "encouragement" and would be prone to abuse their power. The second point of criticism of the circular was that its stipulation that women and children should be encouraged to go out and labor. The Bishops were concerned that encouragement be only applicable to able bodied men. As a last point of criticism, the bishops criticized the circular for implying that Africans were habitually indolent. The Bishops denied this pointing out that Africans had many duties to perform during the course of the year that were, perhaps, not as apparent as wage labor.

Despite the criticism, the Bishops concluded that some form of compulsion was necessary for government and even employers for state work as long as the compulsion was legalized. As they

${ }^{17}$ Clayton and Savage, Government and Labour in Kenya, 113. The bishops issued the statement after consultation and agreement with Ainsworth and the Acting Governor of Kenya Sir Charles Bowring. It was hardly a radical critique.

${ }^{18}$ Great Britain, Despatch to the Governor of the East African Protectorate Relating to Native Labour, and Papers Connected Therewith, Cmd. 873, (July 1920). 
stated, "we recognize that much in this memorandum is good and indeed necessary. Compulsory labor is not in itself an evil and we would favour some form of compulsion ..."19 They admitted they were not attacking the principle of the circular, "the prevention of idleness." They simply advocated a legalized form of compulsion, with clear necessity, that fell upon able bodied men, was practiced uniformly and maintained, defined and limited terms of employment.

Eventually the bishops' statement became known as the "Bishops' Memorandum" and would become problematic in its own right. The significance of the Bishop's Memorandum was that it brought the subject of forced labor to the forefront of public opinion and enunciated many of the themes that would surface in the controversy over the labor circualr. As Lord Olivier stated:

To many in this country it was a new and startling discovery that forced labor, including unpaid forced labour was an institution prevalent in the British Empire. The notion was quite incompatible with the principle established in the second period of colonial policy and traditionally supposed to be still observed. ${ }^{20}$

Amid the growing controversy, the administration passed an amendment to the 1912 Native Authority Ordinance that received little fanfare, initially. The amendment to the 1912 Native Authority Ordinance in 1920, section 8 (o) of the Ordinance, provided paid forced labor for state purposes for periods of up to sixty days per year for the construction and maintenance of railways and roads, bridges, porterage, waterworks, government buildings, harbor works and telegraph and telephone systems within the colony. Section 8 (n) provided for the coercion of labor for porterage and section $8(\mathrm{~m})$ provided for coercion in case of emergency of unforseen

${ }^{19}$ Ibid. 242.

${ }^{20}$ Lord Olivier, White Capital and Coloured Labour (London: Hogarth Press, 1929), 
damage to roads, railways or government buildings. There were labor exemptions to the 1920 amendment. Africans who had previously labored already for 60 days in the year were exempt as were Africans who had already been employed for a period of 3 months within the year for European employers. African men could also gain exemption if they were headmen or members of councils, clergy, teachers appointed by DC's, hospital dressers appointed by principal medical officers, camp caretakers, and Africans approved by the DC's who were engaged in trade, business or agriculture on their own accord.

The ulterior purpose of the labor requirements under the section 8(h) and 8(o) was to push African labor to European employers. Essentially, it was state recruitment for private purposes. The exemption clauses in the 1920 amendment allowed workers to be exempt if they had been employed by European employers for at least three months during the past twelve months. Although the law did not state, specifically, that Africans had to be employed for wages, it was implied and accepted. There were no exemptions for individual work on their own plots. As Acting Chief Native Commissioner O. F. Watkins stated "it would not be possible to accept the natives own statement that he had done three months work and that the difficulty of finding a sufficiently reliable witness to prove that he had done it would be almost insuperable."21

Back in London, by February, the CO still did not have a copy of the circular; however, agitation against the circular commenced in the House of Commons in 1920. On 25 February the Liberal MP Lord Henry Cavendish-Bentinck ${ }^{22}$ asked the Under Secretary of State for the Colonies, Lieutenant Colonel Leopold Amery, whether he was familiar with the Bishop's critique

${ }^{21}$ O. F. Watkins to Archdeacon Owen, 29 March 1921, Box G/141, BFASS/APS, Rhodes House Library, Oxford.

${ }^{22}$ Cavendish Bentinck was also chairman of the General Committee of the ASAPS. Page -168- 
of Northey's circular and, if so, what action would be taken in regards to this matter. ${ }^{23}$ Specifically, Bentinck wanted to know whether the circular instructed administrative officials to encourage African labor for individuals; whether the circular was submitted to the $\mathrm{CO}$ before being issued and, if not, whether the offending circular would be withdrawn. ${ }^{24}$

Amery diplomatically stated that he had only recently received a copy of the circular and as such was not ready to make a statement regarding it. ${ }^{25}$ Concerning the Bishop's Memorandum, Amery adroitly noted that the Bishop's critique was directed mainly against abuses of power by African chiefs and headmen as opposed to the principle of compulsion with safeguards.

Cavendish-Bentinck pressed on. He queried Amery whether Northey's Circular was a departure from precedent. ${ }^{26}$ Amery responded that "no illegitimate pressure should be put on native chiefs which would cause them practically to force the natives to labour for private employers, but I should have thought it was quite in the interests of the natives ... that they can labour for private employers" as long as force was not applied. ${ }^{27}$ At this point, the Liberal MP J. Wedgwood chimed in and asked Amery if he was not aware that the circular in question did bring pressure. $^{28}$

During this period, $\mathrm{CO}$ was assured by Northey that the labor policy reflected in the circular 1689.

${ }^{23}$ Great Britain, Parliamentary Debates, Commons, $5^{\text {th }}$ ser., vol. 125 (1920), cols. 1688-

${ }^{24}$ Ibid.

${ }^{25}$ Ibid.

${ }^{26}$ Ibid.

${ }^{27}$ Ibid.

${ }^{28}$ Ibid. 
was working fine in the Colony and Protectorate and that there was no indication of any

dissatisfaction on the part of the Africans. ${ }^{29}$ On the contrary, Northey stated, since the government was not using force to recruit labor, any problems in that regard could be attributed to African chiefs.

On 26 February in the House of Commons the Labour MP, Colonel J. Wedgwood picked up the debate over the Northey Circular again. ${ }^{30}$ Wedgwood repeated Bentinck's query and asked Amery wether he was familiar with the Bishop's Memorandum. And, with a bit of calumny, he asked Amery whether the government was committed to allowing African labor to be forcibly recruited by "native chiefs" under the stimulus of British officials. ${ }^{31}$

In response, Amery initially referred Wedgwood to his answer to Bentinck on the previous day. However, Wedgwood pressed on and asked to actually view the circular. At this point Amery admitted that he had not seen an "official" copy of the circular but was waiting for a response from the governor of Kenya. ${ }^{32}$

The controversy surrounding the Northey circular continued on 18 March in the House of

${ }^{29}$ Minute by A.C.C. Parkinson, 8 March 1920, 533/242.

${ }^{30} \mathrm{~J}$. Wedgwood was a liberal MP, who later switched to the Labour party by 1920. Although as a Liberal he was a staunch proponent of empire, he championed the causes of colonial wards and was involved in the international condemnation of Belgian atrocities in the Congo among his many pursuits of aboriginal rights. Besides African concerns, Wedgwood was also engrossed in Indian affairs and had hoped to become secretary of State for India. As a member of the Labour party he was one of the main critics of British colonial policy. Robert Gregory, Sydney Webb and East Africa: Labour's Experiment with the Doctrine of Native Paramountcy (Berkeley and Los Angeles: University of California, 1962), 88.

${ }^{31}$ Great Britain, Parliamentary Debates, Commons, $5^{\text {th }}$ ser., vol. 125(1920), cols. 189091.

\footnotetext{
${ }^{32}$ Ibid.,
} 
Commons. The MP, B. Spoor, asked Amery whether the government in Kenya put the onus for recruiting on the African chiefs and headmen and, if so, what was the legal sanction behind these instructions. ${ }^{33}$ Spoor also asked Amery about the punitive action administration officials took against African chiefs who do not conform. Again, Amery reiterated that the issue would be discussed with Northey and the S of $\mathrm{S}$ at a latter date. He also was forced to belatedly admit, under questioning from Wedgwood, that he did not yet have a copy of the circular. ${ }^{34}$ By April, the CO still did not have an official copy of the circular. This prompted an exasperated Wedgwood to ask Amery on 21 April, "how much longer shall we have to wait for a circular which was asked for months ago." 35

On 26 April on a Supply vote in the House of Commons the discussion turned to the Northey circular when the Labour MP B. Spoor compared the labor policy inferred in the Northy circular to "veiled slavery." ${ }^{36}$ For his part, Amery stated that there was nothing in the circular that implies anything beyond encouragement or advice. ${ }^{37}$ He reminded Spoor that the Bishops Memorandum supported the general terms of the policy and the main anxiety arising from the circulars related to abuse of power by chiefs. Amery also stated that he had an unofficial copy of the circular and that Northey had assured the $\mathrm{CO}$ that compulsion was not the intention of the circular. $^{38}$ He added that an amendment circular was being formulated. On 27 April 1920, the

\footnotetext{
${ }^{33}$ Great Britain, Parliamentary Debates, Commons, $5^{\text {th }}$ ser., vol. 126 (1920), 2392.

${ }^{34}$ Ibid., 2393.

${ }^{35}$ Great Britain, Parliamentary Debates, Commons, $5^{\text {th }}$ Ser., vol. 128 (1920), col. 398.

${ }^{36}$ Ibid., 931.

${ }^{37}$ Ibid., 953-54.

${ }^{38}$ Ibid., 955.
} 
MP Robert Young continued the attack on the labor circular in the House of Commons asking whether the Northey circular repudiated Crewe's despatch of 1908 and whether he was aware of the Bishop's memorandum. ${ }^{39}$ This time Amery referred the MP to his statements the previous day on this very issue. ${ }^{40}$

As mentioned previously, the Bishop's Memorandum was problematic and had elicited criticism against its ambivalent stance on forced labor from other humanitarian groups. This merely compounded the burgeoning Northey crisis. An editorial critical of the Northey Circular appeared in the New Statesman on 10 April 1920. It stated that the circulars violated the principle of British rule in Africa. ${ }^{41}$ Moreover, the editorial equated forced labor with slavery and deemed it morally indefensible. More significantly, however, the editorial went on to contest certain cultural assumptions associated with Africans which were implied in the Bishop's Memorandum. The editorial writer stated that Africans would work, without compulsion, under free labor, if given land. Another letter to the editor from an unknown writer named Salim echoed the sentiments of the previous editorial regarding trusteeship and the Africans. He also added that the picture of idle Africans so prevalent in European minds did not take into account the work done by African woman in agriculture. ${ }^{42}$ The image of the Idle African would remain a

${ }^{39}$ Ibid., 1064.

${ }^{40}$ Ibid.

${ }^{41}$ Editorial, New Statesman, 10 April 1920, International Missionary Council and Conference of British Missionary Societies Joint Archive, Box 238, File: Government Schemes, "Lord Milner's Despatches," SOAS, London.

42،"East Africa from Salim,” News Statesman, 10 April 1920, International Missionary Council and conference of British Missionary Societies Joint Archive, Box 238, File: Government Schemes, "Lord Milner's Despatches," SOAS, London. 
resonant but convenient theme for Europeans. ${ }^{43}$

Humanitarian opposition in Great Britain began to mount against the circulars early in 1920 as the controversy spread beyond the missionary sector. In the New Statesman, in September, an editorial criticized the Bishop's position that some form of compulsion was necessary. ${ }^{44}$ Norman Leys complained to John Oldham that the Bishop's Memorandum was "unchristian." ${ }^{45}$ Frank Weston, the Bishop of Zanzibar, called the signatories of the Bishops Memorandum "traitors." ${ }^{46}$ He would later write a letter to J. H. Oldham, who was marshaling a campaign against the circulars, giving him evidence, from the field from District Commissioners who condemned Northey's labor circular. ${ }^{47}$

Oldham, for his part, tried to get the Bishop of Uganda, John Willis, to tone down his statements. Willis, however, steadfastly maintained that force was necessary and refused. ${ }^{48}$ In a

${ }^{43}$ Evidence for the Kavirondo Tax payers Association for the Commission on Closer Union in 1927 also contradicted this image of the lazy African. The report discussed gender delineation in agricultural work. According to the report, men were responsible for building houses, grain stores, fencing and ukeep of kraals, first break of soils, watching the crops and cattle at night, dressing skins, making tools, planting bananas, sugar cane and tobacco plus building wells. "Report of Kavirondo Association for Commission of closer Union," East African Standard, 31 December 1927.

44،"The New Slave Policy in East Africa," New Statesman, 11 September 1920, International missionary council and Conference of British Missionary Societies Joint Archive, Box 238, File: Government Schemes, "Lord milner's Despatches," School of Oriental and African Studies, London.

${ }^{45}$ Leys to J. H. Oldham, 26 May 1920, IMC/CBMS, Box 248, File: "East Africa Correspondence," SOAS, London.

${ }^{46}$ Maynard Smith, Frank Bishop of Zanzibar (London: 1926),250.

${ }^{47}$ Weston to J. H. Oldham, 10 October 1920, Box 240, File: "Missionaries on the Field," IMC/CBMS, SOAS, London.

${ }^{48}$ Holger Bernt Hansen, "Forced Labour in a Missionary Context," in Michael Twaddle, ed. The Wages of Slavery: From Chattel Slavery to Wage Labour In Africa, The Carribean

Page -173- 
letter to Oldham he reiterated some of the same themes contained in the Bishops memorandum.

Willis restated that compulsory labor was not evil in itself because it prevented "idleness." ${ }^{, 49} \mathrm{He}$ saw nothing wrong with compulsion as long as it was done with safeguards. And, as a stubborn gesture of his dogmatic repose, Willis would later refuse to sign Oldham's memorandum, "Native Labor in East Africa and The Principle of Trusteeship," that was eventually forwarded to the $\mathrm{CO}$ in 1921

The ASAPS initially wrote a letter to the Under Secretary of State for the Colonies on 12 January inquiring about a labor circular issued for "West Africa" under the signature of Colonel Ainsworth. ${ }^{50}$ The Society had been in contact with Sir John Kirk, was vaguely familiar with the labor circular, but was unable to track down a copy of it. ${ }^{51}$ As stated earlier, surprisingly, the CO still did not yet have a copy of Northey's Circular.

On 24 February 1920 the Harris wrote a letter to the reporter Charles Watney of the St. Stevens Intelligence Bureau and East African Standard outlining the position of the Society in regards to labor in East Africa. ${ }^{52}$ The ASAPS stated it was against forced labor for private purposes and stated that taxation of Africans should depend on the ability of the Africans to pay

and England (London and Portland: Frank Cass, 1993), 196.

${ }^{49}$ Willis to J. H. Oldham, 10 May 1920, Box 240, File: "Missionaries on the Field," IMC/CBMS, SOAS, London.

${ }^{50}$ Travers Buxton, to Under Secretary of State for the Colonies, 12 January 1920, CO $533 / 248$.

${ }^{51}$ Harris to Mrs. Hindes, 17 February 1920,Box G/141, "Correspondence, About Forced Labor, Land, Cotton, Trusteeship,” BFASS/APS, Rhodes House Library, Oxford.

${ }^{52}$ ASAPS to Watney, 24 February 1920, Box G/141, "Correspondence, About Forced Labor, Land, Cotton, Trusteeship,” BFASS/APS, Rhodes House Library, Oxford. 
as opposed to whether they were employed by Europeans.

Armed, now, with the labor circular, the ASAPS wrote again to the CO on 5 March 1920 asking for a declaration of the duties of administrative officials in Kenya in regards to "encouragement" of labor. ${ }^{53}$ The Society was concerned that the labor policy of circular implied coercion. This, according to the ASAPS, contradicted an earlier statement in the House of Commons in 1919 by Colonel Amery, the Under-Secretary of State for the Colonies, that the European mission in Africa was to help develop Africans on their individual plots of land. In addition, the Society decried, the fact that, by implication, chiefs would be penalized for not turning out labor. In response to their query, the $\mathrm{CO}$ asked Northey to meet with ASAPS representatives and address their issues of concern relating to the circular.

Northey responded to the points raised by the ASAPS in a letter to the S of S on 26 March 1920. In defense of his labor policy Northey boldly asserted that the real issue reflected in his labor circular was the matter of imperial policy. He stated the obvious. White settlement and the production of raw materials had been encouraged, so it was up to the administration to "bring the native to the labour market and teach him to work ... under good European supervision." ${ }^{.54}$ According to Northey, Africans were by nature prone to idleness and it was up to the administration to induce them to work for their own advancement. He concluded his letter by

\footnotetext{
${ }^{53}$ Travers Buxton to Under Secretary of State for the Colonies, 5 March 1920, CO 533/248. The ASAPS received a copy of the circular in February, through Sir John Kirk, along with a copy of the Bishop's Memorandum. Up till that point the ASAPS had struggled to get information about the circular from the CO, Norman Leys and finally an Informant named Hindes who was an associate of Sir John Kirk. Harris to Mrs. Hindes, 17 February 1920, Box G 141, "Correspondence about Forced Labour, Land, Cotton, Trusteeship," BFASS/APS, Rhodes House Library, Oxford.
}

${ }^{54}$ Northey to Under-Secretary of State for Colonies, 26 March 1920, CO 533/227. 
alluding to the Bishop's Memorandum as proof that African idleness was the main problem and the labor policy implied in the circular offered a solution.

On 23 April 1920 he met with members of the ASAPS and reiterated his themes in support of the circular. ${ }^{55}$ He insisted that the purpose of British colonialism in Kenya was to develop the natural resources of the country. The Africans "had no idea ... of what healthy work and exercise mean" so compulsion for public works was necessary. Regarding the stigmatization of chiefs who were non compliant in producing labor, Northey stated that they were government servants and consequently were liable for non performance of their duties.

After the meeting, Northey complained that the ASAPS was ignorant of affairs in the Kenya Colony, none of the representatives of the ASAPS ever having even been to Africa. He derided the representatives of the society at the meetings as "narrow minded and bigoted" "cranks" who were not even familiar with the various ordinances that governed labor. Northey concluded that they were unable to grasp his position due to their ignorance and would undoubtedly press for the issue of another circular. ${ }^{56}$

After the meeting, Northey met with Milner and officials within the CO to work out a new labor circular. On 3 May Northey wrote the $\mathrm{CO}$ with his own version of an amended circular. ${ }^{57}$ The revised circular No.2, written by Ainsworth on 17 February while Northey was in England, had softened the language of the previous circular but not its intent. It was meant to clear up misinterpretations of the original circular. Ainsworth's new circular alleged that the original

\footnotetext{
${ }^{55}$ Interview with Sir Edward Northey, 23 April 1920, Box G 141, "Correspondence about Forced Labor, Land, Cotton and Trusteeship," BFASS/APS, Rhodes House Library, Oxford.

${ }^{56}$ Northey to Bottomley, 8 May 1920, CO 533/253.

${ }^{57}$ Northey to Bottomley, 3 May 1920, CO 533/253. 
wording in circular, pertaining to instructions to native authorities, had been misconstrued. The phrase in the original circular, "every possible lawful influence," simply meant that chiefs and headmen should remind Africans within their jurisdiction that "it is very desirable for them to go out into the labour field." ${ }^{, 58}$ Moreover, circular No. 2 added that women and children should be allowed to return home at night from labor projects and that chiefs and headmen should ensure that they do not oppress workers under their care. The revised circular emphasized that there was no intent to recruit. But, it still added that it was the duty of native authority to "advise and encourage all unemployed young men under their jurisdiction to seek work on plantations." ${ }^{59}$ It seems clear, also, in Northey's letter that he never seemed to make the connection between the humanitarian agitation and the equation of forced labor and slavery. Alluding to his meeting with the Society, his letter presupposed that ASAPS criticism of his policies was due more to their ignorance than an essential fault within. In the letter he simply restated that colonial chiefs would not abuse their power to turn out labor. Again, Northey missed the point and emphasized that the object was to make the Africans work. Besides the surprise at receiving the circular so late, the feeling within the $\mathrm{CO}$ was that circular No. 2 could be read to support indirect coercion of labor. ${ }^{60}$ In addition, a new circular, No. 3, was being formulated at the time. Consequently, circular No. 2 was seen as a bit redundant and was eventually cancelled.

By this time, Milner was much more sensitive to the pressure from various interests in the humanitarian lobby and parliament and was searching for a new statement on the labor circulars

${ }^{58}$ Circular No. 2, 17 February 1920, CO 533/234.

${ }^{59}$ W. MacGregor Ross, Kenya From Within, (London: Frank Cass, 1968), 107.

${ }^{60}$ Minute by A.C.C. Parkinson, 17 July 1920, CO 533/234.

Page -177- 
that would assuage the critics. In reading Northey's letter from 3 May, he felt it necessary to refocus some of the points Northey was glossing over. Milner felt that an amendment circular should include provisions that women and children would not stay overnight while working. Also, Milner stated that care must be taken that African chiefs not abuse their power. He wrote Northey with a reference circular of the original labor circular emphasizing these points on 25 May. $^{61}$

The circular, written actually by W. Bottomley in the CO, emphasized certain points which were intended to ameliorate the caustic apprehension with the original labor circular. While Milner agreed with the principle of the original labor circular that it was in the interests of Africans to come out of the reserves as wage earners, he noted that care should also be taken to make sure "native" authorities did not abuse their power in the recruitment of African labor. The second point made in the circular was that women and children should be allowed to return home at night after laboring. Only when the husband was also laboring on a farm should the women or children be allowed to remain at the work site overnight. ${ }^{62}$ This was a rehabilitation of one aspect of the original circular that called for women and children to be encouraged to work on private farms if they were close by.

Indicative of his inability to gage the winds of change, Northey responded to Milner on 26 May with concerns about the wording of Milner's reference circular. ${ }^{63}$ Particularly, Northey was concerned that Milner's reference to women working away from the home overnight might retard

\footnotetext{
${ }^{61}$ Milner to Northey, 25 May 1920, CO 533/253.

${ }^{62}$ Ibid.

${ }^{63}$ Northey to Milner, 26 May 1920, CO 533/253.
} 
the supply of labor to coffee plantations that employed squatters. This suggestion was accepted and the eventual circular, "Native Labour Required for Non Native Farms and other private Undertakings," was published on 14 July after Northey's return to Kenya.

Humanitarian criticism did not abate despite the publication of the amending circular. Following Northey's blunt meeting with members of the ASAPS, Harris wrote to the bishop of Mombasa that the he was "deeply concerned about the intentions of the governor." ${ }^{44}$ Harris was particularly bothered by the governor's prophetic statement that he would stand and fall by the policy of his circular. Consequently, Harris and Lord Islington ${ }^{65}$ began to push for a parliamentary debate on the labor problem in Kenya.

In June 1920 the ASAPS published a memorial by the Earl of Cromer (1841-1917), originally written in 1908. Cromer had been member of the ASAPS and, as agent and proconsul to Egypt from 1883 to 1907 , had served as its virtual ruler. The publication of his memorial was, in essence, a policy statement defining forced labor for private purposes as slavery. Cromer's memorial, "What is Slavery," discussed the legality of forced labor. ${ }^{66}$ The context of the memorial was British use of forced labor in Egypt and in dependent colonies in general. According to Cromer, forced labor was practical and justifiable in certain contexts like for use on public projects. As he stated,

we reluctantly admit the necessity of compulsory labor in certain cases and that

${ }^{64}$ Harris to Bishop of Mombasa, 16 June 1920, Box G 141, BFASS/APS, Rhodes House Library, Oxford. Office.

${ }^{65}$ Islington had previously served as Under Secretary of State in 1914 and in the India

${ }^{66}$ Earl of Cromer, "What is Slavery," (London: Anti-Slavery and Aborigines Protection Society, 1920).

Page -179- 
we do not stigmatize as slavery such labour when, under all possible safeguards against the occurrence of abuses, it is employed for recognized and indispensable purpose of public utility. ${ }^{67}$

He gave examples of statutes in Britain governing the construction of roads and in France of the corvée where forced labor had been used and was justifiable. However, when forced labor was used for private profit it was synonymous with slavery and, therefore, was not justifiable. As he stated, "on the other hand we regard the system when employed for private profit as wholly unjustifiable and synonymous with slavery."68 The importance of this document for the ASAPS and also John Oldham, when he later joined the controversy, was that it served as proof that the labor strategy inferred in the Northey circular, state recruitment for industrial purposes, represented a break with past imperial policy regarding the trust principle. As Harris stated in 1921,

I have endeavoured to show that the policy in East Africa is a complete break with Colonial Policy as laid down by our Victorian statesmen, like Lords Cromer and Derby, in that we have in fact declared an imperial "property right" in the labour of Africans. ${ }^{69}$

In June Harris also began to contact several important statesmen and religious figures to garner support for the debate in the House of Lords. Harris hoped that a debate over the labor policy of the Northey circular in the House of Lords would push Milner or perhaps embarrass the

${ }^{67}$ Ibid.

${ }^{68}$ Ibid.

${ }^{69}$ Harris to Charles Watney,12 July 1921, Box G 141, "Correspondence about Forced Labor, Land, Cotton and Trusteeship,” BFASS/APS, Rhodes House Library, Oxford. Watney served as a reporter for the EAS and was actually not in favor of the campaign against the Northey circular. He repudiated the campaign in a private letter to Northey on 20 February 1920. Charles Watney to Northey, 20 February 1920, CO 533/227.

$$
\text { Page -180- }
$$


$\mathrm{S}$ of $\mathrm{S}$ into convening a royal commission of inquiry into the affair. ${ }^{70}$ With the aid of Lord Islington, ${ }^{71}$ Harris was able to get the support of several other statesmen in the house of lords, mainly Lords Emmot, Bryce and Mayo and Buckmaster, to support, as he put it, "a first class debate" on the labor problem in Kenya. Harris also received the support of several missionary groups, including the Society for the Propagation of the Gospel and also received the support of the Archbishop of Canterbury, Randall Davidson. Islington's plan in the House of Lords was to call for a debate to discuss the lack of coordination between the India government and the $\mathrm{CO}$ in regards to their "obligations." 72 Northey's circular with the future of British policy in East Africa would be piggy backed on this issue. The initial debate was called for 30 June 1920 . However, Milner called for a postponement until 14 July. In the meanwhile, Harris prepared his allies for the debate by sending them copies of Ainsworth's circular, a letter from J. H. Oldham of the conference of Missionary Societies to the CO, the Bishop's memorandum and another letter from Harris to the $\mathrm{CO} .^{73}$

In the lag before the debate, the ASAPS sent Milner another letter on 17 June $1920 .{ }^{74}$ In the letter, the Society summarized their main arguments against the Northey circular. With reference to the Earl of Cromer, the Society restated its opposition to forced labor for private purposes but

\footnotetext{
${ }^{70}$ Harris to Islington, 15 July 1920, Box G 141, "Forced Labour East Africa, Land," BFASS/APS, Rhodes House Library, Oxford.

${ }^{71}$ Chairman of the India Commission.

${ }^{72}$ Harris to Islington, 15 July 1920, Box G 141, "Correspondence about Forced Labor, Land, Cotton and Trusteeship," BFASS/APS, Rhodes House Library, Oxford.

${ }^{73}$ Harris to Lord BuckMaster, 9 July 1920; Harris to Lord Mayo, 9 July 1920; Harris to Cantaur, 2 July 1920, Box G 141, "Correspondence about Forced Labor, Land, Cotton and Trusteeship,” BFASS/APS, Rhodes House Library, Oxford.

${ }^{74}$ Travers Buxton to Viscount Milner, 17 June 1920, CO 533/248.
} 
reluctantly accepted forced labor for public utility, provided there were safeguards. As they stated,

we reluctantly admit the necessity of compulsory labor in certain cases and we do not stigmatize as slavery such labor ... employed for indispensable and recognised purposes of public utility. ${ }^{75}$

In addition, the Society pointed out that Lugard, in his book the Dual Mandate, condemned forced labor even in the building of roads and railroads. In reference to Northey's amendment to the 1912 Native Authority in 1920, the ASAPS regarded the exemptions that could free one form public labor as also including the time spent by African's on their individual plots of land. They also added that a 1909 Whitebook on forced labor called for its use for up to 30 days a year as opposed to the 60 days in the 1920 amendment of the Native Authority Ordinance. The letter closed with a list of possible safeguards to ameliorate forced labor. These included the fantastic notion of instituting a corvee without reference to race, allowing Africans to commute their corvee sentence through taxation and stopping the system of allowing people to labor far from home. $^{76}$

The CO responded that Milner was still waiting for Northey to send him the amended circular of his original. The minute by one of the Colonial Office officials, Cecil Bottomley, stated that the amendment to the Native Authority Ordinance had gone a long way to meeting most of the demands of Bishop's memorandum anyway. ${ }^{77}$ While the CO grappled with affairs in London, events within Kenya shed further light on some of the problems of the labor circular and forced

${ }^{75}$ ASAPS to Milner, 17 June 1920, Box 238, East Africa: Kenya Native Labour, File: Government Schemes, IMC/CBMS, SOAS, London.

${ }^{76}$ Ibid.

${ }^{77}$ Minute by W. C. Bottomley, 21 June 1920, CO 533/248. 
labor policy in the colony.

\section{Within The Colony and Protectorate}

The Northey Crisis laid bare the contradictions of the colonial state. The fallacious monolithic vision of "state" lay in tatters. Within Kenya, the state moved to counter the criticism of the circulars while missionary groups machinated in their role as the African voice.

Administrative officials within Kenya responded to the Northey circular with varying degrees of acceptance. For example, A. Wade, a District Commissioner for Kiambu, wrote that he had explained the labor circular to chiefs and headmen through various barazas. ${ }^{78}$ He told them that no force was to be used, but he emphasized to the chiefs that no one should remain idle. Wade, also, issued a direct order to the headmen and chiefs that anyone refusing to work should be brought to him for an interview. Wade, also, took it upon himself to inform the African population in his district that European planters crucially needed labor for coffee picking. Outside of complaints about girls being forced to work overnight, Wade stated that he "received no complaints or oppositions of any kind from the natives."79

In the wake, or perhaps spirit, of the circular the DC of Fort Hall district, A. Jones, was instructed by the Provincial Commissioner to "give every assistance" to a labor recruiter named Pridemore to engage Africans in labor who had not paid their taxes for the current year. ${ }^{80}$

${ }^{78}$ A. Wade to Provincial Commissioner's Office, Nairobi, 29 January 1920, Papers of Elspeth Huxley, Box 1/3, Rhodes House Library, Oxford.

${ }^{79}$ Ibid.

${ }^{80}$ A Field Jones to J. A. G. Elliot, 10 March 1920, Papers of Elspeth Huxley, Box 1/3. Rhodes House Library, Oxford. 
Another example illustrates the climate of recruitment that the labor circular created in Kenya.

On one occasion the District Commissioner of Fort Hall denied the request of the Coffee Planters Union of the Thika District Association to recruit labor in Meru and Embu districts. Jones stated that the areas under question were already being heavily recruited by local parties and could not sustain anymore poaching. The response from the Thika District Association was emblematic. In a resolution, they condemned Jone's actions and stated that his denial of their request was "against both the spirit and the letter of Sir Edward Northey's late circular." their complaints against Jones to Northey, himself. In the telegram to Northey, the Association complained that no efforts were being made to carry out the labor circular. In response to these accusations, Jones pointed out that it was not his duty to recruit labor for private citizens. He did, however, add that "chiefs and headmen have standing instructions to see that no able bodied men remain loafing in their locations." ${ }^{" 82}$

Contrary to Northey's earlier statements to the $\mathrm{CO}$, all was not quiet within the Colony and Protectorate. Some administrative officials did not agree with the policy inferred in the Northey labor circular. In late November 1919, J. A. G. Elliot, a DC for Embu district in Kenya, called on the Colonial Office in London while on leave to complain about the labor policy in Kenya. ${ }^{83}$

Elliot made it clear that he was strongly opposed to the labor policy inferred in the Northey labor circular. He disputed the circular's inference that most Africans were lazy and idle in the

\footnotetext{
${ }^{81}$ S. L. Lawford to Chief Native Commissioner, 29 March 1920, Papers of Elspeth Huxley, Box 1/3, Rhodes House Library, Oxford.

${ }^{82}$ A. Jones to Provincial Commissioner Tate, 3 April 1920, Papers of Elspeth Huxley, Box 1/3, Rhodes House Library, Oxford.

${ }^{83}$ Minute by W. Bottomley, 1 December 1920, CO 533/247. 
reserves. Elliot stated that their was a division of labor for most Africans. Men were responsible for breaking the ground for tilling, clearing bush and stumping while women did the subsequent planting of crops. His main concern was that increased emphasis on turning out African labor out for government projects and for private individuals would take time away from African cultivation.

For this reason, Elliot was against government forced labor for state projects with the exception of communal labor. Communal labor, according to Elliot, was acceptable because it was to the benefit of the community involved and he found it to be quite useful for road making in his district. Elliot was also critical of government recruitment of labor for private interests due to the negative impact on African cultivation, but he, also, felt that it placed disproportionate burden on the poor. When a call for labor came up, headmen frequently chose the poor to go out of the reserves and labor. Elliot concluded his remarks by stating that no administrative official who could afford to resign is carrying out the labor policy of the circular. He refused, however, to put his complaints in writing for fear of disciplinary action. ${ }^{84}$

The CO regarded Elliot's "experience of native conditions not to be compared with that of Ainsworth who has shown no sign of misgivings." 85 However, they did warrant his criticisms to be specific enough for further investigation. And, as Robert Maxon has written, after Elliot's testimony the $\mathrm{CO}$ began to regard Northey's assertions with more skepticism. ${ }^{86}$ Consequently,

\footnotetext{
${ }^{84}$ Minute By W. Bottomley, 1 December 1920, CO 533/247.
}

${ }^{85}$ Ibid.

${ }^{86}$ Robert Maxon regards Elliots testimony coupled with Ainsworths later statements as the pivotal events that convinced the $\mathrm{CO}$ to change policy regarding force labor. Robert Maxon, Struggle for Kenya, 156. 
Northey was asked to submit a report on 3 December as to the workings of the labor circular in Kenya.

Northey responded on 11 December 1920. His statements to the CO regarding the working of the labor circular within Kenya were quite positive. ${ }^{87}$ Due to the recent application of the Resident Native Ordinance of 1918 that controlled African squatting on European land, Northey stated that Africans were being drawn into the labor market and the present labor situation was quite good. Government was using forced labor on a limited basis and then mainly applied to the young. According to Northey, headmen were not abusing their powers and the participation in wage labor was not affecting African cultivation since it was "contrary to native custom for families to accompany males on short contracts" anyway ${ }^{88}$ Without specific evidence contradicting Northey's assertions, his response satisfied the $\mathrm{CO} .{ }^{89}$

H. R. Tate, the Provincial Commissioner in Nyeri, also, disagreed with some of the implications of the labor circular, also. In a memorandum on the Northey circular he complained that the circular essentially forced administrative officials to act as recruiters for private employers but without the sanction of law. ${ }^{90}$ As a remedy, he called instead for the logical conclusion of the Northey circular, an ordinance to legalize compulsion by government officials. Tate was concerned that without legal sanction the DC or PC was fulfilling contradictory roles as recruiter for private individuals, on one hand, and as a magistrate for Africans on the other.

${ }^{87}$ Northey to Secretary of State for the Colonies, 11 December, 1920, CO 533/238.

${ }^{88}$ Ibid.

${ }^{89}$ Minute by W. Bottomley, 13 December 1920, CO 533/238.

${ }^{90}$ H.R. Tate to Chief Native Commissioner, 27 December 1919, Papers of Elspeth Huxley, Box 1/3, Rhodes House Library, Oxford. 
Many DCs had to navigate between the polarities of settler aggrandizement and African amelioration. An anonymous editorial to the East African Standard signed by "Ex-Official" amplified Tate's point. According to this anonymous writer, DCs that did not recruit for Europeans were labeled "pro native" while DCs that did were seen as friendly to the settlers. The middle ground appeared to be transitory.

Northey's response to Tate's criticism revealed the true intent of his circular. He reiterated that government recruitment did not "mean the use of unlawful methods, such as force under threat of punishment." ${ }^{92}$ But, he added, if administrative officers did not act as agents it would render the intention of the circular liable to misinterpretation. Northey made it clear that "the civil official who is ordered to give all possible lawful assistance must act as an agent. ${ }^{" 93}$ His statements were sent to all Provincial Commissioners.

Ainworth's response to Tate's memorandum was quite a departure from Northey's. In addition, examined with his other memorandums on the subjects, it disclosed the contradictory sentiments of an administrative official wedded to African development. Ainsworth decried Tate's conclusion that the logical development of Northey's circular within the colony should ultimately lead to legalized state coercion. Ainsworth did not think that legalized state compulsion for private individuals could be approved anyway. However, In contrast to Northey, he stated concretely that "I would add that I am definitely opposed to any form of recruitment by

91“Native Labour: Compulsion V. Alleged Camouflage," East African Standard, 8 November 1919.

${ }^{92}$ Northey to Chief Native Commissioner, 1 November 1919, Papers of Elspeth Huxley, Box 1/3, Rhodes House Library, Oxford.

${ }^{93}$ Ibid. 
the State for private undertakings."94

It is, perhaps, a historical irony that John Ainsworth's name was affixed to the original labor circular that caused so much furor. Ainsworth had always been considered an overly "pro native" administrative official during his tenure as PC of Nyanza by most of the settler element. During the 1912-13 Labour Commission, Lord Delamere opined that Ainsworth was the cause of some the labor problems within the protectorate through his promotion of African production during his tenure as PC of Nyanza. When Ainsworth was appointed Chief Native Commissioner in 1919, one of the leading settlers, Ewart Grogan, actually made a speech condemning his selection. Ainsworth's belief in the separate but equal African development lay at the core of this historical conundrum.

Memorandums Ainsworth submitted to the CO in August 1913 concerning general education for Africans and development in Nyanza Province provide an elucidation of his views. Ainsworth's views on development in Nyanza explicated his support for African development and shed light on his ultimate association with the Northey Circular.

In his statements, Ainsworth definitely was in favor of African development as a means of ameliorating the condition of Britain's colonial wards under the rubric of trusteeship. As he stated:

what we require in East Africa is a general policy for the uplifting and betterment of the natives ... we must raise the status of the natives and they must be thought to realize that they are citizens of the empire ... all of this cannot be achieved unless the government ... a accept that a policy of native development is the only sound moral and businesslike way of dealing with the millions of blacks over

${ }^{94}$ Ainsworth to Acting Chief Secretary, 2 January 1920, Papers of Elspeth Huxley, Box 1/3, Rhodes House Library, Oxford. 
whom we have asserted our control. ${ }^{95}$

He felt that the ideal of African development could only be realized by maintaining tribal cohesion among the Africans. For Ainsworth, this meant separate development for Africans within their own reserves. By inculcating work habits within the reserves through development, the wants and needs of Africans would rise in support of a market. Ainsworth actually went on to state that, "in this connection it is necessary to bear in mind that any form of forced labor in this country cannot help but have the most disastrous results" because it made Africans detest work in general. ${ }^{96}$ In light of these statements, then, Ainsworth's association with the Northey circular was in keeping with his theory of African development. "Encouragement" of African labor was simply a means for African development. However, despite his advanced thinking on African development, Ainsworth, like many humanitarians and administrative officials, believed that "natives are much on par with children and therefore must be taught and brought up as decent and responsible members of state" otherwise "the result in the case of Africa would be uncontrolled savagery.",97

After criticism of the labor circular from the humanitarian wing, however, Ainsworth responded to the attacks in a way that clouded his motives for supporting the circular. In May 1920 he was asked to submit reports on the working of the labor circular in the colony by the acting Governor Bowring.

${ }^{95}$ Ainsworth to H. J. Read, 8 August 1913, CO 533/130

96“"Memorandum Dealing With Certain Proposals for the General Education of Natives in Native districts in the East African Protectorate," 30 April 1913, CO 533/130.

97،"Natives Work and Wages,” The Farmers Journal, 12 August 1920. 
In his report, Ainsworth downplayed the labor shortage in Kenya by stating that part of the labor problems were caused by conflicting European seasonal demand for labor and African harvest times. He stated that for years before the war, African chiefs and headmen had been active in "trying to prevent their young men from idling." 98 During the war this policy abated somewhat and the Northey Labor circular was simply an attempt to reinstill this work ethic.

In June 1920 Ainsworth compiled a memorandum that was initially intended for publication in the Journal of the African Society. The memorandum was written to specifically answer the humanitarian critics of the labor circular and was a bit of a departure from his previous statements on the subject. The Colonial office received its copy on 8 June 1920. In the memorandum, Ainsworth repeated some of the earlier arguments contained in his previous communications on African development. For Ainsworth, the crux of the labor problem was the inactivity of African men created by the onset colonialism. According to the Chief Native Commissioner, before colonialism Africans lived in a constant state of "raiding and counter raiding, strangers attacked without provocation.."99 Colonialism essentially acted as a calming mechanism by ending the strife and turmoil. However, this also had negative consequences according to Ainsworth. With the end of continuous warfare, the warrior class were left without any occupation. As Ainsworth stated, "this ordered state of affairs has resulted in tribes ... becoming slack and indolent and in large number of cases the people are inclined to habits of drinking and immorality." ${ }^{100}$ To remedy this situation Ainesworth prescribed work and more

\footnotetext{
${ }^{98}$ Memorandum on Native Labour Circular, 3 May 1920, CO 533/233.

99،"Some Notes Regarding Africa,” 8 June 1920, CO 533/233.

${ }^{100}$ Ibid.
} 
specifically work within the reserves.

In light of these facts, Ainsworth emphasized that the intent of the labor circular was to encourage Africans to work through lawful means. With reference to forced labor, he stated that although he disagreed with forced labor in principle, he did see its usefulness in particular cases. Forced labor for state purposes was one of the cases where conscription was necessary. Ainsworth added that "Native Authorities" have traditionally always had the authority to turn out labor in the reserves for the good of the community. Forced labor for state purposes was simply a continuation of this practice, according to Ainsworth.

Ainsworth's memorandum was a clear exposition of his views, including the contradictions. Essentially, he argued that modernization was responsible for the indolence of the African worker and subsequent break down of tribal unity. Yet, his prescription was more modernization. In defense of African development, Ainsworth came much closer to supporting coercion than he had in previous writings. This problematic support of coercion represented one of the fundamental problems with colonial rule and African development in Kenya. Was Kenya to be a "White Man's Country" or were Africans to be developed within their own institutions for their own good.

The CO received Ainsworth's memorandum with obsequious critique. After all, as A. C. C. Parkinson minuted, "it seems odd that an article on natives and native labour prepared by a man of Mr. Ainsworth's wide experience and knowledge should be criticised in any way by our department." ${ }^{101}$ Although the document was found to be unobjectionable, for the most part, there were some problems with the effectiveness of the writing and Ainsworth's acceptance of forced

${ }^{101}$ Minute by A.C.C. Parkinson, 23 July 1920, CO 533/233. 
labor. Milner decided against publication of the document.

Another barrage of criticism of administrative labor policy from a long time humanitarian critic, Dr. Norman Leys, elicited a more revealing response from Ainsworth. Leys had spent time in the EAP and Nyasaland between 1904 and 1913 as a medical officer for the administration. His experiences in East Africa turned him into an ardent critic of colonial policy. ${ }^{102}$ For example, in 1913 Leys publicly criticized the administration in Kenya over the evacuation of Maasai from their reserves, in violation of a previous treaty signed five years before that supposedly guaranteed the viability of their reserve. Leys public criticism of the administration in this case, dubbed the "Maasai Move," eventually resulted in his termination from the colonial service in the EAP. ${ }^{103}$ He was transferred to Nyasaland and soon had to retire due to medical difficulties associated with tuberculosis. Leys was quite active in criticizing the government and penned several letters to the Manchester Guardian in July 1921 criticizing colonial policy in Kenya.

In May 1921 Leys submitted a private letter and a memorandum he had written discussing the forced labor issue and colonial labor policy in the EAP to the Colonial Office. The documents were very critical of the colonial government in Kenya. However, since Leys had served in the colonial service, his criticisms carried some weight. As Parkinson minuted of Leys, "He has served in a good many parts of E. africa and for that reason in spite of his pro native fanaticism .. . is worth more concern than most of the anti slavery people."104 As a result, Ley's views on the

\footnotetext{
${ }^{102}$ For example, the view within the Colonial Office was, "Dr. Leys is an old enemy one of the fanatical group who never gave us much satisfaction in E af." Minute by A. C. C. Parckinson, 19 July 1921, CO 533/273.

${ }^{103}$ Minute by W. Bottomley, 23 December 1922, CO 533/289.

${ }^{104}$ Minute by A. C. C. Parkinson, 17 May 1921, CO 533/274. 
labor situation in Kenya were sent to Ainsworth for comment.

In his documents, Leys first criticized the notion that Africans are lazy. On the contrary, Leys stated that, "their industry and docility have made them slaves of the rest of the world. To work as hard as a nigger is a proverb that has always been true, whenever and wherever Africans have either been slaves or freemen." ${ }^{\text {105 }}$ Moreover, most Africans were habitually involved in some form of employment. ${ }^{106}$ At least three quarters, according to Leys, were involved wage employment and those not engaged in wage employment are always working on their own agricultural plots to feed themselves and their families. Consequently Leys stated, "now most natives do some of both kinds of work. Not one in a hundred does neither. There are no unemployed." ${ }^{107}$ For Leys, this was significant because, as he stated later, most Europeans defined wage labor as "real" work while the agricultural work done by Africans on their own farms was given secondary status. The inference was that only when Africans were working for wages were they seen as being industrious and eschewing idleness. For example, Leys pointed out that the 1920 amendment to the 1912 Native Authority Ordinance exempted Africans who had worked essentially for wages in the previous three months but not Africans who had worked on their individual shambas or estates. The actual ordinance did not specifically state that the labor had to be for wages in order to qualify as an exemption. However, it was understood by all administrative officials that non wage labor on individual plots was not sufficient as an exemption. Surprisingly, in a debate in parliament on October 27 1920, the Under Secretary of

\footnotetext{
${ }^{105}$ Memorandum by Dr. Norman Leys, 3 May 921, CO 533/274.

${ }^{106}$ Leys to Borden Turner, 3 May 1921, CO 533/274.

${ }^{107}$ Ibid.
} 
State for the Colonies, L. S. Amery, actually gaffed and stated that non wage employment on farms individual farms was an acceptable exemption from the 1920 ordinance. ${ }^{108}$ For Leys, the reason for this disregard for African labor on their own farm plots was economic. As he stated, "we may be quite certain that the promise to exempt the peasant cultivator will not be kept. He is the very man who is wanted for plantation and railway." 109

Leys stated flatly that it was the policy of the government to induce Africans to work for Europeans. This according to Leys was accomplished through taxation and compulsion. For Leys, taxation was not as effective as compulsion. Africans could simply increase production to pay it. As a result, compulsion was the chief means of pushing Africans into labor field. According to Leys, the state accomplished compulsion by instructing chiefs to send men to work. The syntax of "encouragement" or "moral suasion" were simply guises for force. ${ }^{110}$ Regarding the autonomy of the African chiefs and headmen in interpreting these commands, Leys made it clear that, "to both European and Native, refusal to follow a magistrate's instructions is sedition, that is an inevitable consequence of two factors, the utter powerlessness of the natives to influence law and administration ..."111

Leys concluded his remarks by equating compulsion with slavery. He also stated that the machination of compulsion was a reflection of an unjust and abusive government. Perhaps,

${ }^{108}$ On 27 October 1920, the Under secretary of State for the Colonies stated that "if a native has been fully employed in cultivation for himself for three months, he is exempt from the provisions of the Native Authority amendment Ordinance, 1920." Great Britain, Parliamentary Debates, Commons, $5^{\text {th }}$ Ser., vol. 133 (1920), col. 1742.

${ }^{109}$ Leys to Borden Turner, 3 May 1921, CO 533/274.

${ }^{110}$ Ibid.

${ }^{111}$ Ibid. 
reflecting his socialist leanings, Leys added that forced labor was fundamentally wrong because it turned Africans into instruments of production for European settlers. ${ }^{112} \mathrm{He}$ also called for the abolition of forced labor for public works calling for a free labor market where economic imperatives governed choice. In a free labor argument similar to that of the ASAPS, Leys argued that a free labor market would improve efficiency.

As mentioned previously, Leys documents were sent on to Ainsworth, who was on retirement leave in England, for comment. By this point, the CO under Winston Churchill and E. F. L. Wood was beginning to move towards an eventual despatch on the labor issue in Kenya. The memorandum, plus Ainsworth's comments, would prove useful in addressing points of detail surrounding the controversy occasioned by the circulars. ${ }^{113}$ In addition, Ainsworth's main points raised in his memorandum were to be brought up with Governor Northey in a meeting with Churchill. $^{114}$

Initially, Ainsworth was quite critical of the document and his insights provide an illuminating perception of the labor issue in Kenya from an official on the ground. In terms of the unpaid agricultural work of Africans on their individual plots, Ainsworth pointed out that 85 percent of the agricultural work was done by women. ${ }^{115}$ Many young men of the warrior grade did not perform menial duties in the home due to traditional or customary prohibitions. Consequently, he cast doubt on one of Leys' assertions that all Africans were employed in either

${ }^{112}$ Ibid.

${ }^{113}$ Minute by W. Bottomley, 18 June 1921, CO 533/273.

${ }^{114}$ H. Read to Ainsworth, 22 June 1921, CO 533/273.

${ }^{115}$ Ainsworth to H. J. Read, 7 June 1921, CO 533/273. 
wage or unpaid personal agricultural labor. He added facetiously that the only way Leys's statement could be accurate is if he included "annexing a stray goat or sheep here and there, wholesale fornication, dancing, drinking and generally defying their elders ..." as employment. ${ }^{116}$

Continuing along this line of argument, Ainsworth defined the general rule adopted by most administrative officials of acceptable work for African men as "work in your in Reserve at production for yourselves and your community or work outside for wages." 117 Ainsworth's statement contradicted the notions of acceptable African labor under the 1920 Native Authority Amendment Ordinance. Ainsworth's position also contradicted that of O. F. Watkins, the CNC in March 1921. Watkins stated that individual work on private plots could never suffice for exemptions under the 1920 Native Authority Amendment Ordinance due to the difficulty in proving that Africans had worked. ${ }^{118}$ Viewed in another way though, Watkin's recognition of permissible African labor was an admission that work on personal plots could not closely monitored by the state and did not contribute to accumulation on the part of the state. So, essentially, it was not labor. It was a reflection of the contradictions the state faced regarding peasant production versus estate or settler production. Although Ainsworth's viewpoint of African labor was not as clear elucidated, by 1925 the CO, under Amery, and the administration

${ }^{116}$ Ibid.

${ }^{117}$ Ibid.

${ }^{118}$ This issue caused embarrassment for the CO. On 27 October 1920, the Under secretary of State for the Colonies stated that "if a native has been fully employed in cultivation for himself for three months, he is exempt from the provisions of the Native Authority amendment Ordinance, 1920." Hansard Debate, Extract, 27 October 1920, Box/141, BFASAPS, Rhodes House Library, Oxford. 
would make it clear that only work for commodity production was indeed work.

Concerning the 1920 Native Authority Amendment Ordnance, however, Ainsworth basically agreed with Leys that the ordinance had a negative effect and was not necessary. As he stated, "the Native Authority Amendment Ordinance 1920 is, I feel, undesirable, it will continue to make for misunderstandings while it is no particular benefit to government departments." 119 Although Ainsworth believed that the administration should promote industry and do everything to encourage young men to go out into the labor market, he believed that "neither District Commissioners, Chiefs or Headmen should recruit ..." ${ }^{120}$ He concluded that forced labor was economically unsound.

The conformity of opinion on government forced labor between Ainsworth and Leys was not missed by some of the officials within the CO. ${ }^{121}$ The fact that a respected administrative official within the EAP basically agreed with some of the humanitarian criticism of Kenya's labor policy cast further doubt on the labor policy associated with Governor Northey. As R. Maxon has stated, within the CO, “Ainsworth confirmed Ley's view that Northey's circular was wrong and in need of considerable altercation." ${ }^{122}$ Ainsworth's views were put in the form of a draft circular that was to be presented to Northey for consideration of a new policy. In addition, the views of Leys and Ainsworth confirmed that the power of knowledge, the correct knowledge of African development resided with the state and the $\mathrm{CO}$ and not the humanitarian lobby. On another level,

\footnotetext{
${ }^{119}$ Ainsworth to H. Read, 7 June 1921, CO 533/273.

${ }^{120}$ Ibid.

${ }^{121}$ Minute by W. Bottomley, 28 June 1921, CO 533/274.

${ }^{122}$ Maxon, Struggle For Kenya, 196.
} 
the crisis of the Northey circular was a reflection of a struggle between the humanitarian lobby and the government over who knew what was best for the African peasant. In Kenya, the expert knowledge of African institutions and values was part of the political apparatus of legalized rationalized domination. ${ }^{123}$ As a device of trusteeship, correct knowledge of how best to rule the Africans was also an instrument of legitimation of the colonial state.

Besides Ainsworth, Acting Governor Bowring had also sought the opinions of other administrative officers as to the workings of the labor circular. He stated that many of them indicated that the labor circular was more or less a repetition of previous policy and had not had much effect. ${ }^{124}$ Of course, Bowring was both right and wrong. There was internal protest against the circulars, as mentioned previously, but, on the other hand, the circular was in essence the denouement of labor policy in Kenya Colony. The implication of this final devolution of colonial labor policy in Kenya was beginning to come under question.

Missionary criticism of the Northey circular also vacillated and was ambiguous. As reflected in the Bishops Memorandum, the response from the missionary sector within the EAP to the Northey Circular seemed to indicate a lack of complete confidence in the policy and yet was also mistrusting of the alternative, African initiative without compulsion. Besides the Bishops Memorandum, the Alliance of Protestant Missionary Societies in Kenya issued a minute in May 1920 from one of their meetings that added to the climate of compulsion created by the Northey Circular.

The minute dealt with "natives and labour" and was based on the Bishop's memorandum in

\footnotetext{
${ }^{123}$ Berman, Control and Crises in Colonial Kenya, 32-33.

${ }^{124}$ Bowering to Milner, 8 June 1920, CO 533/233.
} 
its conclusions. For the Alliance, the African was a "raw native . . not from want of capacity but from lack of opportunity." 125 Through education, the Alliance of Missionary Societies argued, Africans could better themselves ultimately approaching civilization. However, until Africans reached that point, the Alliance recognized the necessity of compulsion. Much like the Bishops' Memorandum, the Alliance of Missionary Societies called for legalized compulsion not veiled in the language of advice or wishes. The Alliances's statement called for legalized compulsory labor for a period of up to 60 days for all able bodied African males between the ages of 17 and 27 years old. ${ }^{126}$ In addition, Africans would be paid market wages. The statement by the Representative Council of the Alliance of Missionary Societies was a logical conclusion to the Northey Circulars and the Bishop's Memorandum.

On the other hand, Archdeacon Walter Owen, the Archdeacon of Kavirondo from 1918 to 1945, was also a vociferous critic of colonial abuses. He was known best for his duplicitous promotion of African welfare through the Kavirondo Tax payers Association. Although he focused on many abuses like forced marriages and child labor throughout his tenure, he was, also, active in shedding light on abuses associated with forced labor, in particular communal forced labor. His campaign against forced labor embodied the missionary's contradictory position as defender of African rights and promoter of beneficent colonialism.

For example, In October and November 1920 Owen found cases of forced labor for private individuals in Kisumu. In both cases, according to Owen, a DC wrote a letter of introduction in $533 / 233$.

${ }^{125}$ Minute by Alliance of Missionary Societies, "Natives and Labour," 17 May 1920, CO

${ }^{126}$ Minutes passed by Representative Council of Alliance of Protestant Missionary Societies, 17 May 1920, CO 533/233. 
Kiswahili for European employers that allowed them to get labor through chiefs and headmen. This letter of introduction, essentially acted like a pass and was, implicitly, state recruitment of forced labor for private individuals. Recruiters who had the letter were able to obtain more labor than those who did not. ${ }^{127}$

In a separate incident on 27 October in Kisumu, Owen again complained of government recruitment for private purposes. In this case, the headman, Kiuani wa Thika, actually diverted girls intended for a government thatching project to a planter named Hill in Thika. ${ }^{128}$

But even his criticisms was not without inconsistencies. Despite this criticism of colonial policy, Owen was still mired in the pathos of paternalism. At the height of the controversy over the Northey Circulars, Owen's attached his name to a very pro settler document, "A Defense of Kenya" that offered support for the institution of forced labor. We will examine this document later.

African response or African agency, in light of the climate surrounding forced labor, was localized and more focused around specific abuses associated with government forced labor. ${ }^{129}$ There would be no Africans submitting memorials to the S of S complaining about the Northey circular. Instead, African discontent with specific aspects of forced labor machinated at the local level and in some cases actually filtered all the way to the Colonial Office in London.

127“"Report of Sub Committee of Representative Alliance," File: Forced Labor 1920-1927, Owen unofficial Papers, CMS Archives, University of Birmingham, Birmingham.

${ }^{128}$ Mckerrick to Owen, 1 November 1920, "Forced Labor 1920-27," Owen Unofficial Papers, CMS Archives, University of Birmingham, Birmingham.

${ }^{129}$ However, one missionary believed that mission educated Africans were aware of the implications of the Northey circular. Reverend Earnest Spanton to Oldham, 23 December 1920, Box 240, File Miscellaneous Correspondence Regarding Approaches to CO in 1920, IMC/CBMS, SOAS, London. 
A letter to the Secretary of the Alliance of British Missionaries in East Africa, Dr. S.E. Jones on 24 June 1921 contained a list of grievances by the Kikyuyu Association ${ }^{130}$ against communal forced labor in Kiambu District in Central Kenya. ${ }^{131}$ The letter eventually was forwarded to the ASAPS which in turn forwarded it to the Colonial Office for consideration. ${ }^{132}$ The Kiambu chiefs complained about young girls being forced out to work and not being allowed to return home at night. This, according to the chief's, left the girls prey to sexual misconduct by the retainers since most of the girls were unmarried or recently married. They, specifically, alluded to a case of a yong girl who was taken to the European plantation of Young and Newton and not allowed to return home for three months and consequently was impregnated. They, also, stated that if they did not produce enough girls for labor projects they were detained. Tribal retainers would detain fathers if the clan head was not able to produce 30 girls at a time. The chiefs originally complained to the Chief Native Commissioner, Watkins, and were informed that there were no government orders requiring girls to work.

The chiefs, mainly Kinyanjui wa Gathirui, Nedewa wa Chege and Koinange wa Mbiu, directed their strongest comments against abuses of power by a headmen, Waiganjo wa Ndota. Mainly, they resented power he wielded and abused because, according to the chiefs, he was not a legitimate ruler. He took clan council fees even though he was not part of the kiama or clan council. Ndota had also been responsible for assaults and defacements against some of the

\footnotetext{
${ }^{130}$ This association was formed in 1919 to promote the interests of Kiambu landed elites, chiefs and headmen, among the Kikuyu, against further land alienation. Despite their protests, this organization was seen as conservative and in league with the colonial state.

${ }^{131}$ Tease to Jones, 24 June 1921, IMC/CBMS, Box 240, East Africa and Native Labour, File: Missionaries on the Field, SOAS.

${ }^{132}$ John Harris to E. F. L. Wood, 26 August, 1921, CO 533/272. 
chiefs. The letter of complaint ended with a list of girls who had become impregnated while working on plantations and the names of the men responsible.

Female and child labor abuses on forced labor projects were corroborated by missionary accounts. Archdeacon Owen brought to light several cases of abuse involving young women and children on road projects. In one case Owen was informed that a large contingent of young boys and girls from Alegyo (Elgeyo) were being used on a project to cut grass in Nyeri district that involved an overnight stay. ${ }^{133}$ Owen wrote to the Chief Native Commissioner inquiring about this incident. ${ }^{134}$ The CNC, Watkins, replied, sarcastically, that the government did not take notice of alleged abuses but, if Owen thinks there are abuses he will be glad to investigate. ${ }^{135}$

As reflected in the letter by the KA, using young girls on communal labor projects was fraught with the potential of abuse, particularly if the work involved overnight stays. Girls required to stay overnight at a work site were vulnerable to sexual abuse. In one particular case the missionary Reverend A. W. McGregor reported that the DC of Fort Hall was widening roads between the Maragou and Marhingo rivers in October 1920. As a result, Mcgregor reported that all of the available population of young women and girls plus elderly men and young men were turned out to labor. ${ }^{136}$ Many of the laborers could not return home at night due to the distance

${ }^{133}$ A. C. Irvine to Owen, 22 November 1920, "Forced Labor 1920-27," Owen Unofficial Papers, CMS Archives, University of Birmingham, Birmingham.

${ }^{134}$ Owen to O. Watkins, 3 December 1920, "Forced Labor, 1920-27," Owen Unofficial papers, CMS Archives, University of Birmingham, Birmingham.

${ }^{135}$ Watkins to Owen, 2 December 1920, "Forced Labor, 1920-27," Owen Unofficial Papers, CMS Archives, University of Birmingham, Birmingham.

${ }^{136}$ A. W. McGregor to Owen, 25 October 1920, Church Missionary Society Archives, Owen Unofficial Papers, File: “Forced Labor 1920-27," University of Birmingham, Birmingham. 
and some were not able to return home for 10 to 12 days. Consequently, according to McGregor, some of the unmarried girls were forced into "immorality" by tribal retainers. On this theme, another missionary, John Arthur, gave the example of a young girl on a work site who was raped by six different tribal retainers. ${ }^{137}$

In addition to the complaints of sexual abuse, Africans also suffered from a labor process that was anything but systematic. For instance, requirements of forced labor were distributed disproportionately. In most cases the poor, women or children would be forced to labor. As the Provincial Commissioner of Nyeri, H. R. Tate, attested, the labor requirements of the Native Authority amendment disproportionately fell upon the poor. ${ }^{138}$ Owen also frequently encountered the young and poor on forced labor projects. ${ }^{139}$

Another African complaint was the lack of systematic methods of procuring labor under the Native Authority ordinance. One missionary in Fort. Hall district wrote of a young man who had just been released from employment in Nairobi. Unfortunately for him, he reached home on the last day when they were calling out people for forced labor in his home area and was subsequently drafted for a labor detail. He refused to go and was fined. ${ }^{140}$ In another example reported to the DC of Kisumu, a teacher, Samuel G. Obeoth, complained that he had been

\footnotetext{
137“"Memorandum by John W Arthur.," 24 December 1920, Box 239, File: "Evidence of Abuses," IMC/CBMS, SOAS.

${ }^{138}$ H.R. Tate to Acting Chief Secretary, 13 January 1920, Papers of Elspeth Huxley, Rhodes house Library, Oxford.

139،"Report of the Sub Committee of the Representative Alliance," File: "Forced Labor: 1920-27," Owen Unofficial Papers, CMS Archives, University of Birmingham.

${ }^{140}$ Reverend H. Mckenrick to Dr. S. E. Jones, 8 August 1921, Box 240, File: "Missionaries on the Field," IMC/CBMS, SOAS, London. Mckenrick also added that the usual fine was one sheep but Headmen frequently fined men four sheep.
}

Page -203- 
detained six months for work by the local headman as opposed to the customary 24 days for communal labor. ${ }^{141}$ One missionary complained that it was hard to limit the amount of days people worked. ${ }^{142}$ In addition, the call for labor frequently conflicted with the time Africans needed to be in their fields to guard against pests. ${ }^{143}$

\section{Oldham and the Conclusion of the Crises}

Around June of 1920, J. H. Oldham, Secretary of the Conference of Missionary Societies, ${ }^{144}$ became involved in the forced labor controversy in Kenya Colony through his contacts with J. H. Harris, the organizing Secretary of the ASAPS. Due to his position and important contacts, Oldham was able to bring more influential people into the forced labor conflict that was ultimately attenuated under Churchill in 1921.

Harris wrote Oldham on 4 June 1920 informing him of the controversy in East Africa and also attacking the statements of the Representative Council of the Alliance of Missionary

${ }^{141}$ Owen to S. Murtland, 29 October 1920, File: "Forced Labor 1920-27," Owen Unofficial Papers, CMS Archives, University of Birmingham, Birmingham.

${ }^{142}$ Marion Stevens to Oldham, 13 October 1921, Box 240, File: "Missionaries in the Field," IMC/CBMS, SOAS, London.

${ }^{143}$ Ibid.

${ }^{144} \mathrm{An}$ organization that included 31 Protestant missionary societies in Great Britain and Ireland. Oldham would also serve on the Commission on Closer Union in East Africa in1925. His interest in East Africa was driven by a strong belief in trusteeship and so called "native" education. He would also become involved in Negro education in the United States. After the Northey Crisis, Oldham turned his attention to the problem of Indian representation in Kenya. For further information see John Cell, ed., By Kenya Possessed, (Chicago: University of Chicago Press, 1976). 
Societies regarding African labor. ${ }^{145}$ On 9 June 1920 Oldham wrote to Dr. Norman Leys asking him for a brief synopsis of the issues involved because as he put it "I have as you know no personal knowledge of conditions in East Africa ..."146 Leys responded in an uncharacteristically succinct letter the next day. In his letter Leys' main points were that African's were not lazy and that compulsion was equal to slavery. He added that, "forced labor for private purposes ... could not be supported by anyone who accepts the Gospel in politics." ${ }^{147}$

Oldham began to marshal his considerable forces among religious, business and philanthropic organizations. Oldham's strategy was to enlist the help of important men in the religious, business, academic and political sectors of London to petition the CO for a Royal Commission on labor in East Africa. ${ }^{148}$ His ultimate goal was a reorientation of Colonial Office policy in regards to Kenya.

At a meeting of the Conference of Missionary Societies in June of 1920, Oldham received evidence from missionaries in the field of labor abuses in Kenya. Oldham along with the Archbishop of Canterbury, Randall Davidson, decided to advance the idea of a Royal Commission on the labor problem in East Africa.

\footnotetext{
${ }^{145}$ Harris to Oldham, 4 June 1920, Box G 141, "Correspondence about Forced Labor, Land, Cotton and Trusteeship,” BFASS/APS, Rhodes House Library, Oxford.

${ }^{146}$ Oldham to Norman Leys, 9 June 1920, Box 248, "East Africa Correspondence," IMC/CBMS, SOAS, London.

${ }^{147}$ Leys to Oldham, 10 June 1920, Box 248, File: "East Africa Correspondence," IMC/CBMS, SOAS, London.

${ }^{148}$ Some of these notables included: Lionel Curtis, R. H. Tawney, Leonard Woolf and Ramsay Macdonald of the Labour Party, Sir Valentine Chirol and Sir Arthur Steel-Maitland the Conservative MP.
} 
On 18 June 1920 Oldham, through his position as secretary of the Conference of Missionary Societies, wrote a lengthy letter Lord Milner, the Secretary of State for the Colonies. In the letter he stated that "we reluctantly admit the necessity of compulsory labor in certain cases ..." that dealt with public utility provided there were safeguards. ${ }^{149}$ Alluding to Cromer's earlier memorial published by the ASAPS, Oldham likewise equated forced labor for private purposes with slavery and deemed it unjustifiable. Oldham suggested replacing corvée labor with taxation by allowing people to pay off their corvée labor requirement through some sort of tax remittance. He also criticized the policy of letting women work away from their homes overnight. He felt that this encouraged vice and sexual exploitation. The CO responded to Oldham's letter by sending him a copy of the Masters and Servants Ordinance. ${ }^{150}$ In addition, the CO informed Oldham that a new circular was being written and it would send him a copy when it was finished. This revised circular would eventually be issued by Milner on 1 July 1920 was supposed to curb the powers of the colonial chiefs. However, as we shall examine later, it did not go far in assuaging the fears of Oldham and other humanitarians.

Following Oldham's letter, separate missionary organizations within the Conference of Missionary Societies also began to communicate with the $\mathrm{CO}$ in regards to the labor situation in Kenya. On 8 July 1920, F. Marcus Wood, Secretary of the China Inland Mission, wrote to Milner expressing anxiety that the principles imbued in the Northey circular represented a departure from the declared policy of the British government. ${ }^{151}$ The Baptist Missionary Society

\footnotetext{
${ }^{149}$ Oldham to Milner, 18 June 1920, Box 238, File: “Government Schemes, Lord Milner's Despatches," IMC/CBMS, SOAS, London.

${ }^{150}$ Read to Oldham, 26 June 1920, Box 240, File: Colonial Office, IMC/CBMS, SOAS.

${ }^{151}$ F. Marcus Wood to Milner, 8 July 1920, CO 533/249.
} 
followed suit on 22 July. Their letter reiterated some of Oldham's themes against the circular. ${ }^{152}$ They, also, stated that any attempt to recruit labor from Tanganyika, as stated in Northey's original circular, went against the covenant of the League of Nations. Following the Baptist Missionary Societie's protest letter, similar letters arrived at the CO from the Primitive Methodist Missionary Society, the London Missionary Society, and the Bath and Wells Diocesan Conference.

While Oldham marshaled his forces, ASAPS efforts regarding forced labor in Kenya culminated in a parliamentary debate on 14 July in the House of Lords. On that day, Lord Islington, chairman of the Joint Committee on Indian Affairs, arose to ask the Secretary of State for the Colonies whether he would state the policy of the government regarding natives of India residing in British East Africa. ${ }^{153}$ The great debate on East Africa had finally arrived. Islington continued by asking the $\mathrm{S}$ of $\mathrm{S}$ to also address the issue of "native" labor in British East Africa as well. He added that the subject of "native" labor and Indians in British East Africa had a much wider scope concerning issues of imperial rule ans trusteeship. After an opening statement concerning the Indian problem in East Africa, Islington turned to the labor problem of the Northey circular. He framed the labor problem Kenya in terms of "high imperial importance."154 According to Islington, the problem with the Northey circular was that it infringed upon the principles of which govern the British empire. Alluding to Lord Cormer's famous dictum that forced labor for private profit was synonymous with slavery, he went on to critique several facets

\footnotetext{
${ }^{152}$ Chas Wilson to Milner, 20 July 1920, CO 533/249.

${ }^{153}$ Great Britain, Parliamentary Debates, Lords, $5^{\text {th }}$ ser., vol. 41 (1920), No. 60.

${ }^{154}$ Ibid.
} 
of the circular that had aroused the humanitarian ire. Islington then closed his speech with a call for a Standing Advisory Committee composed of representatives of the Foreign Office and India Office with a representative Indian national picked by the Secretary of State.

Following Islington's speech, the Archbishop of Canterbury spoke in more guarded tones along the same lines of principle as Islington. He stated that the problematic issues surrounding the Northey circular reflected the wider axioms governing British treatment of "child Peoples." 155 Davidson pointed out that Kenya was being developed for both Europeans and Africans. So, the direction of British rule should be to guard against abuses inherent in the policy reflected in the circular. He went on to list some of the classic abuses associated with the system such as the abuse of power by African administrative personnel and sexual assaults on labor projects involving overnight stays for African women. ${ }^{156}$ The rest of the Lords who spoke on the labor issue in East Africa, Bryce, Emmot and Mayo, all reiterated Islington's themes and emphasized that Great Britain needed to adhere to the principles reflected in the League of Nations regarding mandates even though Kenya was not a mandate territory.

For his part, Milner skillfully deflected some of the issues raised. He left the issue of an Advisory Council in the air but added that Islington's proposal did not make room for a European representative. Milner took this as a reflection of the view that the $\mathrm{CO}$ did not effectively represent the interests of Africans and Indians. He then proceeded to state that problem of labor in Kenya was one of steering a middle ground between production for Europeans and the idleness of Africans. Milner stated that "there is no difference really between administrators and those

\footnotetext{
${ }^{155}$ Ibid.

${ }^{156}$ Ibid.
} 
who have lived long in the country . . above all the missionaries . . . as to the vital importance to the natives themselves of encouraging them to more steady and continuous industry." 157 He then listed some of the progressive accomplishments of the administration in regards to African betterment. The debate closed on the topic of the Indians in East Africa. In the aftermath of the debate Harris and Islington were hopeful for the appointment of an Advisory Committee to further delve into the issue in East Africa.

Following the debate, Lord Milner issued a despatch to the governor of Kenya on 22 July 1920. In the despatch, Milner stated, " that considerable interest has been aroused by the publication of the Northey labour circular of 23 October 1919 in many quarters." 158 Milner did not completely disavow forced labor. He accepted the necessity of compulsory labor of able bodied African men for 60 days a year on government work of a public nature, such as the building of bridges, railways and roads along. ${ }^{159}$ This was legislated in the 1920 amendment to the Native Authority Ordinance. Milner also accepted the encouragement of female and child labor for work on private farms provided they returned from the work site at night unless the husband was also employed on the plantation. He borrowed form his earlier conversation with Governor Northey by stating that most of the work done by the women was non arduous coffee picking which the women enjoyed anyway. However, Milner did state clearly that the Colonial Office rejected compulsory labor for private purposes but favored encouragement of labor in the

${ }^{157}$ Ibid.

${ }^{158}$ Great Britain, Despatch to the Governor of the East Africa Protectorate relating to Native Labour and Papers Connected therewith, cmd. 873, (22 July 1920), 3.

${ }^{159}$ Ibid. 
form of advice. ${ }^{160}$ Milner concurred with Northey that African idleness was the main problem.

As he stated,

I do not hesitate to accept your opinion, which my own experience corroborates, that in their own interest they should seek outside employment, when not engaged on work in their own reserves ... it is desirable that young, able bodied men should become wage earners and should not remain idle in the reserves for a large part of the year. ${ }^{161}$

Milner noted that the Bishops Memorandum concurred with his opinion as well. Regarding African chiefs and headmen, Milner did not follow the lead of the humanitarian lobby and the missionaries in the field and call for their dismissal from the forced labor regime. Noting the obvious fact that the chiefs or headmen level were a necessary element of colonial rule, Milner simply called for more safeguards.

Milner's ambivalent despatch in regards to forced labor proved unsatisfactory to many in the humanitarian lobby. The ASAPS received a copy of Milner's despatch on 11 August 1920. The society responded to the $\mathrm{CO}$ on 22 October 1920 in a lengthy letter that also included the signatures of Henry Bentinck and Sydney Olivier. ${ }^{162}$ In their correspondence with the CO the ASAPS, for the first time, focused on the issue of communal labor. They noted that Milner's despatch and also his speech during the debate in the House of Lords on 14 July indicated that the 1920 amendment to the Native Authority Ordinance was the limit of state coercion of African labor. The ASAPS pointed out, however, that in actuality Africans were liable for both work on

${ }^{160}$ Ibid., 4.

${ }^{161}$ Ibid., 5 .

${ }^{162}$ Charles Roberts to Colonel Amery, 22 October 1920, CO 533/249. Lord Henry Cavendish Bentinck was a Liberal MP. Lord Olivier was also a member of the ASAPS.

Page -210- 
projects under the 1920 Amendment and the original Native Authority Ordinance, section $8 \mathrm{~h}$. Under section $8 \mathrm{~h}$ able bodied men were liable for work on works projects for the good of the community for up to six days a quarter or 24 days a year. This amounted to a forced labor penalty of up to 84 days a year.

The society went further and made the bold assertion that the purpose of the duties required under the 1920 amendment to the Native Authority Ordinance and section 8h of the original 1912 Native Authority Ordinance were not self delineating categories. ${ }^{163}$ In essence, they served the same purpose, primitive accumulation, apropos African labor, for the colonial state.

In closing, the Society compared the forced labor regime in Kenya to that of the Soviet Union and criticized Milner's despatch for supporting Northey's contention that Africans should come out of the reserves to work on European plantations. Instead, the ASAPS hoped that encouragement would be given "to the indigenous worker to cultivate his own land and develop it to the utmost of his ability." 164

The $\mathrm{CO}$ responded to the ASAPS letter with indignation. An extremely long minute on the ASAPS letter from W. C. Bottomley of the $\mathrm{CO}$ was illustrative. In his minute, Bottomley lamented that one of the problems with the position taken by the ASAPS was total lack of regard for the principle behind the labor regime in Kenya. Bottomly stated that the purpose of the labor arrangements was "to turn to useful account the young able bodied natives who at present are idling in the reserves and doing no good to themselves or anyone else." 165

\footnotetext{
${ }^{163}$ Charles Robert to Colonel Amery, 22 October 1920, CO 533/249.

${ }^{164}$ Ibid.

${ }^{165}$ Minute W. C. Bottomley, 26 October 1920, CO 533/249. 
The CO response to the ASAPS in November was a "stiff reply" and reflected further consultation on the matter with the former Chief Native Commissioner of Kenya, John Ainsworth. In the letter, drafted by Bottomley, he reemphasized that part of reasons for the requirements of forced labor was due to African idleness and sloth in the reserves. The letter alluded to a previous memo by Ainsworth that stated that with the onset of civilization many "warrior" tribes were becoming slack and indolent leaving them prone to abuses of alcohol and other immoralities. The coerced labor provisions combated this problem. In addition, concerning the communal labor provisions under section $8 \mathrm{~h}$ of the 1912 Native Authority Ordinance, the letter essentially stated that these duties were "a matter of native custom" and merely represented the continuation of traditional duties owed to the chief any way.

The ASAPS was not the only critic of Milner's despatch. Frank Weston, the Bishop of Zanzibar, complained in a letter addressed to the Prime Minister in November that, "the Colonial Office has just set its seal to a new policy of forced labour for the state with a view of securing workers for the European settlers." 166 Weston added that coercion of labor was usually carried out under the threat of violence by authorities. The bishop of Zanzibar lambasted Milner stating that he had given Africans their fate, forced labor for Europeans. Weston construed that, under forced labor, Africans were being coerced into labor for both the government and Europeans, in the form of encouragement. Weston called the policy of forced labor moral madness and unchristian. However, he did not go as far as condemning communal labor. Regarding communal labor, Weston agreed that "the community may rightly be expected to preserve its

\footnotetext{
${ }^{166}$ Weston to Prime Minister, 1 November 1920, CO 533/249.
} 
local roads, etc., and to supply officials with carriers for local journeys."167 He ended his letter with an ominous portend of impending African rebellion if the labor situation was allowed to continue in the present direction. Weston would, also, later publish a short pamphlet, "Serfs of Great Britain,” in response to Milner's despatch that also condemned the poliy of the Northey circulars. $^{168}$

Controversy surrounding Milner's circular extended into newspapers. An editorial in the New Statesman the following month suggested that, based on Milner's despatch, it might be better to mandate legalized compulsion in Kenya. ${ }^{169}$ The editorial went on to equate compulsion with slavery and stated that it was not really needed. The editorial criticism of Milner's despatch took an innovative turn by pointing out the seemingly obvious fact that had been missed by both apologists for forced labor and humanitarians. Conscription of labor under a democracy was a far different affair than conscription of labor where the participants do not have a say so in their government. The ASAPS and Oldham and his allies never critiqued forced labor in this way because colonial rule was the assumption. Africans were essentially "children" who had to be guided along the way civilization. The only question that remained pertained to the form of progressive subjugation.

The editorial closed by pointing out that Milner's argument that the prevention of idleness was the main purpose behind coercion was eerily similar to the arguments used by industrialists during the early days of the industrial takeoff in Great Britain. This basically unmasked the

${ }^{167}$ Ibid.

${ }^{168}$ Frank weston, Serfs of Great Britain, (London: W. Knott, 1920).

169““Our African Scandal,” New Statesman, 18 December 1920. 
essential economic intent of forced labor despite all of the rhetoric of idleness.

However, not all voices were critical. An editorial in the EAS in November was alarmed at the attacks on labor policy by the ASAPS, Exeter Hall and "advanced liberal journals." defense of the settlers the editorial stated that, "we do not preach capitulation; we believe the ordinance to represent a valid defensible principle."171 The editorial went on to state that although the settlers "recognised that compulsory labor for private individuals is not to be sanctioned" but “. . . justifiable compulsion for public works must react favourably on the private labour market." 172

Back in London, dissatisfaction with Milners circular emboldened humanitarian initiative. Milner's despatch disappointed Oldham but pushed him to move for a restatement of policy. He received his copy of Milner's despatch on 11 August 1920. On 30 September 1920 Oldham along with the missionaries Handley Hooper and Donald Fraser of the Church Missionary Society, John Harris of the ASAPS, and Frank Weston, the Bishop of Zanzibar, met to discuss what action ought to be taken in regards to the labor situation in Kenya in light of the unsatisfactory memorandum from Milner. The proposal that came out of this meeting became the basis for a memorandum, "Labour in East Africa and the Principle of Trusteeship," that Oldham would eventually submit to the S of S. ${ }^{173}$

In the meeting they agreed that forced labor for public purposes would be acceptable only as a

\footnotetext{
170“A Big Attack,” East African Standard, 16 November 1920.

${ }^{171}$ Ibid.

${ }^{172}$ Ibid.

${ }^{173}$ Notes of Discussion on Labor in East Africa, 30 September 1920, Box 238, File: "Notes to Meetings," IMC/CBMS, SOAS, London.
} 
necessary evil. Hooper pointed out that the negative effect of forced labor for public purposes was to drive the Africans into working for the Europeans. Weston, for his part, added that forced labor broke up communal village life by driving the Africans out of the reserves to work for Europeans.

Oldham and Harris saw African education as a definitive policy initiative of African development. In addition, Oldham, who had been supplied with information by the District Commissioner of Kenya H. R. Montgomery, proposed that African representation should be taken into account in the form of an appointed representative from the administration or missionary sector. ${ }^{174}$

The actual memorandum, "Labour in East Africa and the Principle of Trusteeship," was completed in November. ${ }^{175}$ In the memorandum Oldham stated that the Secretary of State's despatch did not allay humanitarian fears. Milner's reliance upon the Bishops' Memorandum inferred that legal compulsion with safeguards was acceptable. Consequently, even though he disavowed compulsion for private purposes, the machinery of government, according to Oldham, could still be used to place indirect pressure on the chiefs to procure labor. And, as for the chiefs, Oldham was supremely confident that they would be scarcely able to reconcile the instructions to guard against labor abuses while the pressure for recruitment went unabated. ${ }^{176}$

Oldham also had misgivings about the 1920 amendment to the Native Authority Ordinance.

\footnotetext{
${ }^{174}$ H. R. Montgomery to Oldham, 2 November 1920, Box 238, File: “Officials on the Field," IMC/CBMS, SOAS, London.

175،Labour in East Africa and the Principle of Trusteeship," Oldham to G. T. Manley, 8 November 1920, Letters G3 A5/o 1920-1922, CMS Archives, University of Birmingham, Birmingham.

${ }^{176}$ Ibid.
} 
He noted that the duties under which Africans could be called out were too wide and could be interpreted in varying ways. Oldham surmised that the exemptions in the clause are actually designed to push Africans into wage employment. Oldham was also concerned about the "prevention of idleness." 177 He stated that the focus on African idleness neglected the fact that Africans worked on their own plots. He added that the best way to encourage industry was through education.

Oldham believed that the principle of trusteeship demanded that Great Britain exercise control in the interests of subjugated people and not simply for colonial advantage. ${ }^{178}$ He added that article 22 of the League of Nations was an international sanction that Great Britain must abide by the ethos of trusteeship in regard to the interest of her "Native inhabitants."

In November, the Archbishop of Canterbury met Milner who then agreed to receive a deputation of important people organized by Oldham. On 14 December 1920 the Archbishop of Canterbury headed a deputation of notable people, organized by Oldham, to discuss the labor issue in East Africa and the possibility of a royal commission to explore the issues relating to labor in Kenya colony. ${ }^{179}$ These included such luminaries as the Lords Salisbury, Emmot, Brcye and Islington. As Oldham would later admit to Leonard Woolf in a private letter, a royal commission would be an important step towards the final goal of reorienting colonial policy regarding Kenya by bringing the issue before the public. ${ }^{180}$

${ }^{177}$ Ibid.

${ }^{178}$ Ibid.

${ }^{179}$ Oldham to Archbishop of Canterbury, 26 November 1920, Box 239, File: “Archbishop of Canterbury and Mr. Bell," IMC/CBMS, SOAS, London.

${ }^{180}$ Oldham to Woolf, 26 April 1921, Box 238, File "Labour Party,” IMC/CBMS, SOAS. Page -216- 
Following the meeting, Davidson wrote Milner a follow up letter stating that the members of the deputation would continue to agitate for a change in colonial policy, but, in a crafty maneuver, stated that he hoped a royal commission would bring forth the issue of trusteeship. ${ }^{181}$ Milner immediately responded on 20 December that he had never agreed to a commission of inquiry during the meeting with the deputation. He also wanted more specific evidence from Kenya of labor abuses.

Initially, Oldham was hesitant to acquiesce to Milner's demand, for he did not wish to disclose the names of his informants for fear of reprisal. Subsequently, Oldham wrote Milner on 21 December thanking him for receiving the deputation and again calling for a royal commission emphasizing a concern for the proper discharge of the trust principal in regards to the labor problem in Kenya. ${ }^{182}$ Oldham also hoped that if Milner did call for a royal commission the missionary sector would be adequately represented on the commission as the only true African voice. He also added that the conference of Missionary Societies had a large body of evidence from missionaries in the field. Oldham, however, did not address the issue of specific cases of abuse.

Consequently, $\mathrm{CO}$ again called for specific evidence. ${ }^{183}$ At this juncture, Oldham responded

${ }^{181}$ Davidson to Milner, 16 December 1920, IMC/CBMS, Box 238, File: “Colonial Office," IMC/CBMS, SOAS, London.

${ }^{182}$ Oldham to Milner, 21 December 1920, Box 238, File: “Colonial Office," IMC/CBMS, SOAS, London.

${ }^{183}$ Read to Oldham, 29 December 1920, Box 238, File "Colonial Office,” IMC/CBMS, SOAS, London. 
that he would forward Milner a memo of abuses via the Archbishop of Canterbury. ${ }^{184}$ On 5 January Milner received two memorandums of abuses form the Archbishop of Canterbury composed by John Arthur and Handley Hooper. Arthur had since repudiated the implication of his stance taken in the Bishops memorandum. ${ }^{185}$ In addition to the evidence of abuses from Hooper and Arthur, the memorandum submitted by Oldham also contained a mild reprisal of the Bishops infamous memorandum from Oldham. Despite this sharing of evidence, some of the evidence of abuses included private letters that Oldham withheld for fear of compromising his sources. $^{186}$

In reference to the Bishop's Memorandum, Oldham repudiated it by stating that it essentially advocated a system of legal compulsion that went against the traditional British policy regarding "native" people. In addition, Oldham also excerpted a letter from one of the original signatories of the Bishops memorandum, John Willis, the Bishop of Uganda. Dated 17 October 1920, Willis' letter obliquely endorsed Oldham's memorandum of abuses. In the letter, Willis did not repudiate his stance in the Bishop's memorandum, but simply stated that since the government was not willing to safeguard forced labor, which was one of the stipulations of the Bishop's

${ }^{184}$ Oldham to Amery, 1 January 1921, CO 533/250. Oldham left the country on a journey to the United States for two months in January.

${ }^{185}$ Arthur later wrote to Oldham that he had not taken necessary safeguards to avoid appearing to be in league with the government and the settlers.

${ }^{186}$ Although in a letter from Arthur to Oldham, it appears that his sources were DC's, Britton of Kavirondo, Barbour, Butcher and Kenneck of Kikuyu Province and Harris of the Coast Province. These names appear to have been aliases, though. Arthur to Oldham, 26 May 1921, Box 238, File: Officials on the Field, IMC/CBMS, SOAS, London. 
memorandum, he, Willis, was supporting Oldham's memorandum of abuses. ${ }^{187}$

Arthur's memorandum reflected a lot of the core issues of Oldham's campaign against forced labor. In his statement Arthur lamented that the central problem with forced labor in colonial Kenya was a lack of focus of government policy regarding African labor. ${ }^{188}$ This lack of focus, according to Arthur, came out in the problems of labor recruitment. The administration insisted there was no compulsion, but colonial chiefs "encouraged" labor. District officers varied in their interpretation of government "wishes." Some DC's forced out labor for recruitment on plantations while others did not. Those who did not suffered the wrath of the settlers. This pressure, coupled with the poll tax, according to Arthur, led to a depletion of the African population in the reserves, particularly among the Kikuyu. Above all, Arthur stated, there was constant pressure upon the chiefs to answer the call of the labor market. Consequently, he called for the removal of chiefs from the recruiting process. ${ }^{189}$ Arthur also called for increased African education but as a way of increasing voluntary labor. He then listed eight individual cases of abuses that had come to his attention. Although his memorandum was damming by implication, it did not, however, mention specific names attached to each particular case.

In one example, Arthur stated that after the publication of Northey's first circular an unnamed DC instructed a tribal retainer to collect young women for a month of work on an estate. In another example, Arthur asserted that "a school young man" told him that in July 1920 his sheep

\footnotetext{
${ }^{187}$ Willis to Oldham, 16 June 1920, Box 240, File: "Missionaries on the Field," IMC/CBMS, SOAS, London.

188،"Memorandum on Native Labour in East Africa submitted to Lord Milner as Requested during an interview," 14 December 1920, Box 239, File: "Memo on evidence of abuses December 1920 Submitted by J. H. Oldham,” IMC/CBMS, SOAS, London.

${ }^{189}$ Ibid.
} 
were seized by the tribal chief for refusing to work for the government. His reason for refusal was that he had just finished six months labor in Nairobi and was, therefore exempt. Arthur went to the local DC with this information and was told that the young man should have come to him when called by the chiefs to labor. However, Arthur's point was more salient and alluded to some of the difficulties of forced labor. Arthur asked rhetorically, "would the District official have ever seen the boy or his papers if he had gone to the government station?"190

Arthur stated that up to October 1920 there were repeated cases of young girls that were seized for government work projects and detained away from home for days at a time. In one particular instance, Arthur stated that a girl was sexually assaulted by six different tribal retainers in one night. This, according to Arthur, was one of the reasons missionaries in Kenya had been calling for an end to the practice of keeping girls away overnight on work projects under the Roads in Native Reserve Ordinance. Arthur concluded his memorandum with a description of the land tenure problem among the Kikuyu.

Hooper's memorandum more narrowly critiqued the abuses of forced labor as opposed to the principle of coercion. Like Arthur, he lamented the depopulation of the reserves due to the excessive labor and taxation demands placed upon the Africans. Specifically, he criticized the colonial administration's use of women in forced labor projects. Hooper stated that the application of the Native Authority Ordinance of 1912 and the Roads Ordinance of 1910 specifically called for able bodied men to labor for up twenty four days a year yet women and children were found in increasing numbers working on roads. Hooper attributed this to the African men being forced to work out of the reserves on private plantations. According to

190“Memorandum on Labour in East Africa," CO 533/250.

Page -220- 
Hooper, the increasing use of women on labor projects compromised the moral structure of life in the reserves. Tribal retainers responsible for women on the labor projects often took advantage of them. If the work involved overnight stays or was a considerable distance from their home areas women were prone to sexual misconduct. Ironically, Hooper placed most of the blame for this transgression of morality on the backs of the women. ${ }^{191}$ He also gave a specific example gleaned from Macgregor Ross, the former head of the Public Works department in Kenya Colony. According to Ross, in the Fort Hall district of Kikuyu Province in November 1920, girls and old men were frequently kept away from home on work projects exceeding 10 to 12 days.

At the end of the memorandum Oldham attached an extract of the report of the Belgium Royal Commission on abuses in the Congo. Although the evidence was damming, it is significant to note that Arthur and Hooper's evidence was purposefully vague. Hooper did not wish to list specific names attached to the abuses. As he stated, "the aim of the mission is to cooperate with government for the good of the native and I have no wish to attack particular officers ..."192 This indicates that the criticism was meant more as a rehabilitation of colonial policy regarding forced labor. Along these lines, Oldham also withheld evidence of abuses that had been given to him by Archdeacon Owen. His stated reason was that he did not want to do anything that looked like an

\footnotetext{
${ }^{191}$ In a separate letter to Oldham on 15 August 1921 Hooper actually stated that " $i$ have no doubt that the girls also often lure the tribal retainers to assault her." Handley Hooper to Oldham, 15 August 1921, Box 247, File: “H. D. Hooper," IMC/CBMS, SOAS, London.

192“"Memorandum by John W. Arthur.," 24 December 1920, Box 239, File: "Evidence of Abuses," IMC/CBMS, SOAS.
} 
attack on Northey. ${ }^{193}$ In this instance, humanitarian criticism appeared to be more a part of the colonizing enterprise than a separate body of dissent.

This lack of specific detail was problematic for the $\mathrm{CO}$, however. As Bottomley minuted, the problem with the accusations of abuse was also a problem of "the abuse of authentication" that made it difficult to "sift out what may be mere gossip." 194 However, the memorandum was sent on to Northey for comment. Northey replied to the memorandums on 21 May. In his reply, Northey denied that his circular implied coercion for private purposes. He stated that it was meant to encourage habits of industry among Africans. Concerning the memorandums, Northey stated that he did not believe the abuses were an indication of forced labor. ${ }^{195}$ At this point the $\mathrm{CO}$ was beginning to reappraise Northey's position due to Eliot's damming testimonial, as mentioned previously. ${ }^{196}$ The decision was to wait for Northey's return to England then have a meeting with him.

In March, a curious document appeared in the EAS from the Convention of Associations Kenya. The Document was entitled “A Defense of Kenya: Full Statement of Facts for Benefit of Critics." 197 The document was critical of attacks on colonial labor policy and was essentially an apologeia for settler rule emphasizing that before colonial rule only barbarism, famine and tribal

${ }^{193}$ Oldham to Owen, 29 April 1921, Box 5, Owen Unofficial Papers, CMS, University of Birmingham, Birmingham.

${ }^{194}$ Minute by W. C. Bottomley, 1 January 1921, 533/271.

${ }^{195}$ Northey to Churchill, 21 May 1921, CO 533/259.

${ }^{196}$ Maxon, Struggle for Kenya, 156.

197،“A Defense of Kenya,” East African Standard, 5 March 1921.

Page -222- 
warfare existed in "dark Africa." 198 Concerning forced labor, the document stated that the only real forced labor is communal labor. But, even this form of forced labor is to a large extent performed by women and children "always at the behest of the lazy male, parent, husband or local chief."199 The document also regarded the 1920 amendment to the Native Authority Ordinance as simply putting a legal sanction to a system of procuring labor in Kenya that had been in existence for some time. The "Defense" was written by the Convention's sub-Committee and, surprisingly, one of the signatories to the document was Archdeacon Owen.

While the CO was waiting for the Northey's report, Oldham sent a "Memorandum on Native Affairs in the East African Protectorates" to the S of S on 17 May 1921 that contained references to the statements of abuses from Reverend Handley Hooper of the CMS and John C. Arthur of the Church of Scotland Mission. Oldham again stated that he would not reveal specific names involved in abuses for fear of compromising the integrity of DCs in charge of areas where the abuses occurred. Concerning forced labor for public purposes, Oldham raised a concern that African's should fall under the exemptions to the ordinance if they were laboring on their own individual plots. ${ }^{200}$ The implication being that African work on their individual plots was not labor. He also restated his opposition to women working away from their homes overnight.

\footnotetext{
${ }^{198}$ Ibid.

${ }^{199}$ Ibid.
}

${ }^{200}$ On 27 October in the House of Commons the Under Secretary, Amery, had taken the erroneous position that African's could gain exemption to coerced labor for public purposes if they labored on their own individual plots of land. However, a letter from O. F. Watkins to Archdeacon Owen on 29 March 1921 stated that it would be impossible for the administration in Kenya to assess exemptions of Africans working on their own land. Watkins to Owens, 29 March 1921, File: "Forced Labor, 1920-27," Owen unofficial Papers, CMS, University of Birmingham, Birmingham. 
Oldham reiterated his call for a royal commission to further explore the larger issue of policy regarding Africa. Oldham's memorandum was more clearly a critique from within. As he stated, his position was

... not made in any spirit of hostility either to the government or the European community in in East Africa. On the fundamental principles of British rule over politically backward peoples there is no disagreement between the government and the signatories to the memorandum presented to Lord Milner. ${ }^{201}$

in essence, Oldham was calling on the $\mathrm{CO}$ to adhere to its mission civilatrice in Africa. The principle of trusteeship, according to Oldham, was being sacrificed through the rapid exploitation of African resources. ${ }^{202}$ For Oldham, Britain's duty towards the Africans could best be adhered to through a policy of African education and securing adequate land through the reserves. Through education, African's could be taught to better manage their agricultural practices and ultimately become "... more contented and more appreciative of the benefits of British rule." ${ }^{203}$

Unfortunately for Oldham, as one of the permanent officials in the CO, Bottomley, minuted, "as far as I am aware there is no one here who regards a Royal Commission as a satisfactory way of solving this difficulty." ${ }^{204}$ Neither Milner nor his successor Churchill were enthusiastic about 533/272.

${ }^{201}$ Memorandum on Native Affairs in the East African Protectorates, 17 May 1921, CO

${ }^{202}$ Reflective, perhaps, of the organizations past, Harris of the ASAPS saw a declaration of African property rights as the central issue where as Oldham emphasized trusteeship. Harris to Basil Mathews, 11 July 1921, Box G/141, BFASS/APS, Rhodes House Library, Oxford.

${ }^{203}$ Memorandum on Native Affairs in the East African Protectorates, 17 May 1921, $\mathrm{CO} / 533 / 272$.

${ }^{204}$ Minute Bottomley, 8 June 1921, Co 533/272. 
garnering the attention of a royal commission of enquiry.

Lord Milner surprised Oldham and his humanitarian cohorts by resigning in February 1921 leaving the way open for an apparent change in colonial policy. ${ }^{205}$ The new Secretary of State, Winston Churchill, was deemed to be more sympathetic to the post war ideals enshrined in the League of Nations. ${ }^{206}$ Churchill was familiar with Kenya, having traveled there during his earlier tenure as Under Secretary in 1907. His new Under Secretary, E. F. L. Wood was sympathetic to the humanitarian position since he had actually signed Oldham's memorandum, "Native Labour In East Africa and the Principle of Trusteeship." Oldham, despite his personal distaste for Churchill, hoped that he could be turned towards the idea of a Royal Commission of East Africa. Oldham wrote to Churchill's new under Secretary, Wood, restating his previous proposals to Milner calling for a royal commission. ${ }^{207} \mathrm{He}$ added that the main intent was to square events in Kenya with the purpose of trusteeship. The Colonial Office also received a letter from Frank Weston, the Bishop of Zanzibar originally addressed to the MP W. OrmsbyGore. Ormsby-Gore forwarded the letter to the CO. Although Weston's main intent was to obtain statistical information on clove production in Zanzibar his letter touched upon a number of related subjects. Concerning the labor issue in Kenya, he called on the new administration in the Colonial Office to end all forms of forced labor with the notable exception of forced labor for

\footnotetext{
${ }^{205}$ Milner's resignation had nothing to do with the forced labor controversy in colonial Kenya.

${ }^{206}$ Clayton and Savage, Government and Labour in East Africa, 117. The specific ideal I am alluding to is trusteeship.

${ }^{207}$ Oldham to Major Wood, 24 May 1921, IMC/CBMS, Box 238, File: Government Schemes, SOAS, London.
} 
communal purposes. ${ }^{208}$

The CO under Churchill, in particular his Under Secretary of State for the Colonies, E. F. L. Wood, proved more than compliant in dealing with Oldham. By June, Wood had met with Ainsworth. Following this meeting, Wood submitted Ainsworth's draft circular on his comments on Leys memorandum. The compilation of a new policy was in the works.

On 11 August E. Wood, sent a draft despatch entitled "Native Labour in East Africa" to Oldham and the Archbishop. ${ }^{209}$ The draft outlined Churchill's main points concerning the forced labor issue in Kenya. In the draft memorandum there was no objection to traditional unpaid labor or communal labor since it was deemed in the interests of the Africans involved. Encouragement of labor for private individuals was to only be in the form of educating Africans in the habits of industry but no facilitation of labor. Compulsory paid labor for government purposes was to be only used in cases of absolute necessity. In this regard, legislation supporting government forced labor should remain on the statutes unchanged. However, with the exception of porterage and servants on tour, government officials had to ask the $\mathrm{S}$ of $\mathrm{S}$ for approval before requisitioning paid forced labor for government projects. The draft memorandum also added that public works that require forced labor must be defined in the local legislation.

Oldham replied to Wood's proposal on 15 August after having consulted Archdeacon Owen and H. D. Hooper of the CMS in Kenya, Dr. Arthur and Reverend J. N. Olgivie of the Church of Scotland Mission. Although he agreed with the "spirit and intent" of the new policy, he had reservations about some aspects of the draft memorandum. Concerning traditional unpaid labor

\footnotetext{
${ }^{208}$ Weston to Ormsby-Gore, 11 May 1921, CO 533/274.

${ }^{209}$ Wood to Oldham, 11 August 1921, Box 238, File: "Government Schemes," IMC/CBMS, SOAS, London.
} 
or communal labor Oldham viewed it as a "necessary evil" but one which was not desirable to retain due to the potential for abuses under the colonial chiefs. ${ }^{210}$ To support his case, Oldham followed the skew of the Bishop's Memorandum by stating that chiefs could not differentiate between an order and a wish and would force labor if given a writ of instruction. To support this claim, Oldham pointed out that Archdeacon Owen saw the African chiefs as the root of most of the problems regarding forced labor. Oldham also added that the 1912-13 Labour Commission actually criticized unpaid labor as unproductive since it inculcated a disdain for work among Africans and contributed to generational conflict between the youths and chiefs. Oldham only supported the unpaid government forced labor in cases of emergency and public work that was clearly defined.

In regard to labor for private employers, Oldham did not feel comfortable with the wording concerning government facilitation of information for potential employers. Oldham felt that the qualifying phrase "beyond taking steps to put in touch with one another the employers of labour and the native who wishes to find employment" subjected the government officer to pressure to induce labor. ${ }^{211}$

Beyond these specific criticism Oldham went farther and broached the subject of trusteeship. ${ }^{212} \mathrm{He}$ called for a clarification of policy regarding paramountcy of the different racial

\footnotetext{
${ }^{210}$ Oldham to Major Wood, 15 August 1921, Box 238, File: Colonial Office," IMC/CBMS, SOAS, London.

${ }^{211}$ Ibid.

${ }^{212}$ It is interesting to note, perhaps as a reflection of the Society's past, that whereas Oldham stressed trusteeship, Harris, of the ASAPS, felt that an important issue in the Northey Circular fiasco was the attempt by the state and settlers to declare "a property right in Africans." Harris to Basil Mathews, 11 July 1921, BFASS/APS, Box G 141, "British East Africa, Forced Labour Land," Rhodes House Library, Oxford.
} 
groups: African, European and Asian. To decipher the issue of paramountcy, Oldham, again, called for a royal commission to address the problem of African education and to ascertain ways of gaging African opinion. Oldham ended his letter by emphasizing that his criticisms were more of a call for rehabilitation as opposed to being radical denunciations. ${ }^{213}$

Wood replied to Oldham's letter on 19 August. During the interim, Churchill met with Northey and Robert Coryndon to clarify the Colonial Office position on coerced labor. Coryndon, at the time, was governor of Uganda and would later become governor of Kenya until his untimely death in 1925. In the meeting in August with Northey and Sir Robert Coryndon, Churchill went over some of the main points that would underpin the draft despatch. Their conclusions in regards to government forced labor were significant. Concerning traditional unpaid labor, it was decided that no objection should be raised to this form of coercion. ${ }^{214}$ Government forced labor for state purposes was seen as a necessary evil that hopefully would be phased out. It was also agreed that the definition of permissible works of a public nature precluded work that was contracted through a private contractor. This specific issue would arise later in a later forced labor controversy in 1925 involving the Uasin Gishu railway extension. This draft proposal was then later shown to Oldham and the Archbishop of Canterbury for further appraisal.

Of note, this meeting with Northey and Coryndon had actually followed on the heels of an earlier meeting in June with John Ainsworth. On 4 June Ainsworth met with E. F. L. Wood to discuss the problems regarding the Northey circular. In the meeting Ainsworth stated that the

\footnotetext{
${ }^{213}$ Oldham to Major Wood, 15 August 1921, CO 533/274.

214“Native Labour in East Africa,” 17 August 1920, CO 533/270.
} 
main problem with the Northey labor circular was its coincidence with the new amendment for compulsory labor for government purposes in 1920. This, according to Ainsworth, caused confusion in the minds of chiefs who could not distinguish between compulsion for government work and encouragement for normal work. In contrast to Northey's stance in his meeting with Churchill, Ainsworth called for the abolition of all forced labor with the striking exception of communal forced labor. ${ }^{215}$ Since the CO was waiting for a report from Northey on this issue, no action was taken on Ainsworth's proposal. However, Ainsworth's draft circular and the meeting with Northey show that the $\mathrm{CO}$ was not contemplating the abolishment of communal labor.

Wood replied to Oldham on 19 August. Regarding communal labor, he stated that the CO could not contemplate its abortion for three reasons. First of all, according to Wood, it was an entirely different form of labor than government forced labor for public purposes and it had been in use for a long time. Secondly, Wood noted that communal labor was thoroughly understood by Africans and added that the Bishop of Zanzibar did not object to the premise behind communal labor that Africans should be responsible for the upkeep of roads in their areas. ${ }^{216}$ As he stated, "this form of labour which is traditional among natives in East Africa, is not, in my opinion, open to criticism, provided that such labour is confined to males and other limitations imposed by the ordinance are strictly observed; and I do not propose that any alteration be made." 217 Wood also added that, by way of his conversation with Northey, many of the abuses

215“"Draft of proposed Circular dealing with the question of Native Labour in Kenya Colony and Protectorate," 4 June 1921, CO 533/273.

${ }^{216}$ Wood to Oldham, 19 August 1921, Box 238, File: "Colonial Office," IMC/CBMS, SOAS, London.

${ }^{217}$ Ibid. 
under forced labor could be addressed if the missionaries or other bodies would furnish names and dates.

Wood stated that he did not feel that the government's role as a facilitator of labor through information would add any pressure for compulsion. However, he did offer to change the wording on the draft despatch from "to put in touch with ..." to "place at the disposal of the native any information ..."218 Pertaining to Oldham's call for African education, Wood stated that it was supported in spirit but was not fiscally possible. He then informed Oldham that Churchill would be sending the Despatch to the administration in Kenya soon.

Oldham responded on 23 August that "we are entirely satisfied with the main line of the proposed policy . . ." but disappointed with the CO's stance on traditional forced labor. ${ }^{219}$ Essentially Oldham's pressure had resulted in a change in wording. But did this indicate a change in policy? Oldham was one of the few humanitarians to criticize communal labor, but it was never with the same force of the campaign against forced labor for private purposes. Churchill retained acceptance of communal labor, but significantly, as Wood stated in his letter to Oldham on the 19 August, the justification was that it was a continuation of traditional duties and to support this contention reference was made to a supportive voice from the missionary sector.

Churchill released his despatch to the administration on 5 September of 1921. In his communique Churchill upheld the principle of forced labor for government purposes but with

${ }^{218}$ Ibid.

${ }^{219}$ Oldham to Wood, 23 August 1921, Box 238, File: "Colonial Office," IMC/CBMS, SOAS, London. 
certain limitations. ${ }^{220}$ Except for porterage, forced labor for government purposes could only be used for essential activities. Furthermore, the colonial government in Kenya would have to seek the CO's permission before using compulsory labor for government purposes. ${ }^{221}$ In addition, the colonial state could only "Encourage" African labor for private purposes through "facilitation" but not actual engagement in the procurement process of labor recruitment. ${ }^{222}$ This new change in colonial policy did not affect unpaid forced labor for traditional purposes, however. ${ }^{223}$

The crisis had been surmounted. The definition of acceptable forced labor practice had been narrowed. Forced labor for private purposes was excised officially according to Churchill's despatch. Essentially, this represented a "victory" for both the humanitarian lobby and the CO. As Edward Wood would gloat in a letter to Northey, "I think you will agree that we have reached satisfactory solution of this question in which we may hope to have the missionary societies and their friends with us instead of against us." ${ }^{224}$ Along these lines, G. Manley, the Secretary of the CMS, wrote to Oldham "that the Committee have heard with satisfaction of the recent despatch issued by the Secretary of State for the Colonies ... and record their thankfulness at this happy result, largely due to negotiations with the government carried on through the Conference of

\footnotetext{
${ }^{220}$ Great Britain, Despatch to the Officer Administering the Government of Kenya Colony and Protectorate Relating to Native Labour, Cmd. 1509, (September 1921).

${ }^{221}$ Clayton and Savage, Government and Labor in Kenya 1895-1963, 117.

${ }^{222}$ In theory, this meant that the state in Kenya was to provide information for prospective employers as opposed to actually procuring the labor for them.
}

${ }^{223}$ Maxon, Struggle for Kenya, 197. This traditional unpaid labor was sanctioned under the 1912 Native Authority Ordinance and allowed a colonial chief or headman to call up labor for up to 24 days a year for duties which were considered part of the traditional duties a member of a community would have to render in the interests of the community anyway such as upkeep of roads and clearing waterway.

${ }^{224}$ Wood to Edward Northey, 25 August 1921, CO 533/274.

Page -231- 
British Missionary Societies.”225

Manley might have overstated the importance of the Oldham and the Conference of Missionary Societies. Before acting on the forced labor issue the CO consulted its own officials first. However, the humanitarian impact did effect the way the $\mathrm{CO}$ responded to forced labor issue. The emancipatory discourse of free labor was the apogee of an Enlightenment belief in progress which universalized the ideals of freedom and individuality. ${ }^{226}$ Northey's circular represented a policy, forced labor for private purposes, that had been supposedly eschewed since 1834. Forced labor for private purposes was likened to pre-capitalist forms of labor organization such as slavery by the humanitarian lobby, consequently, it was labeled the antonym of progress and, therefore, had to be excluded. Colonization rested upon the idea of Africans accruing the benefits of capitalism through wage labor. Forced labor for private purposes contradicted the rhetoric concerning the beneficial effects of wage labor associated with capitalist progress. ${ }^{27}$ Milner's revised circular did not go far enough in disassociating the state from forced labor for private purposes. The response from the $\mathrm{CO}$, though, was in some sense, as Milner stated

${ }^{225}$ G. T. Manley to Oldham, 16 November 1921, G3 A5 letterbox 11, CMS Archives, University of Birmingham, Birmingham.

${ }^{226}$ Alice Conklin, "Colonialism and Human Rights, A contradiction in Terms? The Case of France and West Africa, 1895-1914," American Historical Review 103(2) 1998, 422; James Walvin, Questioning Slavery(London and New York: Routledge, 1996), 162; Gyan Prakash, "Colonialism, Capitalism and the Discourse of Freedom," in Shahid Amin and Marcel Van de Linde, eds., Peripheral Labor Studies in the History of Partial

Proletarianization(Cambridge: Press Syndicate of the University of Cambridge, ), 10; Frederick Cooper and Anne Stoler, eds., Tensions of Empire: Colonial Culture in a Bourgeoisie World(Berkeley, University of California Press, 1997), 1.

${ }^{227}$ Some humanitarian groups particularly the Anti-Slavery and Aborigines Protection Society, saw land ownership, free labor and respect for contractual principles as integral components of the mission civilatrice. Free labor would quell revolution and foster Western style development. Kevin Patrick Grant, "Uncivilized Savagery," 29 
himself, a reflection of the initial muted response to the Northey labor circular from the Bishops Memorandum. The Bishops Memorandum besides concurring that some form of coercion was necessary represented a religious sanction of Northey's labor policy from a pressure group within the protectorate. As Colonial Office official W. C. Bottomley would point out, acutely, of the Bishop's Memorandum "to a material extent it helps the Protectorate Government." 228

Under Churchill, however, the humanitarian criticisms of Oldham and the ASAPS were not as equivocal on the question of force and the individual as the Bishops Memorandum but were not as forceful in relation to the question of force and community. Consequently, forced labor for private purposes was completely disavowed, forced Labor for state purposes was curtailed and would be eventually discontinued as we shall see in the following chapter. However, communal labor, or unpaid forced labor for state purposes, on the other hand, remained in use until the end of colonial rule. In essence communal labor represented the limits of capital as it articulated with pre-capitalist forms in Kenya Colony. European capital in Kenya could not completely subjugate the pre-capitalist forms so, it used some categories of pre-capitalist labor obligations, such as communal labor, but recast the association. Forced labor for communal purposes, although, nominally, associated with pre-capitalist forms as traditional African duties owed to the chief, was co-opted and recast as an appendage of reforming capitalism in Kenya. ${ }^{229}$

Changes in government policy regarding government forced labor would have the effect ${ }^{230}$ of

${ }^{228}$ Minute by W. Cecil Bottomley, 17 June 1920, CO 533/242.

${ }^{229}$ Stichter, Migrant Labour, 37. Stichter states that forced labor in the service of peripheral capitalism resembled pre-capitalist labour which societies would normally give to a conquering nation, the so called tributary labor.

${ }^{230} \mathrm{I}$ am not inferring that humanitarian pressure directly lead to a change in colonial office policy. Instead, humanitarian pressure had the effect of creating a moral atmosphere. 
sanctioning forced labor for "communal" and state purposes. This reinforced the power of the normalizing state, as viewed from the metropole, while strengthening the power of the state built upon force in Kenya. So, while it seemed that the forced labor regime in colonial Kenya was being ameliorated, it was actually being intensified as the focus or justification for it shifted to customary law. ${ }^{231}$

${ }^{231}$ With the exception of Paul Zeleza and R. M. A. van Zwanenberg this point has not been adequately illuminated such scholars like Clayton and Savage, Government and labor in Kenya(London: Frank Cass, 1974); Sharon Stichter, Migrant Labor in Kenya: Capitalism and African Response(London: Longman, 1982); Marjorie Dilley, British Policy in Kenya Colony(New York: Barnes and Noble, 1966).; Raymond Buell, The Native Problem in Africa(New York: MacMillan Company, 1928).; Gaving Kitching, Class and Economic Change in Kenya(New Haven: Yale University Press, 1980). Zeleza, however, in his article "Labor Coercion and Migration," in Abebe Zageye and Shubi Shero, eds., Forced Labor and Migration(New York: Hans Zell Publishers, 1989) sees reduction in the abuses of forced labor as a reflection of the weaknesses of forced labor itself. Consequently, the colonial state came to disavow it. R. M. A. van Zwanenberg, Colonial Capitalism and Labor In Kenya(Nairobi: East African Literature Bureau, 1975) also unearthed the connection between the humanitarian agitation against the Northey Circulars and the subsequent emphasis by the colonial state upon communal labor following Churchill's labor despatch of 1921. But he sees the recourse to communal labor by the colonial state as a way of not raising eyebrows in the metropole since the use of communal labor did not require approval by the Secretary of State for the colonies. 


\section{Chapter 7}

\section{Further Labor Issues and the Normalization of Force}

The discourse over the Northey labor circular and the subsequent state response bounded forced labor for private purposes. It was deemed not acceptable. The Northey crises and the state response, by excluding government forced labor for private purposes, served to deflect attention away from the problems of government poverty and African labor. Following Churchill's despatch, the $\mathrm{CO}$ also gradually moved to curtail government forced labor for state purposes over the following decade. In 1924-25 Kenya disgorged another labor controversy. In this instance, the $\mathrm{CO}$ and the colonial state faced humanitarian protests over the use of force in recruiting labor for an extension of the Uganda railway. The controversy produced a communique from the Secretary of State for the Colonies, L. S. Amery, on 6 February 1925 to the Governor of Kenya, at the time, Sir Robert Coryndon, which further clarified the position of the CO concerning forced labor by the administration and adverted another labor crises. ${ }^{1}$ However, as we shall see, the discourse over the forced labor issue also resulted in the normalization of government forced labor for communal purposes.

The decade long campaign against communal labor by Archdeacon William Owen was a reminder of the necessity and intractability of communal forced labor despite the humanitarian "victory" in 1920-21. The CMS missionary was an ardent critic colonial policy in Kenya from his diocese in Western Kenya. Owen's criticisms of colonial policy were marked with ambiguity and contradiction, but his detailed investigations of forced communal labor laid bare some of the

${ }^{1}$ This despatch became Parliamentary Command Paper 2464 of July 1925. 
more heinous aspects of this form of forced labor and its entrenched nature within the political economy of Kenya. The process that had culminated in Churchill's despatch was an abstraction of the tensions of settler capital and African labor. Consequently, the result, the exclusion of government forced labor for private purposes, was at once a tacit acceptance of communal forced labor justified under the rubric of community.

\section{Aftermath of the Crisis}

All in all, humanitarians were pleased with the new government policy on forced labor. The climate following the despatch was a reflection of the prevalent sentiment that Churchill's despatch was a measure of progress. After publication of Churchill's despatch, the ASAPS wrote to Churchill congratulating the $\mathrm{CO}$ on the change in policy regarding forced labor. The Society also asked for a copy of draft of the proposed amending ordinance for government forced labor in order to make suggestions for future changes regarding government forced labor. ${ }^{2}$ There was some recrimination within the $\mathrm{CO}$; Bottomley, for instance, stated that "the Society are not nearly so moderate and judicial as Oldham and the Missionary Conference and I would keep them out of this if possible." ${ }^{3}$ Nevertheless, the CO relented and agreed to send the ASAPS the draft amending ordinance.

Besides the praise from the ASAPS, evidence from Kenya suggested that the state had turned the corner regarding forced labor as well. The annual report for the Kenya Native Affairs Department in 1921 offered statistical corroboration of declining upon government forced labor. The report indicated that the number of men called out for labor under the 1920 amendment to

${ }^{2}$ John Harris and Travers Buxton to Winston Churchill, 10 October 1921, CO 533/272.

${ }^{3}$ Minute By Bottomley, 14 October 1921, CO 533/272. 
the Native Authority ordinance, for government forced labor, had actually declined during $1921 .{ }^{4}$ In April, 1284 men were called out for an average of 22 days labor. By December the number of men called out had declined to 614 with an average of 10 labor days. Overall, for 1921, 6503 men were called out under the 1920 amendment with an average of 14 days worked. Most of the laborers were used as porters for administrative officials on tour. The administration, itself, employed most of the labor followed by the Public Works Department. A review of applications for labor under the Native Authority amendment of 1920 also showed that much of the labor was drawn from Nyanza Province and Kenia Province. ${ }^{5}$

The state was the largest single employer of Africans partly due to its reliance upon forced labor, paid and unpaid. The state used paid porterage extensively under the ordinance governing forced labor for state purposes. A summary of labor ordered out under the Native Authority Amendment of 1920 between 1924 and 1928 is illustrative. ${ }^{6}$ In 1924 the state called out 19,323 men for paid forced labor. Of this number, the administration was responsible for utilizing 14,281 men, mostly for porterage. This number gradually decreased. In 1928 the state only called out 12,897 men for paid forced labor. Again the administration was responsible for most of the men called out at 11,239. The administration in Kenya did not keep records on the number of men called out purely for unpaid communal services.

Although there was a decline in the number of men called out for government forced labor CO 533/282.

4“Native Affairs Department Report for April to December 1921,” 28 September 1922,

${ }^{5}$ Applications Under the Native Authority Amendment Ordinance 1920, 31 January 1921, CO 533/255. The area of Kenia province, specifically were the labor was drawn, would later become Kikuyu province.

${ }^{6}$ Colony and Protectorate of Kenya, Native Affairs Department Annual Report, 1926 (Nairobi: Government Press, 1927), 113 
between 1919 and 1921, this time period was also the beginning of increased surveillance of African labor. In November 1915 the Legislative Council in Kenya had passed legislation for a pass system of identification and registration. In 1921 the administration passed another amending ordinance to the 1915 legislation. This pass system of identification was used to identify Africans for the purposes of taxation, labor and statistics. Africans were required to wear a metal box that housed a piece of paper known as "kipande" that identified them and also gave information as to their work status. This system was designed to discipline the African labor force and intensify state control by limiting desertion. The efficacy of this pass system was borne out by the decrease in the number of deserters. According to the Native Affairs Department report for 1921, the number of desertions decreased from 1,228 out of 194,750 registered Africans in December 1920 to 516 out of 389,632 registered Africans in December 1921. ${ }^{7}$

Another outgrowth of the Northey forced labor crisis was the authorization of a Labour Bureau Commission in 1921 to look further into the labor problems in colonial Kenya. The publication of its report would also add to the climate of good feeling concerning forced labor.

In August 1920 at the height of the forced labor controversy, Northey was asked to comment on the workings of the 1920 amendment to the Native Authority ordinance and labor complaints by the Thika District Association in Kenya. Northey replied in January 1921 that the labor situation in Kenya had stabilized. ${ }^{8}$ Government departments had been instructed not to use the 1920 amendment as the primary means of recruiting labor. However, Northey anticipated future $533 / 282$.

${ }^{7}$ Native Affairs Department Report For April to December 1921, 28 December 1922, CO

${ }^{8}$ Northey to Milner, 31 January 1921, CO 533/255. 
labor shortages with the arrival of more European settlers. As a result, he proposed the formulation of a labor commission to look into the requirements of private employers regarding their labor force and the formulation of a labor bureau to govern African labor. The scope of the commission's investigation was also to include Africans laboring for government departments and would be chaired by the Chief Native Commissioner. Unlike the earlier 1912 Native Labour Commission, however, the 1921 labour commission consisted primarily of representatives of the government, European settlers, missionaries and labor agents. All of the five Africans who served as witnesses were also employed by the administration as chiefs and headmen. Some notable members of the commission included William McGregor Ross, Director of Public Works in Kenya and critic of the administration, and Oscar Watkins, the Acting Chief Native Commissioner.

The Commission concluded in its findings that there would be a labor shortage of about 32,000 men from 1922 onwards. ${ }^{9}$ To remedy the potential shortage of labor, the commission, surprisingly, recommended against a labor bureau. Instead the commission opted for increasing African labor efficiency. This, in essence, meant substituting machinery for labor power, more strict enforcement of the Resident Natives Ordinance, appointment of recruiting agents for government departments under the control of the Chief Native Commissioner and stricter supervision of professional labor recruiters. The Commission concluded its recommendations by emphasizing that labor must be "free and unforced" and it stated that no administrative officer should be involved in recruiting.

The commission's findings were well received in the CO. They reflected the climate of amelioration that existed in the wake of the Northey crisis. The commission had consulted the

\footnotetext{
${ }^{9}$ Report of the Labour Bureau Commission, 11 March 1922, CO 533/278.
} 
findings of the 1912 Native Labour Commission and consequently was able to steer clear of potential political footfalls. Northey, for his part, agreed with most of the findings of the Commission with some exceptions. He did not like the idea of having recruiting agents under the authority of the Chief Native Commissioner and thought the figure for potential labor needs too high. The S of S agreed with Northey's slight objections and the report was given a stamp of approval. $^{10}$

Despite the ameliorative atmosphere surrounding forced labor, a test case of colonial policy was on the horizon. In early 1925 another labor controversy erupted. This labor controversy resulted in a further despatch from the $\mathrm{CO}$ curtailing government forced labor, in principle, and effectively ended the use of this form of forced labor during peace time. Although this episode of government forced labor never became as big an issue as the Northey crises, it was significant in one respect. It represented the culmination of the abstraction of the contradictions of colonial rule and African labor. Churchill's despatch in 1921 decreed guidelines for the rejection of government forced labor for private purposes but also for the normalization of government forced labor. The colonial state would have to seek permission from the $\mathrm{S}$ of $\mathrm{S}$ before calling out government forced labor for state purposes. In the 1925 forced labor crisis the $\mathrm{CO}$ and the administration in Kenya moved fast to ensure statutory safeguards for the curtailment of paid government forced labor so as to ward off another controversy. Building upon Churchill's despatch, in addition to having to gain the CO's permission, the state in Kenya would now be limited in the number of Africans they could call out for labor at one time. However, there would be no appropriate legislation regarding unpaid government forced labor or communal labor. And, as Archdeacon Owen's campaign against communal labor showed, resort to this

\footnotetext{
${ }^{10}$ Churchill to Northey, 24 May 1922, CO 533/278.
} 
form of government forced labor was quite entrenched in the colonial economy. The Northey crises and the Uganda railway forced labor issue of 1925 served to normalize the use of communal labor. The state responded as an institution amenable to its varied constituencies. The progressive state snuffed out government forced labor for private purposes and curtailed government forced labor for state purposes. Perhaps as a reflection of the political economy of Kenya, the question of communal labor was never seriously raised by humanitarians, with notable exceptions, and any way it was merely an extension of "tribal" duties.

This institutionalization of forced labor was quite evident, in the wake of Churchill's despatch in 1921. By this point, the $\mathrm{CO}$ was quite sensitive to the issue of forced labor in Kenya. They did not want another Northey forced labor scandal. To the chagrin of the CO; however, a labor situation arose in 1924 that would again expose the contradictions of colonial rule and African labor. In December 1924, a labor shortage developed during the construction of the Thika-Nyeri and Uasin Gishu extensions to the Uganda railway. In October one of the sub contractors involved in the railway construction, Griffiths Coy and Company, began to report that they were experiencing severe labor shortages. ${ }^{11}$ According to Griffiths and Coy, these labor shortages actually began in May but by October were becoming more severe. The representative of Griffiths and Coy affirmed, however, that the reason for the drop off was not due to mistreatment. As he stated, "railway work on the Uasin Gishu line has never been unpopular."12 Despite this "popularity" the company was not going to able to complete the railway by the deadline in September.

${ }^{11}$ Great Britain, Kenya, Compulsory Labour for Government Purposes, Cmd. 2464, (July 1925), 10-12.

${ }^{12}$ Ibid., 11. 
On 22 November the General Manager of the Thika Nyeri railway project wrote Sir Robert Coryndon, the governor of Kenya, informing him of labor shortages. He suggested that "the government should instruct the District Officers to make it known to the natives in their areas that labour is expected to come out for work on the railway construction."13

The administration responded. On 15 December 1924 Coryndon wrote the $\mathrm{S}$ of $\mathrm{S}$ requesting permission to coerce labor for railway construction. With reference to the Native Authority Amendment Ordinance 1922, Coryndon justified his action in the interests of "urgent public importance." Coryndon assured the CO that he would use every possible means to garner labor voluntarily. ${ }^{14} \mathrm{He}$ added that he would keep the $\mathrm{CO}$ informed as to the wages, the number of men employed, nature of the work and the period of time the men would be forced to labor.

Coryndon wrote again to the Under Secretary of State, W. Ormsby-Gore ${ }^{15}$ requesting approval to requisition forced labor for railway construction on 28 December. ${ }^{16}$ Coryndon argued that cotton and coffee crops from Uganda and Kenya would be lost unless the railway extensions were completed. He added, however, that the wages of the men were also to be lower than the regular market wages of voluntary African labor in the surrounding area of railway construction. A preceding letter to the S of S, L. S. Amery, by the British East Africa Fibre and Industrial Company better explains the reasoning behind the stipulation for African lower

\footnotetext{
${ }^{13}$ Ibid., 12.

${ }^{14}$ Ibid., 10.
}

${ }^{15}$ Ormsby Gore (1885-1964) was a Conservative MP, a supporter of mandates having served on the Mandates Commission. He would later become S of S for the colonies from 1936 to 1938 . He also led the East Africa Commission on Closer Union in 1924 under the S of S Amery.

\footnotetext{
${ }^{16}$ Robert Coryndon to Orsmby-Gore, 28 December 1924, CO 533/325.
} 
wages. The company, like Griffiths and Coy, wrote complaining about a shortage of labor. In this case, a dearth of workers for their cotton plantations. It placed the blame on the administration, complaining that railway workers were receiving higher wages than the market value $^{17}$ Consequently, the cotton growers were not able to attract African laborers with the inducement of lower wages.

To procure labor initially, Coryndon passed a labor circular designed to "encourage native labour to come out voluntarily for all work of public utility."18 Coryndon emphasized that the circular was intended not to "secure or suggest compulsory labor." 19 The actual circular called for barazas or meetings in targeted areas between chiefs and government officials. At these meetings the circular stated "that the government wishes all administrative officers and native official headmen to facilitate the voluntary flow of labor to railways, public works or works of other economic importance." 20

Although the circular was regarded as unobjectionable within the $\mathrm{CO}$, due to the recent scandal over the Northey circular, it was not without some concerns. As Bottomley minuted, "I think it will stand criterion, but if, as we are told, the headman regards government writs as an order, the district officer who encourages will possibly also have to restrain undue pressure. We must have the experiment to prove itself." 21

The experiment would prove itself soon enough. The initial circular encouraging African

\footnotetext{
${ }^{17}$ F. Johnson to L. S. Amery, 19 November 1924, Co 533/324.

${ }^{18}$ Coryndon to L. S. Amery, 8 January 1925, CO 533/328.

${ }^{19}$ Ibid.

${ }^{20}$ Circular No. 49, Native Affairs Department, 22 December 1924, CO 533/328.

${ }^{21}$ Minute by W. Bottomley, 9 February 1925, CO 533/328.
} 
labor was not effective. On 9 January 1925 Coryndon telegraphed Amery with an urgent request to garner compulsory labor not only for the railway extension but also for handling and ordinary railway traffic at Kisumu docks on Lake Victoria and for public works in general. ${ }^{22}$ The governor asserted that, later reports from DCs about the efficacy of the circular, for the most part, reported lack luster African turn out. ${ }^{23}$ In Nyanza province, DCs reported that the districts were almost at capacity in terms of labor supply and could not supply more. ${ }^{24}$ In Kikuyu Province the response was mixed. However, in Ukamba Province most of the DCs found that the Kamba were resistant to the notion of laboring out of the reserve. Consequently, most of the replies within Ukamba Province called for compulsory measures. ${ }^{25}$

The response within the $\mathrm{CO}$ to Coryndon's latest request was measured anxiety. Although Coryndon's request for labor on the railway was regarded as satisfactory, there was concern that Coryndon's more general request for public works went beyond the definitions set forth in Milner's earlier despatch concerning works of a public nature where forced labor could be used. ${ }^{26}$ Moreover, harkening back to eh Northey controversy there was a fear that some of the forced labor on the railway line would actually be used by subcontractors.

Consequently, Amery replied in a telegram on 14 January and a further despatch on 6 February 1925 adding further guidelines for the use of government forced labor. Amery's response and other papers would eventually become a Parliamentary command paper in July

\footnotetext{
${ }^{22}$ Coryndon to Amery, Telegraph, Urgent, 9 January 1925, CO 533/328.

${ }^{23}$ Precis of Replies to N. A. D. Confidential Circular No. 49/25, 1 September 1925, CO $533 / 333$.

${ }^{24} \mathrm{Ibid}$.

${ }^{25}$ Ibid.

${ }^{26}$ Minute by Bottomley, 9 January 1925, CO 533/328.
} 
1925 and marked the denouement of colonial policy relating to government forced labor.

Amery's telegraph on 14 January denied Coryndon's request for general use of government forced labor. ${ }^{27}$ Amery stated that forced labor could only be used for specific projects. As a result, the request for forced labor on the railway extensions was approved but only up to a limit of 4,000 men per request. Labor for the Kisumu docks was denied.

The despatch on 6 February upheld the principles of Churchill's earlier despatch and added that compulsory labor for government purposes could only be used if the Africans understood the social utility of their compulsion to work. ${ }^{28}$ Amery was aware of the problems this presented, for he added that, "from this aspect, the case of the African native presents much difficulty." 29 The $\mathrm{S}$ of S made it clear that due to the controversy surrounding the Northey Circular compulsory labor could only be sanctioned for specific duties recognized as public utility under Milner's despatch..$^{30}$ Amery also reaffirmed the official opposition to forced labor for private individuals:

As stated in Lord Milner's despatch of the $22^{\text {nd }}$ of July 1920, the provision of compulsory labour for private employers is absolutely opposed to traditional policy of His Majesty's Government, and I should be disposed to regard in the same light any proposal to utilise such labour for government purposes otherwise than as indicated in the despatch of the $5^{\text {th }}$ of September $1921 .^{31}$

In continuation, Amery pointed out that any extended use of compulsory labor beyond the guidelines of the despatches would be difficult to reconcile with the ideals of trusteeship. The $\mathrm{S}$ of $\mathrm{S}$ also added that he hoped the men chosen for compulsory labor were men that had neither

\footnotetext{
${ }^{27}$ Amery to Coryndon, Telegram, 14 January 1925, CO 533/328.

${ }^{28}$ Amery to Coryndon, 6 February 1925, CO 533/328.

${ }^{29}$ Ibid.

${ }^{30}$ Ibid.

${ }^{31}$ Ibid.
} 
worked for wages nor produced any cash crops for sale. This latter statement was a recognition within the $\mathrm{CO}$ that Africans who worked on their individual plots as cash crop producers should be exempt from forced labor. ${ }^{32}$ However, it was also an affirmation that Africans who worked on plots for their own food were defined by the state as "non workers." ${ }^{33}$ The reasons for this were obvious. Africans who worked on their own plots for household production were not contributing directly for accumulation on behalf of the state or the European settlers. Amery concluded his remarks by emphasizing that forced labor was inefficient, anyway, in comparison to free labor, and, as such, the standard of work is always inferior. Forced labor appeared oppressive to Africans, according to Amery, and this outweighed any perceived educative influence of forced labor. Amery's positions were a change from his earlier views when he was Under Secretary of State for the Colonies.

Coryndon was partially rebuffed, but on 23 January 1925 he telegraphed the CO with details of the pay scale that would be offered for the coerced African railway laborers. Coerced railway workers were to receive 2 shillings less per month than voluntary workers. The CO criticized this differential pay scale. As the Colonial Office official, H. Lambert minuted, "I cannot see how a lower rate than ordinary market rate can be possibly defended and if the papers are ever published the House of Commons will presumably want to know what 'lesson' was to be taught." ${ }^{34}$ The fear was that the differential pay scale would be employed as a method of keeping

\footnotetext{
${ }^{32}$ Minute By Bottomley, 2 February 1925, CO 533/328. This hope or suggestion was a change, for previously Africans who had worked on their own plots were effectively liable for forced labor duties.

${ }^{33}$ Minute by Bottomley, 29 April 1925, CO 533/330.

${ }^{34}$ Minute by Henry Lambert, 28 January 1925, CO 533/328.
} 
wages down in the general labor market. ${ }^{35}$ Coryndon also added that the forced laborers would only come from the ranks of non workers.

Amery's reply on 30 January emphasized that the CO had "strong objection in principle" to Coryndon's proposal regarding wages for compulsory labor. ${ }^{36}$ Amery also made it clear that recruitment of coerced laborers could not be put in the hands of the sub-contractors working on the railway. Amery raised other points concerning the labor situation and asked Coryndon to send a despatch containing more information on the demands of labor for public works.

Before Coryndon sent his despatch, he died unexpectedly on 10 February 1925. On 12 February Acting Governor A. G. Denham sent a telegram to the CO further explicating the wage issue relating to the coerced laborers on the railway extension project. Denham stated that the reduced wages for the compulsory labor were to induce Africans to seek voluntary wage employment. As he stated, "it is desirable that the natives should feel that they are gaining more by offering their services for employment than by awaiting compulsion." 37 He also assured the $\mathrm{CO}$ that the reduced rate of pay for the coerced laborers would not go below 8 to 10 shillings a month which was the average market rate for farm labor. ${ }^{38}$ In addition, Denham pointed out that the wages for railway workers also "included the benefit of special railway rations." ${ }^{39}$

Within the CO, officials were most concerned that if the papers associated with this issue were published, as they were at a later date, the perception would be that the lower wages were

\footnotetext{
${ }^{35}$ Minute by Henry Lambert, 27 January 1925, CO 533/328.

${ }^{36}$ Amery to Coryndon, 30 January 1925, CO 533/328.

${ }^{37}$ Denham to Secretary of State for the Colonies, telegram, 12 February 1925, CO
} $533 / 329$.

\footnotetext{
${ }^{38}$ Ibid.

${ }^{39}$ Ibid.
} 
punitive measures that penalized Africans who were tilling their own plots by pushing them to "make the white man's railway." ${ }^{40}$ Consequently, it was decided that the pay for the coerced laborers should not be greater than 2 shillings below the regular pay for voluntary workers. In addition, it was agreed that the distinction in pay was to be based upon the status nonexperienced coerced laborers versus experienced voluntary laborers. ${ }^{41}$ On 20 February 1925 , Amery telegraphed Denham approving the wage scale difference provided it did not exceed 2 shillings per month. ${ }^{42}$ Amery also asked Denham to submit monthly reports regarding the numbers of men coerced, their pay and the medical conditions on the railway construction.

The colonial state then issued the circular governing forced labor for the railway on 20 February. With reference to the Native Authority Amendment Ordinance 1922, the circular defined the duration of work as 60 days. ${ }^{43}$ The period of employment would begin from the day men actually started work as opposed to when they actually first left their homes to travel to the worksite. DCs were instructed to make sure that the 60 day period was not exceeded and to not call out any men who qualified for exemption under the Native Authority Amendment Ordinance. ${ }^{44}$ They were also instructed to maintain lists of men who had been called out indicating their names, registration mumbers and the period of time they were to work.

On 12 March Denham sent a telegram to Amery detailing the amount of coerced labor called

${ }^{40}$ Minute by H. Lambert, 18 February 1925, CO 533/329.

${ }^{41}$ Minute by W. Ormsby-Gore, 19 February 1925, CO 533/329.

${ }^{42}$ Amery to Officer Administering the Government of Kenya, Telegram, 20 February 1925, CO 533/329.

${ }^{43}$ Instructions Governing the Employment of Labour Ordered Out to Work Under the Native Authority Amendment Ordinance, 20 February 1925, Daily Correspondence Nyanza Province, 1908-193, Deposit 1 Box 12, Kenya National Archives, Syracuse University.

${ }^{44}$ Ibid. 
out and also requesting powers to force more laborers to work. Denham stated that 1200

Africans had been called out for labor mostly from among the Luyia peoples and 300 from Kerio province. ${ }^{45}$ Denham requested permission to call out 700 more Africans mainly from the Kamba ethnic group. He felt that they were not contributing enough men to the labor market. There was some question within the $\mathrm{CO}$ concerning the use of Africans from Kerio province on the Uasin Gishu railway since it was approximately 40 miles from their home area ${ }^{46}$ However, Amery gave approval for the coercion of $700 \mathrm{Kamba} .{ }^{47}$

In accordance with Coryndon's original instructions from the CO, Denham sent a despatch to Amery on 14 March reporting on the status of forced labor and the railway construction.

Denham mentioned that he was in the process of appointing an administrative official to oversee recruitment and care of railway laborers. Up to 9 March, Denham reported that 442 compulsory and 108 voluntary workers had been despatched to work on the railway. ${ }^{48}$ He added that the specter of compulsion pushed many Africans to seek wage employment. On 17 April Denham wrote the S of S adjusting the numbers of Africans called out for labor. According to Denham, the total number of compulsory labor called out for March was 1,561 for the Uasin Gishu and 59 for Thika-Nyeri extensions. ${ }^{49}$

Denham also reported on the casualties associated with the railway construction. The death

${ }^{45}$ Denham to Secretary of State for the Colonies, Telegram, 12 March 1925, CO 533/330.

${ }^{46}$ Minute by Bottomley, 17 March 1925, CO 533/330.

${ }^{47}$ Amery to Officer Administrating the Government of Kenya, Telegram, 7 April 1925, CO 533/330.

\footnotetext{
${ }^{48}$ Kenya, Forced Labour for Government Purposes, 20.

${ }^{49}$ Ibid., 24.
} 
rate for compulsory labor in March was one in $1,561 .{ }^{50}$ The medical condition of both the compulsory laborers was deemed satisfactory. During March, however, 55 compulsory workers and 48 voluntary workers were admitted into the hospital. Most of the afflicted workers suffered from bronchitis, influenza and malaria. ${ }^{51}$

Within Kenya, although some officials, as was the case in Ukamba Province, welcomed the promulgation of force, others were skeptical about the timing of the forced labor circular. D. R. Crampton, DC for South Kavirondo District within Nyanza Province, criticized the enactment of the circular as too abrupt. ${ }^{52}$ Crampton stated that the Africans and the administrative staff needed at least a one month notice to avoid the typical abuses associated with labor recruitment. ${ }^{53}$ Moreover, Crampton added that Africans were not aware that, during the period when the state was calling for voluntary labor, coercion would follow if they did not turn out for labor.

Internally, compulsory work on the railroads was regarded as extremely odious to most Africans. ${ }^{54}$ One DC even complained about the diversion of a compulsory labor gang to contract work for Europeans. For example, Luo who had been sent into Kisii to await government orders for compulsory labor on the railway were intercepted by a private labor recruiter who then sent them to Kisumu for contract work. ${ }^{55}$ The Africans preferred the contract work over the railway

${ }^{50}$ Ibid.

${ }^{51}$ Ibid., 28.

${ }^{52}$ D. Crampton to the Senior Commisioner, Nyanza Province, 9 February 1925, Daily Correspondence Nyanza Province, 1908-1930, Deposit 1 Box 12, KNA, Syracuse University, Syracuse.

${ }^{53}$ Ibid.

${ }^{54}$ Ibid.

${ }^{55}$ W. Slade Hawkins to Senior Commissioner, Nyanza, 7 March 1925, Daily Correspondence Nyanza Province, 1908-1930, Deposit 1 Box 12, KNA, Syracuse University, Page -250- 
work.

Despite this muted internal dissent, Denham pressed on for the coercion of African labor. On 20 May 1925, he telegraphed Amery with a request for clarification on his powers of recruitment of government forced labor that were issued while Coryndon was still governor. Denham inquired whether he could recruit labor up to the maximum of 4000 men without $\mathrm{CO}$ approval, or whether $\mathrm{CO}$ approval was required each time he desired to recruit compulsory labor for government services. ${ }^{56}$ The response within the $\mathrm{CO}$ was conclusive but revealing. As Bottomley minuted "in view of the parliamentary attacks it seems desirable to go slowly." ${ }^{57}$ The reason for Bottomley's stance lay, in the fact that, by May, MPs within the House of Commons were beginning to question Amery about the use of forced labor on the Uasin Gishu railway extension. Consequently, Bottomley proposed that the telegram to Denham should make it clear that "there would be no question of anything like the total number of 4000 having to be called out." ${ }^{\prime 58}$ The subsequent telegram to the acting governor on 3 June reiterated that Denham should never come close to requisitioning 4000 men, and he needed to gain the S of S's approval for recruitment of forced labor for government projects. ${ }^{59}$ Despite these explicit instructions meant to curtail government forced labor Denham would embarrass the $\mathrm{CO}$ at a speech addressing the Convention of Associations.

On 9 March Denham delivered a surprising and controversial speech to the Convention of

Syracuse.

${ }^{56}$ Denham to Secretary of State for the Colonies, Telegram, 20 May 1925, CO 533/331.

${ }^{57}$ Minute by Bottomley, 22 May 1925, CO 533/331.

${ }^{58}$ Ibid.

${ }^{59}$ Amery to Denham, Telegram, 3 June 1925, CO 533/331. 
Associations that caused a small ripple within the $\mathrm{CO}$, but it also further explicated the official view of African labor. During his speech at the opening session of the Convention of Associations, Denham stated "that government expects every administrative officer to give all possible encouragement to the labour within their district to work on the lands which have been opened up by the settlers of this country." ${ }^{60}$ Denham's speech was an attempt to assuage the settlers that despite the acclaimed policy of encouraging African production and settler production, the state was still sympathetic to settler demands. Essentially, as one of the CO official minuted, "Mr. Denham seems to have done his best to come down on both sides of the fence." ${ }^{61}$ Unfortunately for Denham, The Times selectively quoted from his speech and reported it gave support to the idea of government forcing African labor for the European settlers. In his explanation to Amery, Denham defended his speech by pointing out that the press report only excerpted parts of his speech. According to Denham, the gist of his speech to the Convention of Associations was an attempt to square the idea of Dual Policy with African production while not neglecting settler production. ${ }^{62}$ It was not to be construed as a departure from the policy laid down by Churchill's despatch that the state was not to force African labor for private interests . Denham believed that Africans could be encouraged to work on their farms in the reserves for some months of the year but during the period of harvest can then find opportunities to work for Europeans. $^{63}$

Within the CO, the consensus was that The Times article had omitted some crucial

\footnotetext{
60، The Acting Governor's Speech,” 9 March 1925, CO 533/330.

${ }^{61}$ Minute by C. Strachey, 1 May 1925, CO 533/330.

${ }^{62}$ Denham to Amery, 27 March 1925, CO 533/330.

${ }^{63}$ Ibid.
} 
information from the governor's speech, therefore, skewing the focus of his talk. ${ }^{64}$ However, Bottomley criticized Denham's speech for being to vague in regards to acceptable African production. As Bottomley minuted, acceptable African production, that should not be compromised by the dictates of wage labor for Europeans, was cash crop production. ${ }^{65}$ Africans who labored for their own usufruct were essentially "non workers" and should be culled out for labor for Europeans. ${ }^{66}$ This would not hinder African production, for the bottom line was that "it is extremely improbable that one say 'don't work for the whiteman'.,"67

In March, also, Dr. Norman Leys published a book entitled Kenya that was highly critical of colonial policy in Kenya. Leys' work touched upon a number of subjects. However, in contrast to his earlier criticisms of colonial labor policy during the Northey Crises, Leys' denunciations of forced labor would carry less weight within the CO in 1925. As mentioned previously, Leys sent memoranda to the $\mathrm{CO}$ during the Northey Circular crisis criticizing administrative policy and calling for the repeal of government forced labor. Though disparaging much of Leys' comments, Ainsworth had agreed with him on the issue of forced labor.

However, by 1925 four years after the passage of Churchill's despatch, the CO was quite dismissive of Leys perceptions of the labor issue as outdated. ${ }^{68}$ Leys criticized administrative labor policy as a mere device for supplying African workers for Europeans that further burdened women in the reserves by extracting able bodied African men. Denham's comments on his book

\footnotetext{
${ }^{64}$ Minute by Bottomley, 29 May 1925, CO 533/330.

${ }^{65}$ Ibid.

${ }^{66}$ Ibid.

${ }^{67}$ Ibid.

${ }^{68}$ Minute by W. Bottomley, 12 May 1925, CO 533/330.
} 
were reflective of the mood within the CO. As he stated, "in so far as Dr. Leys' criticisms are sound, they are mainly directed against a policy that he himself shows has largely ceased to exist. At any rate the criticism do not suggest any drastic deviations from policy." ${ }^{99}$

Leys condemnation of forced labor offers a striking parallel to his earlier criticism. His second criticism did not have the same weight precisely because the issue of forced labor was seen as surmounted. In some ways, Leys earlier criticism contributed to this institutionalization of forced labor. His earlier criticism forced the $\mathrm{CO}$ to compare his views with that of a respected administrative official, John Ainsworth. Their consensus on certain issues provided the basis for an eventual change in policy. By 1925 , however, the state had coopted the potentially weakening issue of forced labor. Leys condemnations were simply shouts in the dark against a system which, according to the $\mathrm{CO}$, had been excised.

As noted earlier, questions began to crop up in parliament concerning the use of forced labor on the Uasin Gishu railway project by May. On 18 May the MP P. J. H. Hannon asked Amery about the cost of the extension to the Uganda railway. ${ }^{70}$ Amery responded that the extension, including port development, cost 3,500,000 pounds. ${ }^{71}$ Afterwards another MP, H. Snell, asked Amery whether he had authorized the conscription of labor under the Native Authority Amendment Ordinance, $1922 .^{72}$ Snell also wanted to know whether the labor was recruited primarily in the reserves thus penalizing Africans who were not working for European planters. Amery admitted that he had given approval for the conscription. He also informed the House

\footnotetext{
${ }^{69}$ Denham to Amery, 27 March 1925, CO 533/330.

${ }^{70}$ Great Britain, Parliamentary Debates, Commons, $5^{\text {th }}$ Ser. V. 184 (1925), col. 12.

${ }^{71}$ Ibid.

${ }^{72}$ Ibid.
} 
that Africans under contract could not be conscripted for labor projects. ${ }^{73}$ Amery also stated that the number of conscripted Africans by March 1925 was 1,620 versus 11,099 free laborers. In light of Amery's statement, Snell asked if removing Africans from their own land was not detrimental to their own interests. Amery replied that it was not. With this seemingly new fact, a lot of the members seemed astounded and questioned Amery about penalties for non compliance with forced labor and other matters. For example, another MP, Johnston called for a discussion of African labor conscription at a later date.

The discussion continued on 25 May; several MPs questioned the S of S about the methods used in conscription of labor, the wages paid, the extent of the labor period, the numbers of Africans coerced for labor on the railways and the penalties for refusal. ${ }^{74}$ Initially Ormsby-Gore, the under secretary, replied that all of their answers would be found in the upcoming official report. However, he was shouted down with cries of "No, no" by the MP, Lieutenant Commander J. M. Kenworthy, and was forced to answer. ${ }^{75}$ He stated that the power to call out labor was governed by the Native Authority Amendment Ordinance. Ormsby-Gore also stated that by March 1500 Africans had been called out for labor with an anticipated call up of 700 Kamba. The Under Secretary stated that the wages were fixed at 14 shillings per month. This was two shillings less than the market rate for farm labor. ${ }^{76}$ As stated in the Native Authority Amendment Ordinance, Ormsby-Gore listed the penalty for non compliance as a fine of 150 shillings or two months imprisonment. Ormsby Gore emphasized that the power to call out labor

\footnotetext{
${ }^{73}$ Ibid., 13.

${ }^{74}$ Ibid., 954.

${ }^{75}$ Ibid., 955.

${ }^{76}$ Ibid., 956.
} 
was governed by Churchill's depatch.

Ormsby Gore reiterated that most of the answers to the questions would be furnished in an official report the $\mathrm{CO}$ was compiling on the subject. ${ }^{77}$ Ormsby Gore did state, however, that the 1912 Naive Authority Ordinance, the amending ordinances in 1920 and 1922, plus Churchill's despatch legislated the power to call out labor for government purposes. Consequently, labor could only be called out for a maximum of 60 days. He added that, for the most part, only able bodied men who had not been engaged in wage labor nor undertaken private production for cash crops were chosen. Ormsby Gore listed the number of coerced African labor at 1561 by March 1925 and restated the rate of pay for compulsory labor. In terms of penalties, the Under Secretary stated that the fine for non compliance was 150 shillings or 2 months confinement. ${ }^{78}$

Despite Ormsby-Gore's attempts at placation, the question of forced labor would not go away. On 20 May a debate on general questions of land and labor policy in Kenya, connected with the recent East African Commission, took place in the House of Lords. ${ }^{79}$ During the debate, the question of forced labor on the Uasin Gishu project came up again. Lord Olivier brought up the topic. Commenting on one of the main themes of the report, trusteeship, Lord

${ }^{77}$ Ibid., This report was the White Paper on compulsory labor associated with the Uasin Gishu railway extension. It would later be published as a command paper in July 1925, Kenya, Compulsory Labour for Government Purposes. It came about as a result of a query from Lord Olivier on 20 May in the House of Lords.

${ }^{78}$ Extract from Hansards Parliamentary Debates, 25 May 1925, CO 533/341.

${ }^{79}$ Also known as the Ormsby Gore Commission, after William Ormsby Gore. It was commissioned to look into the prospects of East African federation and to examine some of the more general problems of colonial rule in East Africa associated with the Dual Policy or promotion of both African production and European production. The report found that little had been done to promote African production and it also found that Africans feared loosing their land. Regarding its stated goal, the commission found little support for the idea of federation, outside the European minority. 
Olivier $^{80}$ asked how the building of railways contributed to African development. ${ }^{81}$

Consequently, he asked the $\mathrm{CO}$ to present all of the papers associated with the coercion of labor on the Uasin Gishu railway extension. ${ }^{82}$ The CO replied to Lord Olivier that papers associated with the forced labor issue and the Uasin Gishgu railway would be ready very soon ${ }^{83}$ The CO was still awaiting comment from Denham.

By June, conflicting reports about the forced labor situation with the railway construction began to surface at the $\mathrm{CO}$. As mentioned previously, in October one of the sub contractors on the railway construction, Griffiths and Coy had written to the $\mathrm{CO}$ complaining of a shortage of African labor that would preclude them from completing their section of the Uasin Gishu extension in time. However, Denham wrote to the $\mathrm{CO}$ in June stating that the actual reason the company was not able to complete the railway ontime was due more to its own incompetence as opposed to the shortage of African labor. ${ }^{84}$ As a result, Denham enforced penalty clauses against the company for going over the completion deadline for the railway extension.

\section{The Normalization of Communal Forced Labor}

In July, Amery's February despatch and other papers were published as a Parliamentary Command paper 2464. The new despatch built upon Churchill's previous despatch, Cmd 1509,

${ }^{80}$ Sydney Olivier (1859-1943) was a member of the Fabian Society and also had served in the CO from 1882 to 1924. He held several posts, most notably Governor of Jamaica from 19071913. He also published a book White Capital and Coloured Labour in 1906 that was very critical of colonialism in Kenya.

${ }^{81}$ Extract Hansards Parliamentary Debates, 20 May 1925, CO 533/338.

${ }^{82}$ Ibid.

${ }^{83}$ Ormsby Gore to Lord Olivier, 29 May 1925. CO 533/338.

${ }^{84}$ E. B. Denham to L. S. Amery, 18 June 1925, CO 533/332. 
further curtailing government forced labor, as previously mentioned. Officially, this marked the closing of the debate over forced labor. In this case the state had responded. Within Kenya, administrative officials were given instructions not to take actions that even flirted with compulsion for private purposes. The CO, working within the dictates of Churchill's despatch, chaperoned the forced labor issue immediately squelching a hint of controversy. The forced labor circular was explicit in stipulating the parameters of legal force. As a DC at Kisii stated, private labor recruiters who attempted to divert forced laborers away from the railway into private contractual relationships were liable for punishment and could be charged with the opprobrium of "using forced labour." 85

After 1925, government forced labor under section 8 (o), paid forced labor for state projects, would not be used again during peace time with the exception of December 1928 when the governor of Kenya requested approval to call out 1000 Meru for the destruction of Locusts. ${ }^{86}$ This movement away from forced labor did not apply to communal labor and porterage, however. The state would use communal labor all the way until independence for Kenya in 1963. The impact or effect of the labor controversies in 1920 and 1925 and the surrounding discourse resulted in the normalization of the use of communal labor while excising forced labor for private purposes and forced labor for government purposes.

Communal labor served as primitive accumulation for the state in colonial Kenya in the most vulgar way. It was forced labor without pay and allowed the state to extract the maximum surplus value of African labor while making Kenya colony more economically self sufficient.

\footnotetext{
${ }^{85}$ W. Slade Hawkins to All Labour Recruiters, 9 March 1925, Daily Correspondence Nyanza Province, 1908-1930, Deposit 1 Box 12, KNA, Syracuse University, Syracuse.

${ }^{86}$ A. C. C. Parkinson to J. Merrick, 14 January 1929, CO 533/386. 
Low wages ensured European profitability while no wages ensured government fiscal stability. An excerpt from a 1930 despatch from the S of S Lord Passfield is illustrative of the financial importance of forced labor. Passfield stated that, "I am aware that the chief obstacle in the way of abolishing unpaid labour under section 8 (h) is finance: and were it not for this practical difficulty I should have wished to press for its immediate abolition." ${ }^{187}$ Ironically, communal labor was more akin to slavery than the government recruitment of labor for private purposes that caused such an outcry from the humanitarian lobby, but it never received the same attention. The justification was that communal labor was merely an extension of tribal duties. Communal forced labor, constructed as an aspect of customary law, was not seen as exploitation for Europeans in the same sense as forced labor for private citizens. If one of the goals of trusteeship was to imbibe in Africans "habits of industry," then communal labor simply fulfilled that function, plus it was cheap labor.

Humanitarian groups were quick to condemn forced labor for private purposes in 1920, but the criticism of communal labor was uneven. As mentioned in Chapter Six, the Bishop of Zanzibar, one of the most ardent critics of forced labor for private purposes during the Northey labor circular fiasco, agreed with the premise behind communal forced labor. Although Oldham found communal labor objectionable, he was not prepared to mount a campaign for its removal as he had done with forced labor for private purposes. The ASAPS, for its part, criticized forced labor for private purposes as slavery and yet could not draw the same parallel with unpaid forced labor. For example, on 18 Februaury 1927 the ASAPS held a conference to address the aims of

${ }^{87}$ Secretary of State Lord Passfield to Governor of Kenya, 16 May 1931, CO 533/408. Page -259- 
trusteeship embodied in the Devonshire Declaration and colonial rule. ${ }^{88}$ At the conference Dr. Norman Leys criticized unpaid forced labor. Archdeacon Owen, also, discussed how communal labor is often camouflaged under different projects for purposes beyond communal necessity. However, one of the resolutions of the conference called for the "prohibition of all forms of compulsory labor excepting only those required for local communal purposes." ${ }^{89}$ The reasoning was that communal labor was part of the traditional duties that Africans would perform anyway. And, as such, it represented a much more authentic form of exploitation of African resources. In addition, for the purposes of trusteeship, communal labor was useful as didactic tool for inculcating strong work habits among the colonial denizens of Kenya.

ASAPS support of community, Africans living within tribal units with full access to land, lay behind the Society's reticence on the communal labor issue. This as evidenced in Chapter 2, lay at the heart of the organizations interest in aboriginal rights, trusteeship and free labor. The organizations contradictory stance on communal labor, in defense of community, had led it to similarly contradictory positions in other areas. For instance, in 1913 the ASAPS supported the passage of South African Natives land Act. This law implemented the principle of territorial segregation of the so called "races" in South Africa. It denied Africans the right to live outside of their "native" reserves while limiting them to only $7.3 \%$ of the total land. ${ }^{90}$ The ASAPS supported the act, despite the prior knowledge that most Africans were vehemently against it,

\footnotetext{
${ }^{88}$ ASAPS Conference, 18 February 1927, Box G/144, BFASS/APS, Rhodes House Library, Oxford.

${ }^{89}$ Ibid.

${ }^{90}$ Willan, Brian, “The Anti-Slavery and Aborigines Protection Society and The South African Natives Land Act of 1913, Journal of African History 20 (1) (1979), 84.
}

Page -260- 
because it saw in the act a way to protect African access to land. ${ }^{91}$

Despite this "traditional" and "communal" respect for communal labor, unpaid labor was such an odious proposition for most Africans that European wage employment or other alternatives offered more attractive options. As one missionary put it, "as to how Africans regard it, I can assure that in our discussions in the Church councils and elsewhere, there is no subject on which they speak with more heat and passion than in resentment against the operation of forced labor. ${ }^{, 92}$ For example, in 1920 the DC at Fort Hall district, Colonel Anderson, purposefully called out some young men from a missionary school for work, because they had not previously worked for a European in the past three months. He ordered them to work in an area that was known to be infested with malarial mosquitos. ${ }^{93}$ Most of the young men became sick. Anderson justified his action by stating that most of the "mission boys" were essentially shirking their "traditional" duties under the guise of religion anyway.

The state would pass amendments and ordinances to make better this institutionalization of force but stop short of abolishing it. For example, in 1928 the administration amended the Native Authority Ordinance again. The new amendment specifically stipulated that only able bodied men could be called out for the paid government forced labor. In addition, the amending ordinance added imprisonment of up to two months in addition to the fine of 150 shillings for failure to comply. According to Governor, Sir Edward Grigg, imprisonment was added as a

${ }^{91}$ Ibid., 85.

${ }^{92}$ Archdeacon Owen to Norman Leys, 11 February 1930, Church Missionary Society Archives, Owen Unofficial Papers, File: "Forced Labor 1920-27," University of Birmingham, Birmingham.

${ }^{93}$ Fred Mckerrick to Owen, 8 November 1920, Church Missionary Society Archives, Owen Unofficial Papers, File: "Forced Labor 1920-27," University of Birmingham, Birmingham. 
punitive measure to stop the practice of men sending their children or their wives as substitutes

on labor projects. ${ }^{94}$ However, as Archdeacon Owen's decade long campaign against forced labor evidenced, communal forced labor was intrinsic within Kenya and rife with abuses which ultimately stemmed from the fundamental contradiction of communal forced labor within the political economy of Kenya. In terms of the 1928 Native Authority Amendment Ordinance, Owen criticized the added penalty as too harsh due to the exorbitant amount of the fine. ${ }^{95}$ But, this was just one small aspect. As we shall see, Owen's campaign against forced labor brought to light a myriad of abuses and contradiction associated with this extension of "tribal" duties.

\section{Archdeacon Owen and Communal Labor: A Case Study}

The missionary, Archdeacon Walter Owen, in contrast to the ASAPS, consistently criticized communal labor in Kenya . Owen objected to forced labor because it skewed the civilizing mission, inherent in trusteeship, by utilizing African labor for purely economic accumulation on the part of the state or European settlers. This then pushed missionaries into a role of defending African interests against exploitation which diluted their ability to effectively perform their main duty, African salvation and edification. Missionaries in Kenya often defined themselves as the "African" voice of protest within Kenya colony. In some ways, as mentioned previously, their "voice" was more of an ambivalent and contradictory extension of the ideological travails of trusteeship in Kenya. Archdeacon Owen conducted a decades long campaign against communal labor abuses beginning in 1920 up to his death in 1945. R. van Zwanenberg stated of Owen that he "looked at the ideas behind the 'civilizing mission' to see whether they were being put into

\footnotetext{
${ }^{94}$ Grigg to Amery, 26 March 1928, CO 533/378.

95“Forced Labor in Kenya Colony,” Manchester Guardian, 6 December 1928.
} 
practice." 96

Despite this unctuous praise, Owen was contradictory in his support of African rights. Although he criticized forced labor he never questioned the legitimacy of colonial rule or the virtuosity of the civilizing mission in Kenya. As a result, he would frequently couple his criticisms of forced labor with reactionary statements that in most cases explicitly condoned African oppression. John Oldham described him, in reference to Owen's signature on the "Defense of Kenya," as: "not much of a thinker and consequently lands himself in a good many inconsistencies." $97 \mathrm{He}$, nonetheless, detailed his cases meticulously, in most instanceses down to the names of his informants and or Africans involved in the particular case. In addition to uncovering problems with communal labor itself, Owen's campaign was insightful also as a lesson in adjudication of African abuses. Addressing forced labor abuses internally through the colonial administration was wrought with inconsistencies which again were another reflection of the contradictions of colonial rule in Kenya.

A good example of Owen's problematic Afrocentrism surfaced in a couple of beating incidents connected with forced cotton growing. On 25 September 1923 Owen informed the DC at Kisumu that several agricultural instructors were using corporal punishment to enforce cotton growing. At a meeting of the Convention of Associations, Owen made the allegations publicly and followed that up with a letter to the Bishop of Mombasa. The DC then informed Owen that he should have informed the staff before going public with his allegations.

Consequently, on 9 July Owen wrote to the Senior Commissioner at Kisumu defending his

\footnotetext{
${ }^{96}$ R. van Zwanenberg, Colonial Capitalism, 148.

${ }^{97}$ Oldham to Steel-Maitland, 15 July 1921, IMC/CBMS, SOAS, London.
} 
actions at the Convention of Associations meeting. ${ }^{98}$ Owen made it clear that he was trying to defend the use of corporal punishment. ${ }^{99}$ For, in an earlier letter to the secretary of the Convention of Associations, Owen informed him that punishment for deserters from cotton growing was acceptable but not jail time. ${ }^{100}$ In a separate letter to John Oldham concerning the cotton growing incident, Owen stated clearly that "rightly or wrongly I have defended the principle of beneficient compulsion when applied to primitive people in their own interests." ${ }^{101}$ He added that the association he headed, the Kavirondo Tax Payers Welfare Association, could be depended upon to cooperate to the utmost with the administration in this regard. Owen followed this up with a letter to the DC at Kisumu urging the acceptance of beneficent compulsion or none at all. ${ }^{102}$

The main problem with reporting abuses under the forced labor regime was that Africans were not sufficiently protected against retribution from administrative officers, colonial chiefs and headmen. This hindered their ability to deliver testimony against abusive parties. Initially, when Owen began to campaign against forced labor abuses, he reported abuses to the local DC or PC but was told that he needed to also list the specific names of the Africans involved.

${ }^{98}$ Owen to Senior Commissioner, Kisumu, 9 July 1924, CMS Archives, Owen Unofficial Papers, File: "Forced Labor, 1920-27," University of Birmingham, Birmingham.

${ }^{99}$ Ibid.

${ }^{100}$ Owen to Secretary of Convention of Associations, 5 July 1924, CMS Archives, Owen Unofficial Papers, File: “Forced Labor, 1920-27," University of Birmingham, Birmingham.

${ }^{101}$ Owen to Oldham, 15 July 1925, CMS Archives, Owen Unofficial Papers, File: "Forced Labor, 1920-27," University of Birmingham, Birmingham.

${ }^{102}$ Owen to DC at Kisumu, 18 July 1924, CMS Archives, Owen Unofficial Papers, University of Birmingham, Birmingham. 
This was problematic for Africans were loath to give testimony concerning labor abuses. ${ }^{103}$ If a hearing was held, invariably the African laborers had to testify in front of both the DC and the headman or chief. Through Owen's efforts, however, several allegations of forced labor actually ended up before the $\mathrm{CO}$ in London. The process of adjudication had predictable results though.

For example, on 2 August 1924 allegations concerning coercion and cotton growing came up again. Owen wrote to the Senior District Commissioner for Kisumu stating that on 26 May 1924 he witnessed several Africans with kibokos or canes for beating taking about 50 laborers to dig a patch for cotton growing. The DC replied on 7 August that the "intention was to get at idlers who did not go in for increased production in the reserve of any kind, cotton, sim sim, maize or other product but spent their time loafing." 104 He added that the order was meant to make people who do not grow cotton fulfill their communal labor requirement. Owen took his complaints to the Senior Commissioner but was informed that no one showed up to the DC to complain about mistreatment, so he could do nothing. ${ }^{105}$

In another case, women were used on the construction of a major road in the Fort Hall district that involved overnight stays. The matter was investigated by the DC, Field Jones, but the women in question would not testify. ${ }^{106}$

${ }^{103}$ F. H. McKerrick to Owen, 2 December 1920, Church Missionary Society Archives, Owen Unofficial Papers, File: "Forced Labor 1920-27", University of Birmingham, Birmingham.

${ }^{104}$ C. Barton to Owen, 7 August 1924, CMS Archives, Owen Unofficial Papers, File: "Forced Labor, 1920-27," University of Birmingham, Birmingham.

${ }^{105}$ Senior Commissioner, Nyanza Province to Owen, 29 August 1924, CMS Archives, Owen Unofficial Papers, File: "Forced Labor, 1920-27," University of Birmingham, Birmingham.

${ }^{106}$ F. Mckerrick to Owen, 2 December 1920, CMS Archives, Owen Unofficial Papers, File: "Forced Labor, 1920-27," University of Birmingham, Birmingham. 
On 12 June 1929 Owen while traveling near Kisumu in Central Kavirondo came upon a group of African laborers working on a road, the Asembo road. Owen noticed that some of the workers, seventeen to be precise, were children. He questioned the children and wrote down their names. With this information Owen wrote to the DC of Central Kavirondo to complain about the children working on the road in violation of the Native Authority Ordinance which only called for able bodied men. ${ }^{107}$

The DC, A. Champion, followed up on Owen's accusation and interrogated the children. He questioned them in the presence of the headman, who called them out to labor, and got this response. Four of the boys stated that they were simply hanging around the road when Owen arrived, and he mistook them for workers. ${ }^{108}$ The remaining boys stated that they were merely throwing away grass from the road and not actually working on it. They added that they had come at the behest of their parents or on their own volition to help out in the interests of the community. As one boy stated or mouthed patriotically, "it is our duty, it is our country, we want a good road and if Bwana Owen wishes to go about in his car ("tembea na motoka yake") he may use it also."109 Another boy was found to be a registered adult. From this evidence the DC concluded that force was not applied and that the law did not apply to children who came to labor on their own accord. He then insinuated that Owen had a political agenda in exposing abuses and was a member of the Anti Slavery Society. ${ }^{110}$ Although not a member of the ASAPS, Owen was

${ }^{107}$ Owen to A. Champion, 12 June 1929, CMS Archives, Owen Unofficial Papers, File: "Forced Labor 1920-27", University of Birmingham, Birmingham.

${ }^{108}$ A. Champion to Owen, 18 June 1929, CMS Archives, Owen Unofficial Papers, File: "Forced Labor 1920-27," University of Birmingham, Birminham.

${ }^{109}$ Ibid.

${ }^{110}$ Ibid. 
in contact with the organization and fed them a number of cases which they publicized during the late 1920 s and 1930s. ${ }^{111}$

There were several cases of this nature. The pattern was repetitive. Cases were usually brought before the DC, who was also the magistrate in the case. The cases were not adjudicated by an impartial third party which ensured that the plaintiffs would be influenced to direct culpability away from the administrative personnel.

For example, on 6 November 1920 William Murtland, an administrative official at Kisumu, investigated an alleged case of forced labor by a headman Okaka wa Nego. ${ }^{112}$ Owen initially had brought up the allegations, after being informed by another chief familiar with the affair, that 15 Africans had been forced to work at a neighboring farm. At the inquest, Murtland questioned the headman Oaka but found that the 15 Africans in question all went to the farm of their own free will after a baraza held by the headman. ${ }^{113}$ Okaka told Murtland that Chief Ngonja accused him of forced labor on account of an old feud between the two. Murtland informed Owen that he was more inclined to believe the headman since his testimony corroborated the DC's own viewpoint. ${ }^{114}$ Murtland invited Owen to come to the inquisition of chief Ngonja to shed "some light on the native mind and its devious wanderings." ${ }^{115}$ After the meeting, however, Owen was

${ }^{111}$ Harris to Owen, 9 July 1929, CMS Archives, Owen Unofficial Papers, File: "Forced Labor, 1920-27," University of Birmingham, Birmingham.

${ }^{112}$ William Murtland to Owen, 6 November 1920, CMS Archives, Owen Unofficial Papers, File: "Forced Labor, 1920-27," University of Birmingham, Birmingham.

\footnotetext{
${ }^{113}$ Ibid.

${ }^{114}$ Ibid.

${ }^{115}$ Ibid.
} 
not convinced. ${ }^{116}$

Even if administrative personnel were found responsible for wrong doing, culpability could simply be deflected towards the lowest wrung on the administrative ladder, the colonial chiefs and headmen. When the DC was questioned about the incident he would simply reply that the fault was with the headmen who exceeded the boundaries of their instructions.

An incident in 1929 which was clearly state recruitment for private purposes illustrates this point. In this case Owen, initially, investigated a case of physical abuse of African laborers by a European overseer at Kisumu. Two Europeans had a contract with Homa lime works to cut wood for fuel in an area of Kisumu that was also infested with the tsetse fly. At the same time, the DC had ordered the removal of dense bush that was also a breeding ground for the fly. To kill two birds with one stone, the DC, G. H. Boulderson, allowed the European to use the African labor that had been called out initially under the Native Authority ordinance to clear the bush as a prescriptive measure against the tsetse fly. During the work, some of the Africans were beaten. The matter was investigated and eventually sent to the $\mathrm{CO}$ due to the agitation from Owen and the ASAPS in the press. The internal investigation by the DC revealed that it was the African overseer who actually did the beating and the injury to the Africans was slight any way. As a consequence the European was fined. This satisfied the S of S. ${ }^{117}$

Often, as one headman admitted, the DC did not have to state what was often implied. If the culpable headmen did not come up with the required labor, he would face the wrath of the DC.

${ }^{116}$ Notes made by Owen, 7 November 1920, CMS Archives, Owen Unofficial Papers, File: "Forced Labor, 1920-27," University of Birmingham, Birmingham,

${ }^{117}$ A.C. C. Parkinson to John Harris, 29 May 1929, Church Missionary Society Archives, Owen Unofficial Papers, File: “Forced Labor, 1920-27," University of Birmingham, Birmingham. 
In one case in April 1929, a DC found women working on a road in violation of both the Roads in Native Reserves ordinance and the Native Authority ordinance. The DC was infuriated and reprimanded the headman responsible. However, the maligned headmen would later admit to Archdeacon Owen, who was investigating the matter, that the order to acquire labor came so fast that he did not have time to find legal African male workers. ${ }^{118}$ So, he made do with the available female labor.

One former administrative official recounted that sometimes an order came abruptly from the DC to the chief or headman asking him to help a particular European settler obtain labor. ${ }^{119}$ If the chief had not obtained an adequate amount of labor in a week, the DC informed him that he would be reported to the CNC as "not helpful." This would produce the desired result. For the chief would then go and find the most defenseless Africans in the area and make them work or collect some sheep or chickens as fines. ${ }^{120}$

The abruptness of the calls to labor caught many Africans off guard. There would be no previous communication before the headmen or chief came calling for labor in the village. Archdeacon Owen found several cases of this type. In one case, women and young girls and boys were working on roads because the adult male laborers were either sick, away or simply would not come. ${ }^{121}$ One young women was laboring on a road with her infant son while her elderly father watched the child on the side of the road. Due to the abruptness of the call for labor, she

118“Kenya: an Episode in Forced Labor,” Manchester Guardian, April 1929.

${ }^{119}$ East African Standard, 8 November, 1919.

${ }^{120}$ Ibid.

${ }^{121}$ Owen to District Commissioner North Kavirondo, 6 May 1929, File: "Forced Labor, 1920-27," Owen Unofficial Papers, CMS Archives, University of Birmingham, Birmingham. 
was forced to drop everything and go to work with her infant son. ${ }^{122}$ This, despite the fact that the Native Authority Ordinance called only for able bodied men.

This semiconscious pressure emanating from the DC to the chiefs or headmen was also evident in another form letter for labor recruitment. In this instance, the DC in North Kavirondo needed labor for the construction of a large bridge, the Malakisi Bridge. The letter was addressed openly to the chief of South Kitosh and instructed him to organize labor for work on the bridge under the supervision of the Public Works Department. ${ }^{123}$ The letter made it clear that the chief was to supply no less than 100 men for every single working day on the bridge. The men were to work five days maximum with another batch of men replacing them for five more days and so forth.

This letter not only placed pressure on the chiefs to come up with the requisite number of men, it also, as Archdeacon Owen pointed out in a letter to the editor, it did not specify under which labor ordinance it was requesting labor. This was important because the Malakisi bridge was a large bridge used for heavy transport. It would not have fallen under the definition of "traditional" duties. In addition, the maximum number of days that laborers could work would have varied according to the labor ordinance. In this case, the labor was called out under the 1912 Native Authority ordinance.

Another of Owen's findings was that young boys and girls were frequently found in great numbers on many communal labor projects even though the specific ordinance called for able bodied men. In 1929 the issue of child labor in Kavirondo made news in London. The ASAPS questioned the Under Secretary of State for the Colonies concerning child labor in Kenya on

\footnotetext{
${ }^{122}$ Ibid.

${ }^{123}$ Owen to editor of East African Standard, 7 February 1930.
} 
17July. ${ }^{124}$ An MP, Graham Poole, asked whether the Under Secretary had received any reports of children working on roads in Kavirondo. He responded that the ordinances were limited to able bodied men and that employment of children was an offense against the law. The colonial state's investigation of the affair reiterated familiar themes. Most of the Africans Owen witnessed working stated that they were either loitering about the road and not actually working, or they were going in place of male relatives who were not available. ${ }^{125}$

On 21 December 1929 the CO responded to Owen's accusations. ${ }^{126}$ After investigation, the colonial state claimed that most of the children Owen found working were either there on their own volition or simply standing by. For instance, one boy, Ongao s/o Matete, stated he was just throwing earth and went there on his own. Another stated that his father was away so he went in his place. ${ }^{127}$ The headman stated that he called a baraza for the men to turn out for labor but there children showed up instead. He did not know why. Many of the fathers stated that when they were away their sons turned up in their place as was customary duty for each village. ${ }^{128}$ As a result, the $\mathrm{S}$ of $\mathrm{S}$ concluded that there was no objection to women and children arriving to work on their own volition but there must be safeguards. He admitted that if children arrive to work in place of adults who were legally called out, they should be sent back. But he added that "communal obligations are a commonly accepted factor in the daily life of a native village

${ }^{124}$ Harris to Owen, 19 July 1929, CMS Archives, Owen Unofficial Papers, File: "Force Labor, 1920-27," University of Birmingham, Birmingham.

${ }^{125}$ Grigg to Passfield, 28 September 1929, CO 533/386.

${ }^{126} \mathrm{~K}$. Baxter to Owen, 21 December 1929, CMS Archives, Owen Unofficial Papers, File: "Forced Labor, 1920-27," University of Birmingham, Birmingham.

${ }^{127}$ Ibid.

${ }^{128}$ Ibid. 
community, and it is difficult for the natives concerned to understand that any particular member of that community is exempt from performing such a part of common obligations." ${ }^{129}$ In addition to this outlandish remark, he added that children from the earliest days in African communities had to perform duties so it would be difficult to stop them when there are communal responsibilities like building bridges. ${ }^{130}$

Although these problems of abuse with communal forced labor were vexing to Archdeacon Owen, what he found fundamentally wrong was that the ordinances governing forced labor were not published in a language that Africans could understand generally. Missionaries in Kenya frequently called for the ordinances governing forced labor to be posted in an African language like Kiswahili. The understanding being that If the ordinances were published In Kiswahili, the "burden of Native protection" would shift from the shoulders of missionaries. As Archdeacon Owen stated:

With regard to the whole question of compulsory labor it is my strong conviction that the only satisfactory way of dealing with the criticisms . . is for the government to translate into Kiswahili and to circulate broadcasts among the natives, ordinances and circulars which deal with the supply of labour. The onus of protest would then be cast upon the native concerned, and in the lack of such protest government would have a very strong position, and us missionaries would be relieved of a self imposed duty the performance of which makes inroads upon

\footnotetext{
${ }^{129}$ Ibid.

${ }^{130}$ Ibid.
} 
time which could be devoted to education and evangelism. ${ }^{131}$

Despite his concern for African welfare, Archdeacon Owen's comments reflect more of an interest in preserving trusteeship or essentially control than actual concern for African mistreatment. His comments indicate that humanitarian criticisms of bonded labor in Kenya were more about refining colonial rule under the paternal gaze trusteeship.

Archdeacon Owen's statement brings up another point as well. Since the ordinances that governed forced labor were published in English, most Africans could not read them. The end result was Africans did not know specifically, sometimes, under what ordinance their labor was being procured or for that matter the "communal" purpose of their labor. For example, three African males from South Kavirondo once wrote to Owen complaining that they had been arrested and fined for refusing to do road work for the Public Works Department. ${ }^{132}$ They refused to work because they had jobs and had been previously informed that salaried work qualified as an exemption from the corveé. After their arrest they wrote to Owen in exasperation asking him for details concerning whether the rule of the ordinances had changed.

For his part, Owen wrote to the DC of South Kavirondo and stated,'I would be grateful if you could give me any information which would help me to convince them that they have been justly condemned." 133 The DC replied to Owen that one of the Africans, Gideon Oketch, was fined 100

131،Report of the Sub Committee of Representative Council of Alliance," CMS Archives, Owen Unofficial Papers, File: “Forced Labor,1920-27," University of Birmingham, Birmingham

${ }^{132}$ Gideon Oketch to Owen, 13 August 1927, CMS Archives, Owen Unofficial Papers, File: Forced Labour 1920-27, University of Birmingham, Birmingham.

${ }^{133}$ Owen to DC South Kavirondo, 25 August 1927, CMS Archives. Owen Unofficial Papers, File: "Forced Labor, 1920-27," University of Birmingham, Birmingham. 
shillings because he refused to turn out for communal labor under section $8(\mathrm{~h}){ }^{134}$ In another similar circumstance, Owen handled, the case of a Luo who had converted to Islam and lived in a township and subsequently sought exemption from communal labor requirements. The Senior Commissioner of Nyanza Province saw otherwise, however, as he stated in reply to Owen, "there was no reason that I could see why a heathen native who had changed his religion even if he resided in a township or trading center should not come within the scope of the Native Authority Ordinance." $" 135$

With ordinances written in English, headmen and chiefs frequently were unaware of strict letter of the law. This gave them the latitude to interpret the labor ordinances in any way they saw fit. But, more importantly it gave the local District Commissioner a compliant scape goat if abuses occurred. In one complaint concerning children working on roads, the local DC at Kisumu simply stated that his instructions to the headmen were misinterpreted by the headmen and that, essentially, the problem was children followed their parents to labor on the road on their own free will. ${ }^{136}$

In addition to the language problem, another difficulty with the forced labor ordinances was the length of servitude for the prospective African laborer. The Native Authority Ordinance called for able bodied men to work for six days a quarter. This equated to two days per month. This presented problems if the labor project was of long duration, for it made it difficult,

${ }^{134}$ E. H. Anderson to Owen, 27 August 1927, CMS Archives, Owen Unofficial Papers, File: "Forced Labor, 1920-27," University of Birmingham, Birmingham.

${ }^{135}$ Senior Commissioner Nyanza to Owen, 30 August 1927, CMS Archives, Owen Unofficial Papers, File: “Forced Labor, 1920-27," University of Birmingham, Birmingham.

${ }^{136}$ Arthur Champion to Owen, 18 June 1929, Church Missionary Society Archives, Owen Unofficial Papers, File: "Forced Labor 1920-27, University of Birmingham, England. 
logistically, to have laborers coming and going every two days. Consequently, many laborers worked beyond the two days per month, usually up to six days, while some worked up to and beyond the twenty four days a year in one stretch. One individual in Central Kavirondo complained to Owen that his brother and others were detained for a month, as opposed to six days, clearing bush for fuel for a European who also beat them. ${ }^{137}$ They were called out under the Native Authority Ordinance. Owen wrote to the DC of Central Kavirondo inquiring about the accusations and wondering if unpaid work was being done for the European fuel cutter. There was no way to prove that they had actually completed their labor requirement. The DC replied to Owen that there was no way they could get any reasonable work accomplished unless the men were required to work their full 24 days in one stretch. ${ }^{138}$ He stated corporal punishment was strictly unauthorized but essentially admitted there was state recruitment for private purposes. Tamberson explained that a European held a fuel concession in an area that was also infested with sleeping sickness. The entomologist suggested removal of bushes and shrubs in he area. Since the preventative prescription against sleeping sickness correlated with the needs of the fuel cuter, Tamberson stated that the local headman was instructed to call out "free labor" for the European. ${ }^{139}$

The "communal" aspect of the labor requirements under the Native Authority ordinance was often debatable. The amorphous traditional duties, known as kazi ya umoja in Kiswahili or among the Luo as Methia or Saga Luo were more casual in their requirements and were not

\footnotetext{
${ }^{137}$ Bo Samba to Owen, 6 November 1927, Church Missionary Society Archives, Owen Unofficial Papers, File: “Forced Labor 1920-27," University of Birmingham, England.

${ }^{138}$ Tamberson to Owen, 7 November 1927, Church Missionary Society Archives, Owen Unofficial Papers, File: “Forced Labor 1920-27,” University of Birmingham, England.

${ }^{139}$ Ibid.
} 
binding. A person might brew beer and ask his neighbors to aid in building a hut or kraal.

However, the element of compulsion was not there. Theoretically, the communal labor for state purposes was supposed to be a continuation of traditional tribal duties that an African might owe to his chief, but in Kenya there were few before colonial rule.

In actuality, communal labor frequently went beyond the requirements of communal necessity. In many cases the state used African labor to build heavy bridges like the Malakisi bridge, or major roads or even simply to work on the local headman's shamba. In response to another one of Owen's allegations, acting governor Monson admitted in 1929 that the Public Works Department used labor under section 8 (h) of the Native Authority Ordinance to build and maintain the many local roads. ${ }^{140}$ He defended this use of native authority by stating that most of the roads were earthen and required constant upkeep. Moreover, when the roads ran through a local community, it was standard procedure to assign a patch of the road for upkeep to the local community.

Although never able to mount a comprehensive campaign against forced labor abuses like Oldham, Owen's voice of protest sometimes earned him disapproval. His habit of going to the press with allegations caused agitation within some quarters. A minute from a $\mathrm{CO}$ official, Parkinson, stated that "Archdeacon Owen is afraid of all forced labor ... ignores all positive things government does." ${ }^{141}$ On 1 February 1930 the Bishop of Mombasa, R. S. Heywood, wrote to Governor Grigg that "we as a whole do not back up his policy of writing so often for

\footnotetext{
${ }^{140}$ Monson to Passfield, 9 July 1929, CO 533/386.

${ }^{141}$ Minute by A. C. C. Parkinson, 13 December 1930, CO 533/404.
} 
papers." ${ }^{142}$ In March 1930 the Secretary of the CMS wrote to Owen gently chiding him about going to the press with allegations. ${ }^{143}$ This was followed by another letter from the CMS informing Owen that missionaries who received government money were barred from going to the press. ${ }^{144}$ On 30 September 1930 the secretary of the Executive Council of the CMS wrote to Owen's chiding him that to "deprecate any further conflict in the press please submit any letters to me as secretary before publication in standard writing." ${ }^{145}$ At this point Owen actually offered his resignation in October, but it was rescinded. ${ }^{146}$

Despite the opprobrium, Owen continued his campaign up until his death in 1945. For example, as late as 1938 he was still bringing up cases of abuse before the CO. In 1938 Owen met with the S fo S, Malcolm Macdonald, to discuss many topics that ranged from forced marriages to child labor and penal sanctions. ${ }^{147}$ Concerning child labor, Owen's contended that the minimum age for children working in Kenya had been reduced. Consequently, very young children were found on labor projects. In addition, he complained that the European employers needed to be responsible for repatriating children after their contracts were fulfilled. During the meeting, Macdonald listened to Owen's many points, but concerning child labor he informed

${ }^{142}$ Heywood to Grigg, 1 February 1930, CMS Archives, Owen Unofficial papers, File: "Forced Labor 1920-37," University of Birmingham, Birmingham.

${ }^{143}$ W. Cash to Owen, 11 March 1930, CMS Archives, Owen Unofficial Papers, File: "Forced Labor 1920-27," University of Birmingham, Birmingham.

${ }^{144}$ Hooper to Owen, 12 March 1930, CMS Archives, Owen Unofficial Papers, File: "Forced Labor, 1920-27," University of Birmingham, Birmingham.

${ }^{145}$ W. Pitt Pitts to Owen, 7 October 1930, CMS Archives, Owen Unofficial Papers, File: "Forced Labor, 1920-27," University of Birmingham, Birmingham.

${ }^{146}$ Owen to Pitt Pitts, 9 October 1930, CMS Archives, Owen Unofficial Papers, File: "Forced Labor 1920-27," University of Birmingham, Birmingham.

${ }^{147}$ Archdeacon Owen and Child Labour, CO 874/12. 
Owen that he would respond more fully to his concerns after receiving more information on child labor and penal sanctions. Following the meeting, Macdonald sent a despatch to the governor of Kenya, Sir Robert Brooke-Popham, on 28 October concerning the points Owen raised.

On 5 January 1939, the CO responded to Owen. ${ }^{148}$ The letter stated that they were still awaiting information from Kenya; however, the $\mathrm{S}$ of $\mathrm{S}$ wanted to clarify a few points that Owen made. Concerning child labor, the employment of juveniles was governed by section 4 of the Employment of Women, Young Persons and Children Ordinance of 1933. ${ }^{149}$ The ordinance also stipulated that the legal age of employment for juveniles was fourteen years of age. The $\mathrm{CO}$ also informed Owen that Macdonald had formed a committee to look into the matter of child labor.

Despite the humanitarian "victory" in 1921 culminating in Churchill's despatch and Amery's despatch in 1925 curtailing government forced labor, as evidenced from Archdeacon Owen's campaign against communal labor, forced labor was still very much in use. Forced labor for private purposes had been excised and government forced labor for state purposes had been eventually curtailed, but, as Owen's campaign showed, communal labor was still abused quite frequently by the state. Communal labor was firmly entrenched in the political economy of Kenya and would be difficult to eradicate without answering questions concerning economic viability. First in 1921, and, then in 1925, the response from the CO to forced labor in colonial Kenya was the culmination of a process of legitimation of state control of African labor. In 1925 the state was quick to respond to the situation and snuff out any potential forced labor crises. In so doing, the state reinforced its legitimacy as an institution responsive to the concerns of its colonial wards. The importance of the Uasin Gishu forced labor controversy was that there was

\footnotetext{
${ }^{148}$ Gerald Creasy to Owen, 5 January 1939, CO 874/12.

${ }^{149}$ Ibid.
} 
none.

The 1925 issue of forced labor on the Uasin Gishu railway extension never received the same attention from humanitarians. By this point, Oldham had moved to questions of African education and the so called "Indian Question." The ASAPS did not tackle the issue, through a parliamentary debate, as with the forced labor crises of 1920. The reason for this was that the government had responded before any real controversy could develop.

Amery's despatch reaffirmed Churchill's earlier despatch that forced labor for private purposes was illegal, and it went further in curtailing government forced labor for so called state purposes by limiting the number of Africans that could be called out at one time. But Amery's despatch did not touch upon forced labor for so called communal purposes. Communal labor was justified as an extension of traditional duties. The response from the $\mathrm{CO}$ buttressed the institutional legitimacy of the relatively autonomous colonial state but also had the effect of normalizing communal labor. In 1921 and 1925 the CO responded and the problem of forced labor was surmounted institutionally. However, because, communal labor was seen as an extension of communal duties it was further strengthened since its existence did not challenge the institutional mandate of colonial rule. It was labor by and for Africans. The 1925 labor controversy, further excised more objectionable labor exercise which only left forced labor that was for the good of the community involved. However, as Archdeacon Owen's campaign reflected, this form of labor by and for Africans was rife with contradictions and abuse but was firmly entrenched within the colonial economy.

The economic problem, African labor, European settler production, was surmounted institutionally. However, under the rubric of community, communal labor never received the same challenge as government forced labor for private purposes. 


\section{Chapter 8}

\section{Conclusion: Furthering Communal Labor: Forced Labor as an Abstraction}

Communal forced labor remained instrumental to the colonial economy of Kenya up to independence in 1963. The passage of the International Labor Organization (ILO) forced labor convention of 1930 proscribed certain forms of forced labor. It called on the signatories to suppress the use of forced labor within the shortest possible period of time. Despite this, it would have little real effect on Kenya since it did not apply to forced labor relating to minor communal services. The convention also exempted forced labor for military service, civic obligations, prison labor and emergencies. However, since Great Britain was a signatory to the convention, it did force the administration in Kenya to submit periodic reports as to the working of the forced labor convention within the colony.

Despite the humanitarian "victory" in 1921 that brought an end to forced labor for private purposes and the apparent curtailment of forced labor for state projects after 1925 , communal labor remained. As we have mentioned earlier, the continuance of communal labor was a reflection of the contradictions of colonial rule in Kenya. However, the discourse surrounding the forced labor issue represented an abstraction of the problems of political economy in Kenya. In response to the discourse, the $\mathrm{CO}$ moved to excise forced labor for private purposes and curtail forced labor for state purposes. Forced labor for private purposes weakened the relative autonomy of the colonial state in Kenya as a, seemingly, neutral and impartial institution. As Bruce Berman has mentioned of the colonial state in Kenya, "the state defined and regulated social relations within juridico-political forms that treat them as the only way in which social 
activity may legitimately be conducted." "The state in Kenya, according to Berman, established legitimacy through its ability to create and both appear as an impartial institution that channeled or coopted the social relations of a society. ${ }^{2}$ Through institutions like the bureaucracy, the state strove to coopt all of the disparate elements of its constituency in Kenya and, thereby, increase its own power and domination. The ethos of the trust principle served as the ideology of control and moral legitimacy. The birth of the bureaucratic state in Kenya, baptized in the legitimating waters of institution, rested upon a systematic knowledge of African culture, values and mores. As PC Ainsworth gave testimony to during the 1912 Native Labour Commission, tribal cohesion or community was deemed the more salient aspects of what it meant to be African. The agitation over the Northey circulars and the response from the $\mathrm{CO}$ strengthened the institutional legitimacy of the colonial state in Kenya. The focus upon forced labor for private purposes mirrored the institutional acceptance of "community" in the form of communal forced labor.

Ultimately, the response from the $\mathrm{CO}$ and the discourse surrounding the forced labor issue masked the vital importance of forced labor to the colonial economy by curtailing forced labor for state purposes and excising forced labor for private purposes. Forced labor for private purposes with its close associations with slavery and manipulation of African labor purely for European benefit, weakened the moral legitimacy of the colonial state and hence its relative autonomy. However, unpaid African communal labor allowed the state to accumulate on a scale only paralleled by slavery, ironically. With the victory won in 1925 after Amery's despatch, the state could progress forward and use communal labor with impunity. Archdeacon W. Owen's campaign against communal labor was instructive, in this regard, for it showed the intractability

\footnotetext{
${ }^{1}$ Berman, Control and Crises in Colonial Kenya, 27.

${ }^{2}$ Ibid., 31-32.
} 
of communal forced labor.

The hubris of the humanitarian anti slavery ideology, with its supreme confidence in free labor, was evident in the campaigns against the bonded labor in all its forms on the East African coast since 1870 . Formed in the post emancipation milieu of 1833, organizations like the BFASS and the APS had been active in promoting "native" welfare as their mandate. The BFASS consistently attacked slavery as a moral evil, but also attacked it because it impugned the ideals of trusteeship inherent in the civilizing mission. In addition, as evidenced in Chapter Two, beyond the esoterica of morality, humanitarian attacks on slavery were also an articulation of free wage ideology. The vision of Africans working for wages or on their own plots was integral to humanitarian constructions of the benefits of colonial rule.

This vision of Africans laboring rested upon an inherent distaste of slavery in all its forms and followed the organizations initiatives in East Africa. In the 1870s the organization began to attack the East African Slave trade. With the assumption of British influence after 1895 the Society continued with its mandate against "slavery under the British flag" and turned to pressuring the government to end slavery in the EAP. This anti slavery ideology continued in the ASAPS criticism of other forms of slavery in the EAP such as forced labor for private purposes. This protest came up first in 1912, as a result of the Native Labour Commission, and flared up again in 1920.

Beyond slavery, at the root of the forced labor issue in Kenya in 1920 was the tension between settler production, peasant production and the relative autonomy of the colonial state. Forced labor for private purposes was a reflection of the poverty of European settlers and the subsequent need for a cheap, stable African labor supply. However, by directly implicating the state as an accumulator for settler interests, forced labor for private purposes weakened the 
relative autonomy of the colonial state and destabilized its institutional legitimacy. Communal forced labor did not. Communal labor with its roots in "tribe" and "community" was as tightly wrapped as the "man in the blanket" within the matrix of the civilizing mission and by extension the institutions of legitimation of state power, apropos indirect rule. As mentioned in Chapter Six, colonial administrators saw themselves as the experts on African community not the humanitarians. In a sense, this bridging of the gap between the two groups via Ainsworth and Norman Leys allowed the state to move on the forced labor issue in 1921.

There was no such divide when it came to the issue of communal labor, however. Communal labor, as a continuance of traditional duties was accepted, with a few exceptions, by humanitarians, the state and the CO. As a minute from W. Bottomley of the CO illustrates in regard to communal labor: "I agree Native society is founded on duties of one kind or another."3 And, yet, in 1931 the governor of Kenya, Sir Joseph Byrne, would candidly admit of communal labor that, "while, therefore, it may be argued with truth that this form of compulsory labor has no definite sanction in native custom it is equally true that it is not repugnant to native custom."4 Economic utility was more important. As an artifice of community, it merely strengthened the institutional legitimacy of the state. For, what was better than teaching Africans to work for the good of their community. As an instrument of primitive accumulation, communal labor was, by necessity, a reflection of the economic weakness of the colonial state. This crucial aspect accounted for its continuance, but the ideological justifications for communal labor, unlike forced labor for private purposes, were shrouded in the ethos of community. Used in this way, the African "community" was at once a bulwark against modernity but also, ironically, was a

${ }^{3}$ Minute by W. Bottomley, 30 November 1929, CO 533/386.

${ }^{4}$ Byrne to Passfield, 4 August 1931, CO 533/408. 
vessel for economic change that lay at the foundations of trusteeship. Communal forced labor continued to be an integral part of colonial rule. It was used for state projects on a scale that went far beyond light bridges and foot paths stipulated in the 1912 Native Authority Ordinance. It was essentially government unpaid forced labor for state purposes, more akin to slavery than the forced labor for private individuals, because, under the latter, Africans, at least, received a gratuity. Ironically, coercion within the context of community was not defined as forced labor in the same way as coercion in the interests of individuals or the state. Communal labor was a recognition of the ambiguities of defining free labor. Under the organic umbrella of community, communal labor was not forced labor but a continuation of otherness, tribe.

The discourse surrounding the "Northey Crises" was the reification of the political and economic dilemmas of colonial rule in Kenya. With Churchill's despatch in 1921, forced labor for private purposes was specifically disavowed and government paid forced labor for state projects was curtailed per request to the S of S. Amery's despatch in 1925 further limited government forced labor, with the exception of porterage, by placing a ceiling on the number of Africans who could be recruited at four thousand. It was effectively discontinued after this point anyway. The controversy surrounding the forced labor issue in Kenya was, in a sense, the "abstraction" of this contradiction of peasant labor and settler production. The discourse focused the issue more on the hollow ideals of anti-slavery and trusteeship. Consequently, it was easier for the state to excise certain aspects of "slavery" while retaining other forms of bonded labor. Slavery, as an institution, had been bounded and disavowed by the British since 1833 . Forced labor for private purposes harkened back to slavery. The humanitarian criticism of forced labor by Oldham, the ASAPS and other humanitarians and the response from the CO essentially disavowed this form of accumulation for European production because it was no longer accepted 
institutionally. As mentioned previously, forced labor for private purposes also weakened the power of the normative state in Kenya. However, the discourse surrounding forced labor had the effect of shifting focus away from a more central issue, African labor and state accumulation. After the "victory" had been won, humanitarian focus on forced labor in Kenya never was of the same magnitude. The abstraction of the essential conflict, African labor and European production, allowed the state to accumulate African labor in the name of community.

Holger Hansen's comments about the missionary Bishop Tucker's campaign to end forced labor in Uganda are a good illustration of the contradictions of humanitarian criticism of bonded labor and can be applied to Kenya as well. Of Bishop Tucker, Hansen stated that he "considered the principle of forced labor to be a violation of the principle of freedom and justice for "subject races" which was supposed to guide the whole colonial enterprise." "freedom" and "subject races" was never questioned. Humanitarian rhetoric designated certain types of discourse, like slavery, in opposition to trusteeship. Communal labor, on the other hand, was not constructed in opposition to slavery. It was not juxtaposed against trusteeship. Within the context of the time period in colonial Kenya, these concepts "slavery" and "community" were not mere words that reflected abstract ideas. They were the contextual apparatus of economic and political practices in Kenya. Essentially, they were reflective of the underlying structures that conditioned the political economy of Kenya. Michel Foucault has described power as diffused throughout society. His description of the penal system showed how power was diffused within the apparatuses and discourses of a society. As he stated, the locus of carceral power was "not the 'center of power,' not a network of forces, but a multiple network of

${ }^{5}$ Hansen, “Forced Labor in a Missionary Context," 190.

Page -285- 
diverse elements - walls, space, institution, rules, discourse." ${ }^{\prime 6}$ For Foucault then the power of the penal system was diffused throughout these carceral mechanisms like discourse which also served to normalize the articulation of power. In colonial Kenya the discourse of community reflected in the acceptance of communal labor was a manifestation of this diffused nature of power as the state sought justification of forced labor beyond the more obvious coercive apparatuses of state power . To use Gramsci in a much more narrow way, the discourse of community, embodied in trusteeship was the embodiment of a hegemonic structure of consent that ensured moral legitimacy for the colonial state, but only in the metropole. $\quad$ The "state" in this sense was not merely the colonial administration or the Colonial Office but the processional apparatuses of civil society. Returning to the concept of "relative autonomy" the state was a process. It was constituted but not essentially constitutive.

Ironically, forced labor for private purposes was construed negatively partly because it impinged on "tribal" cohesion by sending African men out of the reserves to work for Europeans. However, communal forced labor would be justified under the rubric of community. Essentially, African accumulation for state purposes was institutionally acceptable. This intensified the use of forced labor under communal justifications as evidenced in Archdeacon Owen's Quixotic campaign against the institution of forced labor. The discourse surrounding the forced labor issue abstracted the labor issue away from the unstable conflict between settler production and African labor to the more enduring plane of principle. African slavery was no longer an acceptable form of labor organization. Communal forced labor was in the interests of the

${ }^{6}$ Foucault, Discipline and Punish, 307.

${ }^{7}$ Quintin Hoare and Geoffrey Nowell Smith, eds., Selections from the Prison Notebooks of Antonio Gramsci (New York: International Publishers, 1971) 
community; work benefitted Africans, the state and European planters. Africans were taught a healthy work ethic, the state and European settlers profited from African labor. However, the question of colonial rule was never an issue. 


\section{BIBLIOGRAPHY}

\section{Primary Sources}

\section{Manuscripts and Private Papers}

Manuscripts: Great Britain, Public Record Office, Colonial Office Archives, London

CO 533 Series, Original Correspondence, Kenya

CO 323 Series, Colonies, General Original Correspondence

CAB 37/40-43, Records of the Cabinet Office

Manuscripts: Rhodes House Library, Oxford

Papers of the British and Foreign Anti-Slavery and Aborigines Protection Society, Mss Brit. Emp. S 22.

Papers of Elspeth Huxley Mss Afr. 57

Records of London Group on African Affairs Mss Afr. 427.

Papers of John Ainesworth Mss Afr. S. 382.

Manuscripts: SOAS, London.

International Missionary Council and Conference of British Missionary Societies Joint Archive: Africa.

Manuscripts: University of Birmingham, Birmingham.

Church Missionary Society Archive

Archdeacon Owen Unofficial Papers, Correspondence files, Official papers AC 83013 
Official Publications

COLONY AND PROTECTORATE OF KENYA

Report of the Labour Bureau Commission 1921. Nairobi: Government printer, 1921.

Native Labour Commission, 1912-13 Evidence and Report. Nairobi: Government Printer, 1913.

\section{GREAT BRITAIN}

Parliamentary Debates (Commons), $5^{\text {th }}$ series, (1917), 95 and 96; (1918) 106; (1920) 125 and 126 and 128 and 133; (1925) 184.

Parliamentary Debates (Lords) $5^{\text {th }}$ Series, (1920) 41.

Correspondence Respecting the Abolition of the Legal Status of Slavery in Zanzibar and Pemba. C.8858, London: HMSO, 1898.

Correspondence Respecting the Status of Slavery in East Africa and the Islands of Zanzibar and Pemba. C.9502, London: HMSO, 1899.

Correspondence Respecting Slavery and the Slave Trade in East Africa and the Islands of Zanzibar and Pemba. Cd. 593, London: HMSO, 1901.

Report on Slavery and Free Labour in the British East Africa Protectorate. Cd. 1631, London: HMSO, 1903.

Despatch to the Governor of the East Africa Protectorate relating to Native Labour and Papers Connected. Cmd. 873. London: HMSO, 1920.

Despatch to the Officer Administering the Government of Kenya Colony and Protectorate Relating to Native Labour. Cmd. 1509. London: HMSO, 1921.

Kenya Compulsory Labour for Government Purposes. Cmd. 2464. London: HMSO, 1925.

BRITISH AND FOREIGN ANTI SLAVERY SOCIETY

Peace, Joseph. How We Countenance Slavery in the East African British Protectorates. London: British and Foreign Anti Slavery Society, 1895.

A Summary of the Work of the British and Foreign Anti Slavery Society During the $\mathbf{1 9}^{\text {th }}$ Century. London: British and Foreign Anti Slavery Society, 1900. 


\section{Sixty Years Against Slavery: A Brief Record of the Work and Aims of the British and}

Foreign Anti Slavery Society, 1839-1899. London: British and Foreign Anti Slavery Society, 1900.

Anti Slavery Reporter, $5^{\text {th }}$ Ser. Vol 1-34 (1909-1945); $4^{\text {th }}$ Ser. Vol 1-29 (1881-1909); $3^{\text {rd }}$ Ser. Vol 1-22 (1853-1880)

\section{ABORIGINES PROTECTION SOCIETY}

Report of the Parliamentary Select Committee on Aboriginal Tribes. London: William Ball, Aldine chambers, Paternoster Row, and Hatchard and Son, Piccadilly, 1837.

The Aborigines Protection Society: Chapters in its History. London: P. S. king and Son, 1899.

Fox-Bourne, H. R. The Claims of Uncivilised Races. London: Aborigines Protection Society, 1900.

\section{ANTI SLAVERY AND ABORIGINES PROTECTION SOCIETY}

Harris, John. Back to Slavery?. London: Anti Slavery and Aborigines Protection Society, 1921.

Buxton, Charles Roden. The Exploitation of the Coloured Man. London: Anti Slavery and Aborigines Protection Society, 1925.

Greenidge, C.W.W. Forced Labour. London: Anti Slavery and Aborigines Protection Society, 1943.

\section{Secondary Sources}

\section{Unpublished Papers}

\section{DISSERTATIONS}

Banton, Mandy Kathleen. "Colonial Office Supervision of the Introduction and Revision of Labour Legislation in British Africa.” Ph.D. diss., University of London, 1993.

Grant, Kevin Patrick. “A Civilised Savegery’ British Humanitarian Politics and European Imperialism in Africa 1884-1920.” Ph.D. diss., University of California Berkeley. 1997.

Mayes, Charles R. "The Aborigines Protection Society and British Colonial Policy in the Nineteenth Century." Ph.D. diss., University of Maryland, 1948. 
Nworah, Kenneth Dike. "Humanitarian Pressure Groups and British Attitudes Towards West Africa 1895-1915.” Ph.D. diss., University of London, 1966.

Sinclair, Keith. The Aborigines Protection Society and New Zealand: A study in Nineteenth Century Opinion.” Ph.D. diss., University of Auckland, 1946.

Swaisland, H.C. "The Aborigines Protection Society in British Southern and West Africa." Ph.D. diss., Oxford University, 1967.

Temperley, Howard, “The British and Foreign Anti-Slavery Society, 1839-1868.” Ph.D. diss., Yale University, 1960.

Westing, Peter. "The Influence of the Antislavery and Aborigines Protection Society upon the Attitude of the British Government Towards the Native Franchise and Representation in South Africa 1908-1939." Ph.D. diss., Dalhousie University, 1983.

Whitehead, Rachel. "The Aborigines Protection Society and the Safeguarding of African Interests in Rhodesia, 1889-1930.” Ph.D. diss., Oxford University, 1975.

Zeleza, Paul Tiyamba. "Dependent Capitalism and the Making of the Kenyan Working class During the Colonial Period." Ph.D. diss., Dalhousie University, 1982.

Books

Ake, Claude. A Political Economy of Africa. Essex. Longman Group Limited, 1981.

Althusser, Louis and Etienne Balibar. Reading Capital. Translated by Ben Brewster. New York: Pantheon Books, 1970. , Translated by Ben Brewster. For Marx. New York: Verso, 1969.

Amin, Shahid and Van de Linde, Marcel. Peripheral Labor Studies in the History of Partial Proletarianization. Cambridge. The Press Syndicate of the University of Cambridge,

Arrighi, Giovanni, ed. Essays on the Political Economy of Africa. New York. Monthly Review Press. 1973.

Bender, Thomas., ed. The Anti-Slavery Debate. Berkeley: University of California Press, 1992

Beachey, R. W. The Slave Trade of Eastern Africa. New York. Harper and Row, 1976.

Berman, Bruce. Control and Crisis in Colonial Kenya. Athens: Ohio University Press, 1991.

Berman, Bruce and Lonsdale, John. Unhappy Valley: Conflict in Kenya. Athens: University Press, 1992. 
Braverman, H. Labor and Monopoly Capital: The Degradation of Work in the Twentieth Century. New York: Monthly Review Press, 1974.

Brett, E. A. Colonialism and Underdevelopment in East Africa: The Politics of Economic Change, 1919 to 1939. New York: NOK. 1973.

Bush, M. L. Servitude in Modern Times. Cambridge: Polity Press, 2000.

Cell, John w., ed. By Kenya Possessed: The Correspondence of Norman Leys and J. H. Oldham 1918-1926. Chicago: University of Chicago Press, 1976.

Clayton, Anthony and Donald Savage. Government and Labour in Kenya 1895-1963. London. Frank Cass, 1974.

Cline, Catherine. E. D. Morel, 1873-1824: The Strategies of Protest. Belfast: Blackstaff Press, 1980.

Cooper, Frederick. Decolonization and African Society. Cambridge: Cambridge University Press, 1996.

From Slaves to Squatters: Plantation Labor and Agriculture in Zanzibar and Coastal Kenya 1890-1925. New Haven: Yale University Press, 1980.

Cooper, Frederick and Stoler, Anne. Tensions of Empire: Colonial Culture in a Bourgeoisie World. Berkeley: University of California Press, 1997.

Cooper, Frederick, Holt, Thomas and Scott, Rebecca . Beyond Slavery: Explorations of Race, Labor and citizenship in Post Emancipation Societies. Chapel Hill and London: University of North Carolina Press, 2000.

Coupland, Sir Reginald. The British Anti-Slavery Movement. Oxford: Oxford University Press, 1933.

Davis, David Brion. The Problem of Slavery in the Age of Revolution, 1770-1823. Ithaca: Cornell University Press, 1975.

Dilley, Marjorie. British Policy in Kenya. New York: Barnes and Noble, 1966.

Drescher, Seymour. Capitalism and Antislavery: British Mobilization in Comparative Perspective. New York: Oxford University Press, 1987

Foucault, Michel. Discipline and Punish: The Birth of the Prison. Translated by Alan Sheridan. London: Lane, 1977.

Furedi, Frank. The Mau Mau War in Perspective. Athens: Ohio University Press, 1989. 
Green, William. British Slave Emancipation: The Sugar Colonies and the Great Experiment, 1830-1865. Oxford: Clarendon, 1976.

Gregory, Robert C. Sidney Webb and East Africa: Labour's Experiment with the Doctrine of Native Paramountcy. Berkeley: University of California Press, 1962.

Hansen, Holger Bernt. Missions Church and State in a Colonial Setting, Uganda, 1890-1925. New York: St. Martins Press , 1985.

Hodges, Geoffrey. The Carrier Corps: Military Labour in the East African Campaign. Westport: Greenwood Press, 1986.

Holt, Thomas. The Problem of Freedom. Baltimore: Johns Hopkins University Press, 1992.

Hutchinson, W. R. and Christensen, T. Missionary Ideologies in the Imperialist Era. Aarhus, 1982.

Kay, Geoffrey. Development and Underdevelopment: A Marxist Analysis. New York: St. Martin's Press, 1975.

Killingray, David and Rathborn, Richard, eds. Africa and the Second World War. New York: St. Martins Press, 1988.

Klein, Martin., ed. Breaking the Chains: Slavery, Bondage and Emancipation in Modern Africa and Asia. Madison: University of Wisconsin Press, 1993. and Suzanne Miers, eds. Slavery and Colonial Rule In Africa. London: Frank Cass, 1999.

Kloosterboer, Wilemina. Involuntary Labour since the Abolition of Slavery. Leiden. Brill, 1960.

Lee, J. M. Colonial Development and Good Government: A Study of the Ideas Expressed By the British Official Classes in Planning Decolonization 1939-1964. Oxford: Clarendon, 1967.

Leys, Colin. Underdevelopment in Kenya: The Political Economy of Neo-Colonialism. Berkeley: University of California Press, 1974.

Lovejoy, Paul. Unfree Labor in the Development of the Atlantic World. London: Frank Cass 1994.

Lorimer, Douglas. Colour, Class and the Victorians: English Attitudes to the Negro in the Mid-Nineteenth Century. Leicester: Leicester University Press, 1978 
Mackenzie, Fiona. Land, Ecology and Resistance in Kenya, 1880-1952. Portsmouth: Heinemann, 1998.

Mamdani, Mahmood., ed. Ugandan Studies in Labour. Dakar: CODRISIA, 1996.

Mann, Kristen and Roberts, Richard, eds. Law in Colonial Africa. Portsmouth: Heinemann Educational Books, 1991.

Maxon, Robert. Struggle for Kenya: The Loss and Reassertion of Imperial Initiative. London: Associated University Presses, 1993.

. John Ainesworth and the Making of Kenya. Washington: University Press of America, 1980.

. Conflict and Accomodation in Western Kenya: the Gusii and the British, 1907-1963. London: Associated University Press, 1989.

and W. R. Ochieng, eds. An Economic History of Kenya. Nairobi: East African Educational Publishers, 1992.

Mbithi, Philip and Barnes, Carolyn. The Spontaneous Settlement Problem in Kenya. Nairobi: East African Literature Bureau, 1975.

Miers, Suzanne. Britain and the Ending of the Slave Trade. New York: Africana Publishing Co., 1975.

Miles, Robert. Capitalism and Unfree Labour. London and New York: Tavistock Publications, 1987.

Mellor, G. R. British Imperialist Trusteeship, 1783-1850. London: Faber and Faber, 1951.

Moore, Sally Falk. Social Facts and Fabrication: “Customary” Law and Kilimanjaro, 18801980 Cambridge: Cambridge University Press, 1986.

Morton, Fred. Children of Ham: Freed Slaves and Fugitive Slaves on the Kenya Coast, 18731907 Boulder: Westview Press, 1990.

Mosley, Paul. The Settler Economies: Studies in the Economic History of Kenya and Southern Rhodesia. Cambridge: Cambridge University Press, 1983.

Mungeam, G. British Rule in Kenya 1895-1912. Oxford: Clarendon Press, 1966.

Munro, J. Forbes. Colonial Rule and the Kamba: Social Change in the Kenya Highlands 1889-1939. Oxford: Clarendon Press, 1975. 
Nwulia, Moses. Britain and Slavery in East Africa: London: Lynne Rienner Publishers, 1975.

Ogot, Bethwell A, ed. Politics and Nationalism in Kenya. Nairobi: East African Publishing House, 1972.

Olivier, Lord. White Capital and Colored Labor. London: Hogarth Press, 1929.

Odhiambo, E.S. Atieno. Siasa: Politics and Nationalism in East Africa: 1909-1939. Kenya Literature Bureau.

Onselen Van, C. Chibaro: African Mine Labour in Southern Rhodesia, 1900-1933. London: Pluto, 1976.

Palmer, Colin. ed. The Worlds of Unfree Labour: From Indentured Servitude to Slavery. Brookfield: Ashgate Publishing Company, 1998.

Panford, Kwamina. African Labor Relations and Workers Rights: Assessing the Role of The ILO. Westoprt: Greenwood Press, 1994

Phillips, Anne. The Enigma of Colonialism: British Policy in West Africa. London: James Currey LTD, 1989.

Porter, Bernard. Critics of Empire: British Radical Attitudes Towards Colonialism in Africa 1895-1914. New York: St. Martins Press, 1968.

Portes, A. and Walton, J. Labor Class and the International System. New York: Academic Press, 1981.

Powelsland, P. G. Economic Policy and Labour. Kampala: EAISR, 1957.

Robinson, Keneth. The Dilemmas of Trusteeship: Aspects of British Colonial Policy Between the Wars. London: Oxford University Press, 1965.

Robinson, Ronald; Forster, Stig and Mommsen, Wolfgang, eds. Bismarck, Europe and Africa: The Berlin Africa Conference 1884-1885. London: Oxford, 1988.

Ross, William McGregor. Kenya From Within. London: Frank Cass, 1968.

Semmel, Bernard. Imperialism and Social Reform: English Social Imperial Thought. 18951914. New York: Anchor Books, 1968.

Smith, H. Maynard. Frank Bishop of Zanzibar 1811- 1924. New York: The Macmillan Company, 1926. 
Solow, Barbara and Engerman, Stanley., eds. British Capitalism and Caribbean Slavery: The Legacy of Eric Williams. Cambridge: Cambridge University Press, 1987.

Sorrenson, M .P .A. The Origins of European Settlement in Kenya. Nairobi: Oxford University Press, 1968.

Steinfeld, Robert J. Coercion, Contract and Unfree Labor in the $1^{\text {th }}$ Century. New York: Cambridge University Press, 2000.

Stichter, Sharon. Migrant Labour in Kenya: Capitalism and African Response. London: Longman, 1982.

Swainson, Nicola. The Devlopment of Coporate Capitalism in Kenya, 1918-1977. London: 1980.

Temperley, Howard. British Antslavery, 1833-1870. Columbia: University of South Carolina Press, 1972.

Thornton, A. P. The Imperial Idea and its Enemies. London: MacMillan and Co. LTD., 1959.

Tignor, Robert. The Colonial Transformation of Kenya: The Kamba, Kikuyu and Maasai from 1900 to 1939. Princeton: Princeton University Press, 1976.

Twaddle, Michael. The Wages of Slavery: From Chattel Slavery to Wage Labour In Africa, The Carribean and England. London and Portland: Frank Cass, 1993.

Wallerstein, Immanuel. Africa and the Modern World. Trenton: Africa World Press, 1986.

Walvin, James. Questioning Slavery: London: Routledge, 1996.

. Slavery and British Society, 1776-1846. Baton Rouge: Louisiana State University Press, 1982.

Wolf, Richard. The Economics of Colonialism: Britain and Kenya, 1870-1930. New Haven: Yale University Press, 1974.

van Zwanenberg, R. M. A. Colonial Capitalism and Labor in Kenya. Nairobi: East African Literature Bureau, 1975. , with King, Anne. An Economic History of Kenya and Uganda. New Jersey: Humanities Press, 1975.

Zageye, Abebe and Shero, Shubi, eds. Forced Labor and Migration. New York: Hans Zell Publishers, 1989. 


\section{Articles}

Arrighi, Giovanni. "Labour Supplies in Historical Prespective: A Study of the Proletarianization of the African Peasantry in Rhodesia.” Journal of Development Studies 6 (1970): 198233.

Berman, Bruce and Lonsdale, John. "Crises of Accumulation Coercion and the Colonial State: The Development of the Labour Control System in Kenya, 1919-1929." Canadian Journal of African Studies 14(1) (1980): 37-54.

Bernstein, H and Depelchin, J. "The Object of African History," History in Africa 5 (1978): 119; 6 (1979): 17-43.

Books, R. Brenner. "The Origins of Capitalist Development: A Critique of NeoSmithian Marxism.” New Left Review 104 (1977): 25-92.

Buraway, M. "Toward a Marxist Theory of the Labor Process: Braverman and Beyond." Politics and Society 8 (1978): 247-312.

Chauncey, G. “The Locus of Reproduction: Women's Labour in the Zambian Copperbelt, 19271933." Journal of South African Studies 7 (1981): 135-164.

Conklin, Alice. "Colonialism and Human Rights, A Contradiction in Terms? The Case of France and West Africa." American Historical Review 103(2) (1998): 419-442.

Foster-Carter, Aiden. “The Modes of Production Debate.”: New Left Review 107 (1978): 47-73.

Gallagher, John. "Fowell Buxton and the New Africa Policy, 1838-1842." Cambridge Historical Journal 10 (1950): 36-58.

Hunt, Nancy Rose. "Playing African Women's History and Locating Gender.” Signs 14 (1989): 359-79.

Hyam, Ronald. “The Colonial Office Mind, 1900-1914.” Journal of Imperial Commonwealth History 8 (1979): 30-55.

Killingray, David. "Labour Exploitation for Military Campaigns in British Colonial Africa, 1870 1945.” Journal of Contemporary History 24 (1989): 483-501.

Law, Robin. "In Search of A Marxist Perspective on Precolonial Africa." Journal of African History 19 (1978): 451-452.

. "For Marx but with Reservations Althusser: A Comment on Bernstein and Depelchin." History in Africa 8 (1981): 247-57. 
Miers, Suzanne. "Slavery and the Slave Trade as International Issues 1890-1939." Slavery and Abolition 19 (1998): 16-37.

Munro, J. Forbes. "Carrier Recruitment in The British East African Protectorate, 1914-18." Journal of African History 7(2) (1966): .

Newbury, Colin and Gertrude. "Labor Charters and Labor Markets: The ILO and Africa in the Interwar Period.” Journal of African Studies 3 (1976): 311-327.

Nworah, Kenneth. "The Aborigines Protection Society, 1889-1909: A Pressure Group in Colonial Policy.” Canadian Journal of African Studies 5 (1) (1971): 79-91.

. "The Liverpool Sect and British West Africa." African Affairs 10 (October 1971): 349364.

Nwulia, Moses ."The Role of Missionaries in the Emancipation of Slaves in Zanzibar." Journal of Negro History 60(2) (April 1975): 268-287.

Rainger, Ronald. "Philanthropy and Science in the 1830s: The British and Foreign Aborigines Protection Society." Man 15(4) (December 1980): 702-717.

Temperley, Howard. “Capitalism, Slavery and Ideology.” Past and Present 75 (1977): 94-118.

Thomas, Roger. "Forced Labour in British West Africa: The Case of the Northern Territories of The Gold Coast 1906-1927." Journal of African History 14 (1973): 79-103.

Wylie, Diana. "Confrontation Over Kenya: The Colonial Office and Its Critics, 1918-1940." Journal of African History 18 (1977): 427-47.

. " Norman Leys and McGregor Ross: A Case Study in the Conscience of African Empire, 1900-1939.” The Journal of Imperial and Commonwealth History 5 (1977): 294-309. 